UNIVERSIDAD NACIONAL DE LA PLATA

FACULTAD DE CIENCIAS EXACTAS

DEPARTAMENTO CIENCIAS BIOLÓGICAS

\title{
Genómica, proteómica y fisiologia de neuropéptidos en el insecto triatomino Rhodnius prolixus.
}

Oportunidades para el diseño de nuevas estrategias de control de Chagas

Trabajo de Tesis Doctoral

Tesista: WULFF JUAN PEDRO

Directora: ONS SHEILA

Codirector: IANOWSKI JUAN

2018 


\section{RESUMEN}

En Argentina existen aproximadamente 2.300.000 infectados de Chagas. El control del insecto vector continúa siendo la opción más viable como control y prevención de la enfermedad. En las últimas dos décadas se detectó la existencia de poblaciones de triatominos resistentes a insecticidas (Triatoma infestans), en las provincias de Chaco, Salta, y en el Sur de Bolivia. Esto representa un grave riesgo para el control de la enfermedad de Chagas en Argentina y la región.

El presente trabajo utiliza como organismo modelo al triatomino $R$. prolixus. Este insecto reúne una serie de características favorables para su uso como modelo en fisiología de insectos: es el segundo vector más importante de la enfermedad de Chagas; posee características favorables para su cría; se conoce su secuencia genómica; los resultados obtenidos en $R$. prolixus potencialmente pueden aplicarse a otros triatominos, en incluso otros insectos. Particularmente, para estudios de desarrollo post-embrionario como los realizados en este trabajo, una ventaja del modelo es que el ciclo de muda se desencadena de manera predecible tras la ingesta de sangre, lo que permite sincronizar los experimentos.

Este trabajo de Tesis se inscribe en el marco de alcanzar alternativas de control de insectos perjudiciales, que resulten más eficientes, selectivas y seguras para el medio ambiente respecto a los insecticidas neurotóxicos en uso. En éste sentido, se estudian los neuropéptidos, hormonas peptídicas que regulan todos los procesos vitales en organismos multicelulares. El estudio de estas moléculas tiene potencial aplicabilidad para el diseño de insecticidas. Podría permitir el diseño de pseudo-péptidos o péptidomiméticos capaces de interferir con la fisiología de insectos de importancia sanitaria o económica, constituyendo una vía novedosa hacia la obtención de nuevos insecticidas.

Entre los resultados alcanzados en el trabajo, en primer lugar, se identificó una nueva isoforma del gen de orcokininas, codificante para un precursor de neuropéptidos en $R$. prolixus. Esta isoforma, llamada "Orcokinina C" no fue identificada hasta el momento en ninguna otra especie de insectos. Se determinó su secuencia, su estructura molecular y los péptidos maduros generados por clivaje proteolítico. 
Por otro lado se determinó el patrón de expresión en tejidos de las tres isoformas del gen orcokinina en $R$. prolixus (RhoprOKA, RhoprOKB y RhoprOKC). Se completó el patrón de expresión de RhoprOKA en tejidos periféricos y para RhoprOKB en sistema nervioso central y tejidos periféricos por inmunohistoquímica. Se encontró que ambas isoformas se expresan en gónadas, y que RhoprOKB también está presente en intestino medio. RhoprOKC fue detectado únicamente en intestino medio por medio de RT-qPCR.

Por otro lado, se determinó el patrón de expresión temporal de RhoprOKA y RhoprOKB a lo largo de todo el ciclo de muda en ninfas de cuarto estadio. Se observó que tanto OKA como OKB aumentan su expresión hacia final del ciclo de muda día 12 post ingesta (PBM), lo cual es un primer indicio sobre su papel en el proceso de ecdisis, confirmado durante el trabajo por otras aproximaciones.

Se evaluó la relación de las OKs con la síntesis de ecdisteroides mediante dos aproximaciones experimentales: análisis cuantitativo de la expresión de "genes reporteros" ligados a cambios en la concentración de ecdisteroides; y medición directa de la concentración hemocélica de ecdisteroides mediante ELISA competitivo. En conjunto, los resultados apuntan a un papel ecdisteroidostático de la isoforma RhoprOKA.

Se estudió el papel de RhoprOKs por medio de silenciamiento transcripcional mediado por RNA de interferencia. Los resultados confirmaron un papel central de RhoprOKA en la regulación de la ecdisis, y un posible papel contributivo de RhoprOKB en este proceso; los insectos que expresan niveles significativamente reducidos de RhoprOKA fueron incapaces de completar una ecdisis exitosa.

Se estudió el efecto de RhoprOKs sobre la expresión de otros genes relacionados al proceso de ecdisis. El silenciamiento de este gen en ninfas cuarto estadio se correspondió con una disminución en el nivel de expresión de neuropéptidos centrales en la regulación del proceso de muda: ETH: hormona desencadenante de la ecdisis; EH: hormona de la eclosión; CZ: corazonina y CCAP: péptido cardio-acelerador de los crustáceos, medido el día 11 PBM (aproximadamente 1-2 días pre-ecdisis). Se observó que el silenciamiento de la isoforma RhoprOKA produce una disminución de la expresión de los genes RhoprETH y RhoprCCAP, al tiempo que un aumento de la expresión de RhoprEH y RhoprCZ. Este aumento se confirmó en dos días diferentes del 
ciclo de muda: día 6 PBM (durante el pico de ecdisona) y día 11 PBM (justo antes de la ecdisis). El silenciamiento de la isoforma RhoprOKB produjo un efecto más restringido en la expresión de otros genes: una disminución de RhoprCCAP el día y un aumento de RhoprCZ el día 11 PBM.

Se determinó además la expresión de los transcriptos RhoprETH, RhoprEH y RhoprCZ, en ninfa $4^{\text {ta }}$ durante todo el ciclo de muda. Se observó un aumento en el nivel de expresión en los días 6, 10 y 12 PBM para RhoprETH; un aumento en el nivel de expresión en los días 10 y 12 PBM para RhoprEH y un aumento en el nivel de expresión en el día 12 PBM para RhoprCZ. Es la primera vez que se realiza este tipo de análisis en un insecto hemimetábolo. Los patrones de expresión coinciden con lo reportado en la bibliografía para especies holometábolas.

Se realizó el silenciamiento de la expresión de los genes RhoprETH, RhoprEH y RhoprCZ mediante RNA interferencia. Los resultados apuntan a que estos neuropéptidos conforman una red de regulación de la ecdisis, de manera similar a lo reportado para especies holometábolas. Es el primer trabajo en realizar este tipo de análisis en hemimetábolos. Los resultados sugieren que el péptido RhoprCZ estimula la síntesis de RhoprETH (tal como sucede en lepidópteros). Existe por otro lado un ciclo de regulación positiva entre RhoprETH y RhoprEH, observado también en especies holometábolas con la excepción de D. melanogaster. Por ultimo ETH regula la expresión de RhoprCCAP, y RhoprOKA y RhoprOKB.

Se utilizó una preparación in vitro para estudiar la interacción entre orcokininas, ecdisona y neuropéptidos asociados a la regulación de la ecdisis. Los resultados indican que la ecdisona, en determinadas condiciones fisiológicas, estimularía la síntesis de la isoforma RhoprOKA, que a su vez reprimiría la expresión de los genes RhoprCZ, RhoprETH, RhoprEH, RhoprCCAP y la isoforma RhoprOKB. En conjunto, los resultados obtenidos mediante distintas aproximaciones experimentales son coherentes, y sugieren una retroalimentación negativa entre RhoprOKA y la ecdisona; la ecdisona estimula la síntesis de RhoprOKA, lo que a su vez disminuye los niveles circulantes de ecdisona.

Los ensayos in vitro con péptidos sintéticos mostraron que RhoprOKA produjo una disminución en el nivel de expresión de $\mathrm{EH}$ y $\mathrm{CZ}$, coincidente con lo observado en los ensayos de silenciamiento transcripcional. Se observó además una disminución en la 
expresión de RhoprCZ con la adición al medio de RhoprOKB, lo cual es coincidente con resultados obtenidos mediante silenciamiento transcripcional.

En base a todos los resultados obtenidos en el trabajo, en conjunto con antecedentes bibliográficos para otras especies, se sugirió el primer modelo de regulación endócrina del proceso de muda para un insecto hemimetábolo, incluyendo a los cuatros principales neuropéptidos conocidos como reguladores de la muda en insectos holometábolos (ETH, EH, CCAP y CZ), junto con ecdisteroides y orcokininas.

El trabajo de Tesis presentado representa un aporte en la comprensión de la regulación hormonal del proceso de ecdisis en el insecto hemimetábolo R. prolixus, y aporta por primera vez evidencia en cuanto al papel central de los neuropéptidos orcokinina en la regulación de la muda en insectos. Se presenta por primera vez un análisis integral de la función de neuropéptidos reguladores de la ecdisis en un insecto hemimetábolo. Los resultados son relevantes dentro del campo de la entomología básica, y tienen potencial aplicación en el desarrollo de estrategias de control de plagas de insectos basadas en blancos endócrinos. 


\begin{abstract}
In Argentina there are approximately 2,300,000 infected with Chagas. The control of the insect vector continues to be the most viable option as control and prevention of the disease. In the last two decades, the existence of triatomine populations resistant to insecticides (Triatoma infestans) was detected in the provinces of Chaco and Salta, and in the south of Bolivia. This represents a serious risk for the control of Chagas disease in Argentina and the region.

The present work uses as a model organism the triatomine $R$. prolixus. This insect has a series of favorable characteristics for its use as a model in insect physiology: it is the second most important vector of Chagas disease; has favorable characteristics for its breeding; its genomic sequence is known; the results obtained in $R$. prolixus can potentially be applied to other triatomines, in even other insects. Particularly, for studies of post-embryonic development such as those carried out in this work, an advantage of the model is that the molting cycle is triggered in a predictable manner after the ingestion of blood, which allows the experiments to be synchronized.
\end{abstract}

This thesis work falls within the framework of achieving alternatives to control harmful insects that are more efficient, selective and safe for the environment with respect to the neurotoxic insecticides in use. In this sense, we study the neuropeptides, peptide hormones that regulate all vital processes in multicellular organisms. The study of these molecules has potential applicability for the design of insecticides. It could allow the design of pseudo-peptides or peptide-mimetics capable of interfering with the physiology of insects of sanitary or economic importance, constituting a novel route towards obtaining new insecticides.

Among the results achieved in the work, in the first place, a new isoform of the Orcokinins gene was identified, coding for a precursor of neuropeptides in R. prolixus. This isoform, called Orcokinin $\mathrm{C}$ was not identified until now in any other insect species. Its sequence, its molecular structure and the mature peptides generated by proteolytic cleavage were determined. 
On the other hand, the tissue expression pattern of the three isoforms of the Orcokinin gene in $R$. prolixus (RhoprOKA, RhoprOKB and RhoprOKC) was determined. The expression pattern of RhoprOKA in peripheral tissues and for RhoprOKB in the central nervous system and peripheral tissues was completed by immunohistochemistry. It was found that both isoforms are expressed in gonads, and that RhoprOKB is also present in the midgut. RhoprOKC was detected only in the midgut through RT-qPCR.

On the other hand, the pattern of temporal expression of RhoprOKA and RhoprOKB was determined throughout the molting cycle in fourth-stage nymphs. It was observed that both OKA and OKB increase their expression towards the end of the 12 day PBM moult cycle, which is a first indication of their role in the process of ecdysis, confirmed during the work by other approaches.

The relationship of the OKs with the synthesis of ecdisteroides was evaluated by means of two experimental approaches: quantitative analysis of the expression of "reporter genes" linked to changes in the concentration of ecdisteroides; and direct measurement of the hemocelic concentration of ecdysteroids by competitive ELISA. Taken together these results, point to an ecdysteroid-static role for the RhoprOKA isoform.

The role of RhoprOKs was studied by means of gene silencing mediated by RNA interference. The results confirmed a central role of RhoprOKA in the regulation of ecdysis, and a possible contributory role of RhoprOKB in this process. Insects expressing significantly reduced levels of RhoprOKA were unable to complete a successful ecdysis.

The effect of RhoprOKs on the expression of other genes related to the process of ecdysis was studied. The silencing of this gene in fourth-stage nymphs correlated with a decrease in the level of expression of central neuropeptides in the regulation of the molting process (ETH: hormone triggering the ecdysis; $\mathrm{EH}$ : hatching hormone; $\mathrm{CZ}$ : corazonin and CCAP: peptide cardio-accelerator of crustaceans), measured on day 11 PBM (approximately 1-2 days pre-ecdysis). It was observed that the silencing of the RhoprOKA isoform produces a decrease in the expression of the RhoprETH and RhoprCCAP genes, as well as an increase in the expression of RhoprEH and RhoprCZ. This increase was confirmed on two different days of the molting cycle: day 6 post 
intake (during the ecdysone peak) and day 11 PBM (just before the ecdysis) The silencing of the RhoprOKB isoform produced a more restricted effect on the expression of other genes: a decrease in RhoprCCAP on day and an increase in RhoprCZ on day 11 PBM.

The expression of the RhoprETH, RhoprEH and RhoprCZ transcripts was also determined in 4th nymph throughout the moult cycle. An increase in the level of expression was observed on days 6, 10 and 12 PBM for RhoprETH an increase in the level of expression on days 1012 PBM to RhoprEH and an increase in the level of expression on day $12 \mathrm{PBM}$ for RhoprCZ. It is the first time that this type of analysis is carried out in a hemimetabolous insect. The expression patterns coincide with that reported in the literature for holometabola species.

The expression of the RhoprETH, RhoprEH and RhoprCZ genes was silenced by interference RNA. The results suggest that these neuropeptides form a regulatory network for ecdysis, in a similar way to that reported for holometabola species. It is the first work in performing this type of analysis in hemimetabolous. The results suggest that RhoprCZ stimulates the synthesis of RhoprETH (as it happens in Lepidoptera). There is, on the other hand, a cycle of positive regulation between RhoprETH and RhoprEH, also observed in holometabola species with the exception of $D$. melanogaster. Finally, ETH regulates the expression of RhoprCCAP, and RhoprOKA and RhoprOKB.

An in vitro preparation was used to study the interaction between Orcokinins, ecdysone and neuropeptides associated with the regulation of ecdysis. The results indicate that ecdysone, under certain physiological conditions, would stimulate the synthesis of the RhoprOKA isoform, which in turn would repress the expression of the RhoprCZ, RhoprETH, RhoprEH, RhoprCCAP genes and the RhoprOKB isoform. Altogether, the results obtained by different experimental approaches are coherent, and suggest a negative feedback between RhoprOKA and ecdysone: ecdysone stimulates the synthesis of RhoprOKA, which in turn decreases the circulating levels of ecdysone.

In vitro tests with synthetic peptides showed that RhoprOKA produced a decrease in the level of expression of $\mathrm{EH}$ and $\mathrm{CZ}$, coinciding with that observed in the gene silencing assays. A decrease in the expression of RhoprCZ was also observed for 
the addition of RhoprOKB to the medium, which is coincident with results obtained by gene silencing.

Based on all the results obtained in the work, together with bibliographic data for other species, the first model of endocrine regulation of the molting process for a hemimetabolous insect was proposed, including the four main neuropeptides known as moulting regulators in holometabolous insects (ETH, EH, CCAP and CZ), along with ecdisteroides and orcokininas.

The presented thesis work represents a contribution in the understanding of the hormonal regulation of the process of ecdysis in the insect hemimetabolous $R$. prolixus, and provides for the first time evidence regarding the central role of the neuropeptide Orcokinina in the regulation of the moult in insects. We present for the first time an integral analysis of the function of neuropeptides that regulate ecdysis in a hemimethabolous insect. The results are relevant within the field of basic entomology, and have potential application in the development of insect pest control strategies based on endocrine targets. 


\section{ÍNDICE}

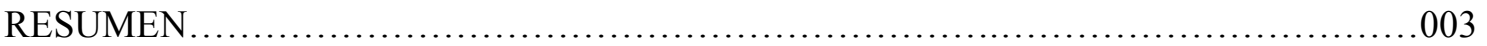

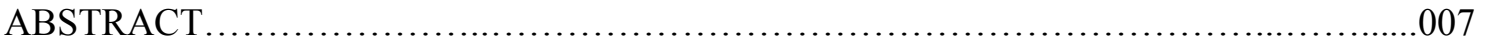

INTRODUCCIÓN GENERAL

1. Neuropéptidos en insectos............................................................

2. R. prolixus como insecto modelo y vector de enfermedad de Chagas....................................020

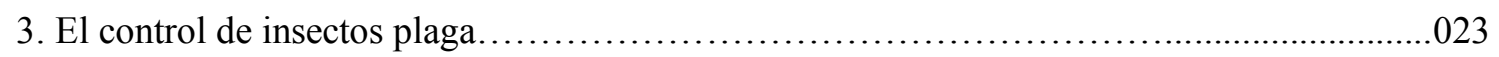

4. El sistema neuroendócrino de insectos como fuente potencial de nuevos blancos de

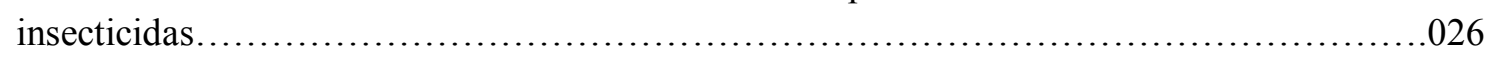

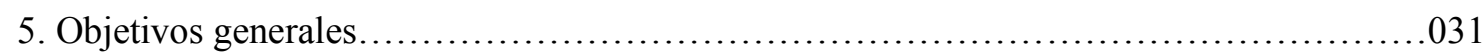

\section{CAPÍTULO I}

"Caracterización del neuropéptido orcokinina en el insecto triatomino Rhodnius prolixus"

1.1. Introducción

1.1.1. Estructura del sistema nervioso en triatominos.....................................033

1.1.2. La orcokinina en insectos................................................. 036

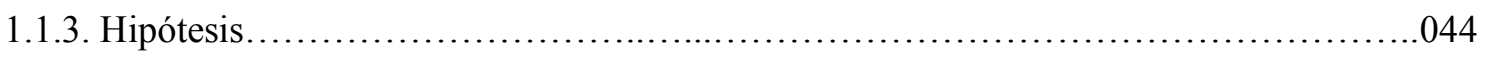

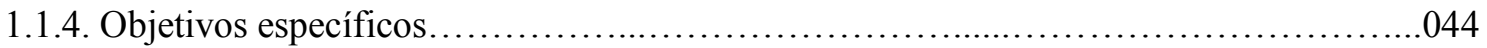

1.2. Materiales y Métodos

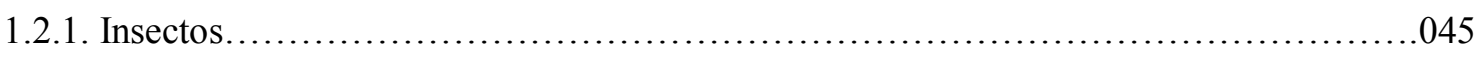

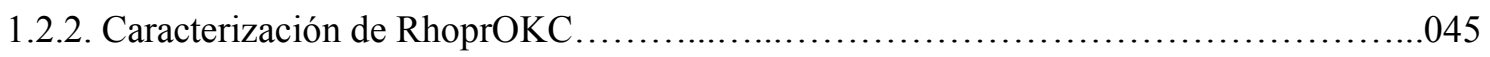

1.2.2.1. Identificación y análisis bioinformático........................................ 045

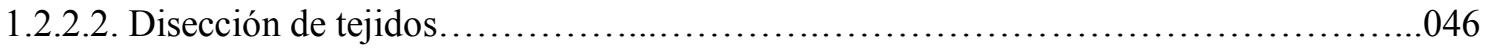

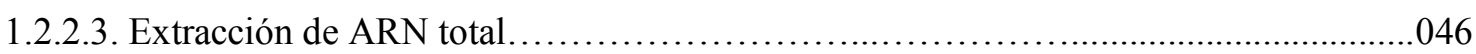

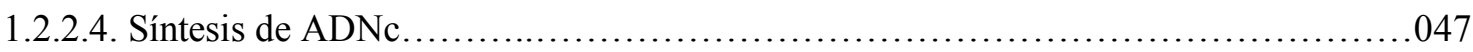

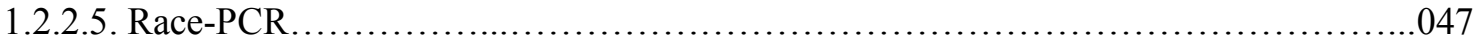

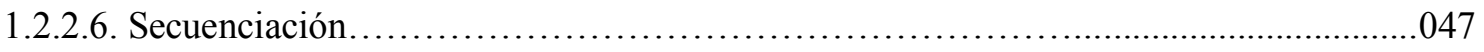

1.2.2.7. Patrón de expresión mediante RT-PCR .......................................... 048 
1.3. Resultados y Discusión

1.3.1. Identificación y caracterización de RhoprOKC .050

1.3.2. Inmunoreactividad para RhoprOKA en tejidos periféricos...........................055

1.3.3. Inmunoreactividad para RhoprOKB/C en SNC y tejidos periféricos.............................059

1.4. Conclusiones. .063

\section{CAPÍTULO II}

"Estudio de la regulación endócrina del ciclo de muda de Rhodnius prolixus"

2.1. Introducción

2.1.1. Ciclo de vida de los insectos .065

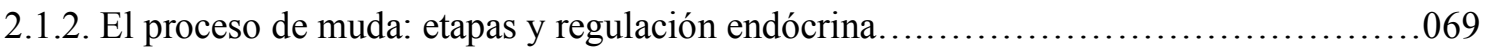

2.1.3. Silenciamiento transcripcional mediante uso de dsRNA ...........................083

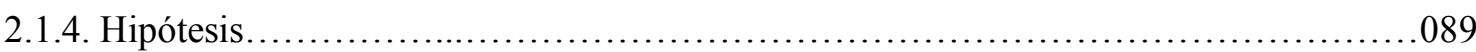

2.1.5. Objetivos específicos...................................................... 089

2.2. Materiales y Métodos

2.2.1. Insectos y disección de tejidos.................................................. 090

2.2.2. Silenciamiento transcripcional mediante uso de dsRNA.............................090

2.2.3. Búsqueda bioinformática de secuencia y diseño de primers...........................091

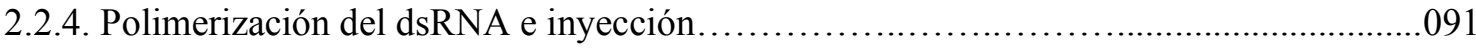

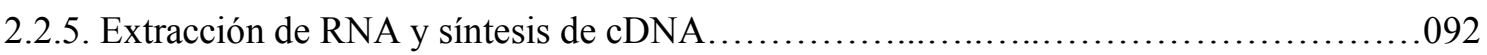

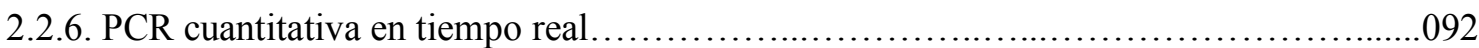

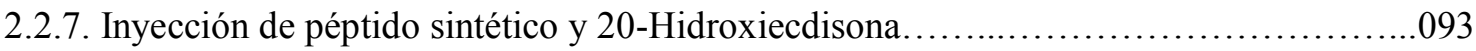

2.2.8. Medición de la concentración de ecdisteroides en hemolinfa por EIA..........................094

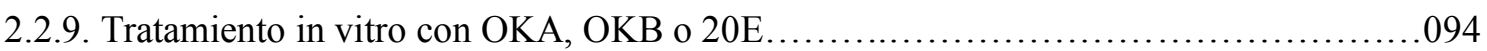

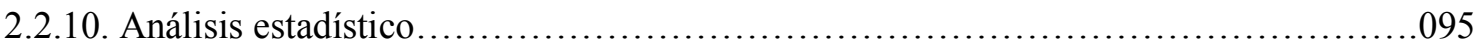

2.3. Resultados y Discusión

2.3.1. Perfil de expresión de RhoprOKA y RhoprOKB en el ciclo de muda.........................096 
2.3.2.1. Análisis del rol funcional de RhoprOKs vía silenciamiento transcripcional (RNAi).

2.3.2.2. Silenciamiento transcripcional de orcokinina discriminando por isoforma (dsOKA y dsOKB)

2.3.3.1. Efecto de dsOKS sobre genes relacionados con la síntesis y liberación de ecdisteroides

2.3.3.2. Efecto de dsOKS sobre la concentración hemocélica de ecdisteroides. 103

2.3.4. Efecto de los ecdisteroides en la expresión de RhoprOKA y RhoprOKB 105

2.3.5. Inyecciones de OKA, OKB y 20E: intento de rescate de la muda en insectos silenciados para RhoprOKs. 106

2.3.5.1. Rescate por inyección de péptido sintético (RhoprOKA y RhoprOKB) 107

2.3.5.2. Inyección de $20 \mathrm{E}$ 108

2.3.6. Papel fisiológico de neuropéptidos reguladores de la muda en insectos 109

2.3.6.1 Perfil de expresión de los neuropéptidos RhoprETH, RhoprEH y RhoprCZ durante el ciclo de muda.

2.3.6.2. Silenciamiento transcripcional RhoprETH, RhoprEH y RhoprCZ.

112

2.3.7.1. Efecto de dsOKS sobre neuropéptidos relacionados con la regulación de la muda.

2.3.7.2. Efecto de dsOKA y dsOKB sobre neuropéptidos relacionados con la regulación de la muda

2.3.7.3. Ensayos in vitro para el estudio del papel de RhoprOKs en la red peptidérgica de regulación de la ecdisis............................................................... 122

2.3.8. Red endócrina que regula el ciclo de muda en $R$. prolixus ..........................127

2.4. Conclusiones.

CONCLUSIONES GENERALES

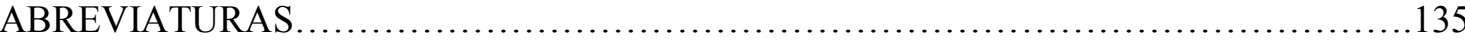

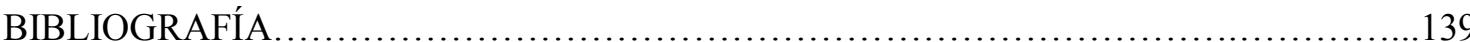

ANEXO

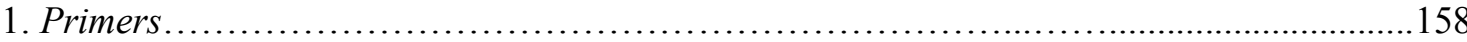

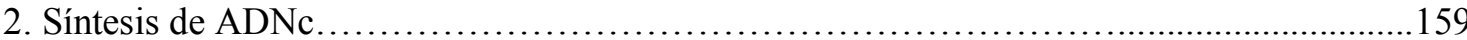

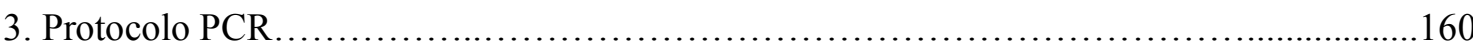




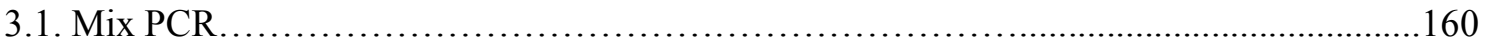

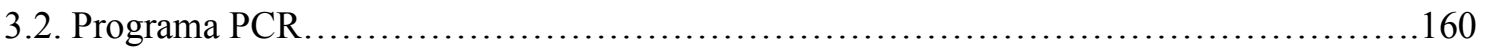

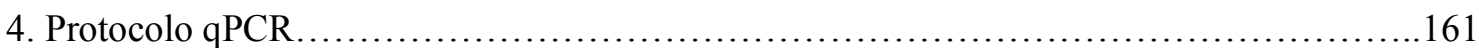

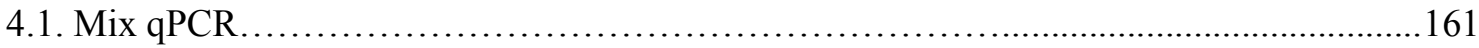

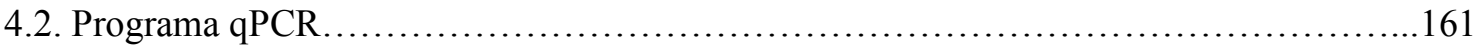

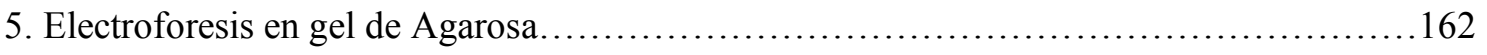

6. Elusión de ADN del gel de agarosa.....................................................162

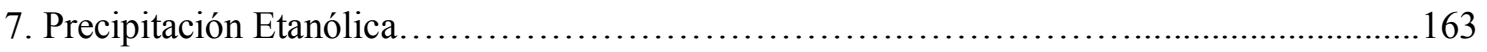

8. Extracción Fenol-cloroformo....................................................... 163

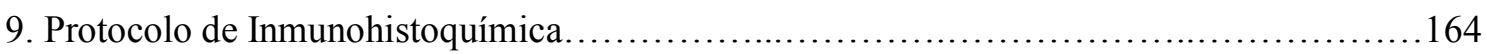

10. Transcripción reversa y síntesis de ARNdc............................................. 165

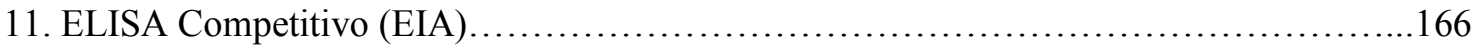

11.1. Procesamiento de las muestras................................................. 167

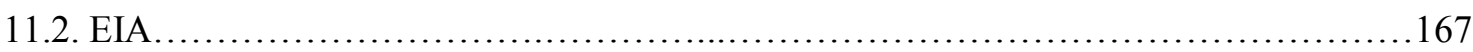

12. Secuencias hormonas de la muda y sitio de unión de los primers utilizados................169

12.1. Secuencia OKs y sitio de unión de primers RNAi por isoforma.......................169

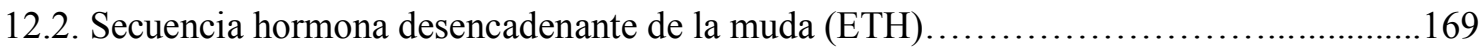

12.3. Secuencia hormona de la eclosión EH...........................................

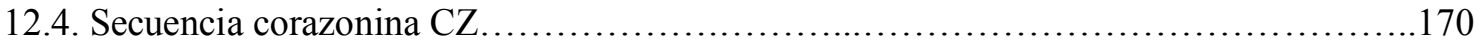

12.5. Secuencia del péptido cardio-acelerador de los crustáceos (CCAP) .....................171

13. Comprobación del silenciamiento transcripcional (caída de transcripto).................171

13.1. Testeo del silenciamiento transcripcional del gen Orcokinina............................171

13.2. Testeo del silenciamiento transcripcional de los neuropéptidos ETH, EH y

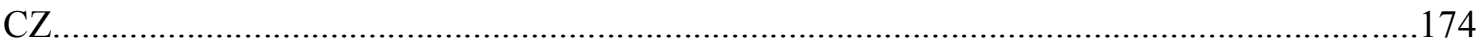

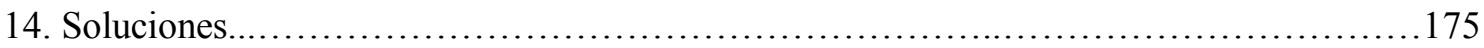

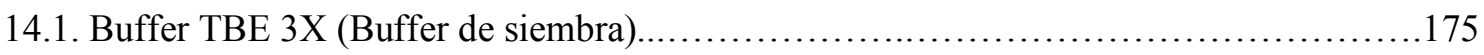




\section{INTRODUCCIÓN GENERAL}

\section{Neuropéptidos en insectos}

Los organismos multicelulares han desarrollado un sistema de comunicación entre células, que permite la coordinación de procesos fisiológicos, y de respuestas frente a estímulos internos o externos (Husak 2015). En los animales, el sistema nervioso central (SNC), el periférico y el sistema endócrino participan en esta coordinación fisiológica. Esta red funciona en forma conjunta y coordinada, emitiendo respuestas inmediatas o dilatadas en el tiempo, determinadas por pulsos eléctricos neuronales conocidos como potencial de acción (PA), y por la liberación puntual de mensajeros químicos. Existen dos grupos principales de mensajeros: los neurotransmisores, que generalmente actúan dentro de la sinapsis nerviosa; y los neuropéptidos, que habitualmente son liberados al hemocele, si bien pueden actuar como neurotransmisores en ciertos casos (Klowden 2013). En insectos particularmente, estos péptidos son liberados a la hemolinfa principalmente a partir de órganos neurohemales tales como la Corpora Cardiaca (CC), nervios abdominales (ABN) proyectados a partir del SNC y distintas proyecciones axonales o glándulas endocrinas ubicadas en distintos tejidos periféricos, como por ejemplo: tráqueas, intestino, cuerpo graso o gónadas. A diferencia de la mayoría de los neurotransmisores, los neuropéptidos se degradan enzimáticamente después de la unión con su receptor (Wilson 2010).

Los neuropéptidos son oligopéptidos producidos y almacenados en vesículas citoplasmáticas ubicadas en terminaciones axonales de neuronas y en células endócrinas, liberados al medio extracelular por exocitosis. En insectos forman parte de la regulación de todos los procesos fisiológicos. Si bien los neuropéptidos pueden ser liberados por células endócrinas en órganos periféricos, su síntesis y liberación se produce en mayor medida en el SNC. Pueden actuar en concentraciones nano molares vía hemocélica, o hasta micro molares, en caso de inervación axonal directa sobre el sitio blanco (como por ejemplo proyecciones nerviosas del ganglio protoráxico (PTG) sobre las glándulas protoráxicas (PG) (Gade 1997; Yamanaka, Roller et al. 2011). 
Los análisis genómicos en insectos llevados a cabo a la fecha, han revelado que existen entre 30 y 40 genes codificantes para precursores de neuropéptidos por genoma (Adams, Celniker et al. 2000; Hewes and Taghert 2001; Riehle, Garczynski et al. 2002; Hummon, Richmond et al. 2006; Li, Predel et al. 2008; Ons, Sterkel et al. 2011; Caers, Boonen et al. 2015). Los genes precursores dan origen a pre-propéptidos, que son modificados post-traduccionalmente para originar los péptidos maduros, biológicamente activos. Las modificaciones más habituales son la eliminación del péptido señal, clivaje proteolítico en sitios dibásicos o monobásicos, y finalmente modificaciones posttraduccionales, de las cuales la más habitual es la amidación C-terminal (Sossin, Fisher et al. 1989; Hallberg 2015).

El péptido señal se ubica en la región $\mathrm{N}$-terminal del precursor, posee una longitud de entre 20 y 30 aminoácidos (Fig. 1) (Nielsen, Engelbrecht et al. 1997). Se compone de tres partes: una región $\mathrm{N}$-terminal de carácter hidrofílico y generalmente con carga positiva; una región central hidrofóbica compuesta por 5-15 aminoácidos y una región C-terminal donde se ubica el sitio de corte de una enzima endopeptidasa. El péptido señal se une a la membrana del retículo endoplasmático, y es la señal que determina la localización de los neuropéptidos en vesículas (Kapp 2000). El primer paso en el procesamiento y maduración del prepropeptido es la eliminación del péptido señal por endopeptidasas (Waugh 2011).

La segunda modificación postraduccional es la escisión del propéptido, vía endopeptidasas, en péptidos más pequeños, habitualmente de entre 10 y 40 aminoácidos. Los péptidos obtenidos por este proceso se han clasificado en dos grupos: aquellos que no están conservados evolutivamente, denominados espaciadores, y aquellos con secuencias conservadas que los agrupan y caracterizan (Fig. 1) (Wegener and Gorbashov 2008). Si bien se asume que la actividad biológica reside en los péptidos conservados (core peptides), casi no existen estudios destinados a conocer la función biológica de los péptidos no conservados, y se ha propuesto un rol estructural dentro del pre-propéptido (Wegener and Gorbashov 2008).

En insectos la escisión de los pre-propéptidos se produce en mayor medida en sitios dibásicos: Arg-Arg, Arg-Lys, Lys-Lys, Lys-Arg. También se registran sitios de corte monobásico, habitualmente en presencia de una Arg, cuando existe un aminoácido básico (Arg, Lys o His) en la posición -4 , -6 o -8 (siendo +1 el residuo situado en el 
extremo C-terminal, y -1 la ubicación del extremo N-terminal del enlace escindible) (Veenstra, Martinovic et al. 2000). Estas predicciones son probabilísticas, si bien se cumplen en un elevado porcentaje de casos no son reglas absolutas.

Por último, luego del clivaje del pre-propéptido, muchos de los neuropéptidos resultantes sufren modificaciones post-traduccionales esenciales para su función fisiológica (Fig. 1). En insectos, la modificación más común es la amidación del extremo C-terminal, que ocurre siempre que existe una Gly en el extremo C-terminal (Sossin, Fisher et al. 1989). Otras modificaciones menos habituales son la oxidación o la adición de un grupo pirofosfato al extremo N-terminal (Sossin, Fisher et al. 1989; Nassel 2002).

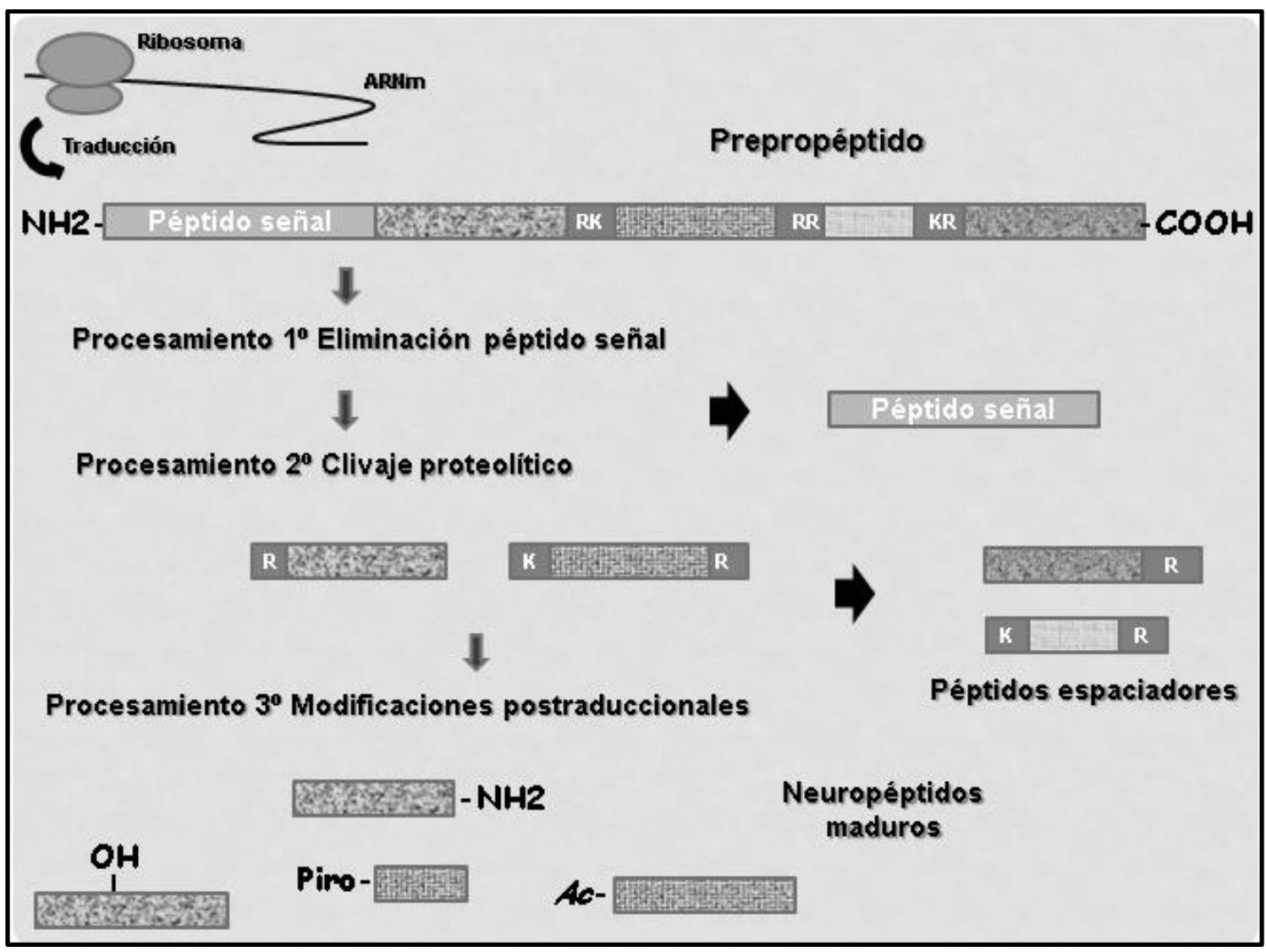

Figura 1: Esquema de la estructura y procesamiento de los neuropéptidos.

La señalización de neuropéptidos ocurre a través de la interacción con receptores presentes en la membrana de la célula target. La mayoría de estos receptores pertenecen 
a la súper familia de receptores de membrana acoplados a proteínas G (GPCRs). Sin embargo, existe un número menor de neuropéptidos que activan receptores tipo tirosina quinasa (ej. el receptor de la hormona protoraxicotrópica (PTTH)), y otros a receptores de tipo guanilato ciclasa (ej. el receptor de la hormona de la eclosión (EH)) (Nassel and Winther 2010).

Los GPCRs constituyen una familia de un elevado número de proteínas. En insectos funcionan como receptores de neuropéptidos, hormonas proteicas y aminas biogénicas, lo que los coloca en un lugar de importancia en la regulación fisiológica (Hauser, Williamson et al. 2006). Existen aproximadamente 50 tipos de genes codificantes para GPCRs de neuropéptidos en insectos. Se han identificado por ejemplo, 37 de estos genes en el genoma de Apis mellifera, 48 en Drosophila melanogaster (Altstein and Nassel 2010) y Tribolium castaneum (Hauser, Cazzamali et al. 2008) y 51 en $R$. prolixus (Ons, Lavore et al. 2016). Un mismo neuropéptido puede activar más de un receptor. Además, cada GPCR puede unirse a diferentes proteínas tipo G, que activan diversas redes de regulación vía distintos segundos mensajeros (ej. $\mathrm{Ca}^{+2}$, AMPc).

Respecto a su estructura, los GPCRs están conformados por siete dominios transmembrana tipo alfa hélice, cada uno integrado por entre 20 y 30 aminoácidos hidrofóbicos. Estos dominios se hayan interconectados por ciclos intra y extra celulares, tres en cada caso. El extremo N-terminal del receptor se ubica en posición extracelular, posee sitios de glicosilacion y es la porción del receptor que interactúa con el ligando (Verlinden 2014). El extremo C-terminal es intracelular, usualmente se encuentra fosforilado e interactúa con proteínas efectoras (proteínas G) (Fig. 2). Las proteínas G se encuentran integradas por tres subunidades: alfa, beta y gamma (Fig. 2). Estas son sometidas a cambios conformacionales en presencia de un ligando, a fin de emitir una respuesta al estímulo. Al interactuar un ligando con el extremo $\mathrm{N}$-terminal del receptor (Fig. 2), se produce un cambio conformacional en el receptor, dando como resultado la unión de la proteína $\mathrm{G}$ al extremo C-terminal citoplasmático del receptor (Fig. 2). Posteriormente, se fosforila un grupo GDP (unido a la proteína G), produciendo guanosin trifosfato (GTP), y esto conduce a la escisión de la subunidad alfa de las dos subunidades restantes. Este proceso desencadena una respuesta a nivel citoplasmático a partir de un segundo mensajero. Finalmente, una vez emitida una respuesta, el GTP es desfoforilado a GDP y la subunidad alfa se ancla nuevamente con las restantes 
subunidades. La proteína $\mathrm{G}$ se libera entonces del receptor y este vuelve a encontrarse en estado activo (Verlinden 2014).

Los GPCRs se clasifican en tres familias, fundamentalmente definidas por tres condiciones: el tipo de ligando al cual se unen, sus cambios en estructura (exceptuando los dominios transmembrana), y los procesos fisiológicos que regulan. La familia A (o Rhodopsin-like) se caracteriza por compartir una cisteína palmitoilada en el extremo Cterminal, lo que provoca una cuarto loop intracelular, la mayoría de los receptores de neuropéptidos pertenece a esta familia (Verlinden 2014). La familia B (o calcitoninlike) se caracteriza por un largo extremo N-terminal, con un número variable de cisteínas (habitualmente 6), formando puentes disulfuro entre sí. Pertenecen a esta familia la mayoría de los receptores para hormonas diuréticas de insectos, tales como calcitonin-like DH y CRF-like DH (Bockaert and Pin 1999). Por último, la familia C, conocida como tipo glutamato metabotrópico, se los identifica por un extremadamente largo extremo N-terminal y un extremo C-terminal también de gran longitud. Estos receptores son activados por ejemplo por glutamato (Verlinden 2014).

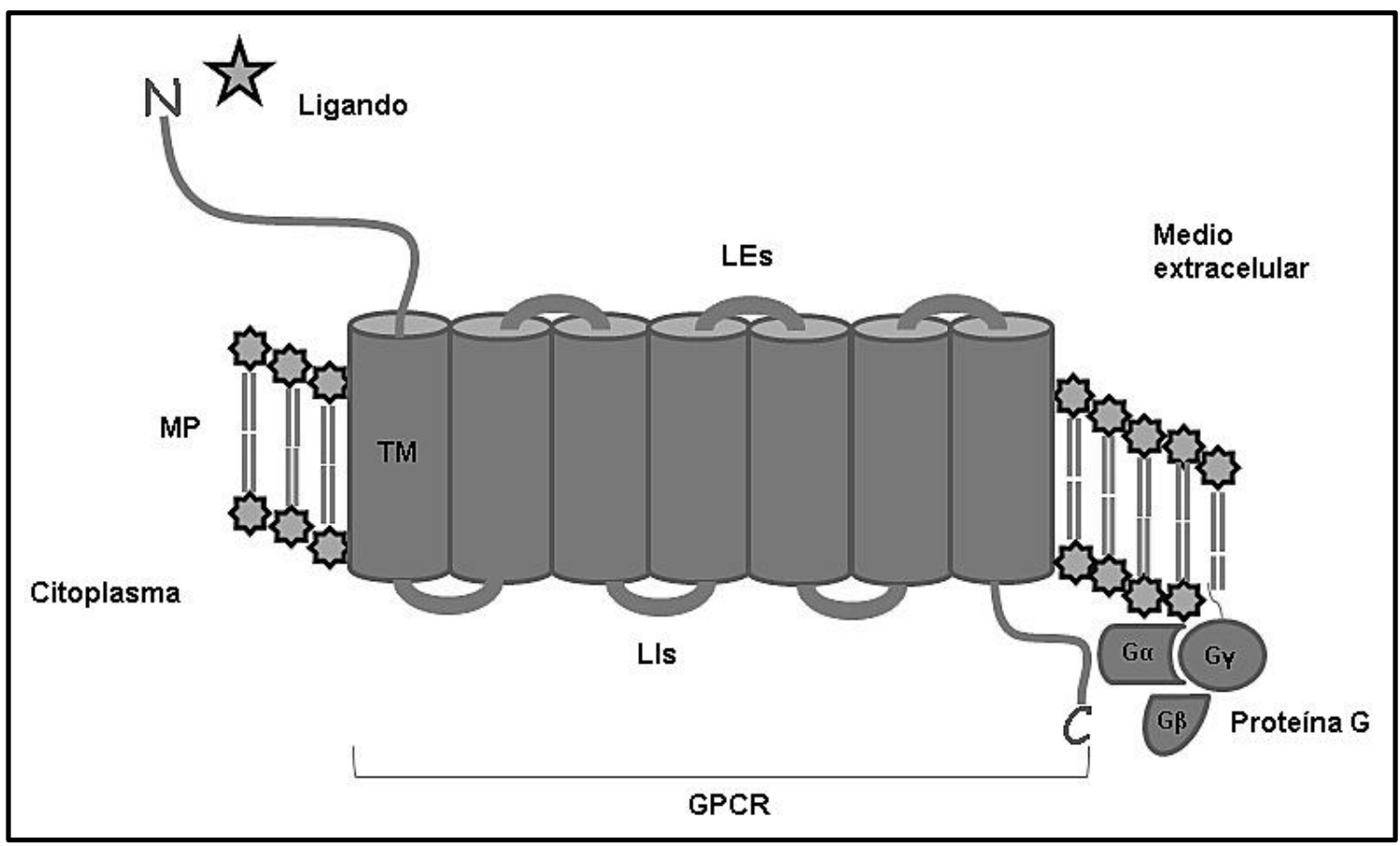

Figura 2: Esquema de la estructura de un GPCR. Membrana plasmática (MP); dominio transmembrana (TM); Loops extracelulares (LEs); Loops intracelulares (LIs); subunidad alfa proteína G (Ga); subunidad beta proteína $\mathrm{G}(\mathrm{G} \beta)$; subunidad gamma proteína $\mathrm{G}(\mathrm{G} \gamma)$. 


\section{Rhodnius prolixus como insecto modelo y vector de enfermedad de Chagas}

Rhodnius prolixus (Hemiptera: Reduviidae) es un insecto hematófago perteneciente a la subfamilia de los triatominos (Stal 1859). Como tal, es capaz de transmitir el protozoario Tripanosoma cruzi, agente etiológico de la enfermedad de Chagas, una enfermedad tropical desatendida (OMS 2017). Los insectos triatominos son conocidos en Argentina como "vinchucas" y en otras regiones como "chipo", "barbeiro", o en inglés "kissing bugs".

La enfermedad de Chagas es endémica de América Latina, si bien se reportan casos en todo el mundo debido principalmente a las migraciones humanas (Rassi, Rassi et al. 2010). Existen actualmente 8 millones de personas infectadas y 10 mil muertes anuales, en mayor medida debido a patologías cardíacas que acontecen en la fase crónica. En Argentina, el número de casos asciende a dos millones (OMS 2017). En América Latina existen alrededor de 25 millones de personas en riesgo de contraer enfermedad de Chagas (OMS 2017).

Las principales especies que vectorizan $T$. cruzi son Triatoma infestans, Triatoma dimidiata, R. prolixus y Panstrongylus megistus (Coura 2000; Miles 2004). T. infestans es la especie con la mayor tasa de contagio, se ubica geográficamente en el centro y norte de Argentina, Paraguay, Bolivia, norte de Chile, sur de Perú y este de Brasil. R. prolixus es el segundo vector más importante de la enfermedad y junto con $T$. dimidiata se distribuyen en países de Centro América y norte de Sudamérica tales como México, Honduras, Guatemala, El Salvador, Panamá, Colombia, Ecuador, Venezuela, ambas Guayanas y norte de Brasil. Finalmente P. megistus sólo se ubica en el centro y este de Brasil, sin embargo dado el elevado riesgo de contagio y densidad poblacional, la tasa de contagio del vector es alta (Coura 2000; Miles 2004; Coura, Vinas et al. 2014).

Si bien $R$. prolixus es susceptible al control con piretroides, aún existen reservorios del insecto en ambientes naturales y peridomiciliarios, donde las campañas de fumigación no han llegado o no se cumplen estrictamente los protocolos de rociado, lo cual explica el alto grado de impacto que aún posee como vector (Dias 2015). Los triatominos son hematófagos obligados durante todo su ciclo de vida, que en este triatomino aproximadamente (en condiciones ideales de laboratorio) tiene una duración de cinco meses desde la eclosión del huevo como N1, hasta alcanzar la etapa adulta. En 
cada evento de alimentación el insecto puede consumir hasta 12 veces su peso (en los primeros estadios y aproximadamente 6 veces en los estadios superiores), lo cual lo obliga a una diuresis rápida (Wigglesworth 1934), durante la cual puede producirse la transmisión de T. cruzi.

Además de su importancia como vector de Chagas, $R$. prolixus ha sido utilizado como modelo para el estudio de la físiología de insectos desde los trabajos pioneros del entomólogo inglés Sir. Vincent Wigglesworth entre las décadas de 1930 y 1960. Utilizando a $R$. prolixus como modelo experimental, Wigglesworth hizo descubrimientos fundamentales sobre el desarrollo, la muda y la reproducción de los insectos (Wigglesworth 1934; Wigglesworth 1940; Wigglesworth 1948; Wigglesworth 1951; Wigglesworth 1964). La especie presenta una serie de ventajas para los ensayos fisiológicos, relacionadas con su tamaño relativamente grande, donde las disecciones y manipulaciones quirúrgicas se pueden realizar con relativa facilidad, y la conveniencia de su cría en insectarios. Además, el desarrollo post-embrionario en triatominos permanece en estado de latencia hasta que el insecto ingiere una cantidad significativa de alimento. La ingesta dispara una serie de procesos fisiológicos que llevan a la muda un número fijo de días después, que varía con cada estadio. Esta característica hace que los experimentos puedan ser precisamente programados y sincronizados (Orchard and Steel 1980; Ampleford and Steel 1982; Garcia 1988; Lee, Orchard et al. 2013; Mansur, Alvarenga et al. 2014; Hamoudi, Lange et al. 2016; Wulff, Sierra et al. 2017).

Algo similar ocurre con los eventos de diuresis y anti-diuresis disparados por la ingesta, que han sido estudiados en profundidad en $R$. prolixus durante décadas (Te Brugge, Miksys et al. 1999; Monteiro, Escalante et al. 2001; Te Brugge, Nassel et al. 2001; Te Brugge and Orchard 2002; Monteiro, Cardoso et al. 2006; Paluzzi and Orchard 2006; Paluzzi, Russell et al. 2008; Ianowski, Paluzzi et al. 2010; Paluzzi and Orchard 2010; Paluzzi, Park et al. 2010; Paluzzi 2012; Paluzzi, Naikkhwah et al. 2012).

La importancia de $R$. prolixus tanto en entomología médica como en estudios fisiológicos motivó, hace más de una década, la conformación de un consorcio científico internacional para secuenciar completamente su genoma a finales del año 2006 (Mesquita, Vionette-Amaral et al. 2015). Este proyecto fue integrado por nuestro grupo de trabajo, junto con otros investigadores de Canadá, EEUU, Brasil, Argentina y Uruguay. Sus conclusiones fueron publicadas recientemente (Mesquita, Vionette- 
Amaral et al. 2015), y la información generada es de libre acceso a la comunidad científica en la web (www.vectorbase.org). Por los motivos expuestos anteriormente, fundamentalmente la disponibilidad de información genómica, la línea de investigación de nuestro grupo de trabajo, dentro de la cual se inscribe la presente Tesis de Doctorado, utiliza como modelo de estudio $R$. prolixus y no T. infestans, que es la especie de mayor importancia como vector de Chagas en el Cono Sur. Debido a la alta conservación de la estructura del sistema neuroendócrino entre estos insectos del mismo orden (Traverso, Sierra et al. 2016), consideramos que los resultados obtenidos son válidos para comprender la regulación endócrina de otros vectores de Chagas. Proponemos además, que $R$. prolixus es un excelente modelo para el estudio del desarrollo post-embrionario en insectos hemimetábolos, dadas las características anteriormente detalladas.

Nuestro grupo de trabajo ha adquirido experiencia en investigaciones realizadas sobre $R$. prolixus, así como otros triatominos, durante los últimos diez años. Inicialmente se identificaron y caracterizaron los genes precursores de neuropéptidos con aproximaciones genómicas, transcriptómicas y proteómicas (Ons, Richter et al. 2009; Ons, Sterkel et al. 2011; Sterkel, Urlaub et al. 2011; Sterkel, Oliveira et al. 2012; Ons, Lavore et al. 2016; Traverso, Sierra et al. 2016; Ons 2017). Mediante uso de peptidómica cuantitativa y transcriptómica se evaluó la respuesta de cada neuropéptido inmediatamente después de una ingesta de sangre (Sterkel, Urlaub et al. 2011; Ons, Lavore et al. 2016), y se determinó el patrón de expresión de un elevado número de neuropéptidos mediante uso de inmunohistoquímica (IHQ) (Ons, Sterkel et al. 2011; Wulff, Sierra et al. 2017). Además, se identificaron y clasificaron los GPCRs de neuropéptidos, aminas biogénicas y opsinas en el genoma de $R$. prolixus y en transcriptomas de otros triatominos (Ons, Lavore et al. 2016). Más recientemente hemos caracterizado los genes precursores de neuropéptidos en transcriptomas de T. infestans, Triatoma pallidipennis y $T$. dimidiata, y hemos comprobado un alto grado de conservación de estos genes entre insectos triatominos (Traverso, Sierra et al. 2016).

Respecto a la caracterización funcional de neuropéptidos, hemos iniciado estudios con aquellos cuyo papel permanece desconocido en insectos. De particular interés para el presente trabajo son los neuropéptidos orcokininas (OKs). Hemos descripto nuevas isoformas de este péptido, altamente conservado en insectos, que está codificada como forma de splicing alternativo por el gen de OKs (Sterkel, Oliveira et al. 
2012). Nuestros resultados, presentados más adelante en detalle, revelan un papel de OKs en la regulación endócrina de la ecdisis en R. prolixus (Wulff, Sierra et al. 2017).

\section{El control de insectos plaga}

Los insecticidas son compuestos químicos utilizados para controlar insectos asociados a problemáticas sanitarias, pérdidas económicas, etc. Su origen se remonta a la Edad Antigua donde se hace mención del uso de elementos como el azufre, arsénico o incluso flores secas de crisantemos (Chrysanthemum cinerariaefolium) como medios de control de plagas (Smith and Secoy 1975). Sin embargo, su estudio desde un enfoque científico tuvo lugar a partir del Siglo XVI, y posteriormente, a nivel molecular a partir del siglo XIX. Las primeras sustancias analizadas fueron derivados vegetales o elementos orgánicos e inorgánicos obtenidos del sustrato (Smith and Secoy 1975; Smith and Secoy 1976). Entre los primeros podemos mencionar la nicotina proveniente del tabaco, piretrinas del crisantemo, o la rotenona obtenida a partir de la raíz de leguminosas tropicales. En simultáneo se testearon compuestos orgánicos tales como derivados del petróleo e inorgánicos, como varios tipos de sulfuro, arsénico, cianuro o el fluoruro de aluminio y sodio conocido como criolita (Thomson 2001). Hacia fines del Siglo XIX y comienzos del XX dio inicio el perfeccionamiento de los insecticidas modernos neurotóxicos, sobre todo aquellos pertenecientes a los grupos de organofosforados, carbamatos (ambos inhibidores de la enzima acetilcolinesterasa) y organoclorados (antagonistas del neurotransmisor GABA).

A partir de la Segunda Guerra mundial (1939) aumentó exponencialmente el uso de los insecticidas, en mayor medida debido a la implementación en programas sanitarios. Se destacan entre los más utilizados los organoclorados como el DDT (dicloro difenil tricloroetano), dieldrin y aldrin, asociados habitualmente a programas destinados al control de insectos vectores de enfermedades tales como Malaria, Fiebre Amarilla y Tifus (Delaplane 2000). Por otra parte, los organofosforados como el TEPP, paratión, fenitrotión, que en mayor medida se asociaban a actividades agrícolas, fueron utilizados intensamente en las décadas de 1940 y 1950 (Wessels 2012). Muchos de ellos, como el TEPP y el DDT, fueron prohibidos en años posteriores por su alta toxicidad para vertebrados, o su alta tasa de persistencia en el ambiente y la fijación en la cadena alimentaria (Delaplane 2000; EPA 2017). 
En simultáneo a la prohibición de los insecticidas más tóxicos y persistentes en el medio ambiente, surgió un problema adicional. Debido al uso masivo, se detectaron cada vez más casos de resistencia en todos los órdenes de insectos (Brown 1958; Brown 1958; Micks 1960). Hacia la década de 1970 comenzó el descubrimiento y/o rediseño de nuevos grupos de insecticidas, entre los que se destacaban los piretroides (interferentes del canal de sodio dependiente de voltaje), los neonicotinoides y spinosad (miméticos de la acetilcolina), las avermectinas y fenilpirazoles (agonistas y antagonistas del GABA respectivamente), y nuevos derivados de organofosforados y carbamatos parcialmente eficientes (Brown 1969; Brown and Pal 1971; Brown 1986; Oberemok, Zaitsev et al. 2015). Esta práctica con el tiempo condujo a crecientes grados de resistencia por especie y la aparición de nuevas poblaciones resistentes. Por otro lado, existe un aumento constante de insecticidas obsoletos y concentraciones de trabajo cada vez mayores, con el elevado riesgo que esto representa sobre los organismos no destinados a ser controlados por el agente tóxico, como por ejemplo polinizadores y otras especies benéficas (Al Naggar, Codling et al. 2015; Codling, Naggar et al. 2017).

Inicialmente los insecticidas más utilizados en el control de triatominos fueron del tipo carbamatos y organofosforados como el malation. Sin embargo a partir de la década de 1980 los programas sanitarios se centraron principalmente en el uso de piretroides, por su alta tasa de eficacia y baja residualidad ambiental (Pessoa, Obara et al. 2015). A partir de la década de 2000 comenzaron a detectarse altas tasas de resistencia a piretroides por parte de poblaciones de $T$. infestans de la provincia argentina de Salta y el sur de Bolivia, tanto en las campañas de fumigación a campo como en ensayos de laboratorio (Picollo, Vassena et al. 2005). Posteriormente se encontraron también focos de alta resistencia en la provincia argentina de Chaco (Capriotti, Mougabure-Cueto et al. 2014; Carvajal, Picollo et al. 2014). En algunos casos se detectó una tasa de resistencia ( $\mathrm{RR}$, del inglés resistance ratio) entre $500 \mathrm{y}$ 1000 veces superior respecto a insectos sensibles (Lardeux, Depickere et al. 2010; Capriotti, Mougabure-Cueto et al. 2014; Sierra, Capriotti et al. 2016).

La resistencia a insecticidas puede provocarse por distintos mecanismos, que se clasifican en resistencia por modificaciones en el sitio de acción, resistencia metabólica, por penetración y por comportamiento (Milani 1957; Tsukamoto 1964; Brown 1969; Oppenoorth 1971; Sawicki 1975). Las modificaciones en el sitio blanco de un insecticida se dan como consecuencia de una mutación que se fija en la población, 
debido a la presión de selección ejercida por el insecticida. Dicha mutación implica una pérdida de afinidad entre el insecticida y su sitio de acción. Un ejemplo de este tipo de resistencia son las mutaciones de tipo $k d r$ (del inglés Knockdown resistance); mutaciones puntuales producen un cambio aminoacídico en el canal de sodio dependiente de voltaje, y como resultado la pérdida de afinidad entre el insecticida y el lugar de acción (Zlotkin 1999; Brooke 2008; Boyer, Zhang et al. 2012). Este tipo de resistencia ha sido caracterizada como la principal causa de resistencia a piretroides detectada en poblaciones de $T$. infestans de la ecoregión del Gran Chaco argentino y boliviano (Fabro, Sterkel et al. 2012; Capriotti, Mougabure-Cueto et al. 2014; Sierra, Capriotti et al. 2016).

El segundo mecanismo de resistencia es el más representado y diversificado entre los insectos y consiste en la detoxificación metabólica del insecticida mediada por acción enzimática. Este proceso se explica en tres eventos moleculares principales: secuestro de la molécula, modificación y excreción del compuesto tóxico. Esta serie de acciones son desarrolladas por enzimas clasificadas dentro de tres grandes grupos: citocromo P450s, carboxil-esterasas y glutatión-S transferasas. Existen antecedentes de que enzimas pertenecientes a las tres categorías participan en la detoxificación de compuestos xenobióticos hacia metabolitos secundarios. Sin embargo, las citocromo P450s y carboxil-esterasas se caracterizan por la inactivación molecular de los insecticidas, ya sea por mono-oxidación en el caso de las P450s o la hidrolisis de enlaces éster en el caso de las esterasas (Oppenoorth 1971; Devonshire 1991; Berge, Feyereisen et al. 1998; Adamo 2004; Hardstone, Strycharz et al. 2015). Por otro lado, enzimas del tipo glutatión-S transferasas se relacionan en mayor medida con la marcación molecular de aquellos compuestos que deben ser procesados por otras enzimas, ya sea con el fin de vacuolizar, excretar, oxidar, transportar, etc. (Lalah, Chien et al. 1995; Enayati, Ranson et al. 2005; Kristensen 2005; Pavlidi, Tseliou et al. 2015). En T. infestans se ha comprobado un aumento en la expresión de genes de enzimas de la familia de P450 en poblaciones resistentes a insecticidas piretroides (Pedrini, Zhang et al. 2010; Grosso, Blariza et al. 2016; Calderon-Fernandez, Moriconi et al. 2017; Traverso, Lavore et al. 2017).

Otro mecanismo de resistencia a insecticidas consiste en una disminución en la penetración del agente toxico por la cutícula. La absorción del insecticida se encuentra disminuida por el engrosamiento de la cutícula, y por cambios en el número de átomos 
de carbono y las ramificaciones presentes en los hidrocarburos cuticulares (CalderonFernandez, Girotti et al. 2012; Balabanidou, Kampouraki et al. 2016). Este mecanismo de resistencia funciona en forma conjunta a la resistencia por detoxificación metabólica debido a dos razones principales. Por un lado, enzimas del tipo citocromo P450s responsables de la síntesis de hidrocarburos cuticulares constituyen la primera barrera detoxificativa. En segundo lugar, la disminución en el contenido total de insecticida que ingresa al organismo favorece la acción enzimática detoxificativa del compuesto, evitando la saturación del sistema (Lalah, Chien et al. 1995; Pavlidi, Tseliou et al. 2015; Balabanidou, Kampouraki et al. 2016). Este tipo de interacción entre grosor cuticular y tasa de resistencia ha sido observado también en poblaciones de $T$. infestans resistentes a piretroides (Pedrini, Mijailovsky et al. 2009).

Finalmente el cuarto mecanismo consiste en un cambio comportamental frente a la presencia del insecticida. El insecto evita activamente un área donde detecta la presencia de un compuesto tóxico, o no se alimenta de un recurso donde detecta la presencia del agente insecticida, sin embargo este método de resistencia es discutido (Zalucki and Furlong 2017).

\section{El sistema neuroendócrino de insectos como fuente potencial de nuevos blancos de insecticidas}

Los neuropéptidos forman parte de todos los procesos fisiológicos que suceden en un insecto. Sucesos tan diversos como la reproducción, desarrollo, muda, osmorregulación, e incluso la contracción muscular de tipo locomotora o visceral son sincronizados por estas moléculas mensajeras (Gade 1997). A partir de la década de 1990, se incrementó el número de publicaciones científicas señalando a los neuropéptidos y sus receptores, como potenciales target para el diseño de nuevos insecticidas, denominados peudopéptidos o peptidomiméticos (Nachman, Holman et al. 1991; Lange, Orchard et al. 1995; Nachman, Roberts et al. 1995; Nachman, Fehrentz et al. 2007; Nachman, Pietrantonio et al. 2009; Nachman, Ben Aziz et al. 2010; Lange, Nachman et al. 2016). La secuenciación de genomas de insectos durante la última década, como el caso de D. melanogaster, A. mellifera o $R$. prolixus, favoreció el estudio de neuropéptidos y sus receptores (Adams, Celniker et al. 2000; Hummon, Richmond et al. 2006; Ons, Sterkel et al. 2011). Actualmente, existe numerosos trabajos 
relacionados con el estudio y caracterización de GPCRs (receptores de un gran número de ligandos, entre éstos neuropéptidos y aminas biogénicas) en insectos (Richards, Gibbs et al. 2008; Tanaka, Suetsugu et al. 2014; Audsley and Down 2015; Miao and McCammon 2016; Ons, Lavore et al. 2016). En la industria farmacéutica, desde hace más de tres décadas, entre el $40-50 \%$ de las drogas de consumo humano utilizadas, actúan sobre receptores tipo proteína G (Garland 2013).

Los insecticidas neurotóxicos de mayor uso en la actualidad (ej. piretroides, organofosforados, carbamatos y neonicotinoides) actúan sólo sobre cuatro de los 28 targets de acción insecticida, descriptos por el comité de acción sobre la resistencia a insecticidas (IRAC 2015). Como agravante además, existen elevado costo ambiental en su uso: 1) elevadas tasas de persistencia en el ambiente y fijación en la cadena alimentaria, como por ejemplo sucede para el DDT (Micks, Ferguson et al. 1960; Casida and Durkin 2013); 2) alta toxicidad para vertebrados como el TEPP (Klendshoj, Moran et al. 1952; Leach 1953; Lewis, McKeon et al. 1955; Kleinfeld, Magin et al. 1960); 3) acción perjudicial sobre insectos benéficos tales como las abejas, como sucede con los neonicotinoides (Casida 2009; du Rand, Smit et al. 2015; Wu-Smart and Spivak 2016); 4) contaminación de cuerpos de agua (Micks 1960; Micks, Ferguson et al. 1960; Casida and Durkin 2013); 5) desarrollo de elevadas tasas de resistencia por mecanismos detoxificativos o mutación de sitio target (Milani 1957; Tsukamoto 1964; Brown 1969; Oppenoorth 1971; Sawicki 1975). Estos antecedentes refuerzan la necesidad de una búsqueda de alternativas en la estrategia del control de plagas.

Un peptidomimético es un compuesto análogo a una molécula endógena, que tiene la capacidad de interactuar con el receptor. La interacción con el receptor suscita una respuesta agónica o antagónica respecto de la molécula endógena original, deprimiendo o incrementado una vía de regulación endócrina (Colborn, vom Saal et al. 1993; Colborn 2004; Colborn 2004). Estos compuestos, pueden o no ser oligopéptidos. De hecho generalmente, las sustancias testeadas al momento son compuestos que interactúan con receptores hormonales, pero que poseen mayor resistencia a los factores físicos y bioquímicos del ambiente. El bencetonio clorhídrico, la diazilhidracina y el pyriproxifen son ejemplos de estos compuestos. Son moléculas de naturaleza no peptídica, antagónicas de la miosupresina, la ecdisona (E) y la hormona juvenil (JH) respectivamente (Patterson and Schwarz 1977; Lange, Orchard et al. 1995; Puricelli 2016). 
Existen distintos tipos de hormonas además de los neuropéptidos. La E y JH son de tipo esteroide y sesquiterpeno respectivamente, las hormonas denominadas aminas biogénicas como la serotonina, u hormonas derivadas de ácidos grasos como la prostaglandina. Sin embargo, la extensa mayoría son oligopéptidos de estructura simple, con algunas excepciones como el bursicon, el cual es una proteína heterodimérica (Truman 1973; Klowden 2013). Además, como se indicó con anterioridad, existen aproximadamente entre 40 y 50 genes codificantes de neuropéptidos y GPCRs respectivamente (Adams, Celniker et al. 2000; Hewes and Taghert 2001; Riehle, Garczynski et al. 2002; Hummon, Richmond et al. 2006; Hauser, Cazzamali et al. 2008; Li, Predel et al. 2008; Altstein and Nassel 2010; Ons, Sterkel et al. 2011). Estos números en conjunto representan un enorme potencial para el estudio y desarrollo de nuevos insecticidas.

Los peptidomiméticos como potenciales agentes de control de plagas ofrecen una serie de ventajas frente a los insecticidas neurotóxicos en uso. En primer lugar, los compuestos basados en moléculas endógenas, teóricamente poseen menor grado de probabilidad de ser identificados como compuestos xenobióticos por mecanismos de detoxificación enzimática. Por otro lado, dada la centralidad de los neuropéptidos en la regulación de los procesos fisiológicos, se propone que estos compuestos serían menos propensos a generar resistencia por mutaciones en el sitio de acción. Esto se debe a que mutaciones en un receptor de neuropéptidos afectarían tanto a la interacción con el pseudopéptido como al ligando endógeno original, y serían por lo tanto deletéreas para los individuos portadores. Finalmente, se trataría de insecticidas especie-específicos (teóricamente inocuos para organismos benéficos) y biodegradables, lo cual los hace ambientalmente sostenibles (Altstein and Nassel 2010).

En Argentina, actualmente se utilizan numerosos compuestos comerciales con acción insecticida análoga a los peptidomiméticos, cuyo mecanismo de acción es desconocido o parcialmente conocido. Podemos citar por ejemplo: 1) el pymetrozine, que actúa sobre los órganos cordotonales, relacionados con la percepción de estímulos físicos sobre la cutícula, del cual no se conoce la proteína blanco; 2) la ciromazina (derivado de la triazina), que inhibe la síntesis de quitina pero no se conoce el sitio de acción; 3) las benzoilureas, inhiben la quitina sintasa y el buprofezin (derivado de tiadiazinona) que afecta esta enzima y de forma indirecta la acetil colinesterasa, pero se desconoce cómo produce dicho efecto; 4) finalmente, el amitraz, agónico de la 
octopamina, se une a su receptor de tipo GPCR, pero no se ha caracterizado en profundidad su efecto sobre otros organismos no blanco (Puricelli 2016). Se han reportado además para este compuesto efectos adversos sobre la síntesis de progesterona en células luteínicas de roedores y humanos (Young, Menadue et al. 2005; Woodward 2012). Por último, existen reguladores de crecimiento (IGRs, del inglés insect growth regulator), compuestos antagónicos de 20E y JH. Se comercializa por ej. la diacilhidrazina que se une al receptor de ecdisteroides, y por otro lado, el metopreno y el pyriproxifen que son antagónicos de $\mathrm{JH}$, pero los tres compuestos poseen un rango de acción inespecífico, en el mejor de los casos sólo restringidos a nivel de orden. Incluso existen compuestos de venta libre como el clofentezine y hexitiazox, inhibidores de crecimiento en ácaros, de mecanismo de acción desconocido y alto poder residual, de hasta 45 días de duración (Puricelli 2016).

De los compuestos anteriormente mencionados ninguno es un oligopéptido, sin embargo, varios de ellos actúan a través de GPCRs, como por ejemplo el amitraz. Es de alta relevancia el estudio de nuevos compuestos insecticidas como alternativa de los convencionales insecticidas neurotóxicos, así como el estudio en profundidad de los mecanismos de acción de compuestos actualmente en el mercado, cuyos efectos secundarios sobre el entorno se desconocen.

Con respecto a los neuropéptidos, se han reportado numerosos ensayos funcionales exitosos que podrían derivar en compuestos con actividad insecticida, aunque todos ellos están en fase experimental. Han sido testeados neuropéptidos osmoreguladores como la kinina, reguladores de crecimiento, o incluso reguladores de la actividad miotrópica como la hormona miosupresina (Lange, Orchard et al. 1995; Nachman, Olender et al. 1996; Kostyukovsky, Chen et al. 2000; Kaczmarek, Williams et al. 2007; Nachman, Kaczmarek et al. 2012; Suman, Brey et al. 2013; Suman, Wang et al. 2013; Leander, Bass et al. 2015; Zels, Dillen et al. 2015; Sterkel, Riccillo et al. 2010).

A modo de ejemplo, en el trabajo realizado sobre el receptor de miosupresina en D. melanogaster y R. prolixus (Leander, Bass et al. 2015), en el cual hemos participado como autores, se estudió el efecto de este péptido y una serie de análogos sobre la reducción de la tasa de contracción de la aorta e intestino. Se analizó en ambos insectos, una serie de análogos de la miosupresina con un número variable de aminoácidos 
faltantes en la región N-terminal. Por este medio, utilizando ensayos in vitro de contracción de tejidos, en forma aislada y en conjunto, se determinó el efecto agónico o antagónico de cada análogo, y el active core aminoacídico de la miosupresina de cada especie y sobre cada tejido. Finalmente, se caracterizó la naturaleza molecular de la unión del péptido con su receptor en ambas especies (tipo GPCR símil rodopsina), lo que se denomina relación estructura-actividad (SAR; del inglés structure-activity relationship). En base a los resultados y un estudio de docking (estudio de la interacción a nivel molecular entre ligando y receptor), y la cristalografía (estudio tridimensional de la estructura cuaternaria de una proteína) de cada receptor, se determinaron los aminoácidos fundamentales en la interacción entre cada péptido y su receptor. Se caracterizó además un nuevo tipo de puente iónico, un puente iónico de tipo 3-6 no identificado hasta la fecha, y un interruptor tipo tirosina quinasa, todos esenciales en la unión de péptido-receptor (Leander, Bass et al. 2015).

Sin bien existe un gran número de publicaciones sobre neuropéptidos, el diseño de bioinsecticidas basados en estas moléculas requiere un enfoque particular. En este sentido, se hace especial hincapié en el estudio de tipo SAR de cada neuropéptido y de su receptor (Altstein and Nassel 2010). El desafío de obtener peptidomiméticos requiere del diseño y perfeccionamiento de técnicas y métodos de trabajo para el testeo de la actividad funcional de cada neuropéptido, y una selección eficaz de los posibles agonistas y antagonistas de sus receptores (Altstein and Nassel 2010). Pocos trabajos analizan en forma completa la actividad selectiva de agonistas o antagonistas en la activación o inhibición de receptores de neuropéptidos, su grado de degradación en el ambiente, el posible efecto secundario sobre otros organismos o la tasa de penetración cuticular, y de la membrana plasmática (Nachman, Roberts et al. 1995; Leander, Bass et al. 2015). Este enfoque multidisciplinario es indispensable para el traspaso de paradigma de los ensayos en laboratorio, a un escenario futuro donde se pueda testear distintos compuestos en ensayos de campo. Como paso inicial de todo el proceso, es fundamental conseguir una comprensión cabal del papel fisiológico de los neuropéptidos. En particular, resulta interesante estudiar los neuropéptidos reguladores de procesos que no existen en vertebrados, tal como por ejemplo la ecdisis, a fin de identificar compuestos que potencialmente sean más seguros para mamíferos. 


\section{Objetivos generales}

El objetivo del presente trabajo es profundizar en la comprensión de la regulación neuropeptidérgica en insectos, utilizando como modelo a Rhodnius prolixus. En particular, nos interesa caracterizar el papel de neuropéptidos relacionados con la regulación de la ecdisis en insectos hemimetábolos. Este proceso es central en la supervivencia de los insectos, al mismo nivel de otros tales como el procesamiento del alimento, la diuresis o la reproducción, por lo cual las moléculas que lo regulan son blancos potenciales para el diseño de insecticidas potencialmente seguros para vertebrados.

Sin embargo, la regulación de la ecdisis sólo ha sido estudiada en profundidad en insectos holometábolos, que poseen un tipo de desarrollo radicalmente distinto a los hemimetábolos. El primer paso en este sentido, es caracterizar la función de cada elemento dentro de este mecanismo de muda, y sobre estos resultados, sentar las bases para entender la red que regula todo la ecdisis en hemimetábolos. 


\section{CAPITULO I}

\section{Caracterización del neuropéptido orcokinina en el insecto triatomino Rhodnius prolixus}

\subsection{INTRODUCCIÓN}

\subsubsection{Estructura del sistema nervioso en triatominos}

En base a observaciones filogenéticas, se propone que el esquema ancestral del sistema nervioso central de los insectos está compuesto de un cordón nervioso doble ventro-sagital, con un par de ganglios en cada segmento (originalmente 12) (Fig. 1.1 A). Estos ganglios consisten en tres masas ganglionares que constituyen el cerebro, un ganglio subesofágico (SOG; del inglés subesophagic ganglia), habitualmente tres ganglios torácicos y ocho ganglios abdominales (Fig. 1.2 A). El cerebro se divide en tres pares de lóbulos o ganglios fusionados: el protocerebro, el deutocerebro y el tritocerebro. El protocerebro inerva los ojos compuestos, los ocelos y la corpora cardiaca (CC); el deutocerebro las antenas y el tritocerebro inerva el labro y el estomodeo. Por otro lado, el ganglio subesofágico inerva las mandíbulas, maxilas, labio, conducto salival y también tiene control sobre la CC. Por último, los nervios que se desprenden de los ganglios torácicos y abdominales inervan las patas, antenas y los distintos órganos (Wilson 2010).

En muchos órdenes de insectos los ganglios han sufrido un proceso de fusión a lo largo de la evolución. En el caso de los hemípteros solo se destacan tres masas ganglionares: el SOG, el ganglio protoráxico (PTG; del inglés prothoracic ganglia) y la masa ganglionar meso-metatorácica (MTGM; del inglés mesometathoracic ganglia mass). Esta última es el resultado de la fusión de los ganglios meso y metatoraxicos, y los ganglios abdominales (Fig. 1.1 B). 


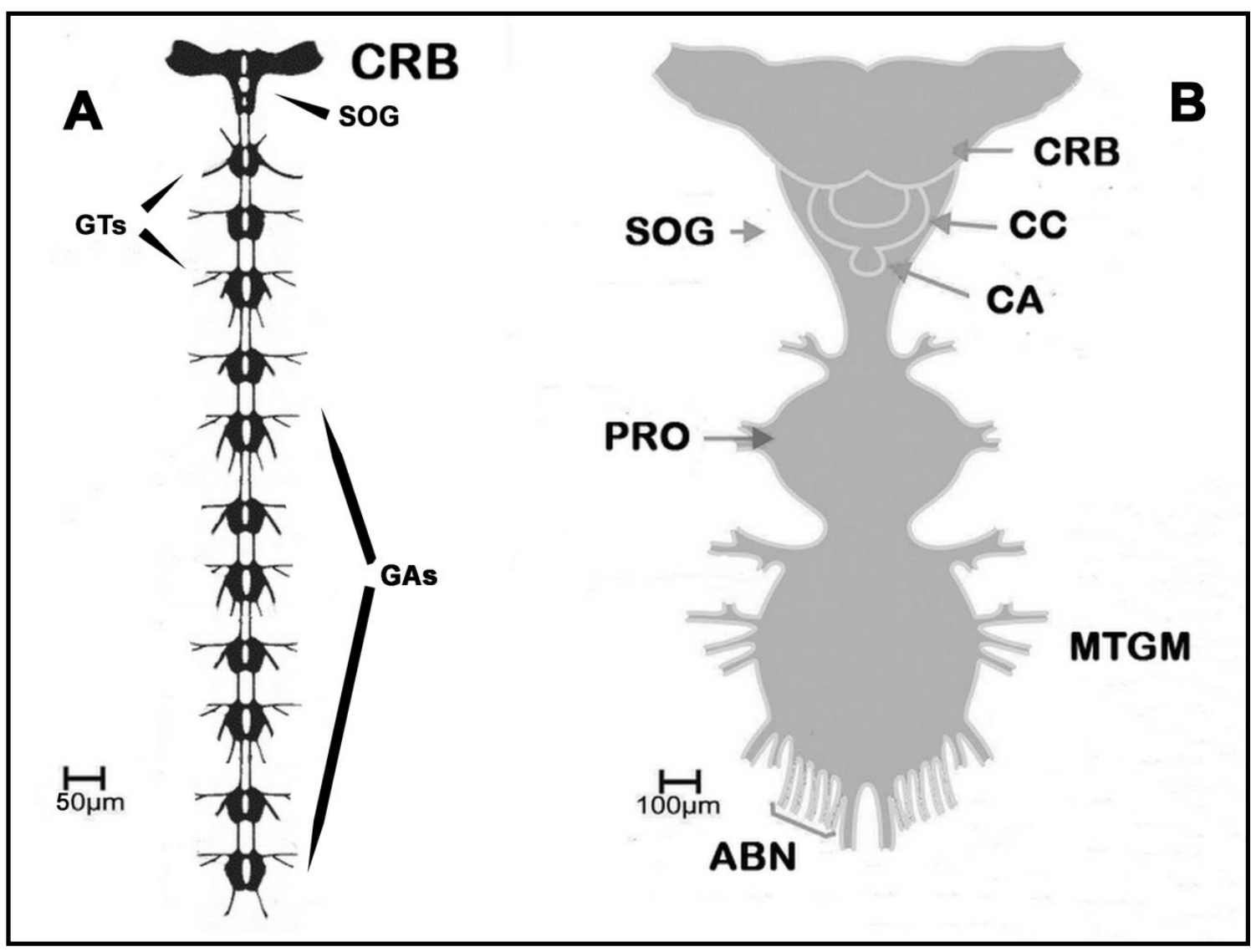

Figura 1.1: (A) Esquema del sistema nervioso central de un dipluro, disposición típica del SNC de los primeros insectos. CRB: cerebro; SOG: ganglio subesofágico; GTs: ganglios torácicos; GAs: ganglios abdominales. (B) Esquema del sistema nervioso de los triatominos (hemípteros), nótese la fusión los ganglios en dos grandes ganglios torácicos. CRB: cerebro; CA: corpora allata; CC: corpora cardiaca; SOG: ganglio subesofágico; PRO: ganglio protoráxico; MTGM: ganglio mesometatoráxico (se agradece a Natalia Esponda por realizar gentilmente la ilustración B).

En los triatominos, al igual que en los demás insectos, el SOG genera proyecciones nerviosas que inervan la CC y las glándulas salivales (Fig. 1.2 B). Este ganglio es también responsable del movimiento de las piezas del estomodeo. Con respecto al PTG, su rol principal es el control y movimiento de los apéndices locomotores, y además posee una función neuroendocrina. Por último, a partir del MTGM se generan cinco pares de nervios que inervan los distintos segmentos del abdomen, denominados nervios abdominales (ABN; del inglés abdominal nervs). El par central es el más largo e inerva la genitalia $(\mathrm{ABN} V)$. Los demás $\mathrm{ABNs}$ inervan todos los órganos y tejidos abdominales del insecto: sistema digestivo, respiratorio, cuerpo graso, membranas inter-segméntales de la cutícula y receptores físicos y químicos cuticulares (Griss 1990; Insausti 1994). 
Con respecto a la función neuroendocrina, el protocebro en conjunto con el complejo CC - Corpora Allata (CA) son importantes centros de almacenamiento y liberación de neuropéptidos. Del mismo modo, los ganglios y nervios que integran el PTG, el MTGM y los ABNs son órganos neuroendocrinos relevantes.

Con respecto al protocerebro, las neuronas productoras de hormonas se localizan principalmente en las región denominada Pars Intercerebralis (PI) y Pars Lateralis (PL) (Pipa 1978). En la región PI, se destacan la células neurosecretoras mediales (MNS) (Fig. 1.2 B). En este área se expresan hormonas como las diuréticas (DH31 y DH44; del inglés diuretic hormone), péptidos símil-insulina (ILP; del inglés insuline like peptide), FMRFamida, la hormona dispersora de pigmentos (PDF; del inglés pigment dispersing factor), corazonina (CZ; del inglés corazonin), SIFamida, proctolina (PRT; del inglés proctolin) y allatostatina A (Ast-A; del inglés allatostatin) (Davey 1961; Kriger and Davey 1982; Te Brugge, Nassel et al. 2001; Nassel 2002; Orchard and Brugge 2002; Te Brugge and Orchard 2002; Siga 2003; Orchard, Lee et al. 2011; Hamoudi, Lange et al. 2016). Por otro lado, en la región PL, donde se destaca la presencia de las células neurosecretoras laterales anteriores (LANS; del inglés lateral anterior neurosecretory cells) (Fig. 3 B), se observa la expresión de los péptidos como FMRFamida, PDF, CZ y Ast-A. En algunos insectos PL además, es responsable de la regulación de la producción de la hormona juvenil ( $\mathrm{JH}$; del inglés juvenile hormone) vía la CA (Stay, Fairbairn et al. 1996; Stay 2000).

También se han descripto neuronas con actividad secretora en el tritocerebro, donde se destacan las células neurosecretoras dorsales (DNS; del inglés dorsal neurosecretory cells) (Fig. 1.2 B), cuya función se asocia con la regulación de los ritmos circadianos (Nassel 2002; Steel and Vafopoulou 2006).

En el MTGM también se detectan células neurosecretoras. Podemos destacar las células neurosecretoras laterales posteriores (PL; del inglés posterior lateral neurosecretory cells) y las neuronas dorsales no pareadas mediales (DUM; del inglés dorsal umparied medial neurons) (Fig. 1.2 C). En $R$. prolixus estas células secretan péptidos diuréticos como el factor liberador de corticotropina (CRF; del inglés corticotropin releasing factor símil DH) en el caso de las PLs, y la hormona calcitonina diurética (CT; del inglés calcitonine símil DH) en el caso de las DUMs (Fig. 1.2 C) (Te Brugge, Lombardi et al. 2005; Te Brugge and Orchard 2008). El MTGM posee también 
un grupo de células neurosecretoras ventro-mediales (VM; del inglés ventro medial neurosecretory cells) que producen factores antidiuréticos como el péptido cardioacelerador (CAPA; del inglés cardio acceleratory peptide) (Fig. 1.2 C) (Paluzzi and Orchard 2006).

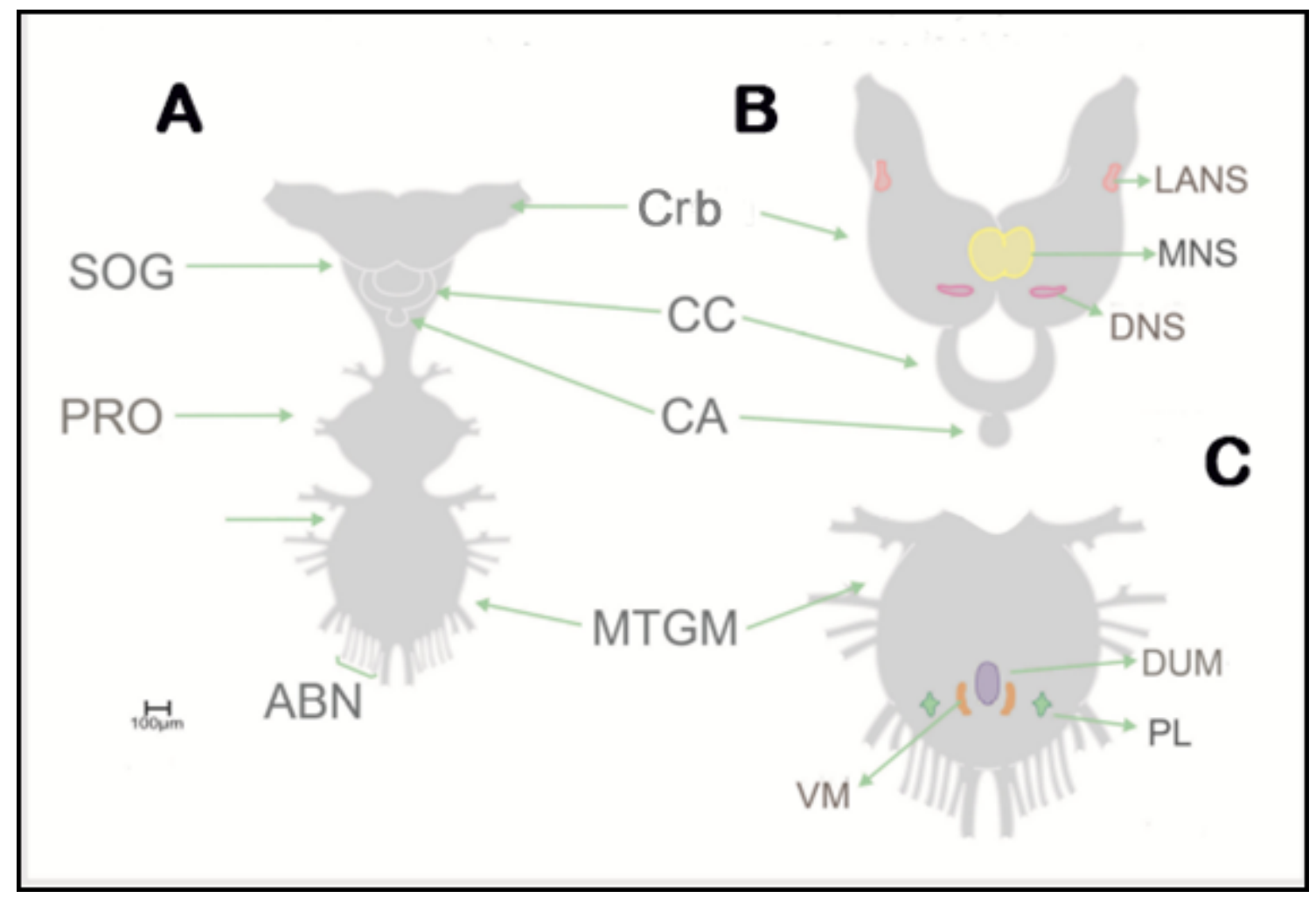

Figura 1.2: (A) Esquema del sistema nervioso central de un triatomino. Crb: cerebro; ABN: nervios abdominales; CA: corpora allata; CC: corpora cardiaca; PRO: ganglio protoráxico; SOG: ganglio subesofágico. (B) Detalle de las células neurosecretoras del cerebro. LANs: neuronas antero-laterales; MNS: células neurosecretoras mediales; DNS: células neurosecretoras dorsales. (C) Detalle de las células neurosecretoras del MMTG. DUM: neuronas dorso-mediales no pareadas; PL: células neurosecretoras postero-laterales; VM: células neurosecretoras ventro-mediales (se agradece a Natalia Esponda por realizar gentilmente la ilustración).

\subsubsection{La orcokinina en insectos}

Muchos de los neuropéptidos de artrópodos han sido identificados inicialmente mediante el uso de ensayos de contracción de tejidos tales como aorta, intestino medio anterior y posterior (Stangier, Hilbich et al. 1987; Veenstra 1989; Schoofs, Holman et al. 1991; Orchard, Lee et al. 2011). Estos métodos posibilitaban una rápida y eficiente caracterización funcional, proceso por el cual se estudiaron inicialmente muchas moléculas hasta ese momento desconocidas. Por el modo de identificación, en un comienzo se las denominó de acuerdo al bioensayo para el cual resultaban positivas, por 
ejemplo: corazonina, miosupresina, péptidos mioinhibitorios (Ast-B), péptido cardioacelerador de los crustáceos, etc.

El conocimiento sobre los neuropéptidos en insectos se ha expandido notablemente en las últimas dos décadas (Altstein and Nassel 2010), y de igual forma se han complejizado y desarrollado las técnicas para su estudio y caracterización funcional (Fig. 1.3) (Verleyen, Huybrechts et al. 2009; Sterkel, Urlaub et al. 2011; Romanova and Sweedler 2015).

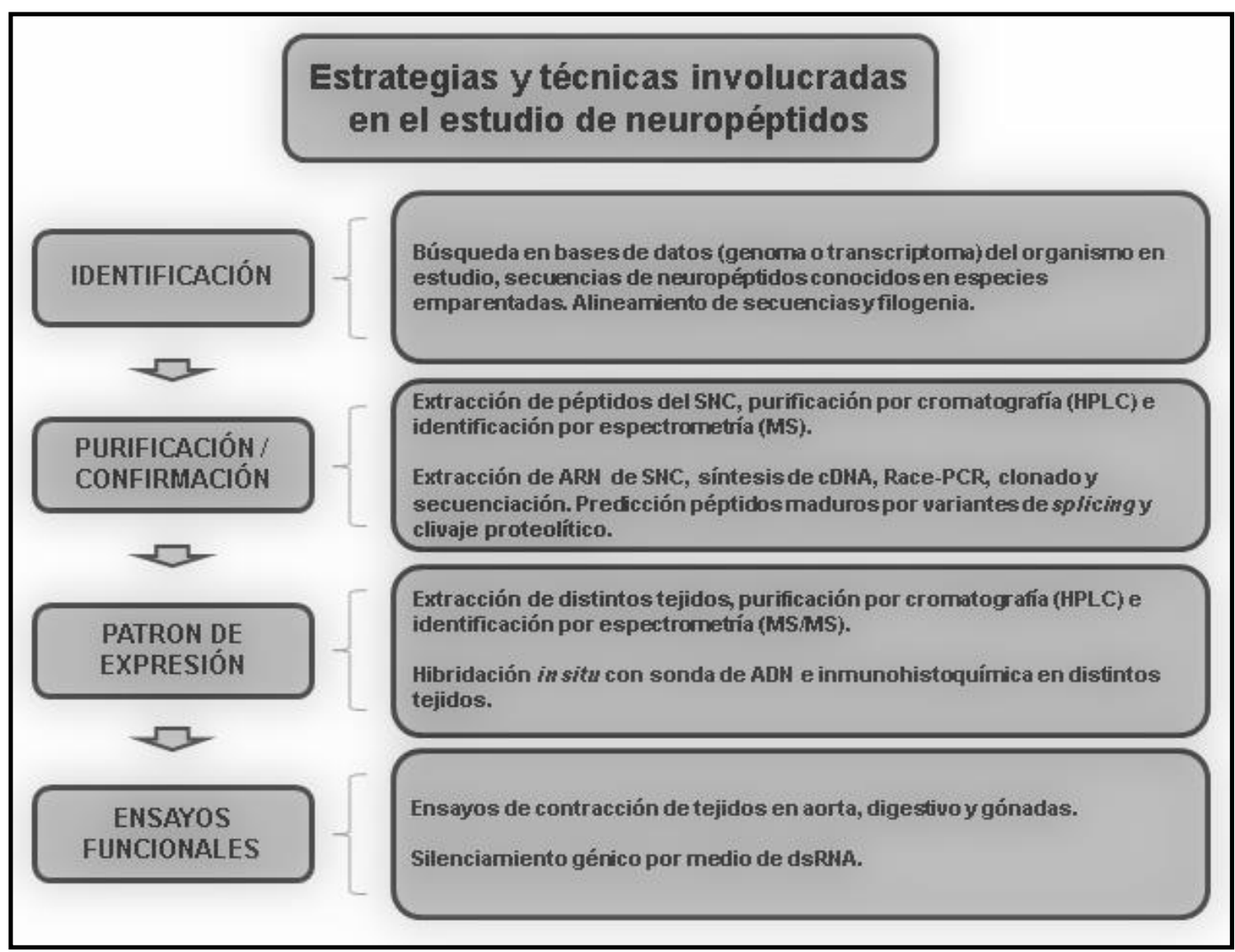

Figura 1.3: Esquema del flujo de trabajo usual en el estudio de neuropéptidos. SNC: sistema nervioso central; HPLC: cromatografía liquida de alta performance; MS: espectrometría de masas; MS/MS: espectrometría de masas en tándem.

Las caracterizaciones funcionales desde un enfoque más completo demostraron que en la mayoría de los casos, los neuropéptidos poseen un papel fisiológico de carácter pleiotrópico, y no sólo relacionado con actividad por la cual inicialmente fueron identificados (Wang, Orchard et al. 1995; Gade 1997; Gade, Hoffmann et al. 1997; Ma, Kutz-Naber et al. 2007; Mykles, Adams et al. 2010). Incluso en ciertos casos, se observó actividad miotrópica para péptidos identificados inicialmente por medios 
informáticos (Orchard, Lee et al. 2011). Gracias a los métodos modernos de alto rendimiento, como la genómica, transcriptómica y proteómica, actualmente se han identificado muchos neuropéptidos en bases de datos de insectos, para los cuales no se han reportado ensayos funcionales con resultados definitivos a la fecha. Entre ellos, podemos nombrar a los péptidos: neuropéptido símil precursor 1 (NPLP1; del inglés neuropéptide like precursor 1), péptido ITG (ITG), péptido NVP (NVP), péptido CNM amidado (CNM-amida), ryamida (RY-amida) y elevenin 1 y 2 (Elevin-1 y Elevin-2), para los cuales no se ha reportado su rol funcional actualmente en ninguna especie (Ons, Richter et al. 2009; Hauser, Neupert et al. 2010; Ons, Sterkel et al. 2011; Jung, Manoharan et al. 2014; Tanaka, Suetsugu et al. 2014; Ons, Lavore et al. 2016).

Las orcokininas (OKs) por su parte, son neuropéptidos de artrópodos identificados y caracterizados inicialmente en el crustáceo Orconectes limosus al cual deben su nombre (Stangier, Hilbich et al. 1992). Ensayos realizados con uno de los péptidos maduros generados por el precursor OrcliOK (NFDEIDRSGFGFN) revelaron actividad miotrópica en intestino posterior de este organismo (Stangier, Hilbich et al. 1992). Los primeros estudios funcionales sobre OKs se centraron en crustáceos, testeando el potencial miotrópico de las orcokininas en distintas especies de esta clase de artrópodos (Bungart, Dircksen et al. 1994; Bungart, Kegel et al. 1995; Dircksen, Burdzik et al. 2000; Ma, Kutz-Naber et al. 2007).

En los insectos, las OKs fueron identificadas por primera vez en la cucaracha Blattella germanica (Pascual, Castresana et al. 2004). Desde entonces hasta el año 2011 únicamente la isoforma OKA había sido descripta. En ese año, nuestro grupo de investigación consiguió demostrar la existencia de OKB (Sterkel, Oliveira et al. 2012), que se origina como variante de splicing del gen $\mathrm{OK}$. La presencia de ambas isoformas fue confirmada en todos los genomas de insectos disponibles hasta la fecha, con un alto grado de conservación a nivel de secuencia (Figs. 1.5 y 1.7).

En todas las especies, con excepción de T. castaneum (Jiang, Kim et al. 2015), OKA y OKB dan origen a familias de neuropéptidos maduros completamente distintas a nivel de secuencia (Fig. 1.6). El patrón de expresión de ambas isoformas también parece ser muy diferente: OKA se expresa principalmente en sistema nervioso, mientras que OKB está presente en sistema nervioso e intestino (Hofer, Dircksen et al. 2005; Ons, Sterkel et al. 2011; Yamanaka, Roller et al. 2011; Sterkel, Oliveira et al. 2012; Veenstra 
and Ida 2014; Chen, Choi et al. 2015; Jiang, Kim et al. 2015; Ons, Belles et al. 2015). Durante el desarrollo del presente trabajo hemos detectado además que ambos precursores son expresados en gónadas en R. prolixus (ver Resultados).

Junto con su identificación, el primer estudio funcional en insectos fue el análisis de actividad miotrópica de OKA en intestino medio anterior y posterior de la cucaracha B. germanica con resultados negativos (Pascual, Castresana et al. 2004). Sin embargo, ensayos recientes de nuestro grupo de trabajo en $R$. prolixus señalan actividad en la estimulación de la contracción aórtica para ambas isoformas (OKA y OKB), y de las contracciones peristálticas del intestino sólo para OKB (Wulff, Capriotti et al. 2018, manuscrito en revisión) (ver resultados Cap. 1).

El patrón de expresión de OKA en SNC de R. prolixus fue estudiado en nuestro laboratorio (Sterkel 2011; Sterkel, Urlaub et al. 2011; Wulff, Sierra et al. 2017). Los ensayos evidenciaron inmunoreactividad positiva para OKA (OALI) en neuronas del cerebro, particularmente en los lóbulos ópticos y antenales (Fig. 1.4 A).

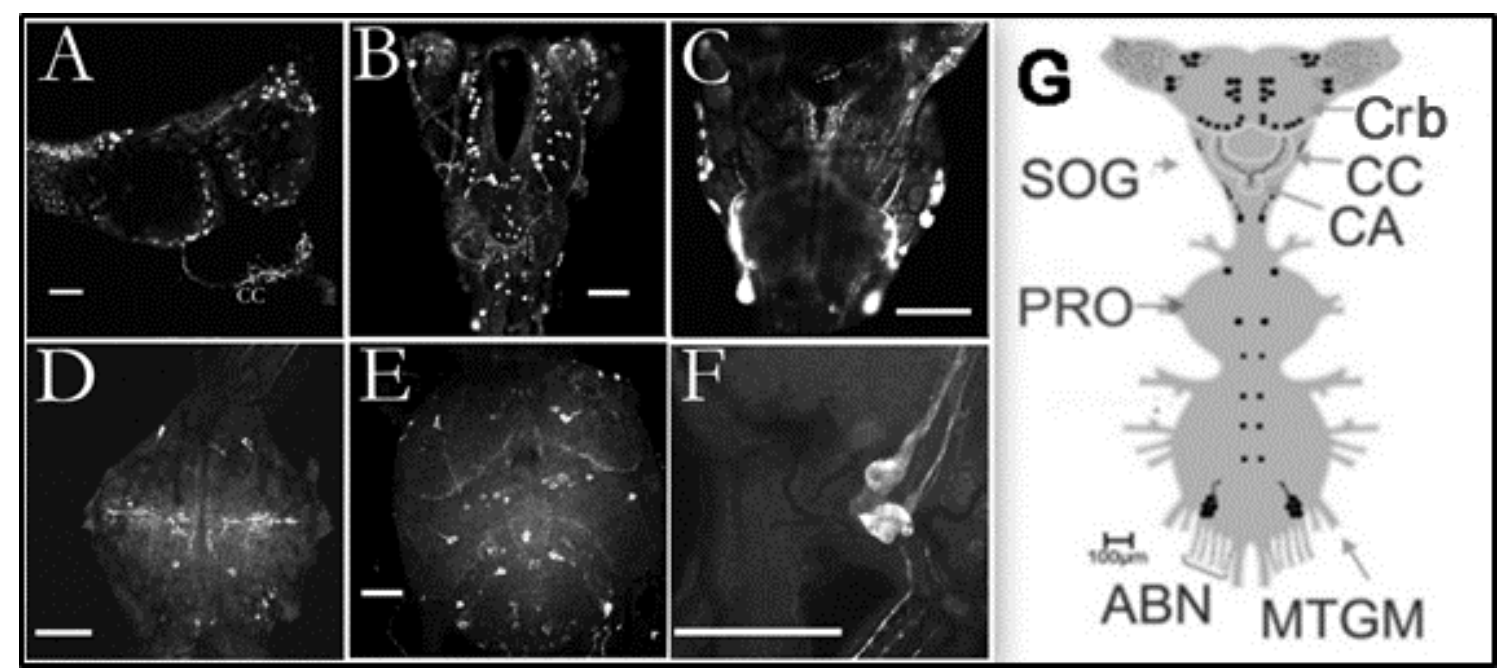

Figura 1.4: Inmunoreactividad positiva para OKA en tejidos periféricos de $R$. prolixus. (A) Vista dorsal del Cerebro. Se observa OALI en CC, en las células laterales circadianas o de reloj (B) Vista ventral de Cerebro y SOG. (C) Vista dorsal del SOG. (D) PTG. (E) MTGM. (F) Detalle de NSCs laterales posteriores del MTGM y ABNs (G) Esquema representando las NSCs y sus procesos asociados, más intensamente teñidos en: Cerebro, SOG, PTG, MTGM, CC y CA. Barra blanca: 100 $\mu$ mts (Sterkel 2011; Sterkel, Urlaub et al. 2011; Wulff, Sierra et al. 2017). Se agradece a Natalia Esponda por realizar gentilmente la ilustración $\mathrm{G}$.

En otras especies de insectos, se observó marcación positiva en áreas del protocerebro como médula anterior, médula accesoria y cuerpos fungiformes en insectos hemimetábolos de las especies Locusta migratoria, Schistocerca gregaria y 
Leucophaea maderae (Hofer, Dircksen et al. 2005). Posteriormente se confirmó la presencia de OKA en SNC, y $\mathrm{OKB}$ en intestino de insectos holometábolos de las especies T. castaneum, Bombyx mori y D. melanogaster (Yamanaka, Roller et al. 2011; Veenstra and Ida 2014; Chen, Choi et al. 2015; Jiang, Kim et al. 2015).

Los resultados respecto de marcación positiva a nivel de cerebro inicialmente descubiertos en L. maderae (Hofer, Dircksen et al. 2005) fueron posteriormente confirmados en B. mori (Yamanaka, Roller et al. 2011), y por nuestro grupo de investigación en el triatomino R. prolixus (Sterkel 2011; Sterkel, Urlaub et al. 2011; Wulff, Sierra et al. 2017). Además, grupos de células neurosecretoras (NSCs) localizadas en diferentes áreas del cerebro evidenciaron también intensa OALI en ambas especies: neuronas del límite ubicado entre el protocerebro y los lóbulos ópticos; NSCs de la región posterior y lateral del cerebro; grupo de NSCs en forma medial respecto de cada lóbulo del cerebro; neuronas de la región posterior dorsal; células ubicadas en el margen posterior de los lóbulos protocerebrales; y finalmente la Corpora Cardiaca, el cual constituye un órgano neurohemal central también mostró intensa OALI (Fig. 1.4 A) (Hofer, Dircksen et al. 2005; Sterkel 2011; Sterkel, Urlaub et al. 2011; Yamanaka, Roller et al. 2011; Wulff, Sierra et al. 2017).

Dentro del SNC se detectó OALI en los ganglios SOG, MTGM y PTG (Sterkel 2011; Sterkel, Urlaub et al. 2011; Yamanaka, Roller et al. 2011; Wulff, Sierra et al. 2017). En $R$. prolixus se identificaron dos pares de proyecciones axonales con OALI, extendidos desde el SOG hasta el ganglio MTGM atravesando transversalmente el PTG. Células bilaterales fuertemente teñidas se detectaron en los márgenes anteriores y posteriores del PTG. Un grupo de células del margen anterior del PTG evidenció marcación, con proyecciones posteriores a partir de estas células, también teñidas. Intensa marcación de neurópilos y cuerpos neuronales se pudo detectar en toda la estructura del PTG tanto en la cara dorsal como ventral. Por otra parte, el MTGM evidenció aproximadamente 80 células con OALI (Fig. 1.4 C, D y E). A lo largo de toda la estructura del ganglio se detectó intensa marcación de neurópilos. Las proyecciones axonales a lo largo de toda la línea media del MTGM, desde la conexión con el PTG hasta el final del MTGM también presentó reactividad (Fig. 1.4 G). Además, grupos de 5 NSCs bilaterales pareadas mostraron fuerte OALI, con proyecciones anteriores hacia un grupo no pareado de neuronas moderadamente reactivas, y proyecciones posteriores hacia los nervios abdominales (Sterkel 2011; Wulff, Sierra et al. 2017). 
En el caso de B. mori, se observó OALI en neuronas mediales y laterales del ganglio SOG. También se detectaron dos grupos de neuronas ventro-mediales con intensa marcación en el ganglio mesotoráxico. Finalmente en los ganglios abdominales se observaron neuronas que evidenciaron OALI, destacándose el ganglio abdominal terminal donde se identificaron dos pares de neuronas postero-mediales (Yamanaka, Roller et al. 2011).

Con respecto al patrón de expresión de $\mathrm{OKB}$, los antecedentes previos a este trabajo muestran inmuno reactividad positiva (OBLI) en SNC e intestino medio de los insectos holometábolos T. castaneum y D. melanogaster (Veenstra and Ida 2014; Chen, Choi et al. 2015; Jiang, Kim et al. 2015). Además, por RT-PCR se identificó el precursor del gen $\mathrm{OKB}$ en SNC e intestino medio de B. germanica (Ons, Belles et al. 2015). Con respecto a T. castaneum, el patrón de expresión de OKB es de gran similitud al patrón de expresión de OKA. Ambos transcriptos son expresados tanto en cerebro como en intestino medio (Jiang, Kim et al. 2015). Cabe destacar, que en este insecto ambas isoformas poseen una elevada similitud de secuencia (símil OKA). Respecto a $D$. melanogaster, los péptidos maduros generados por el gen $\mathrm{OKB}$ se expresan fundamentalmente en intestino medio, encontrándose representados en SNC sólo por una gran neurona no pareada presente en la región postero medial del ganglio abdominal (Chen, Choi et al. 2015).

A pesar de ser un sistema peptídico altamente conservado en insectos, la función fisiológica de OKs prácticamente no había sido estudiada hasta la fecha de inicio de la presente Tesis Doctoral. Un trabajo inicial en este sentido (Hofer and Homberg 2006), indicó un posible rol de OKA en la regulación de ritmos circadianos. Se observó en la cucaracha L. maderae OALI en células denominadas de reloj ubicadas en la Médula Accesoria (MeA), asociadas con la regulación de la actividad locomotora circadiana (Hofer and Homberg 2006). En este trabajo se inyectó localmente en MeA el péptido de secuencia NFDEIDRSGF (OKA), codificado en el precursor de OKs de O. limosus. El experimento reveló una desregulación del ritmo circadiano asociado a actividad locomotora (Hofer and Homberg 2006).

El silenciamiento transcripcional tanto de OKA, como de OKB en T. castaneum, por otra parte, provocó alteraciones en el comportamiento innato de muerte fingida, que realizan algunos coleópteros cuando se ven amenazados (Jiang, Kim et al. 2015). 
En el lepidóptero B. mori (gusano de seda), estudios in vitro utilizando OKA sintético mostraron un aumento en la síntesis y/o liberación de ecdisteroides (Yamanaka, Roller et al. 2011). El ensayo fue realizado con dos péptidos maduros generados por BommoOKA: Bommo Orc I: NFDEIDRSSLNTFV y Bommo Orc II: NFDEIDRSSMPFPYAI. A una concentración de trabajo de $10^{-5} \mathrm{M}$, se observó un aumento significativo $(\mathrm{p}<0,01 ; \mathrm{n}=4)$ en la concentración de ecdisteroides respecto de los controles, medido por radioinmunoensayo (Yamanaka, Roller et al. 2011). Estudios realizados en la cucaracha $B$. germánica señalaron además, un papel de OKA y OKB en la ovogénesis (Ons, Belles et al. 2015). Se silenciaron ambas isoformas en forma conjunta y por separado. Únicamente el silenciamiento conjunto de ambas isoformas del gen tuvo como efecto una disminución en la vitelogénesis y como consecuencia en la maduración de los ovocitos (Ons, Belles et al. 2015).

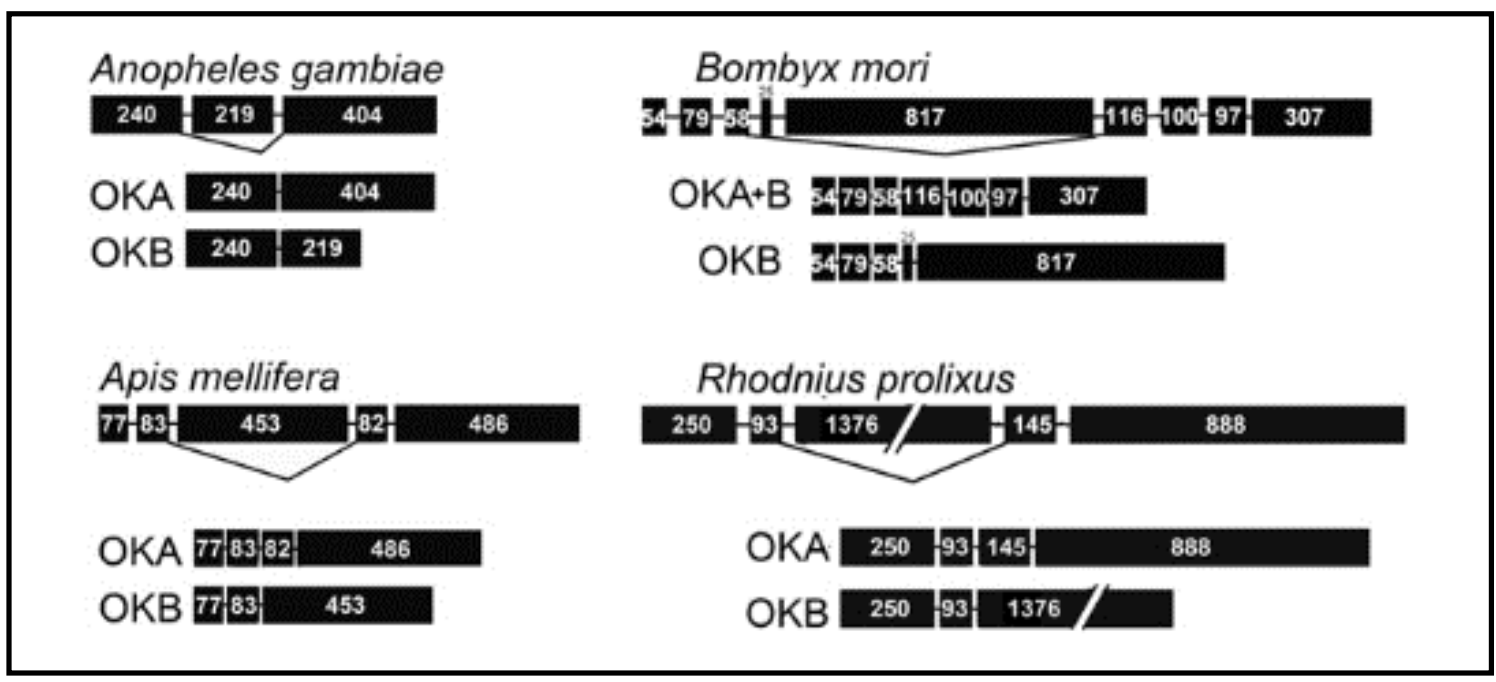

Figura 1.5. Estructura del precursor de orcokinina en diferentes especies de insectos. El número dentro de cada exón (caja negra) indica la longitud en cantidad de bases, y las líneas que los conectan representan los intrones. Además se detalla la construcción de OKA y OKB (u OKA+B en B. mori) por splicing alternativo del gen OK (Sterkel, Oliveira et al. 2012).

- OKA

NFDEIDRSGF (secuencia mas habitual en insectos)

Péptidos maduros con la secuencia: $\mathrm{X}_{1}$ LDXXXGXG $\left(\mathrm{X}_{1}\right.$ : $\mathrm{N}$ o $\left.\mathrm{S}\right)$

$=\mathbf{O K B}$

$>\mathrm{X}_{1} \mathrm{LDXXXGGGX}_{2} \mathrm{LX}_{3}$ (secuencia mas habitual en insectos) $\left(\mathrm{X}_{1}: \mathrm{N}\right.$ o $\mathrm{S} ; \mathrm{X}_{2}: \mathrm{N}, \mathrm{S}$ o H; $\mathrm{X}_{3}: \mathrm{I}, \mathrm{L}$ o V)

Figura 1.6: Secuencia mayormente conservada entre distintas especies de insectos para los péptidos maduros OKA u OKB. 


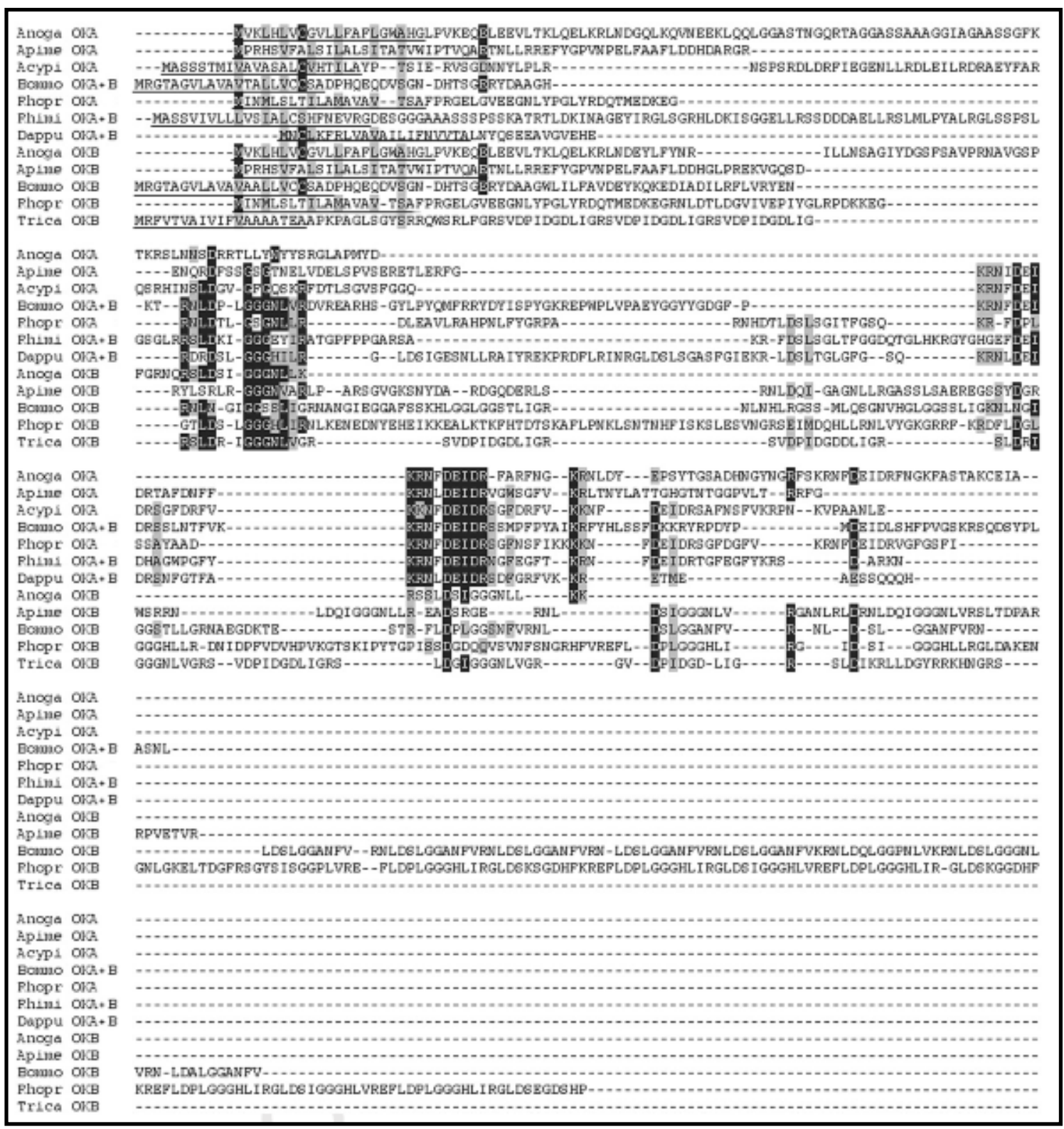

Figura 1.7: Alineamiento de OKA, OKB y OKA+B en diferentes artrópodos. Anoa: Anopheles gambiae; Apime: Apis mellifera; Bommo: Bombyx mori; Pedu: Pediculus humanus; Rhopr: Rhodnius prolixus; Acypi: Acyrthosiphon pisum; Rhimi: Rhipicephalus microplus; Dappu: Daphnia pulex; Trica: Tribolium castaneum. Se detallan además los aminoácidos idénticos (negros) o similares (gris) entre secuencias de distintas especies, y el péptido señal se encuentra subrayado en cada caso (Sterkel, Oliveira et al. 2012). 


\subsubsection{Hipótesis}

Existen otra/s isoforma/s del gen RhoprOKs, además de RhoprOKA y RhoprOKB anteriormente descriptas.

El patrón de expresión de la orcokinina en $R$. prolixus es diferencial por isoformas, y se relaciona con la función fisiológica en cada caso.

\subsubsection{Objetivos específicos}

$>$ Caracterizar estructuralmente el gen de orcokinina en $R$. prolixus, con sus variantes de splicing e isoformas resultantes.

- Estudiar el patrón de expresión en $\mathrm{SNC}$ y tejidos periféricos de RhoprOKB, y en tejidos periféricos para RhoprOKA, como primera aproximación para el estudio de su papel fisiológico. 


\subsection{MATERIALES y MÉTODOS}

\subsubsection{Insectos}

Los insectos de la especie $R$. prolixus fueron obtenidos de una colonia establecida en el Centro Regional de Estudios Genómicos (CREG - Fac. Cs. Exactas UNLP), mantenida a una temperatura de $28 \pm 2^{\circ} \mathrm{C}$ y $60 \%$ de humedad relativa, con un ciclo de 12:12 horas de luz / oscuridad. Los insectos son alimentados ad libitum, una vez por cada estadio del ciclo vital sobre gallinas mantenidas en acuerdo con las pautas establecidas por el Protocolo Nacional de Referencia Ética para estudios Biomédicos en Laboratorio, A campo, o animales colectados en la Naturaleza. Este protocolo está en acuerdo con los estándares establecidos por la Oficina para el correcto uso de animales de Laboratorio, Departamento de Salud y Servicios Humanos, NIH y recomendaciones estipuladas por la Directiva del Parlamento Europeo 2010/63/EU, relativa a la protección de animales usados con fines científicos. Todos los ensayos se iniciaron aproximadamente una semana post ecdisis, en insectos ayunados desde el estadio anterior. Los ensayos de inmunohistoquímica (IHQ) se desarrollaron utilizando ninfas de $5^{\text {to }}$ estadio e insectos adultos. La caracterización molecular de la isoforma RhoprOKC se realizó sobre insectos adultos.

\subsubsection{Caracterización de RhoprOKC}

\subsubsection{Identificación y análisis bioinformático}

Para realizar la búsqueda por homología de secuencia se utilizó una base de datos de ESTs de $R$. prolixus (http://rhodnius.iq.ufrj.br/index.php?option=comcontent

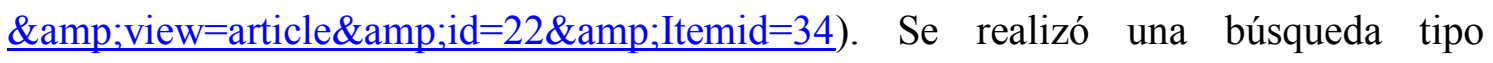
TBLASTN, mediante el uso de la matriz BLOSUM62 y la secuencia de RhoprOKB (número de acceso Genbank ${ }^{T M}: \mathrm{JF761320)}$ como guía de referencia (E value: $\mathrm{E}^{-22}$ ). La secuencias positivas fueron comparadas con el genoma de $R$. prolixus (http://rprolixus.vectorbase.org/) y curadas manualmente. 
La presencia de péptido señal fue determinada mediante el programa SignalP ((Petersen, Brunak et al. 2011); http://www.cbs.dtu.dk/services/SignalP/). Para predecir los posibles sitios de clivaje proteolítico del precursor y posibles PTMs (del inglés post traductional modifications) de los péptidos maduros, se utilizó un algoritmo estadístico (http://www.neuroproteomics.scs.uiuc.edu/neuropred. html) y se siguieron las reglas descriptas previamente a tal fin (Veenstra, Martinovic et al. 2000). Los alineamientos de secuencias se realizaron con el programa Clustal $\Omega$ (http://www.ebi.ac.uk/Tools/msa (clustalo/).

\subsubsection{Disección de tejidos}

Los tejidos fueron micro-disecados con pinzas quirúrgicas de titanio y hojas de afeitar. La disección se realizó bajo lupa binocular (Zeiss 4750 57) bajo solución salina modificada para $R$. prolixus (ver anexo). Los tejidos se colocaron en tubos tipo eppendorf de 1,5mL que contenían 500 $\mu$ ls de reactivo Trizol (Invitrogen, Carlsbad, CA, USA), y posteriormente conservados a $-80^{\circ} \mathrm{C}$ hasta el momento de la extracción de ARN.

\subsubsection{Extracción de ARN total}

Se procedió a la extracción del ARN total de los tejidos de acuerdo al protocolo descripto previamente (Chomczynski and Sacchi 1987). Se tomaron en cuenta además, las instrucciones descriptas por el fabricante en el protocolo del reactivo Trizol (https://tools.thermofisher.com/content/sfs/manuals/trizol_reagent.pdf), sobre el cual se hicieron modificaciones (ver anexo, extracción de ARN). Los ensayos se realizaron manteniendo las muestras en un bloque frío (aproximadamente $0-4^{\circ} \mathrm{C}$ ), bajo campana de extracción con solventes orgánicos. Las muestras se homogeneizaron manualmente utilizando pistilos de plástico desechables. Una vez completo el protocolo de extracción las muestras de ARN, una alícuota de cada muestra se sometió a electroforesis en gel de agarosa $1 \%$ para confirmar su integridad y estimar su cantidad (ver anexo, cuantificación en gel de agarosa). El ARN fue conservado a $-80^{\circ} \mathrm{C}$ hasta el momento de la síntesis del ADNc. 


\subsubsection{Síntesis de ADNc}

El ADNc se sintetizo utilizando el protocolo de la enzima transcriptasa reversa M-MLV (Promega ${ }^{\circledR}$ ). Se procedió a la síntesis de la simple hebra de ADNc a partir de $1 \mu \mathrm{g}$ de ARN. El protocolo se detalla en el anexo: "síntesis de ADNc". Posteriormente se utilizó 1 ul de cada muestra para realizar una RT-PCR control (ver anexo, protocolo PCR), a fin de chequear el estado correcto del ADNc. Se desarrolló una PCR de 35 ciclos de duración y se utilizaron primers para amplificar una secuencia de 300pb dentro del gen RhoprACTIN (ver anexo, primers). Diez $\mu$ ls del producto de PCR fueron sometidos a electroforesis en gel de agarosa, observado en el software de imágenes ImageJ2x (ver anexo, electroforesis en gel de agarosa).

\subsubsection{Race-PCR}

Para obtener la secuencia completa del transcrito RhoprOKC se utilizó la técnica denominada Race-PCR (del inglés, Rapid extension of cDNA ends), a fin de lograr la elongación del extremo 3', que está ausente de la bases de datos genómica. Se realizó una RT-PCR (ver anexo, protocolo PCR), utilizando los primers OKA/B Fwd y GeneRacer 3 ' primer $^{\circledR}$ (ver anexo, primers). El extremo 5' se completó por búsqueda en base de datos (http://rprolixus.vectorbase.org/) y mediante predicción bioinformática.

Los primers "genracer" fueron obtenidos del kit GENERACER KIT (Invitrogen, Argentina) (ver anexo primers).

\subsubsection{Secuenciación}

A fin de obtener el producto final de RhoprOKC se realizó una PCR (ver anexo, protocolo PCR) de 35 ciclos utilizando como molde ADNc extraído de cuerpo total de ninfa de $5^{\circ}$ estadio, con los primers OKC Fwd y GeneRacer 3' nested primer ${ }^{\circledR}$ (ver anexo, primers). El producto de PCR se sometió a electroforesis en gel de agarosa 1\% (ver anexo, electroforesis en gel de agarosa), y se visualizó y fotografió con un sistema integrado por una cámara $\mathrm{CANON}^{\mathrm{TM}}$ Eos Rebel, y el software de procesamiento de 
imágenes canon eos utility. La banda de tamaño de interés fue eluída del gel con un kit comercial QUIAGEN ${ }^{\mathrm{TM}}$ (USA), de acuerdo a las especificaciones del fabricante con modificaciones (ver anexo, elusión de $\mathrm{ADN}$ en gel de agarosa). Posteriormente $1 \mu 1$ del producto obtenido fue re amplificado en una segunda PCR bajo las mismas condiciones que la primera. El producto de amplificación fue precipitado con etanol a fin de aumentar su concentración (ver anexo, precipitación etanólica). Finalmente, $1 \mu \mathrm{g}$ del amplicon purificado fue enviado a Macrogen ${ }^{\circledR}$ (Seúl, Corea del Sur) para su pirosecuenciación, utilizando los primers OKC Fwd y 3' GeneRacer nested primer (ver anexo, primers).

\subsubsection{Patrón de expresión mediante RT-PCR}

Para determinar el patrón de expresión de RhoprOKC vía RT-PCR se disecaron bajo lupa binocular separadamente SNC, ovarios, testículos, intestino medio anterior, intestino medio posterior y recto, de insectos adultos dos semanas post-ecdisis, bajo ayuno. Se analizó la expresión del transcripto mediante RT-PCR (ver anexo, protocolo PCR), utilizando los primers PCR_OKC Fwd Y PCR_OKC Rev. Se utilizó como molde $1 \mu 1$ de ADNc obtenido y sintetizado siguiendo los protocolos de extracción de ARN y síntesis de ADNc detallados en anexo, mencionado en los apartados anteriores. La reacción tuvo una duración de 35 ciclos.

\subsubsection{Inmunohistoquímica}

Se removió la cutícula dorsal de ninfas de $5^{\text {to }}$ estadio (ver anexo, protocolo inmunohistoquímica) de $R$. prolixus de dos semanas post-ecdisis, bajo ayuno.

El anticuerpo primario anti-OKA ( $\alpha \mathrm{Asn}^{13}$-orcokinin) fue provisto gentilmente por el Dr. H. Dircksen (Department of Zoology, Stockholm University). El anticuerpo fue generado contra un péptido de secuencia NFDEIDRSGFGFN. El anticuerpo primario anti-OKB/C fue producido por la empresa Genscript ${ }^{\circledR}$ (Piscataway, NJ, USA). Este anticuerpo fue generado en conejos, los cuales fueron inyectados y sensibilizados para el péptido cuya secuencia es: EFLDPLGGGHLIC (secuencia más abundante en el pre-propéptido RhoprOKB/C). Se utilizó además, T-Max (Genscript ${ }^{\circledR}$, Piscataway, NJ, 
USA) como adyuvante. Una vez extraído del suero de conejo se caracterizó la afinidad máxima del anticuerpo por la técnica de ELISA. La empresa reportó una titulación de 1:512000 (ver anexo, protocolo Inmunohistoquímica). Las muestras se registraron en un Microscopio Confocal LSM510-Zeiss con el software de imagen para dicho dispositivo (LSM510-Zeiss, Germany). Para el control de especificidad de ambos anticuerpos (anti-OKA y anti-OKN); se incubaron los tejidos sin la presencia de anticuerpo primario, o en presencia de anticuerpo primario previamente pre-adsorvido durante toda la noche a temperatura ambiente con una solución $1 \mathrm{mM}$ de péptido sintético específico para cada caso (Genscript, Piscataway, NJ, USA). 


\subsection{RESULTADOS y DISCUSIÓN}

\subsubsection{Identificación y caracterización de RhoprOKC}

La búsqueda tipo TBLASTN en una base de datos de ESTs de cuerpo entero de $R$. prolixus sugirió la presencia de una nueva isoforma del gen RhoprOK desconocida hasta ese momento. La misma resultó compuesta por los dos exones del gen previamente descripto, más un exón que se encuentra ausente en las isoformas RhoprOKA y RhoprOKB, previamente descriptas.

Se realizó una Race-PCR a fin de conocer la secuencia completa del transcripto (Fig. 1.8). Mediante esta estrategia se logró secuenciar completamente la nueva isoforma, la cual se denominó RhoprOKC, de acuerdo con las reglas de la nomenclatura (Coast and Schooley 2011). La secuencia RhoprOKC fue registrada en Genbank ${ }^{\circledR}$ (número de acceso KF179047). Posee una longitud de 1803 nucleótidos y el marco de lectura abierto (ORF, del inglés open reading frame) codifica un precursor de 422 aminoácidos (Fig. 1.9 A).

La secuencia revela un total de 18 posibles neuropéptidos maduros, de acuerdo a la predicción de sitios de clivaje por endopeptidasas (Fig. 1.9 A). Quince de estos neuropéptidos son iguales en secuencia aminoacídica a los descriptos para la isoforma RhoprOKB (son codificados por los exones que comparten ambas isoformas) (Sterkel, Oliveira et al. 2012). Por otro lado, existen tres neuropéptidos que se encuentran presentes únicamente en la isoforma RhoprOKC (Fig. 1.9 B). Estos tres neuropéptidos no poseen dominios conservados característicos de RhoprOKA o RhoprOKB, ni de otros péptidos biológicamente activos. Por lo tanto, se los considera "péptidos espaciadores" según la definición previamente propuesta (Wegener and Gorbashov 2008). Por último, la isoforma RhoprOKC comparte dos exones con RhoprOKA, tres exones con RhoprOKB, y posee un exón único (Fig. 1.9 C).

Con el fin de determinar la expresión en los distintos tejidos de RhoprOKC se realizó RT-PCR utilizando como molde ADNc proveniente de SNC completo, ovarios $(\mathrm{OV})$, testículos $(\mathrm{T})$, intestino medio anterior (AM, del inglés anterior midgut), intestino medio posterior (PM, del inglés posterior midgut) y recto ( $\mathrm{HG}$, del inglés hindgut) de 
insectos adultos de $R$. prolixus. Mediante los métodos utilizados y la condición fisiológica seleccionada, RhoprOKC fue detectado únicamente en AM (Fig. 1.9 D).

Existen neuropéptidos que se expresan en mayor medida por fuera del SNC, por ejemplo, ETH se expresa principalmente en las células Inka ubicadas en el sistema traqueal de M. sexta (Zitnan, Kingan et al. 1996), o el péptido ILP 6 es sintetizado principalmente en el cuerpo graso, tanto en D. melanogaster como B. mori (Okamoto, Yamanaka et al. 2009; Okamoto, Yamanaka et al. 2009). Sin embargo, no existen antecedentes que péptidos que se expresen únicamente en intestino.

En insectos como D. melanogaster, L. migratoria, B. mori y Periplaneta americana se ha observado la expresión de números neuropéptidos en células endócrinas ubicadas en el epitelio del midgut: sulfakininas, CCAP, MIPs, Ast-A y C, sNPF, CCHa 1 y 2, DH 31, takinina, OKs (A y B) y leucomiosupresina (Sakai, Satake et al. 2006; Yamanaka, Roller et al. 2011; Veenstra and Ida 2014; Chen, Choi et al. 2015; Zels, Dillen et al. 2015; Wulff, Sierra et al. 2017). En R. prolixus particularmente, se detectó ya sea por IHQ, MS/MS o transcriptómica los siguientes neuropéptidos: CRF-símil DH, kinina, neuroparsina $\mathrm{A}, \mathrm{OKB} / \mathrm{OKC}$, miosupresina, $\mathrm{CCHa} 2, \mathrm{AKH} / \mathrm{CZ}$ péptido relacionados, Ast-A, proctolina e ILPs 2 y 6 (Te Brugge, Nassel et al. 2001; Te Brugge, Lombardi et al. 2005; Ons, Sterkel et al. 2011; Orchard, Lee et al. 2011; Santini, Ronderos 2009; Sterkel et al. 2010; Sterkel, Urlaub et al. 2011; Ricillo, Ronderos 2010; Zandawala, Lytvyn et al. 2012; Zandawala, Haddad et al. 2015; Wulff, Sierra et al. 2017).

Los neuropéptidos expresados en el intestino habitualmente regulan la contracción de la musculatura visceral, como por ejemplo, la miosupresina o proctolina (Orchard, Lee et al. 2011; Lee, Taufique et al. 2012), pero además, en muchos casos regulan la expresión de enzimas relacionadas con la digestión del alimento, como por ejemplo del tipo amilasas, proteasas o lipasas (Sakai, Satake et al. 2006). En insectos hematófagos como el caso de $R$. prolixus y el díptero Stomoxys calcitrans, se observó que la actividad de enzimas proteasas responde sólo en forma incipiente frente a una dieta no proteica, a base de polímeros o dímeros de glucosa como el dextran o la maltosa respectivamente (Garcia and Garcia 1977; Moffatt, Blakemore et al. 1995).

Por otra parte, en la cucaracha $P$. americana se determinó que la actividad de las enzimas del tipo $\alpha$-amilasa y proteasa se encuentra regulada por la liberación del 
péptido CCAP, el cual ajusta la actividad enzimática a nivel de tiempo y concentración. Además, se plantea la hipótesis que la regulación endócrina sobre la actividad enzimática le permite a insectos como los blatodeos poseer una dieta omnívora con un mayor rango de alimentos (Sakai, Satake et al. 2006).

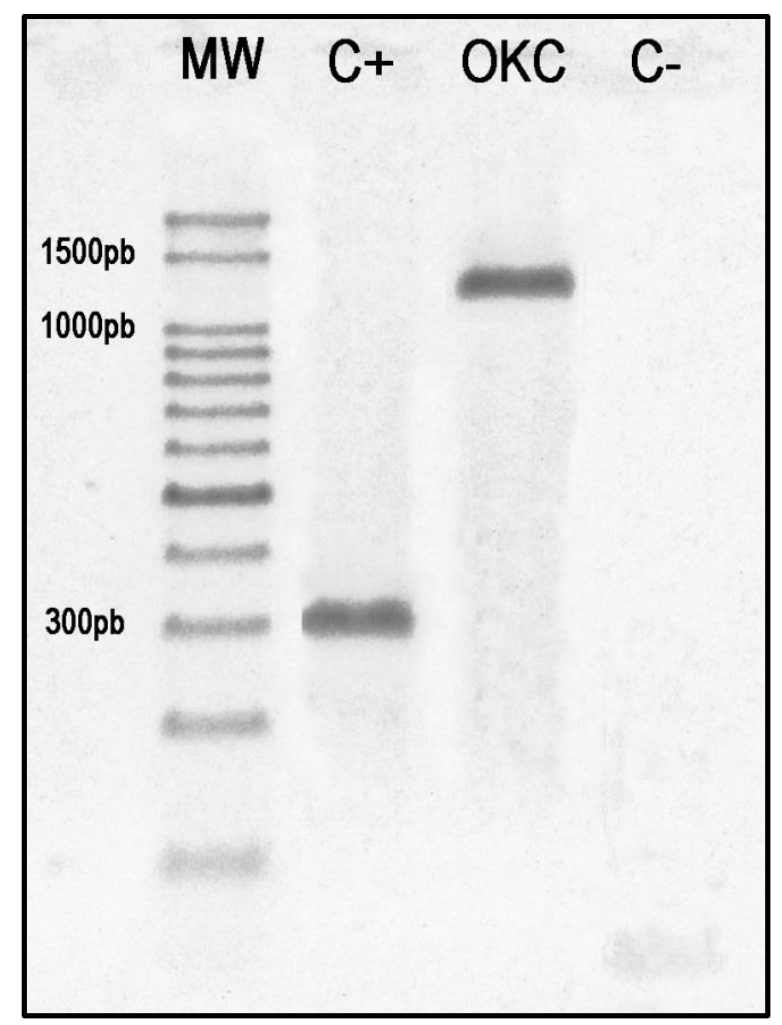

Figura 1.8: Race-PCR realizada sobre ADNc de ninfas de $5^{\circ}$ estadio de $R$. prolixus a fin de amplificar el transcripto de RhoprOKC. MW: marcador de peso molecular; $\mathrm{C}+$ : control positivo realizado con RhoprActin; OKC: PCR específica para RhoprOKC; C-: control negativo sin molde.

\section{Secuencia nucleotídica y aminoacídica de RhoprOKC A}

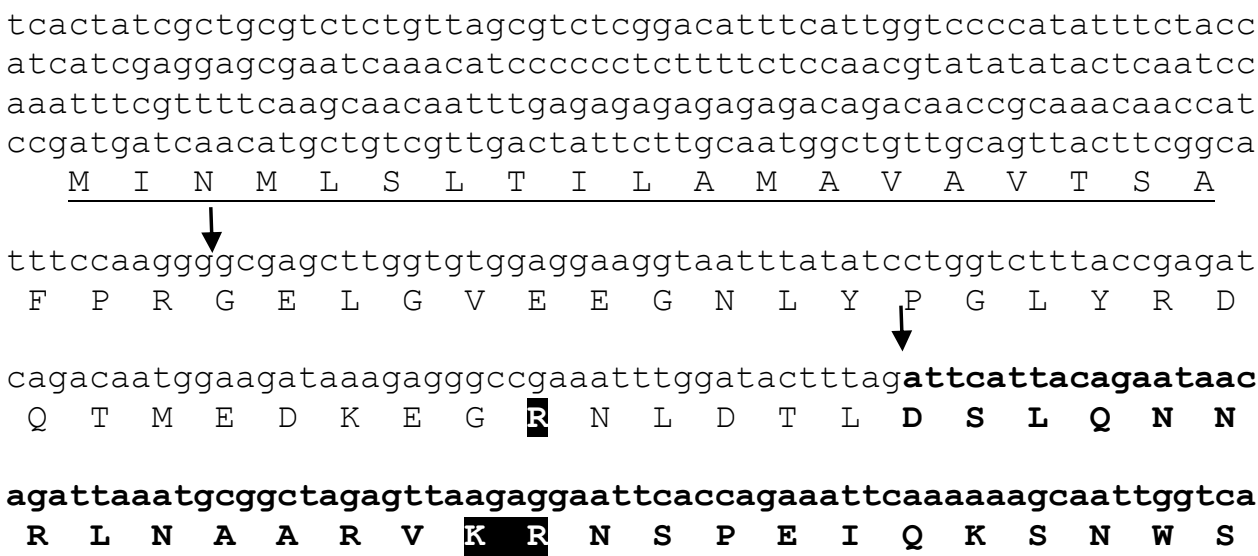


aaacgagacggtgttatcgtagagccaatctatggtctcagacccgataagaaggaaggc $\begin{array}{llllllllllllllllllll}\mathbf{K} & \mathbf{R} & \mathrm{D} & \mathrm{G} & \mathrm{V} & \mathrm{I} & \mathrm{V} & \mathrm{E} & \mathrm{P} & \mathrm{I} & \mathrm{Y} & \mathrm{G} & \mathrm{L} & \mathrm{R} & \mathrm{P} & \mathrm{D} & \mathbf{K} & \mathbf{K} & \mathrm{E} & \mathrm{G}\end{array}$

ggcacattggacagtcttggaggcggacatcttattagaaatctaaaagaaaacgaagac

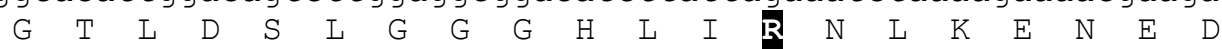

aattacgaacatgaaattaaaaagaagctttaaaaccaaatttcatacagatacaagt $\begin{array}{llllllllllllllllllll}\mathrm{N} & \mathrm{Y} & \mathrm{E} & \mathrm{H} & \mathrm{E} & \mathrm{I} & \mathbf{K} & \mathbf{K} & \mathrm{E} & \mathrm{A} & \mathrm{L} & \mathrm{K} & \mathrm{T} & \mathrm{K} & \mathrm{F} & \mathrm{H} & \mathrm{T} & \mathrm{D} & \mathrm{T} & \mathrm{S}\end{array}$

aagegtttttaccaaacaattgtcaaatacgaatcattttatttctaaagtttagaa $\begin{array}{llllllllllllllllllll}K & A & F & L & P & N & K & L & S & N & T & N & H & F & I & S & K & S & L & E\end{array}$

agtgttaatggtaggagcgaaattatggaccagcatttgttaagaaacttggtgtatggt $\begin{array}{llllllllllllllllllll}S & V & N & G & R & S & E & I & M & D & Q & H & L & L & R & N & L & V & Y & G\end{array}$

aaaggaagacgcttcaaacgtgatttcctggatggtttgggtggaggtcatttgctaaga

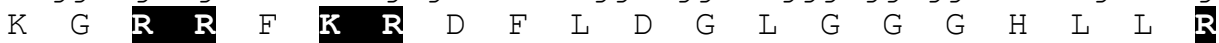

gataatattgatccatttgtggatgtccatcctgtgaaaggaacgagtaaaattccatat $\begin{array}{llllllllllllllllllll}\mathrm{D} & \mathrm{N} & \mathrm{I} & \mathrm{D} & \mathrm{P} & \mathrm{F} & \mathrm{V} & \mathrm{D} & \mathrm{V} & \mathrm{H} & \mathrm{P} & \mathrm{V} & \mathrm{K} & \mathrm{G} & \mathrm{T} & \mathrm{S} & \mathrm{K} & \mathrm{I} & \mathrm{P} & \mathrm{Y}\end{array}$ acaggcccaatatcttcagacggtgatcaacaggtgtctgtcaatttttcaaatggtaga

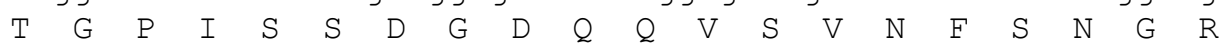
cattttgtaagagaatttttagacccattaggaggtggacatttaatcagaggaatagat

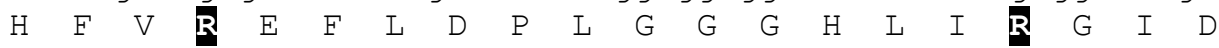

tccatagggggtggtcatttattaagaggattagatgctaaagagaatggaaatttagga

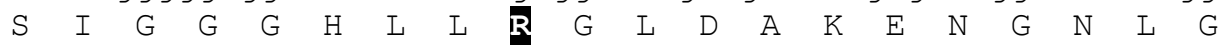

aaagaacttacggacggatttagaagtggttattccattagtggaggcccattagtaaga $\begin{array}{llllllllllllllllllll}K & E & L & T & D & G & F & \mathbb{R} & S & G & Y & S & I & S & G & G & P & L & V & R\end{array}$

gaattttggatccattaggtggaggtcatttaatcagaggattagattcaaaaagtggt

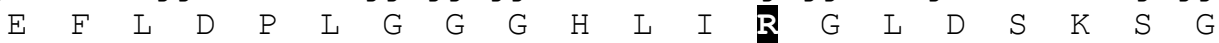

gatcattttaagagagaatttttagatccacttggaggtggtcatttaataagaggttta $\begin{array}{llllllllllllllllllllllll}D & H & F & K & \mathbf{R} & E & F & L & D & P & L & G & G & G & H & L & I & \mathbf{R} & G & L\end{array}$

gattccattggcggtggtcatttagtgagggaatttttggatccattaggtggaggtcat

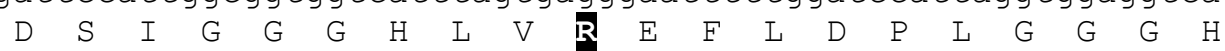

ttaatcagaggattagattccaaaggaggagatcattttaagagagaatttttagatcca

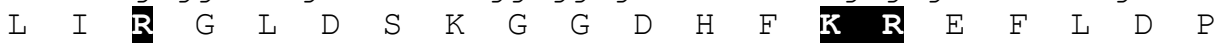

cttggaggcggtcatttaataagaggtttagattccattggtggtggtcatttagtgagg

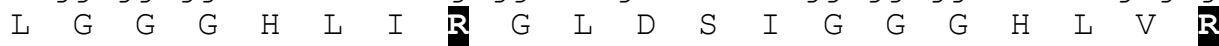
gagtttttggatccattaggaggtggtcatttaatcagaggattagattctgaaggtgac

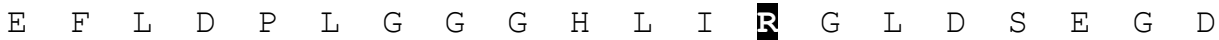

agtcatccttaggagatcattagaaattaatcaggacaatgtaatttaagactccatta $\mathrm{S} \mathrm{H} \mathrm{P}-$

aaaggcttttgggttcttaagagggagatatcttcttagaaataattaaatatagattg aacctaactaaaaccaactataatagcttttaatgcattattttccataacaatatcat tatgacatatttaaagcgcagcatttctggctacctcaaaaaactgaaattaaatctc agaatttaagatttccatgtgttttttatttacttaaaattttatgcattcatacaaa ttatatatattttttccatatattgtagctcattagtaataatataataataaaaccgc ttt 
Péptidos maduros propios de RhoprOKC B

RhoprOKC1: NLDTLDSLQNNRLNAARV $(2027.06 \mathrm{~m} / \mathrm{z})$

RhoprOKC2: NSPEIQKSNWS $(1289.61 \mathrm{~m} / \mathrm{z})$

RhoprOKC3: DGVIVEPIYGLRPD $(1542.82 \mathrm{~m} / \mathrm{z})$

Estructura génica de RhoprOKs C

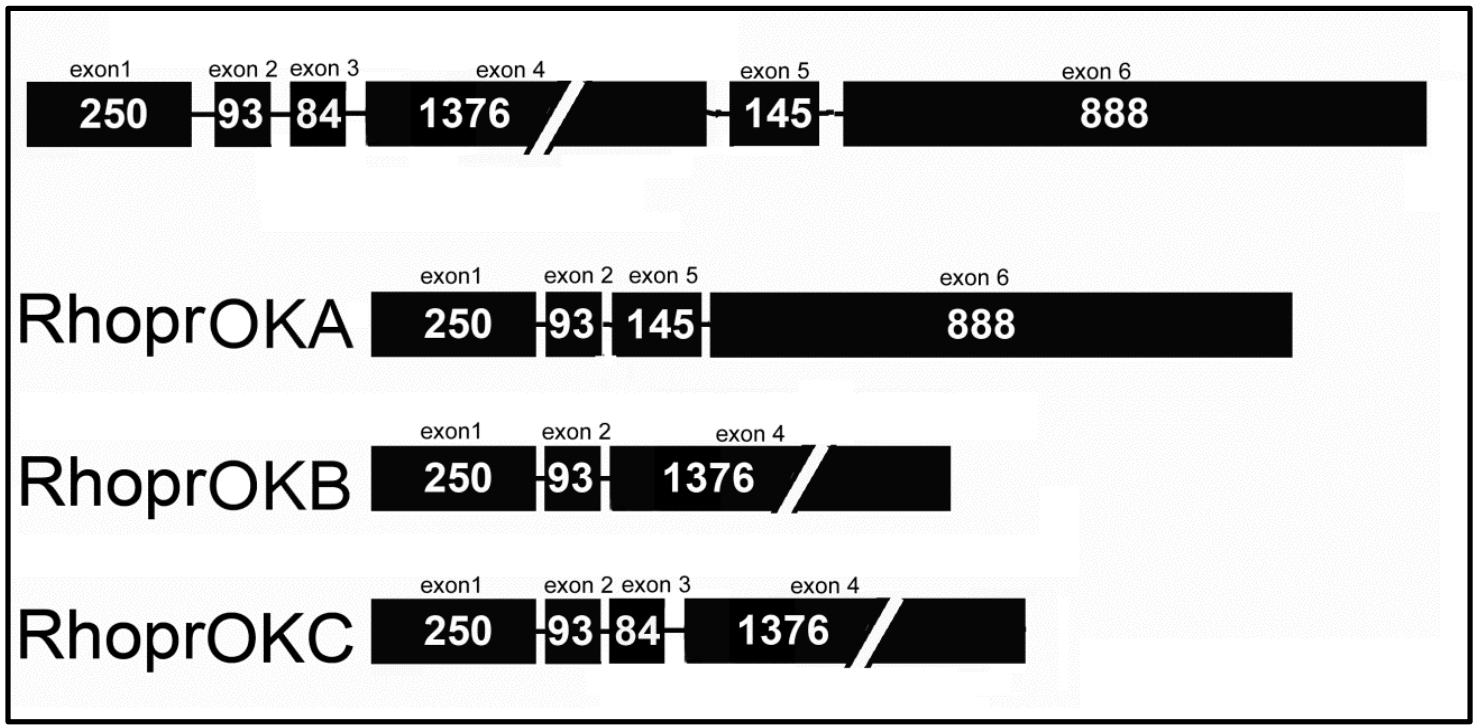

Patrón de expresión por tejidos de RhoprOKC D

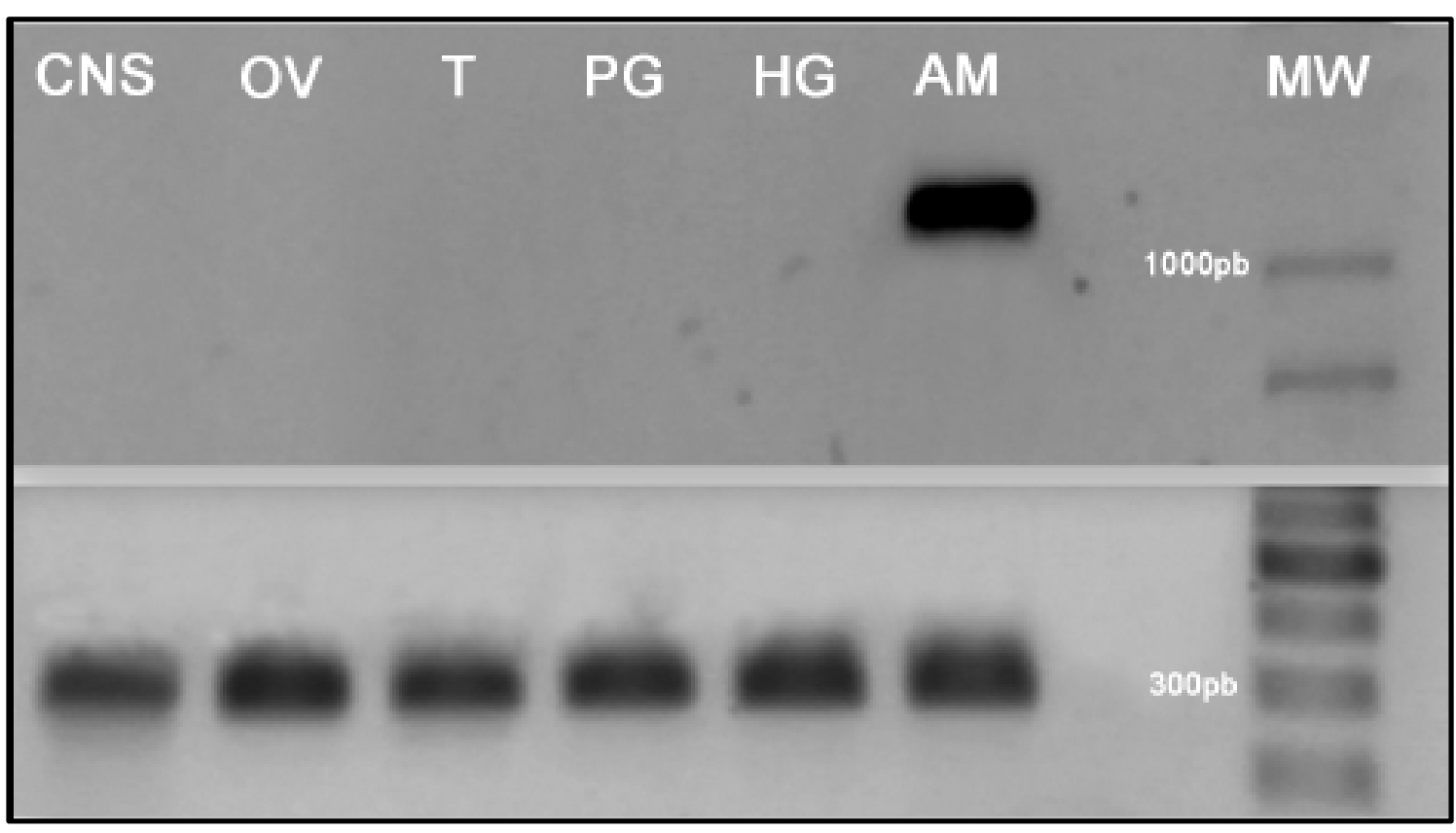

Figura 1.9: Secuencia, estructura y patrón de expresión de RhoprOKC. (A) Secuencia nucleotídica y aminoacídica completa del transcripto RhoprOKC. El péptido señal se encuentra subrayado, y las predicciones respecto a los sitios de clivaje proteolítico mono y dibásico se encuentran resaltadas en color 
negro. El exón y posibles péptidos maduros exclusivos de RhoprOKC se encuentran resaltados en negrita (la posición de los intrones se señala con flechas). (B) Péptidos maduros exclusivos de RhoprOKC, ausentes en RhoprOKA y RhoprOKB. (C) Estructura del gen precursor de Orcokinina y las 3 variantes de splicing Las líneas representan los intrones y los números la cantidad de bases por exón. (D) Patrón de expresión (Porción superior RhoprOKC, porción inferior RhoprActin).

\subsubsection{Inmunoreactividad para RhoprOKA en tejidos periféricos}

En un estudio previo de nuestro grupo de trabajo (Sterkel 2011) se determinó el patrón de expresión de RhoprOKA en SNC de R. prolixus. Debido a esto el presente trabajo se enfoca en el estudio de la expresión de OKA en órganos periféricos: AM; PM, HG, glándulas salivales (SG; del inglés salivary glands), cuerpo graso (FB; del inglés fat body), túbulos de Malpighi (MT; del inglés Malpighian tubes), ovario y testículos. Entre los tejidos analizados, se observó inmunoreactividad positiva en células del oviducto, testículos y proyecciones asociadas al vaso seminal (Fig. 1.10).

Existen numerosos péptidos para los cuales se ha detectado actividad sobre los tejidos asociados a las gónadas, sin embargo no en todos los casos se expresan específicamente en estos tejidos. Los péptidos con actividad endócrina sobre las gónadas pueden estar relacionados con la síntesis de ecdisona o de $\mathrm{JH}$ (factores reguladores de la ovogénesis) y acción sobre la musculatura visceral (Gilbert 2012). Por ejemplo, la hormona Ast-A, se sugiere como posible regulador de la síntesis de JH a nivel de la CA, e inhibe la contracción de los oviductos en $R$. prolixus (Sedra, Haddad et al. 2015; Zandawala and Orchard 2015). 


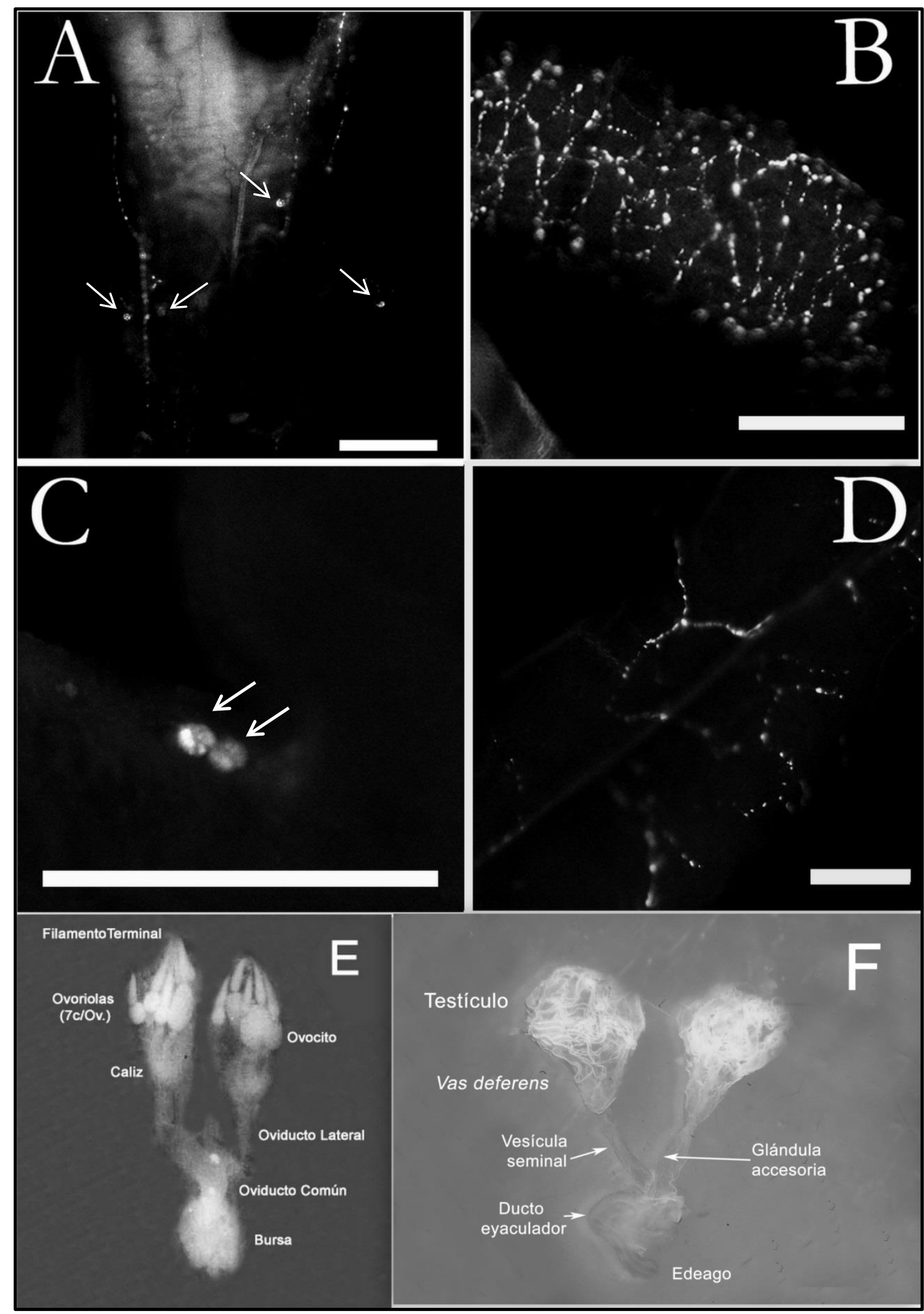

Figura 1.10: Inmunoreactividad positiva para OKA en tejidos periféricos de $R$. prolixus. (A) Proyecciones y células (fechas) sobre el oviducto común. (B) Inmunoreactividad para OKA asociada a proyecciones sobre el vaso seminal. (C) Células reactivas en testículo (flechas). (D) Proyecciones positivas para OKA sobre el testículo. (E) Ovario de $R$. prolixus sin marcación a modo de esquema. (F) Testículo de $R$. prolixus sin marcación a modo de esquema. Barra blanca: $100 \mu \mathrm{mts}$. 
Particularmente en $R$. prolixus, se han observado péptidos que actúan sobre la actividad de las gónadas, sin que sean sintetizados en estos tejidos: FLPs (FMRFa-like peptides) en el caso de los ovarios; pirokinina 1 (PK-1) en los testículos (Sevala, Sevala et al. 1992; Sedra and Lange 2014; Villalobos-Sambucaro, Lorenzo-Figueiras et al. 2015). Por otro lado, existen péptidos para los cuales se detectó su expresión en las gónadas de $R$. prolixus. Ya sea por IHQ, MS/MS o transcriptómica se observó la presencia de los siguientes neuropéptidos en ovario: AKH, FLPs (sólo procesos axonales), allatotropina (AT), Ast-A y C, ILPs 2, sNPF, NPLP1 (Zandawala, Lytvyn et al. 2012; Patel, Orchard et al. 2014; Sedra and Lange 2014; Ons 2017, VillalobosSambucaro 2016). Respecto a los testículos, se detectaron los péptidos: CT símil-DH, kinina, AT, CAPA- $\alpha$, ETH, CCAP (nueva isoforma a nivel de UTR, aún no caracterizada) ILPs 6, NPLP1 y proctolina (Paluzzi, Russell et al. 2008; Ons, Sterkel et al. 2011; Orchard, Lee et al. 2011; Bhatt, da Silva et al. 2014; Ons 2017).

Por otro lado, péptidos pertenecientes a la súper familia RFamida como por ejemplo la miosupresina (MS) y FMRFa-péptidos relacionados (FLPs) poseen acción antagónica sobre la contracción de la musculatura visceral de $R$. prolixus. La MS, si bien no afecta la contracción de tejidos asociados al ovario, inhibe la ovogénesis (Sedra and Lange 2014; Sedra and Lange 2016) y disminuye la contracción de la musculatura visceral del intestino medio y recto (Lee, Taufique et al. 2012). Sin embargo, los FLPs y el péptido sNPF, ambos estimulan la contracción de los tejidos asociados al ovario como oviductos y bursa, y a su vez la ovogénesis (Sedra and Lange 2014; Sedra and Lange 2016). Por otro lado, en B. mori se observó que todos estos péptidos están asociados a la disminución de la síntesis de ecdisteroides (Marchal, Vandersmissen et al. 2010; Yamanaka, Roller et al. 2011; Kaneko and Hiruma 2014).

Ensayos recientes de nuestro grupo de trabajo señalan actividad en la estimulación de la contracción aórtica para RhoprOKA y RhoprOKB, y de las contracciones peristálticas del intestino para OKB. Se observó un incremento en las contracciones aórticas de aproximadamente de un 20\% y 10\% (respecto de tejidos testeados con solución salina) para RhoprOKA y RhoprOKB respectivamente. Por otro lado, se observó un efecto conjunto en ensayos realizados con ambos péptidos en simultáneo, y se midió un incremento en la tasa de contracciones aórticas del 50\% (Wulff, Capriotti et al. 2018, manuscrito en revisión). El análisis de actividad miotrópica de OKA en buche e intestino de la cucaracha Blattella germanica reveló 
resultados negativos, lo cual coincide con nuestros resultados para RhoprOKA (Pascual, Castresana et al. 2004).

El rol relacionado con la ovogénesis para las orcokininas, propuesto en vista de su expresión en gónadas de $R$. prolixus, fue efectivamente observado en estudios realizados sobre $B$. germánica. Se silenció el gen de BlageOKs por RNAi y se observó una disminución significativa en el tamaño de los ovocitos, en la expresión de vitelogenina en cuerpo graso, y una disminución significativa de las proteínas ováricas (Ons, Belles et al. 2015). Por último, en el presente trabajo observamos un aumento en la síntesis de ecdisteroides frente al silenciamiento tanto de $\mathrm{OKA}$ como $\mathrm{OKB}$, indicando que las orcokininas podrían tener un rol inhibitorio de la síntesis de ecdisteroides (ver resultados Cap. 2).

Nuestros resultados y los antecedentes detallados con anterioridad sugieren un posible papel de las orcokininas en la regulación de la ovogénesis.

\subsubsection{Inmunoreactividad para RhoprOKB/C en $\mathrm{SNC}$ y tejidos periféricos}

El anticuerpo utilizado fue desarrollado sobre el péptido de secuencia EFLDPLGGGHLIC, presente en las isoformas RhoprOKB y RhoprOKC, por lo que se detecta la inmunoreactividad para ambas isoformas en simultáneo (OKBC-like inmunoreactivity; OBCLI). Los resultados indicaron que RhoprOKB/C posee una distribución más acotada que RhoprOKA tanto en cerebro como ganglios del SNC de $R$. prolixus ((Wulff, Sierra et al. 2017) y ver Figs. 1.4G: Introducción Cap.1 y 1.11A: este apartado), en concordancia con resultados publicados para D. melanogaster (Chen, Choi et al. 2015).

En el SNC, se detectó OBCLI en neuronas “reloj” (Vafopoulou and Steel 1996; Vafopoulou and Steel 2012), relacionadas con la regulación de ritmos circadianos, bilateralmente pareadas y ubicadas en el límite entre el protocerebro y los lóbulos ópticos (Fig. 1.11 B). Además, los márgenes posteriores y laterales del cerebro mostraron neuronas con evidencia de OBCLI (Fig. 1.11 B). Se detectó OBCLI en la corpora cardíaca (CC) (Fig. 1.11 C) sitio de liberación de neuropéptidos hacia la hemolinfa. En el ganglio sub-esofágico (SOG), detectamos una única neurona con OBCLI (Fig. 1.11 C). Esta célula se ubica en la parte posterior lateral, y envía una 
proyección hacia la parte anterior (Fig. 1.11 C). Aunque este patrón de expresión en células neurosecretoras no apareadas no suele observarse en insectos, se han obtenido resultados similares para OKB en D. melanogaster (Chen, Choi et al. 2015).

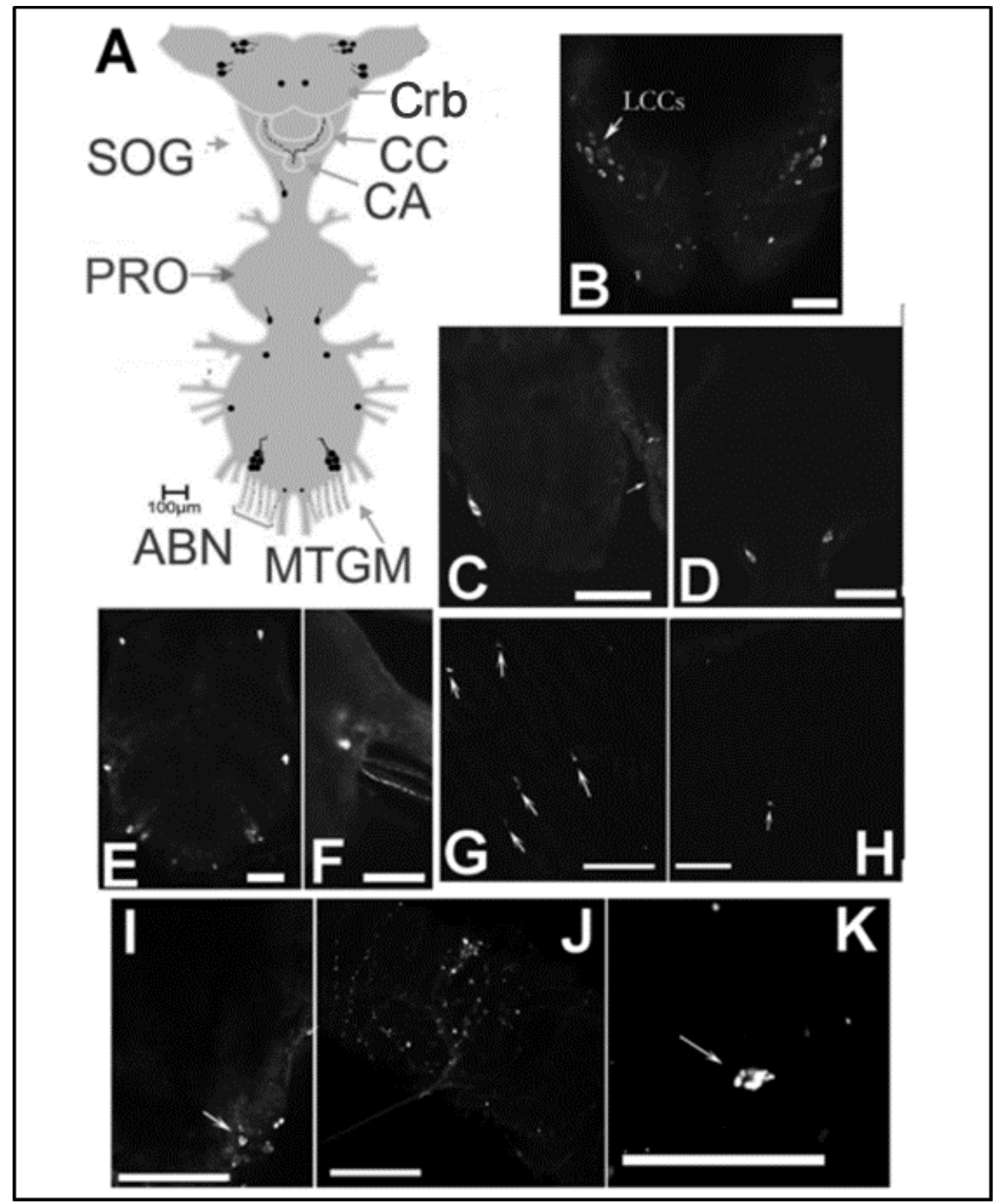

Figura 1.11: Inmunoreactividad positiva para RhoprOKB/CC (u OBCLI del inglés OKA-like inmunoreactivity). (A) Esquema representando las NSCs y sus procesos asociados más intensamente teñidos en el Cerebro (Crb), SOG, PTG, MTGM, CC, CA y ABNs. (B) Vista dorsal del Cerebro: Se observa OBCLI en las células laterales circadianas o de "reloj" (LCCs del inglés Lateral Clock Cells). (C) Vista dorsal del SOG y CC (flecha). (D) PTG. (E) MTGM. (E y F) Detalle de un grupo de células neurosecretoras posteriores en MTGM y ABNs. (G) Detalle de OBCLI en NSCs de Midgut anterior 
(flecha). (H) Detalle de OBCLI en NSCs de Midgut posterior (flecha). (I) Células laterales reactivas del Oviducto (flecha). (J) Células reactivas de procesos asociados al Vaso Seminal del Testículo. (K) OBCLI observada en célula reactiva del Testículo (flecha). La barra indica $100 \mu \mathrm{mts}$.

En el ganglio protoráxico se detectaron dos neuronas pareadas en el margen posterior lateral, las cuales enviaban proyecciones anteriores (Fig. 1.11 D). Por otro lado, en el ganglio meso-metatorácico se observó intensa marcación en 16 células pareadas, las cuales se encontraban dispuestas en grupos de pares en tres diferentes áreas: margen anterior, región media lateral y región posterior, tanto a izquierda como a derecha del MTGM (Fig. 1.11 E). Finalmente respecto al par de neuronas ubicadas en la zona posterior del MTGM, se observó marcación en proyecciones posteriores ubicadas entre estas células y los ABNs 1 y 2 (Fig. 1.11 E y F).

A nivel periférico, se detectó OBCLI en numerosas células de tipo endocrino distribuidas a lo largo del AM (Fig. 1.11 G), y un número menor en el PM (Fig. 1.11 H). Este patrón de expresión es coincidente con los reportes observados previamente en D. melanogaster (Veenstra and Ida 2014; Chen, Choi et al. 2015) y discordantes con lo informado para T. castaneum, donde tanto OKB como OKA fueron detectados en el AM pero no en PM (Jiang, Kim et al. 2015).

Se observó OBCLI en los ovarios, puntualmente en el oviducto lateral (Fig. 1.11 I). Además se detectó marcación positiva OBCLI en testículos (Fig. $1.11 \mathrm{~J}$ y K) y células asociadas al vaso seminal (Figs. $1.11 \mathrm{~J}$ y K). En contraposición no se observó OBLI en los tejidos periféricos HG, GS, FB ni MT. Los resultados obtenidos en los ensayos de inmunohistoquímica son consistentes con lo observado para otras especies de insectos (Yamanaka, Roller et al. 2011; Chen, Choi et al. 2015; Jiang, Kim et al. 2015).

La expresión en células laterales de reloj es un indicio de una posible función de las $\mathrm{OKs}$ en procesos regulados de manera circadiana, tales como la muda y la ecdisis (Hofer and Homberg 2006; Vafopoulou, Steel et al. 2007; Vafopoulou, Terry et al. 2010; Vafopoulou and Steel 2012). Para la cucaracha L. maderae se describió un papel de OKA en la regulación de la actividad locomotora circadiana.

Nuestros resultados permitieron caracterizar el patrón de expresión de las OKs en $R$. prolixus, e identificar una nueva isoforma para este gen: "OKC", única especie para la cual se han identificado tres isoformas del gen OKs hasta el momento. 
Finalmente, como se discutió al comienzo del presente apartado, OKC es el primer péptido detectado exclusivamente en intestino. Dado este patrón de expresión particular, proponemos que su función se encuentra asociada a procesos digestivos, como contracción de la musculatura visceral y regulación enzimática. Sin embargo, este resultado debe ser testeado y confirmado bajo otras condiciones fisiológicas y estadios de desarrollo.

Culminada esta primera etapa de identificación y patrón de expresión, futuros ensayos funcionales permitirán dirimir el rol funcional específico de OKC. 


\subsection{CONCLUSIONES}

En el presente Capítulo:

* Existe una tercera isoforma para el gen precursor de OKs en insectos.

* El gen RhoprOK poseen un patrón de expresión asociado a cada isoforma.

De acuerdo al patrón de expresión del gen RhoprOK, y los antecedentes previos, se plantea la posibilidad que este gen este asociado funcionalmente a procesos tales como:

$>$ Regulación de ritmos circadianos.

$>$ Ingesta de alimento.

$>$ Ovogénesis y reproducción.

$>$ Ecdisis.

$>$ Síntesis de ecdisteroides. 
CAPITULO II

\section{Estudio de la regulación endócrina del ciclo de muda de Rhodnius prolixus}

\subsection{INTRODUCCIÓN}

\subsubsection{Ciclo de vida de los insectos}

De acuerdo al tipo de desarrollo post-embrionario, los insectos se clasifican en tres grupos: ametábolos, hemimetábolos y holometábolos (Resh 2009). Los ametábolos se caracterizan por no experimentar metamorfosis a lo largo de su ciclo de vida y los insectos recién eclosionados poseen una estructura corporal similar a la de los adultos. Este ciclo de vida se identifica por el aumento gradual de tamaño a través de los estadios inmaduros (generalmente cinco), y aumento progresivo de las piezas de la genitalia, hasta alcanzar las características del adulto. Reconocemos esta estrategia de desarrollo post-embrionario en órdenes como Diplura, Tisanura, Colémbolla y Protura (Resh 2009; Belles 2011). Este tipo de desarrollo es considerado ancestral, similar al que poseían los organismos antecesores de los insectos (Houseman 2007). Un ejemplo representativo de este grupo es el tisanuro, comúnmente conocido como pececillo de plata, Lepisma saccharina (Fig. 2.1). 


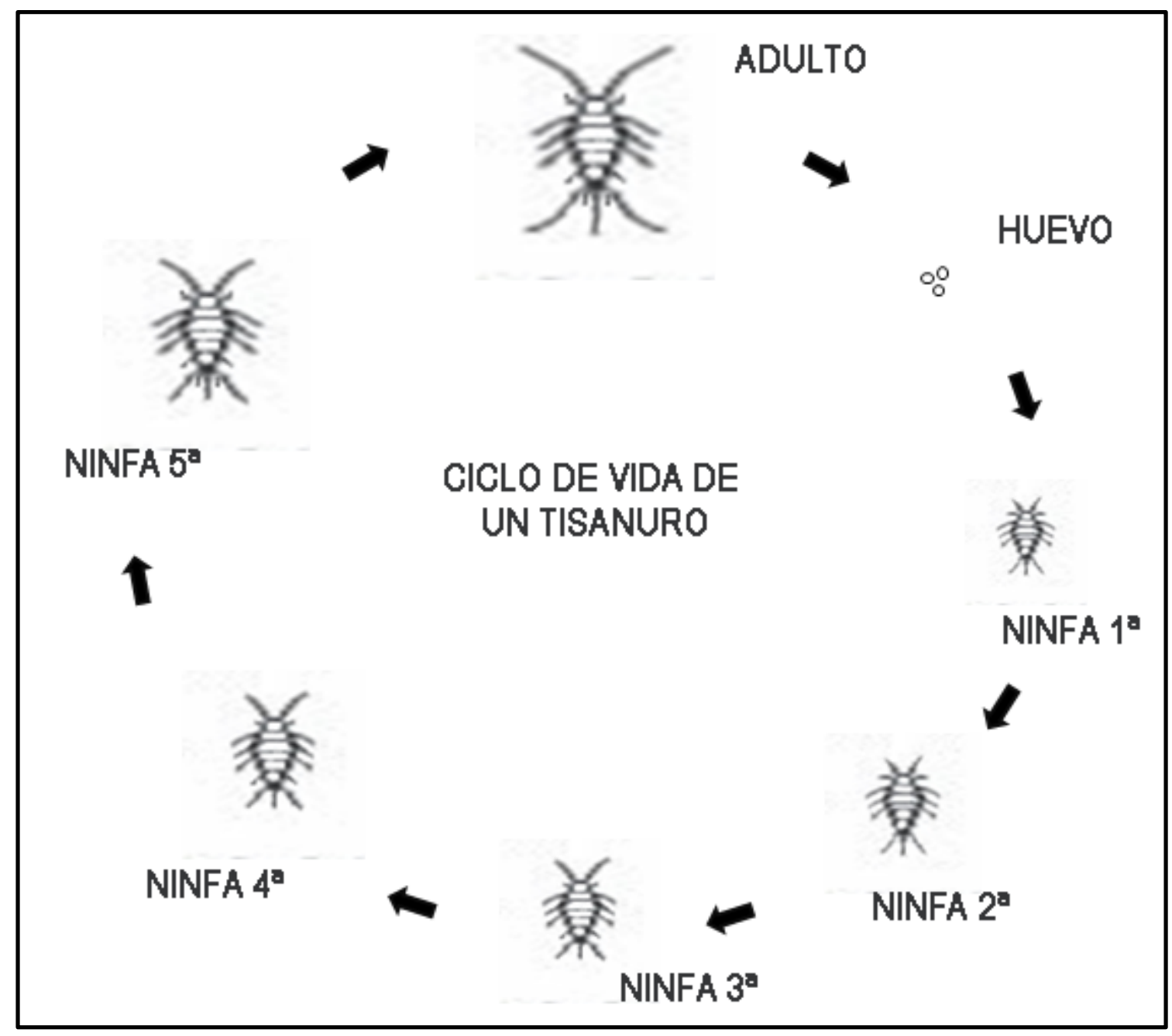

Figura 2.1: Esquema del ciclo de vida del insecto ametábolo tisanuro L. saccharina .

Los hemimetábolos por otra parte, se caracterizan por poseer una metamorfosis parcial a lo largo de los estadios inmaduros. Este tipo de metamorfosis implica cambios graduales (por ejemplo aparición de esbozos alares externos en los últimos estadios ninfales) y aumento progresivo del tamaño corporal. Los estadios ninfales son similares al adulto; como éste, poseen ojos compuestos y patas completamente desarrolladas. Sin embargo, a diferencia del adulto no poseen alas (en las especies aladas), ni órganos sexuales maduros. Reconocemos este tipo de ciclo de desarrollo en órdenes como por ejemplo Hemiptera, Ortóptera y Blatodea (Resh 2009; Belles 2011). Los hemimetábolos, al igual que holometábolos, se caracterizan en general por la conjunción del estadio adulto reproductivamente maduro y la presencia de alas (van Emden 2007; Resh 2009). Un ejemplo de este grupo lo constituye el insecto triatomino R. prolixus, organismo de estudio del presente trabajo (Fig. 2.2). 


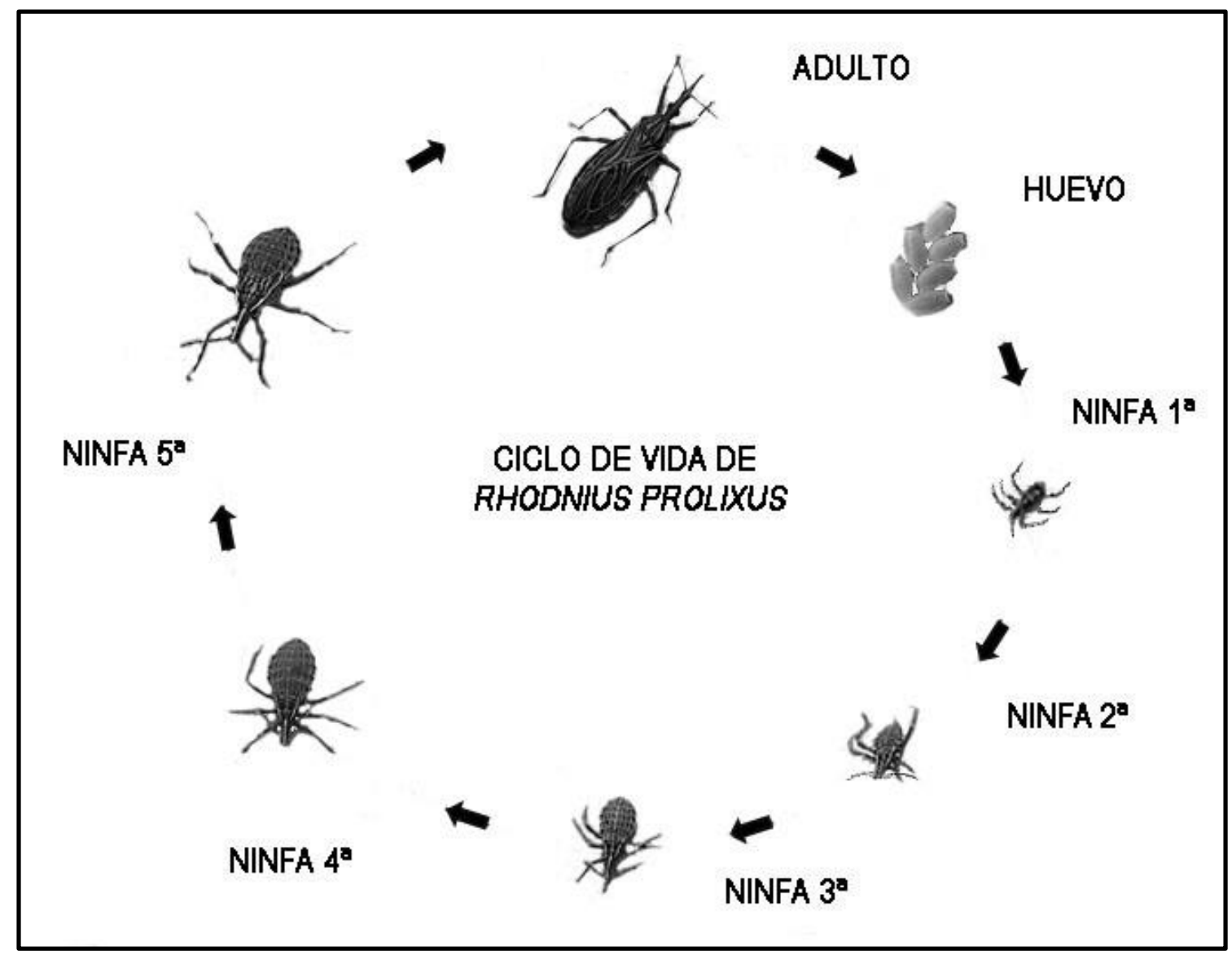

Figura 2.2: Esquema del ciclo de vida del insecto hemimetábolo Rhodnius prolixus.

Los holometábolos se caracterizan por poseer una metamorfosis completa, al atravesar los estadios inmaduros de larva, pupa y finalmente adulto. Se los denomina también endopterigotas, dado que los esbozos alares en los estadios inmaduros se ubican por dentro del cuerpo (Brusca 1990). Existen distintos tipos de larvas y pupas en los distintos órdenes, asociados en cada caso al ambiente y la forma de alimentación. Existen larvas de vida libre o que se hayan dentro de un organismo huésped, móviles, inmóviles, etc. (Resh 2009; Belles 2011). Respecto al estadio de pupa, si bien habitualmente constituye una fase inmóvil, existen ejemplos de pupas móviles (en general acuáticas), por ejemplo es el caso de dípteros de las familias Culicidae y Chironomidae (Brusca 1990). Durante este estadio se produce una reorganización total de los tejidos, apoptosis, perdida de tejidos y formación de los nuevos órganos pertenecientes al adulto. Esto incluye por ejemplo: formación y crecimiento de las alas, desarrollo de los músculos del vuelo y la genitalia. Se clasifica a las pupas en dos 
grandes grupos: obtecta (con apéndices bucales y locomotores fusionados al cuerpo), o exarada (con apéndices libres) (Resh 2009; Belles 2011). Dada la fragilidad de este estadio, muchas pupas se encuentran protegidas en una estructura construida a partir de uno o varios elementos según la especie, como por ejemplo: seda, ceras, quitina, heces, detritos del suelo y materia vegetal (Resh 2009; Belles 2011). Un ejemplo de ciclo de vida holometábolo es el insecto himenóptero Apis mellifera (abeja de la miel) (Fig. 2.3).

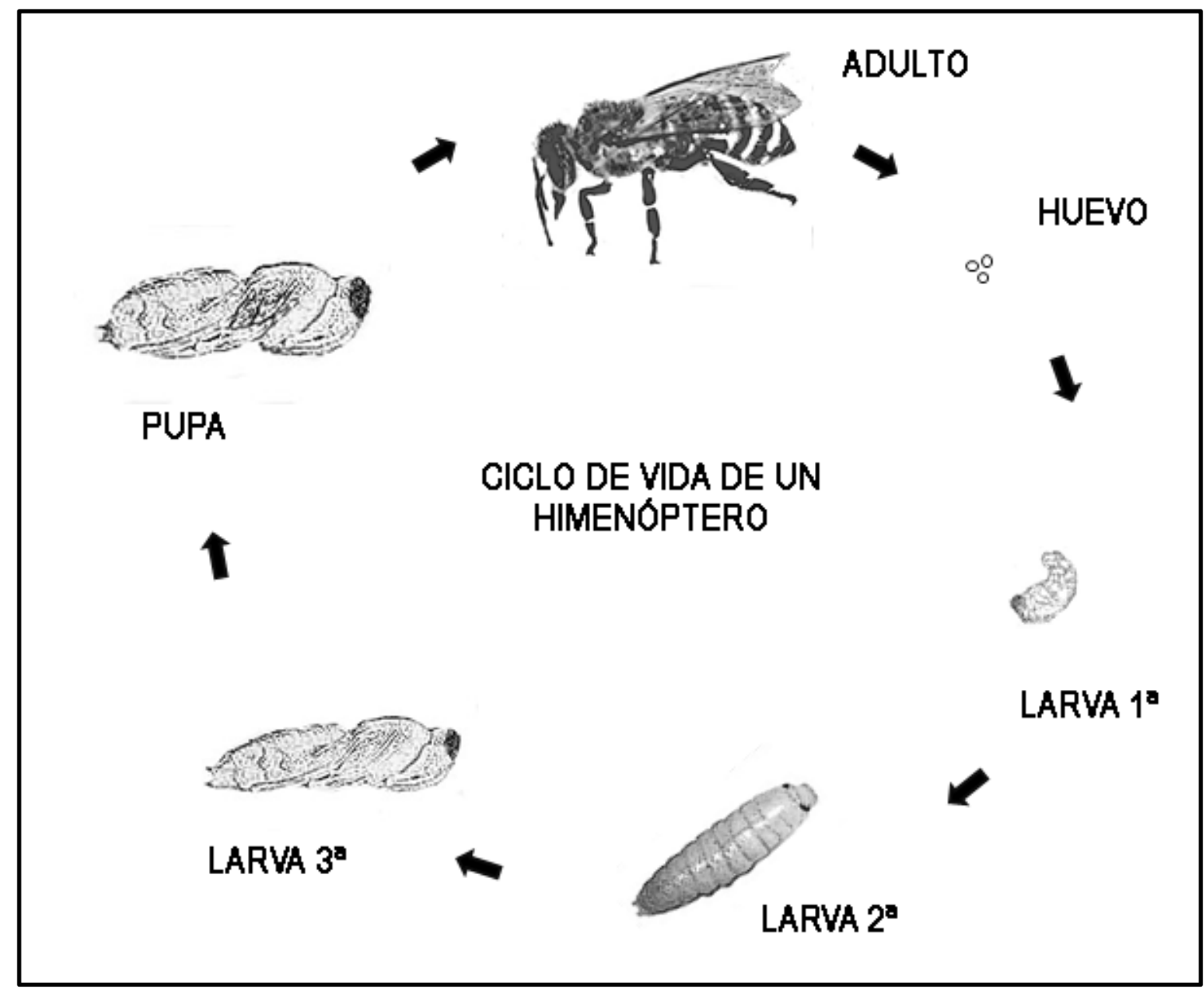

Figura 2.3: Esquema del ciclo de vida del insecto holometábolo A. mellifera. 


\subsubsection{El proceso de muda: etapas y regulación endócrina}

Para crecer y desarrollarse a través de sus estadios inmaduros, y finalmente alcanzar el estadio adulto, todos los artrópodos están condicionados al reemplazo de su exoesqueleto. Esta estructura rígida les permite sostén, locomoción y los protege de los factores físicos y biológicos del ambiente. Durante el desarrollo post-embrionario del insecto, la cutícula es reemplazada en el traspaso de un estadio al siguiente, en un proceso denominado muda, el cual culmina con la ecdisis (Chang 1993; Gilbert, Rybczynski et al. 2002; Mesce and Fahrbach 2002). El ciclo de muda suele iniciarse inmediatamente después de la ecdisis del estadio anterior, con la alimentación y el crecimiento tisular constante (Gilbert 2012). Sin embargo, en insectos con hábitos alimenticios periódicos, como $R$. prolixus, el proceso de muda permanece arrestado hasta una ingesta abundante de alimento (Wigglesworth 1934).

En $R$. prolixus, tras la ingesta se inicia un aumento progresivo de la concentración hemocélica de ecdisteroides. Este incremento continúa hasta alcanzar un punto máximo en un día específico para cada estadio ninfal, a partir del cual comienza a declinar y da inicio al proceso de pre-ecdisis. Si bien ha sido medido sólo en ninfas de $4^{\text {to }}$ y $5^{\text {to }}$ estadio, esta variación se encuentra correlacionada con la longitud del ciclo comprendido entre la ingesta y la ecdisis, el cual es específico a su vez para cada estadio ninfal (Wulff, Sierra et al. 2017). En las ninfas de $4^{\text {to }}$ estadio, en la que se han desarrollado la mayoría de los experimentos de esta Tesis, el pico de ecdisona ocurre en el día 6 post-ingesta (PBM, del inglés post blood meal) (Wulff, Sierra et al. 2017), mientras que en el último (V) estadio, el pico de ecdisona se produce hacia el día 13 PBM (Vafopoulou and Steel 1989).

La $\mathrm{E}$ es una pro-hormona de tipo esteroide que actúa a través de su receptor como factor de transcripción de numerosos genes asociados a la muda y ecdisis en todos los artrópodos. Su principal forma activa y circulante en hemolinfa se oxida por adición de un grupo $-\mathrm{OH}$ para originar la 20-Hidroxi-Ecdisona (20E). La síntesis de E se restringe a las glándulas protoráxicas en estadios inmaduros (glándulas de anillo en dípteros) y a las gónadas en adultos (de Loof 1984). La conversión a la forma activa (20E), se produce en tejidos periféricos tales como el cuerpo graso y epidermis (King and Siddall 1969). Los esteroides provienen de la dieta (fitoesterol o colesterol) y son sometidos a mono-oxidaciones sucesivas por parte de enzimas citocromo P450s 
codificadas en los genes Halloween (Vafopoulou and Steel 2005; Hentze, Moeller et al. 2013; Niwa and Niwa 2014).

Se han identificados varios neuropéptidos con actividad ecdisteroidogénica positiva o negativa. Por ejemplo, los péptidos similares a insulina (ILP 6), la hormona protoraxicotrópica (PTTH; del inglés prothoracicotropic hormone), y péptidos tipo FXPRL-amida regulan en forma positiva la síntesis de E (Nagasawa, Kataoka et al. 1984; Kataoka, Nagasawa et al. 1991; Watanabe, Hull et al. 2007). Por otro lado, neuropéptidos tales como la miosupresina (MS; del inglés myosuppressin), allatostatina B (MIPs; del inglés myoinhibitory peptides) y la hormona protoráxico estática (PTSP; del inglés prothoracicostatic peptide), disminuyen la síntesis de ecdisteroides (Hua, Tanaka et al. 1999; Tanaka and Yukuhiro 1999; Yamanaka, Hua et al. 2005; Yamanaka, Roller et al. 2011). Sin embargo, no todos los sistemas neuropeptídicos poseen una función conservada en las distintas especies de insectos. Por ejemplo, PTTH, hormona central en la regulación de la síntesis de ecdisona en holometábolos, al momento sólo sido confirmada en los hemípteros Nilaparvata lugens y Lygus hesperus (Tanaka, Suetsugu et al. 2014; Tassone, Geib et al. 2016).

Además de la ecdisona, la hormona juvenil ( $\mathrm{JH})$ es otra hormona no peptídica central en la regulación del crecimiento y metamorfosis de los insectos. Se ha reportado en observaciones realizadas en los insectos B. mori y Pyrrhocoris apterus, que la JH no es esencial en el proceso de muda entre los dos primeros estadios ninfales pero sí entre los siguientes estadios (Smykal, Bajgar et al. 2014). En T. castaneum y R. prolixus, se observó que el silenciamiento transcripcional (RNAi) del receptor de la JH (gen de tolerancia al metopreno), conducía a alteraciones metamórficas. Particularmente en $R$. prolixus se observaron estadios adultoides con alas y genitalia subdesarrolladas en ninfas de $5^{\text {to }}$ estadio, propios de la ausencia de JH (Konopova and Jindra 2007; Villalobos-Sambucaro, Riccillo et al. 2015).

La JH fue identificada (como un factor regulador de la ecdisis) por primera vez en insectos a partir de la Corpora Allata (CA) de R. prolixus, (Wigglesworth 1948). Posteriormente, con su caracterización a nivel de estructura, se determinó que la JH es una familia de moléculas agrupadas por similitud en su estructura química. La forma más habitual entre los insectos es la JH III, pero existen formas adicionales entre los lepidópteros: JH 0, JH I y 4-methil JH I, y en dípteros y algunos hemípteros, las formas 
JH III doble-epóxido 65 y 25 respectivamente (Goodman \& Granger, 2005). En todas sus variantes, esta hormona se sintetiza en la CA a partir del farnesol, el cual deriva a su vez de una modificación progresiva y fosforilación del acetil CO-A (Hiruma 2013). Por último, la concentración de la JH en hemolinfa está regulada por múltiples factores internos y externos. El aumento y disminución de su síntesis está regulada por neuropéptidos como la allatotropina (AT) y allatostatina B (Ast-B) respectivamente, en ciertos lepidópteros y ortópteros estudiados (Lorenz, Kellner et al. 1995; Yamanaka, Yamamoto et al. 2008). Sin embargo, en B. germánica y D. melanogaster, se observó que la Ast-B no inhibe la síntesis de JH. En D. melanogaster incluso no se haya presente el gen que codifica AT (Maestro and Belles 2006; Weaver and Audsley 2009).

Además, se ha demostrado acción trópica sobre la síntesis de JH por parte de la hormona desencadenante de la ecdisis (ETH, del inglés ecdysis triggering hormone), la 20E, el AMPc, las aminas biogénicas y la propia JH. Como contraparte, acción inhibitoria del péptido sNPF (Granger, MacDonald et al. 1994; Stay and Tobe 2007; Weaver and Audsley 2009; Meiselman, Lee et al. 2017).

El aumento en la concentración hemocélica de 20E desencadena un incremento en la transcripción del precursor del neuropéptido ETH, que se expresa en las células endócrinas Inka alojadas en glándulas epitraqueales (Zitnan, Kingan et al. 1996). En forma simultánea aumenta la expresión de los dos receptores de ETH (R-ETHA y RETHB) en el SNC (Zitnanova, Adams et al. 2001; Kim, Zitnan et al. 2006). Sin embargo, la liberación de esta hormona al hemocele, al igual que otras hormonas como la corazonina y la hormona de la eclosión, se produce a medida que la concentración de 20E en hemolinfa disminuye (Schwartz and Truman 1982; Zitnanova, Adams et al. 2001; Kim, Zitnan et al. 2006). En este contexto físiológico se inicia el proceso de ecdisis, el cual se divide en tres etapas: pre-ecdisis, ecdisis y post-ecdisis. La ecdisis posee un punto de inicio y una duración variable por especie. La regulación hormonal de este mecanismo ha sido caracterizado en forma completa únicamente para insectos holometábolos, principalmente el díptero D. melanogaster y los lepidópteros Manduca sexta y B. mori (Kim, Zitnan et al. 2006; Zitnan, Kim et al. 2007; Arakane, Li et al. 2008). Sin embargo, se han realizado observaciones acerca de las características comportamentales y tiempo de duración de la ecdisis en insectos de diferentes órdenes. Por ejemplo, la ecdisis completa tiene una duración aproximada de $2 \mathrm{hs}$ en $D$. melanogaster, 5,5hs para M. sexta, 12,5hs en $T$. castaneum y 6 hs en $R$. prolixus 
(Hughes 1980; Ampleford and Steel 1982; Truman 2005; Kim, Zitnan et al. 2006; Arakane, Li et al. 2008; Gilbert 2012; Lee, Orchard et al. 2013).

La pre-ecdisis en insectos posee dos características principales. La primera es la sucesión de acciones, como por ejemplo contracciones rítmicas y movimientos estereotipados con el fin de romper las conexiones entre la musculatura y la cutícula a desechar (Fig. 2.4). Los insectos holometábolos fijan su cutícula al sustrato para favorecer la separación entre ambas cutículas debido a contracciones rítmicas de los músculos abdominales. Con el mismo objetivo, los insectos hemimetábolos realizan movimientos estereotipados e ingesta de aire por la probóscide desde el inicio de la preecdisis, lo cual aumenta la presión interna sobre la cutícula a desechar (Fig. 2.4) (Hughes 1980; Ampleford and Steel 1982; Gammie and Truman 1997; Peabody, Pohl et al. 2009; Lee, Orchard et al. 2013).

La ecdisis comienza con la apertura de la línea ecdisial (ECL; del inglés ecdysial line). Simultáneamente se inicia el ingreso de aire al nuevo sistema traqueal (Fig. 2.4). Esto último se produce como consecuencia de que los nuevos espiráculos comienzan a ser funcionales a medida que ambas cutículas se separan. Esta etapa es la más crítica del proceso, dado que el insecto en un tiempo breve debe desechar la antigua cutícula antes de que la nueva comience el proceso de endurecimiento. Si la nueva cutícula se endurece prematuramente el insecto no sólo no logra desechar la antigua, sino que además no se completa el correcto inflado de las distintas estructuras corporales por presión de aire, como por ejemplo las alas (en caso de muda a estado adulto). El insecto en esta etapa es especialmente vulnerable al ataque de otro organismo (parásito o predador) dado que la cutícula en este periodo no constituye una barrera física de defensa (Hughes 1980; Ampleford and Steel 1982; Gammie and Truman 1997; Peabody, Pohl et al. 2009; Lee, Orchard et al. 2013).

Durante la post-ecdisis ocurre el aumento de tamaño corporal en la mayor medida posible que lo permita la nueva cutícula. Este, es un requerimiento necesario para todos los artrópodos dado que estos poseen exoesqueleto. Esta expansión resultado de la elevada presión interna, provee el espacio suficiente para el posterior crecimiento tisular durante el siguiente estadio de desarrollo. Además, el ingreso de aire por la probóscide y el sistema traqueal, genera la presión interna adecuada para la correcta expansión de estructuras tales como antenas, patas y alas (Fig. 2.4). Por último, una 
señal endócrina, principalmente mediada por la proteína bursicon (BUR), determina el endurecimiento y melanización de la nueva cutícula una vez que ha alcanzado su forma adecuada (Hughes 1980; Ampleford and Steel 1982; Gammie and Truman 1997; Mesce and Fahrbach 2002; Truman 2005; Peabody, Pohl et al. 2009; Lee, Orchard et al. 2013).

\begin{tabular}{|c|c|c|c|}
\hline \multirow[b]{2}{*}{ Holometábolos } & \multicolumn{3}{|c|}{$\begin{array}{l}\text { Firaliza atsorción de líquidos; Firaliza emergencia de a cutícula } \\
\text { apertura línea eodisial }\end{array}$} \\
\hline & Pre-Ecdisis & Ecdisis & Post-Ecdisis \\
\hline $\begin{array}{c}\text { M. Sext's } \\
\text { (lepidóptero) }\end{array}$ & $\begin{array}{c}\text { Sujeción cuticular al sustrato; } \\
\text { contracciones dorsoventrales } \\
\text { abdominales; comienza inflado } \\
\text { de nuevas tráqueas }\end{array}$ & $\begin{array}{c}\text { Contracciones peristálticas; } \\
\text { comienzo extensión alar; } \\
\text { finaliza inflado de nuevas } \\
\text { tráqueas }\end{array}$ & $\begin{array}{l}\text { Sujeción tarsal al sustrato; } \\
\text { expansión alar y corporal por } \\
\text { presión de aire traqueal y } \\
\text { digestiva; rotación alar; } \\
\text { endurecimiento y melanización }\end{array}$ \\
\hline $\begin{array}{l}\text { D. Melsnogester } \\
\text { (díptero) }\end{array}$ & $\begin{array}{c}\text { Sujeción cuticular al sustrato; } \\
\text { contracciones abdominales } \\
\text { antero posteriores; expansión } \\
\text { cefálica }\end{array}$ & $\begin{array}{l}\text { Contracciones peristáticas; } \\
\text { expansión del ptilinum; } \\
\text { contracciones cefálicas anteriores } \\
\text { inflado de nuevas tráqueas; } \\
\text { locomoción }\end{array}$ & $\begin{array}{c}\text { Locomoción; expansión alar y } \\
\text { corporal por presión de aire } \\
\text { traqueal y digestiva; } \\
\text { contracción abdominal; } \\
\text { endurecimiento y } \\
\text { melanización }\end{array}$ \\
\hline $\begin{array}{l}\text { I Gastaneum } \\
\text { (coleóptero) }\end{array}$ & $\begin{array}{c}\text { Sujeción cuticular al sustrato; } \\
\text { contracciones dorsoventrales } \\
\text { abdominales }\end{array}$ & $\begin{array}{l}\text { Contracciones peristálticas; } \\
\text { movimientos dorso ventrales } \\
\text { corporales; expansión de alas }\end{array}$ & $\begin{array}{l}\text { Sacudidas corporales; } \\
\text { retracción alar; } \\
\text { endurecimiento y }\end{array}$ \\
\hline Hemimetábolos & & & melanizacion \\
\hline $\begin{array}{l}\text { 5. Gregsis } \\
\text { (ortóptero) }\end{array}$ & $\begin{array}{l}\begin{array}{c}\text { Sujeción tarsal al sustrato; } \\
\text { lenta toma de aire por } \\
\text { digestivo; compresión } \\
\text { abdominal }\end{array} \\
\text { Movimientos antenales (Sconning }\end{array}$ & $\begin{array}{c}\text { Sujeción al sustrato con los } \\
\text { tarsos; rápida toma de aire } \\
\text { por digestivo; compresión } \\
\text { abdominal }\end{array}$ & $\begin{array}{c}\text { Sujeción tarsal al sustrato; } \\
\text { expansión alar y corporal por } \\
\text { presión de aire traqueal y } \\
\text { digestiva; endurecimiento y } \\
\text { melanización }\end{array}$ \\
\hline $\begin{array}{l}\text { R Prolinus } \\
\text { (hemiptero) }\end{array}$ & $\begin{array}{l}\text { y wiping); contacto de tarsos entre } \\
\text { si y con antenas (rubbing y } \\
\text { pulling); toma de aire por } \\
\text { digestivo; movimientos ascenso } \\
\text { descendentes cefálicos; } \\
\text { locomoción, presión abdominal }\end{array}$ & $\begin{array}{l}\text { Sujeción tarsal al sustrato; } \\
\text { contracciones peristálticas; } \\
\text { presión abdominal } \\
\text { emergencia tórax, alas y patas }\end{array}$ & $\begin{array}{l}\text { Sujeción tarsal al sustrato; } \\
\text { expansión alar y corporal por } \\
\text { presión de aire traqueal y } \\
\text { digestiva; endurecimiento y } \\
\text { melanización }\end{array}$ \\
\hline
\end{tabular}

Figura 2.4: Esquema del proceso de ecdisis de un insecto de tipo holometábolo y uno hemimetábolo, y el comportamiento asociado a cada etapa. Las flechas indican los procesos que marcan la finalización de cada etapa. Nótese el detalle en gris donde se compara el comportamiento de sujeción al sustrato mediante uso de los tarsos y en qué etapa se da en cada especie. Además en subrayado se detalla y compara el comportamiento de ingesta de aire por la probóscide y en qué etapa se da en cada especie.

La regulación endócrina del proceso de ecdisis es compleja, e incluye un número elevado de factores hormonales (Fig. 2.5). Los neuropéptidos centrales en la regulación de la muda y cuya función se encuentra más conservada entre distintos grupos de artrópodos son: ETH; EH; CCAP y BUR (Fig. 2.5). Además, en algunos insectos como M. sexta (lepidóptero) y Bractocera dorsalis (díptero), se incluye la hormona $\mathrm{CZ}$ como un factor central regulador de la muda (Zitnan, Kim et al. 2007; Hou, Jiang et al. 2017). 
De acuerdo a nuestros resultados en el presente trabajo, podemos afirmar además, que para el hemíptero $R$. prolixus, la hormona $\mathrm{CZ}$ también es un factor central en la regulación del ciclo de muda (ver resultados).

El primer investigador en observar un control humoral de la muda fue Stefan Kopec entre los años 1917-1922 (Marchal 2010). en sus trabajos de extracción de cerebro en el lepidóptero Porthetria dispar. Kopec, con sus trabajos demostró que inyecciones de una un compuesto (extraído a partir del cerebro) a la que denominó "Hormona de la Eclosión" (EH, del inglés eclosion hormone) activaban el proceso de muda en insectos adultos en estado de latencia (Truman 1992). Estas observaciones posteriormente fueron confirmadas en el gusano de seda B. mori (Truman and Riddiford 1970). Trabajos subsiguientes en lepidópteros como M. sexta y Antheraea pernyi detectaron la expresión de EH en células neurosecretoras del cerebro denominadas neuronas ipsilaterales (Ias) tipos 1 y 2 . Estudios posteriores en los lepidópteros $M$. sexta y $B$. mori demostraron realmente que la EH se sintetiza y libera a partir de las células ventromediales ubicadas en la región sagital posterior del cerebro, mientras que las células ipsilaterales tipo 1 y 2 (ubicadas en la región anterior del cerebro), expresan el neuropéptido corazonina ( $\mathrm{CZ}$; del inglés corazonin) y péptido transportador de iones (ITP; del inglés ion transporting peptide) respectivamente (Truman and Reiss 1988; Kono, Nagasawa et al. 1990). Posteriormente se demostró que el papel principal de EH es regular la expresión y liberación de ETH (Gammie and Truman 1999).

En las especies donde mejor se ha estudiado la regulación de la ecdisis mediada por neuropéptidos (D. melanogaster, M. sexta y B. mori), ETH resultó el regulador central de una red endócrina que finaliza con la post-ecdisis (Fig. 2.5). La hormona ETH fue detectada por primera vez, como un compuesto asociado a la ecdisis, liberado a partir de glándulas epitraqueales del gusano de seda B. mori (Kimon 1913). Casi 80 años después, estas glándulas fueron estudiadas nuevamente en el insecto lepidóptero Galleria mellonella, debido a su inmunoreactividad frente a un suero desarrollado para péptidos de la familia FMRF-amida (Zitnan 1989). Subsiguientes estudios en B. mori y M. sexta permitieron la completa caracterización funcional y estructural de las glándulas epitraqueales, las cuales están compuestas de células endócrinas denominadas Inka (Akai 1971; Zitnan, Kingan et al. 1996). Aunque existe una gran variación entre el número, disposición, forma, tamaño y ubicación de las células Inka en el sistema traqueal, éstas se han observado en todos los órdenes de artrópodos, y en todos los casos 
asociadas a la secreción de ETH (Zitnan, Hollar et al. 2002; Zitnan, Zitnanova et al. 2003).

Si bien ETH se ha detectado en los genomas de todas las especies de insectos secuenciados hasta el momento, los análisis funcionales se han centrado principalmente en holometábolos (Kim, Zitnan et al. 2006; Zitnan, Kim et al. 2007; Arakane, Li et al. 2008). En muchos insectos, como T. castaneum, D. melanogaster, N. lugens o las langostas Schistocerca americana y L. migratoria, el prepropeptido codificado por el gen ETH da origen a dos isoformas (ETH 1 y 2) (Roller, Zitnanova et al. 2010). En otros casos como Acyrthosiphon pisum, A. mellifera, Nasonia vitripenni y R. prolixus, ETH poseen una única isoforma (Roller, Zitnanova et al. 2010; Ons, Sterkel et al. 2011). Por otro lado, en B. mori y M. sexta, el precursor de ETH codifica además la hormona desencadenante de la pre-ecdisis (PETH) (Zitnan, Hollar et al. 2002). Por último, en los lepidópteros antes mencionados, y los dípteros D. melanogaster y Anopheles gambiae, este mismo gen también codifica el péptido asociado a ETH (APETH) (Roller, Zitnanova et al. 2010). Estas hormonas son sintetizados y secretadas en forma aislada o conjunta, en forma variables de acuerdo a cada especie de insecto (Zitnan, Ross et al. 1999).

A pesar de su importancia en la fisiología y regulación de la ecdisis en holometábolos, existe un único estudio funcional de ETH en hemimetábolos. Se trata de un trabajo publicado recientemente que utilizó como modelo la langosta $S$. gregaria (Lenaerts, Cools et al. 2017). En este estudio se identificó el precursor y el receptor para ETH (SchgrETHpre y SchgrETHR respectivamente). Se determinó que SchgrETHpre produce dos péptidos maduros (ETH 1 y ETH 2), lo cual confirmó resultados previamente observados por espectrometría de masas en otras dos especies de langosta, L. migratoria y S. americana (Clynen, Huybrechts et al. 2006; Roller, Zitnanova et al. 2010). Además, mediante un ensayo de bioluminiscencia se determinó (tanto para ETH 1 como para ETH 2) que SchgrETHR activa dos vías de respuesta a través de los segundos mensajeros $\mathrm{Ca}^{+2}$ y AMPc (Lenaerts, Cools et al. 2017). Finalmente se determinó el patrón de expresión de SchgrETHpre y SchgrETHR por qRT-PCR. En ambos casos el mayor nivel de expresión se observó en tráquea, aproximadamente seis veces superior a otros tejidos. Los demás tejidos donde se detectó expresión de transcripto, tanto de SchgrETHpre como SchgrETHR, fueron cerebro y lóbulos ópticos, complejo CA $+\mathrm{CC}$, epidermis, cuerpo graso, túbulos de Malpighi, glándulas 
protoráxicas y gónadas de hembra y macho (Lenaerts, Cools et al. 2017). Por otro lado, se realizó el silenciamiento transcripcional (en ninfas de $5^{\text {to }}$ estadio), tanto de SchgrETHpre (dsETH) como de SchgrETHR (dsETHR), utilizando la técnica de RNAi. En ambos casos se observó un arresto de muda al momento de la ecdisis, con valores de $88 \%$ y $100 \%$ de arresto de muda para dsETH y dsETHR respectivamente. Sin embargo, en ninfas de $4^{\text {to }}$ estadio este resultado solo se observó para dsETH. Finalmente, para evaluar la relación existente entre ecdisteroides y ETH, previamente observada en insectos holometábolos (Zitnan, Kim et al. 2007), se silenció el receptor de ecdisteroides $S c h g r E c R / S c h g r R X R$ en ninfas recién emergidas del último estadio preadulto. En estos insectos se observó una disminución significativa tanto para SchgrETHpre como para SchgrETHR respectivamente (respecto de insectos controles inyectados con solución ringer) (Lenaerts, Cools et al. 2017). Este trabajo sugiere finalmente, que la ecdisona pudiese estar implicada en la regulación de la transcripción del gen ETH en hemimetábolos en general, al igual que lo observado en holometábolos.

En algunas especies de insectos, el neuropéptido $\mathrm{CZ}$ inicia la cascada de ecdisis a través de estimular la síntesis de ETH. Sin embargo, este papel no fue confirmado para D. melanogaster (Lee, Kim et al. 2008). Además, el sistema peptidérgico de CZ (neuropéptido y receptor) parecen estar ausentes de los genomas de los coleópteros (Predel, Neupert et al. 2007; Li, Predel et al. 2008). Sin embargo, en un estudio realizado en el díptero tefrítido $B$. dorsalis, donde se silenció el receptor de $\mathrm{CZ}$ $(B d C r z R)$, se observó un retardo en los tiempos de transición larva-pupa y de pupación. Se observó además una disminución significativa por simple inyección de $\mathrm{CZ}$ sintética en la expresión de ETH. Por último, insectos ligados en la región cefálica (para evitar el flujo de péptidos cerebrales), fueron rescatados por inyección parenteral de péptido sintético de $\mathrm{CZ}$ por un lado y ETH por otro. En ambos casos, el rescate del proceso de pupación fue exitoso, y se observaron diferencias significativas en el porcentaje de insectos que alcanzaron el estadio de pupa (respecto a insectos inyectados con buffer fosfato). Estos experimentos confirmaron el papel regulatorio de la $\mathrm{CZ}$ del ciclo de muda en un insecto no lepidóptero (Hou, Jiang et al. 2017).

Otro neuropéptido central en la regulación de la ecdisis es el péptido llamado CCAP (del inglés cardioactive crustacean peptide). Esta hormona, en combinación con los péptidos MIPs (Ast-B), regula la frecuencia e intensidad de las contracciones de la musculatura esquelética y visceral de distintos sistemas de órganos, lo cual permite al 
insecto iniciar y terminar exitosamente la ecdisis (Resh 2009; Gilbert 2012). El neuropéptido CCAP fue originalmente identificado en el crustáceo Carcinus maenas (Stangier, Hilbich et al. 1987), y caracterizado poco tiempo después en especies de insectos como M. sexta, Spodoptera eridania, y Tenebrio molitor (Cheung, Loi et al. 1992; Furuya, Liao et al. 1993; Lehman, Murgiuc et al. 1993).

Se observó en el SNC de todos los insectos testeados por inmuno-marcación: en células neurosecretoras dorsales y ventrales del cerebro; en los lóbulos ópticos; y en neuronas bilateralmente pareadas de los ganglios SOG, torácicos y abdominales (o ganglios resultantes de la fusión de los mismos) (Lee and Lange 2011; Gilbert 2012).

Además se ha observado marcación en tejidos periféricos: 1) intestino medio anterior y medio posterior de insectos hemimetábolos como L. migratoria, $P$. americana, Baculum extradentatum y R. prolixus (Donini, Ngo et al. 2002; Sakai, Satake et al. 2004; Lange and Patel 2005; Lee and Lange 2011; Matsui, Sakai et al. 2013); 2) aorta anterior y músculos alares asociados a la aorta de $B$. extradentatum y $M$. sexta (Davis, Dulcis et al. 2001; Lange and Patel 2005; Ejaz and Lange 2008); 3) glándulas salivales, túbulos de Malpighi y procesos asociados al aparato reproductor masculino de $R$. prolixus (Lee and Lange 2011); 4) en oviducto y espermateca de $R$. prolixus y L. migratoria (Donini and Lange 2002; da Silva and Lange 2006; Lee and Lange 2011). Por fuera del SNC la inmuno marcación se observa como proyecciones nerviosas de neuronas presentes en los ganglios torácicos y abdominales. Sólo en el intestino medio de B. extradentatum ("bicho palo") y la cucaracha $P$. americana se observaron células neurosecretoras de CCAP, dispuestas en forma dispersa (Sakai, Satake et al. 2004; Lange and Patel 2005; Sakai, Satake et al. 2006; Matsui, Sakai et al. 2013). Por otro lado en L. migratoria se observó marcación de procesos axonales, pero no cuerpos neuronales (Donini, Ngo et al. 2002).

Se considera que las células nerviosas pertenecientes a la red neuronal 27/704 que expresan CCAP, están principalmente relacionadas con la regulación de la ecdisis. Esta red controla la contracción rítmica de la musculatura esquelética abdominal durante la ecdisis y está integrada por la neuronas 27 e interneuronas 704 (Gilbert 2012). Las primeras deben su nombre a que fueron identificadas en los ganglios 2-7 de estadios larvales tempranos de $M$. sexta, donde se disponen bilateralmente pareadas, de un par por ganglio. Además, en cada ganglio de ubica en la misma posición que las 
células 27, un par de interneuronas 704 que presentan marcación positiva para CCAP (Davis, Dulcis et al. 2001). Debido a la fusión de ganglios torácicos y abdominales en distintos órdenes de insectos, podemos observar de 2 a 4 pares de neuronas con marcación positiva para CCAP en cada ganglio (torácico, abdominal o fusión de ambos). Estas neuronas en casi todos los casos pertenecen a la red 27/704 en insectos holometábolos, o se consideran células homologas de las mismas en insectos hemi- y ametábolos. En algunos insectos, como por ejemplo L. migratoria, se observó además un par de neuronas con intensa marcación positiva por fuera de la red 27/704, dispuestas en forma lateral, de a un par por ganglio abdominal, en los ganglios 1-7 (Schoofs, Vanden Broeck et al. 1993; Schoofs, Veelaert et al. 1996; Schoofs, Veelaert et al. 1997). En R. prolixus se observaron células homologas de la red 27/704 dentro del SNC, tanto por hibridación in situ como por inmuno marcación. En el SOG se observó un par de neuronas bilateralmente pareadas y dos pares de neuronas laterales únicas, por fuera de la red 27/704 (Lee and Lange 2011), al igual que en L. migratoria (Schoofs, Vanden Broeck et al. 1993; Schoofs, Veelaert et al. 1997). Además, se detectó un par de neuronas bilateralmente pareadas en el PTG y tres pares en el MTGM, en ambos casos homologas a neuronas de la red 27/704 (Lee and Lange 2011).

Respecto a la regulación endocrina de la síntesis de CCAP, se ha determinado en lepidópteros que un aumento en la concentración de ETH en hemolinfa desencadena un aumento en la transcripción y liberación de CCAP (Gammie and Truman 1999; Kim, Zitnan et al. 2006). Cuando ETH activa el receptor RETH-A (en ganglios torácicos y abdominales) se produce una liberación masiva de CCAP dentro y fuera del SNC, a través de los nervios torácicos y abdominales, y hacia la hemolinfa a partir de los órganos neurohemales asociados a los mismos (Zitnan, Kim et al. 2007). Por un lado, CCAP en forma aislada o en combinación con los MIPs, es capaz de regular la contracción rítmica de la musculatura esquelética abdominal lo que permite al insecto desprenderse de la vieja cutícula. Por otro, en conjunción con el péptido $\mathrm{EH}$, favorece el aumento de la contracción de la musculatura visceral del sistema digestivo, principalmente de la bomba cibarial de la probóscide, lo cual posibilita la ingesta de aire para aumentar la presión interna del insecto (Gammie and Truman 1999; Gilbert 2012). Por otra parte, CCAP facilita la correcta diseminación de todos los factores hormonales por el hemocele del insecto, dado que participa en la regulación de la tasa de contracción de la aorta. Por otro lado además, favorece la correcta reabsorción de 
líquidos durante el final de la pre-ecdisis, dado que afecta la contracción de la musculatura visceral de los túbulos de Malpighi e intestino (Gilbert 2012).

Existen trabajos que reportan datos indirectos acerca del potencial de CCAP como factor regulador de la ecdisis en hemimetábolos tales como las langostas $S$. gregaria y L. migratoria, (Schoofs, Veelaert et al. 1997; Zilberstein, Ewer et al. 2006). En el caso de $S$. gregaria se observó un incremento en el GMPc en forma previa al proceso de ecdisis en neuronas que sintetizan y liberan CCAP (Ewer and Truman 1996). Por otro lado, en L. migratoria se comprobó que la aplicación de CCAP aumenta la actividad de las motoneuronas que integran el ganglio frontal, las cuales inervan la musculatura de la bomba cibarial, que participa en el comportamiento de ingesta de aire durante la ecdisis (Zilberstein, Ewer et al. 2006). Sin embargo, donde se vinculó con mayor claridad a CCAP con el proceso de ecdisis de hemimetábolos fue en un estudio realizado en $R$. prolixus (Lee, Orchard et al. 2013). El precursor de CCAP en este insecto produce por clivaje proteolítico un único péptido maduro con la secuencia PFCNAFGCTa altamente conservada evolutivamente (Lee and Lange 2011). Por otro lado, RhoprCCAPR es un receptor acoplado a proteína $\mathrm{G}$ representado por una única isoforma, a diferencia de otros insectos como A. gambiae, B. mori y T. castaneum donde existen dos variantes de splicing (Lee, Vanden Broeck et al. 2013). Al igual que para RhoprCCAPpre, RhoprCCAPR posee una elevada conservación de secuencia con otros insectos, principalmente con himenópteros como Apis florea, A. mellifera, Bombyx impatiens, Megachile rotundata, Nasonia vitripennis, de acuerdo al análisis filogenético (Lee, Vanden Broeck et al. 2013).

El tejido donde se observó mayor expresión de RhoprCCAPR fue el intestino medio posterior, seguido por el SNC y el aparato reproductor de la hembra (Lee, Vanden Broeck et al. 2013). Además se determinó el patrón de expresión temporal durante el ciclo de muda (entre ninfa $4^{\text {ta }}$ y $5^{\text {ta }}$ ); el punto máximo de expresión se alcanzó tres días antes de la ecdisis (Lee, Vanden Broeck et al. 2013). Finalmente se expresó RhoprCCAPR en un sistema heterólogo utilizando células de ovario de hámster CHOWTA11, para realizar un ensayo de bioluminiscencia. Por medio de esta técnica se confirmó la interacción funcional específica entre RhoprCCAPpre y RhoprCCAPR (Lee, Vanden Broeck et al. 2013). 
El silenciamiento de los genes RhoprCCAP (dsCCAPR) y RhoprCCAPR (dsCCAPR) por separado y en forma conjunta (dsCCAP + dsCCAPR) reveló un claro efecto de RhoprCCAP en la regulación del proceso de ecdisis. En los insectos tratados se registraron cuatro fenotipos diferentes: ecdisis normal (entre día 9-14 post alimentación de sangre (PBM); mortalidad al momento de la ecdisis (entre día 9-14 PBM); ecdisis tardía (posterior a día 15 PBM); mortalidad tardía (posterior a día 15 PBM). Dentro de los grupos control, no inyectados o inyectados (días 2 y 4 post ecdisis del estadio previo) con un gen inespecífico, el porcentaje de insectos que completaron la ecdisis normalmente fue de 97,4\% y 82,6\% respectivamente. En los insectos tratados se observó un arresto de muda de aproximadamente el $51 \%$ para dsCCAP ( $\approx 4 \%$ fue mortalidad tardía), $66 \%$ para dsCCAPR $(\approx 10 \%$ fue mortalidad tardía $), \quad \mathrm{y}$ aproximadamente el $85 \%$ para dsCCAP + dsCCAP $(\approx 13 \%$ fue mortalidad tardía $)$. Además, para el grupo dsCCAP se observó el fenotipo de retraso de muda en un $12 \%$ de los insectos tratados y 3\% para dsCCAPR. No se observó este fenotipo cuando se inyecto dsCCAP+dsCCAP (Lee, Orchard et al. 2013). En conjunto, estos resultados sugieren que la hormona CCAP posee un papel central regulador de la ecdisis también en insectos hemimetábolos (Lee, Orchard et al. 2013).

El bursicon (BUR) es otra hormona proteica importante en la regulación de la muda. Presenta un papel fundamental tanto en la iniciación como en la finalización de la ecdisis (Cottrell 1962; Cottrell 1962; Cottrell 1962; Fraenkel and Hsiao 1962; Vincent 1972; Dai, Dewey et al. 2008; Li, Predel et al. 2008). Fue descubierto originalmente en la mosca Calliphora erythrocephala, e identificado como una hormona que regulaba el oscurecimiento de la cutícula (Cottrell 1962; Cottrell 1962; Cottrell 1962; Fraenkel and Hsiao 1962). Sin embargo, fue purificado y caracterizado 40 años después en $D$. melanogaster (Dewey, McNabb et al. 2004). El BUR es un heterodímero constituido por dos subunidades, denominadas bur y pbur, o también $\alpha$ y $\beta$. Estas unidades consisten en dos péptidos con un sitio conservado de cisteínas que permiten la unión entre ambas (Luo, Dewey et al. 2005; Mendive, Van Loy et al. 2005).

Respecto del patrón de expresión del BUR (ambas subunidades), se observó en los insectos $M$. sexta, $D$ melanogaster y $P$. americana que es coincidente con neuronas bilateralmente pareadas que expresan a su vez el péptido CCAP, pertenecientes a la red 27/704, ubicadas en los ganglios SOG, torácicos y abdominales (o fusión de los mismos) (Honegger, Market et al. 2002; Kim, Zitnan et al. 2006; Dai, Dewey et al. 
2008). Éstas neuronas, se disponen en un número variable de pares por ganglio, de acuerdo al grado de fusión entre ganglios por especie (Kim, Zitnan et al. 2006).

Respecto a su función, participa en la plasticización inicial de la cutícula, así como en la expansión, esclerotización y melanización que ocurren durante la postecdisis (Honegger, Market et al. 2002; Kim, Zitnan et al. 2006; Dai, Dewey et al. 2008). Además, en D. melanogaster se observó que interviene en la regulación de la extensión alar (Baker and Truman 2002). Si bien su patrón de expresión y características funcionales han sido confirmados en distintos insectos (Honegger, Dewey et al. 2008), el mecanismo por el cual este péptido produce dos fenómenos absolutamente contrapuestos sobre la cutícula permanece todavía sin comprenderse en profundidad.

Respecto a estudios realizados en insectos hemimetábolos, se observó inmunomarcacion para el BUR en los insectos P. americana, Gryllus bimaculatus, Teleogryllus commodus, L. migratoria (Kostron, Kaltenhauser et al. 1996; Kostron, Market et al. 1999; Honegger, Market et al. 2002; Luo, Dewey et al. 2005). Trabajando en estos insectos, Hans-Willi Honegger y su grupo (2002, 2004) descubrieron secuencias parciales del BUR, y propusieron que debía tratarse de un homo- o heterodímero. Estos resultados permitieron además, determinar la masa del BUR de alrededor de $30 \mathrm{kDa}$, y sentaron las bases para la posterior determinación de la estructura molecular en D. melanogaster (Dewey, McNabb et al. 2004). Por otro lado, en todos los insectos hemimetábolos testeados se observó marcación en neuronas bilateralmente pareadas del segundo ganglio abdominal, a excepción de Gryllus bimaculatus donde se observó marcación en los ganglios torácicos 1 y 2 (Kostron, Kaltenhauser et al. 1996). Con respecto al patrón de expresión temporal, en $P$. americana y $G$. bimaculatus se observó que el BUR permanecía a altas concentraciones después de la ecdisis, sin embargo en L. migratoria decrecía al finalizar la post ecdisis, lo cual fue atribuido a que este insecto continúa su crecimiento tisular post ecdisis (Kostron, Marquardt et al. 1995). Por otro lado, se observó en $P$. americana y $T$. commodus que el máximo nivel de expresión de las subunidades bur y pbur se producía en forma inmediatamente previa a la ecdisis (Luo, Dewey et al. 2005).

En $R$. prolixus no se detectó la liberación de BUR desde el SNC al hemocele inmediatamente antes de la ecdisis (Orchard and Steel 1980). Sin embargo, en un estudio realizado sobre M. sexta (Dai, Dewey et al. 2008), se indica la incapacidad de 
detectar el BUR en el SOG 1-2 días pre-ecdisis, e hipotetiza que se debe a la incapacidad del anticuerpo para penetrar la gruesa cubierta del SNC en esta etapa del desarrollo. Debido a estos antecedentes y fundamentalmente la ausencia de información en insectos no holometábolos, se asume la necesidad del estudio en profundidad de este péptido en $R$. prolixus, tanto como en insectos hemimetábolos en general.

Existen además, otros factores hormonales asociados a la ecdisis, los cuales regulan procesos como la reabsorción de líquidos y contracción de distintos grupos musculares en diferentes etapas del proceso. Por ejemplo, en M. sexta, la hormona kinina en coexpresión con las hormona diuréticas 30 y 41 regulan comportamientos de contracción muscular durante la pre-ecdisis (Kim, Zitnan et al. 2006). Por otro lado, kinina y DH en combinación con ITP, CRF-símil DHs, y calcitonina-símil DH31, participan en el balance hídrico y de iones en la hemolinfa durante la pre-ecdisis (Phillips and Dockrill 1968; Balshin and Phillips 1971; Meredith, Ring et al. 1996; Kim, Zitnan et al. 2006).

Por su parte, los péptidos MIPs (o Ast-B), FGL-amida, FR-amida y los péptidos SNPF activan una red neuronal inhibitoria que retarda las contracciones musculares de la pre-ecdisis. A su vez, los MIPs son coexpresados en conjunto con CCAP durante la ecdisis, lo cual provoca el patrón característico de contracciones rítmicas de esta etapa. Dicho patrón no se logra correctamente si ambos péptidos no son liberados de manera conjunta (Kim, Zitnan et al. 2006). Por último, se observó que el neuropéptido activador de la biosíntesis de feromonas (PBAN, del inglés, pheromone biosysntesis activating neuropeptide), JH y la hormona de melanización y enrojecimiento ( $\mathrm{MRCH}$, del inglés melanization and reddish coloration hormone) participan en la melanización de la cutícula en larvas de los lepidópteros M. sexta y Mamestra brasicae (Hiruma 1980; Hiruma and Riddiford 1984). Se determinó además, que en M. brasicae, Leucania separata, y S. litottalis, la melanización de la cutícula está bajo el control hormonal de MRCH (Matsumoto, Kitamura et al. 1990), mientras que la síntesis de ommocromos (pigmentos visuales sintetizados a partir del triptófano) es regulada tanto por $\mathrm{MRCH}$ como por JH (Hiruma and Riddiford 1984). Por otro lado, se observó en estadios tempranos de B. mori y M. sexta que la baja concentración de JH genera la deposición de gránulos de pre-melanina y fuerte melanización (Akai, Kiguchi et al. 1971; T. Curtis, Hori et al. 1984). Sin embargo, MRCH no regula el proceso de melanización en estos lepidópteros, el cual está bajo el control de JH en combinación con un factor endocrino 
(aún no identificado) liberado a partir de los ganglios abdominales (Hiruma 1980; Hiruma and Riddiford 1988).

En la figura 2.5 se presenta un resumen gráfico de la red de regulación neuropeptídica de los distintos momentos de la ecdisis detallado más arriba. Cabe destacar que estos modelos han sido propuestos en base a resultados obtenidos en insectos holometábolos (principalmente D. melanogaster, M. sexta y B. mori, sobre los cuales ha sido estudiado en mayor profundidad este proceso) y que aún está pendiente una caracterización de la red peptidérgica de regulación de la ecdisis en hemimetábola. Con ese objetivo abordamos los experimentos cuyos resultados se detallan a continuación.

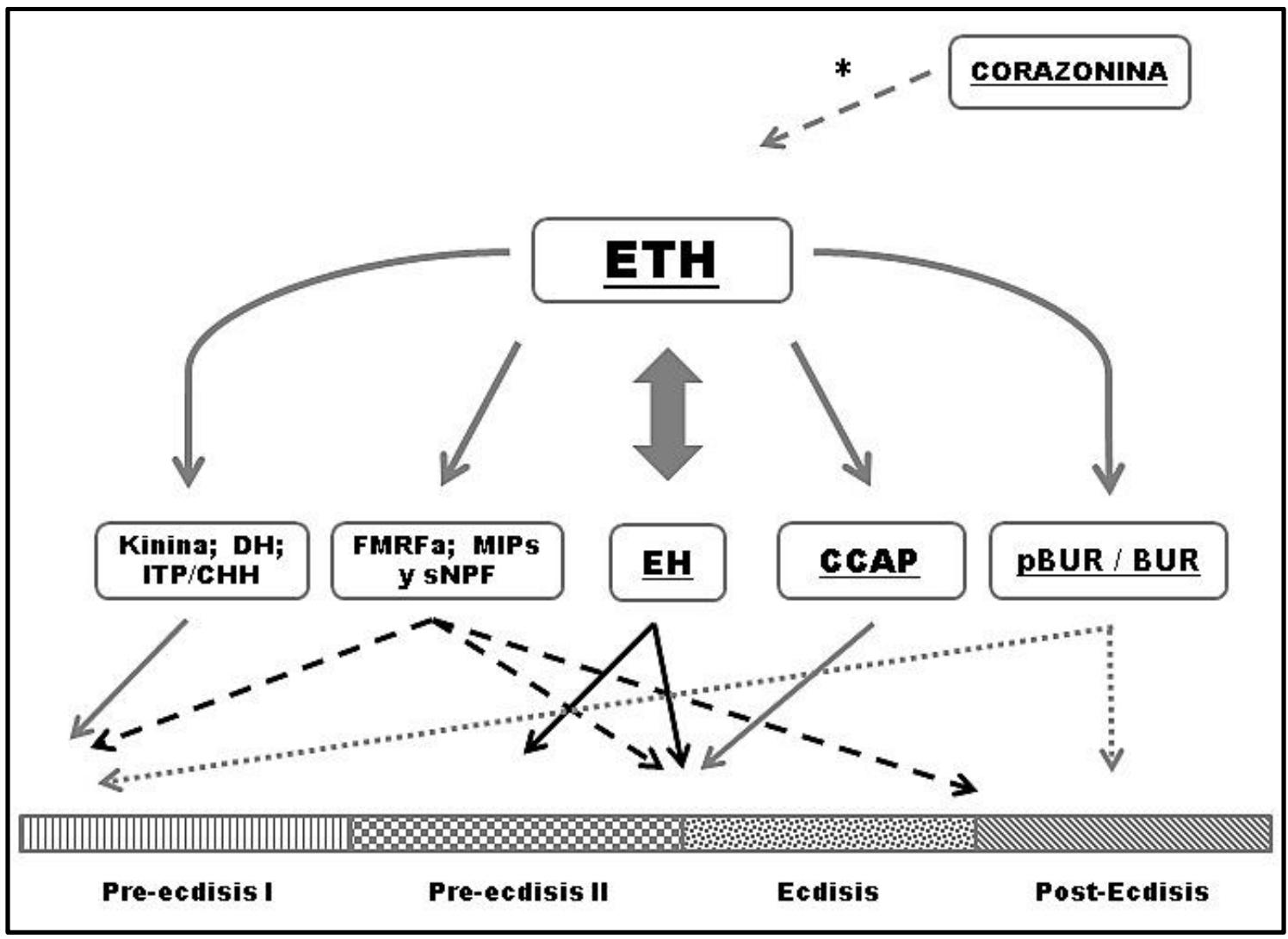

Figura 2.5: Esquema del proceso de ecdisis de un insecto y la regulación endocrina asociada al mismo. Modelo consenso propuesto para los insectos holometábolos M. sexta, T. castaneum y D. melanogaster. ETH: hormona de la ecdisis; DH: hormona diurética; ITP/CHH: péptidos símiles al péptido transportador de iones; FMRFas: péptidos de la familia FMRF-amida; MIPs: allatostatina B; sNPF: péptido F corto; EH: hormona de la eclosión; CCAP: péptido cardio-acelerador de los crustáceos; pBUR: péptido coexpresado con el bursicon; BUR: bursicon. El $(*)$ indica que esta vía ha sido observada únicamente en el lepidóptero $M$. sexta y díptero $B$. dorsalis. Los péptidos centrales en la regulación de la ecdisis se encuentran subrayados. 


\subsubsection{Silenciamiento transcripcional mediante uso de dsRNA.}

El ARN interferencia es una técnica que consiste en la supresión de la expresión de un gen determinado de manera específica (Scott, Michel et al. 2013). El primer antecedente que dio origen a esta técnica fue la introducción de un gen extra para el color purpura (antocianina) en petunias, lo cual producía el silenciamiento de ambas copias (Jorgensen 1990). En el mismo sentido, se reportaron observaciones en el hongo Neurospora crassa, donde copias extra de un gen producían la pérdida del color naranja (Romano and Macino 1992). Finalmente, en un trabajo sobre silenciamiento de genes de desarrollo en Caenorabditis elegans se observó que el ARN doble hebra producía un mayor efecto de silenciamiento que el ARN simple hebra, sea este sentido o anti sentido (Guo and Kemphues 1995). Sin embargo, en ninguno de los trabajos mencionados se logró explicar el proceso por el cual se producía el silenciamiento transcripcional.

El mecanismo de acción del ARN interferencia fue descubierto y perfeccionado en los trabajos realizados sobre C. elegans por los científicos Andrew Fire y Craig Mello, lo cual les valió el premio nobel de fisiología y medicina en el año 2006 (Fire 2007). Los autores silenciaron el gen $u n c-22$, que codifica para un proteína que participa en la estabilidad del miofilamento, mediante tres aproximaciones diferentes. Se inyecto ARN simple hebra (sentido y antisentido) y doble hebra (ARNdc) a distintas concentraciones y se observó el comportamiento en cinco periodos de tiempo (0-6hs; 615s; 15-27hs; 27-41hs; 41-56hs). El ARN simple hebra sentido (+ARNsc) se inyectó en un concentración de 3600000 moléculas por gónada. El ARN antisentido (-ARNsc) ese inyecto a la misma concentración, y una dilución a la mitad. Por último el ARNdc se inyecto a cinco concentraciones: 30, 70, 200 y 600 (mil) y 1200000 (Fire, Xu et al. 1998).

Se demostró que el dsRNA interacciona por complementariedad de bases con el mARN nativo de la célula. El efecto del dsRNA (a la mitad de concentración), es aproximadamente 100 veces mayor que para el ARN simple hebra (sentido o antisentido), el cual además pierde su efecto aproximadamente $24 \mathrm{hs}$ después de la aplicación (Fire, Xu et al. 1998; Montgomery and Fire 1998; Fire 1999; Fire 2007). En la actualidad se han descripto tres tipos principales de RNAi, el micro ARN (miRNA), el ARN asociado a proteínas Piwi (piRNA) y el ARN interferente pequeño (siRNA), 
que es el que se utiliza habitualmente en estudios de silenciamiento transcripcional en insectos (Burand and Hunter 2013; Scott, Michel et al. 2013).

Los miRNA se encuentran codificados en el genoma y constituyen factores de regulación traduccional. Han sido descriptos en numerosos organismos eucariotas de distintos reinos (Meister and Tuschl 2004; Shabalina and Koonin 2008; Berezikov 2011) e incluso en virus (Cullen 2011; Cullen 2011). Por otro lado, se han observado secuencias conservadas de miRNA que participan en la formación de la capside proteica de distintos tipos de virus de insectos como vaculovirus, ascovirus, nudivirus, etc. (Cullen 2011; Cullen 2011). A lo largo de la evolución se han insertado en el genoma de insectos a través de sucesivos procesos infecciosos virales (no letales) (Singh, Levitt et al. 2010). Se ha demostrado que participan en la respuesta inmunológica innata de los insectos contra las infecciones virales (Kingsolver, Huang et al. 2013) (Figura 2.6).

Los piRNA también se encuentran codificados en el genoma, pero poseen un modo de procesamiento diferente, y menos estudiado que el de los miRNA, en el cual no participan las proteínas Drosha y Dicer. Drosha es una ribonucleasa nuclear que corta fragmentos de tamaño medio de ARN, aproximadamente de 100pb. Dicer por otro lado, es una ribonucleasa citoplasmática de la familia de ARNasas III, que corta grandes fragmentos de ARN doble hebra en fragmentos menores de aproximadamente $22-25 \mathrm{pb}$, dejando dos bases libres en cada extremo (Shabalina and Koonin 2008; Ketting 2011) (Fig. 2.6). Los piRNA se encuentran codificados como un largo precursor de ARN de cadena simple, que no posee secuencias vecinas para formar horquillas, como sucede con los miRNA. Este tipo de ARN se encuentra asociado fundamentalmente al silenciamiento de transposones. Las proteínas Piwi forman parte de la misma familia que las proteínas argonauta por poseer el domino conservado PIWI. Las proteínas argonautas se han descripto en organismos tan diversos, como Homo sapiens, D. melanogaster y Arabidopsos thaliana (Meister and Tuschl 2004). Poseen dos dominios característicos: PIWI que participa en la interacción con Dicer, y el dominio PAS (del inglés piwi argonaute swille) el cual es un dominio de unión a ARN doble hebra. Son proteínas de unión a ARN fundamentalmente, pero dado el alto grado de homología entre el dominio PIWI y proteínas de la familia ARNasa H por un lado, y el dominio PAZ y proteínas Dicer de la familia ARNasa III por otro, se plantea la posibilidad de que también posean actividad nucleasa (Meister and Tuschl 2004). Por último, las 
proteínas Piwi se ha observado que se expresan fundamentalmente en gónadas de $D$. melanogaster (Meister and Tuschl 2004; Burand and Hunter 2013).

El siRNA por su parte, es un ARN de doble hebra diseñado para silenciar un gen específico. Es sintetizado a partir de ADNc, mediante una ARN polimerasa (generalmente T7 o T4). Una vez que se aplica el siRNA el efecto es replicado por la célula. El procesamiento de los ARNdc se produce en el citoplasma. Sin embargo, en el caso particular del miRNA, este es procesado primariamente en el núcleo, donde es transcripto a partir del genoma por ARN polimerasas tipo 2 o 3, variable según la especie. Posteriormente a la transcripción se produce la formación de horquillas debido a la presencia de secuencias vecinas parcialmente apareables. En el paso siguiente un complejo integrado por una proteína de unión a ARN la cual varía por especie, y la ribonucleasa Drosha, se corta el transcripto en horquillas de aproximadamente $70 \mathrm{pb}$. Finalmente esta horquilla es exportada al citoplasma por un proteína llamada Exportina 5, y le es escindida la región en forma de loop o ciclo por una exonucleasa (Fig. 2.6) (Meister and Tuschl 2004; Burand and Hunter 2013).

Una vez en el citoplasma, tanto miRNA como siRNA poseen un procesamiento similar. En ambos casos se unen a una proteína denominada TRBP, la cual forma un complejo con la ribonucleasa Dicer. Este complejo corta la secuencia de ARN doble hebra en fragmentos de menor tamaño (aproximadamente 22pb para los miRNA y entre 19-21pb para siRNA), dejando dos bases libres en el extremo 3' y 5'. Posteriormente actúa una helicasa que separa ambas hebras, la hebra sentido es degradada por ribonucleasas citoplasmáticas de la familia ARNasa $\mathrm{H}$, y de esta forma se libera la ribonucleasa Dicer del complejo (Meister and Tuschl 2004; Burand and Hunter 2013).

Finalmente se unen al complejo integrado por TRBP otras enzimas, proteínas argonautas y ribonucleasas, dando origen a un complejo llamado RISC, el cual induce el silenciamiento de ARN. El miRNA puede ser procesado de dos formas, dentro de un complejo mayor de procesamiento traduccional o $p$-body que puede abarcar incluso a más de un complejo RISC, o directamente libre en el citoplasma. La primera es la forma más habitual y de acuerdo al grado de complementariedad se inhibe la traducción del transcripto o este es degradado completamente. La segunda, es la misma forma en que se procesa el siRNA, donde el complejo RISC se une a un transcripto libre en el citoplasma y lo corta 10bp aguas arriba del sitio de unión entre ambas secuencias, 
degradando de esta manera el mARN target (Fig. 2.6) (Meister and Tuschl 2004; Burand and Hunter 2013).

El grado de expresión de enzimas que forman parte del procesamiento del ARN en diferentes especies de insectos determina el grado de sensibilidad de cada insecto a la aplicación de siRNA (Singh, Levitt et al. 2010). En lepidópteros por ejemplo, tanto por vía oral como inyectada, se observó la menor tasa de respuesta a la aplicación de RNAi. De hecho, en B. mori, se observó que la sobre expresión del gen Argonauta 2 (Ago 2), aumentaba la eficiencia del RNAi ( $\mathrm{Li}$, Zeng et al. 2015). En contraposición, en coleópteros se determinó el mayor nivel de respuesta. Este resultado se vincula por un lado, con la duplicación del gen Ago 2 en T. castaneum y los genes Ago 2 y Dicer 2 en Leptinotarsa decemlineata (Singh, Levitt et al. 2010). Por otra parte, se observó que para degradar el mismo contenido de ARNdc se necesitaba mayor volumen de hemolinfa que en otros insectos, lo cual sugiere un menor contenido de ribonucleasas en el hemocele (Singh, Levitt et al. 2010).

En cuanto al modo de aplicación de ARNdc para el silenciamiento transcripcional en insectos, existen cinco métodos principales que se describen brevemente a continuación:

a) Inyección directa dentro del hemocele: es el método más utilizado y el más eficiente en cuanto al grado de silenciamiento transcripcional que se consigue. Se ha observado alta eficiencia en insectos de diferentes órdenes como B. germanica (blatodeo), A. aegypti (díptero), S. gregaria (ortóptero), T. castaneum (coleóptero), A. pisum (homóptero), M. sexta (lepidóptero), D. melanogaster (díptero), A. mellifera (himenóptero) y R. prolixus (hemíptero) (Araujo, Santos et al. 2006; Cirimotich, Scott et al. 2009; Miller, Miyata et al. 2012; Paim, Araujo et al. 2013; Wang, Wu et al. 2013; Huang, Lattorff et al. 2014; Ons, Belles et al. 2015; Wulff, Sierra et al. 2017). Usualmente se inyecta el ARNdc en la concentración deseada directamente en el cuerpo del animal, mediante una jeringa o micro-inyector.

b) Ingestión oral: puede ser más fácil técnicamente en algunas especies, aunque la eficiencia de silenciamiento que se consigue es significativamente menor que en el caso de la inyección directa. Las concentraciones de trabajo necesarias son entre 5 y 10 veces mayores que para el método por inyección, dependiendo la especie y el gen (Scott 2013). Por ejemplo para $R$. prolixus, en un trabajo donde se silencia el gen que codifica 
la expresión de la proteína nitroforina en las glándulas salivales, la tasa de eficiencia por vía inyectable es de aproximadamente el $90 \%$ en todos los estadios. Sin embargo, sólo se alcanzó una eficiencia del $42 \%$ en ninfas de 2 estadio, siendo nulos los resultados en ninfas de estadios superiores (Araujo, Santos et al. 2006; Paim, Araujo et al. 2013).

c) Topicación sobre la cutícula: Se utiliza un solvente orgánico (usualmente acetona) para favorecer la penetración. Sin embargo, la tasa de penetración es baja debido al carácter polar de la molécula de ARNdc. Por ejemplo, en un trabajo realizado en hembras de $A$. aegypti, donde se silencia la expresión de tres isoformas de una proteína inhibidora de apoptosis celular (AaeIAP1), donde se alcanzó una tasa de mortalidad de apenas entre $5-8 \%$ cada una por separado y $14 \%$ en conjunto con acetona, y entre $7-28 \%$ cada una por separado y $5 \%$ en conjunto con siQUEST, un reactivo utilizado para transfectar cultivos celulares (Pridgeon, Zhao et al. 2008). Por otro lado, en otros trabajos realizados en $A$. aegypti vía inyectable, se observaron porcentajes variables según el gen. Por ejemplo, se logró un silenciamiento del 32\% para la proteína de la olfacción semaphorina-1 (Mysore, Flannery et al. 2013) y de un 80\% para el receptor de la netrina-1, una proteína reguladora del desarrollo embrionario (Clemons, Haugen et al. 2011).

d) Transducción: se utiliza un virus para vehiculizar el dsRNA dentro del genoma del insecto. Se utilizó por ejemplo para inmunizar al mosquito $A$. aegypti frente al virus dengue. Se inyectaron hembras con el virus de ARN Sindbis, el cual poseía un inserto de la región codificante de la pre-membrana proteica del virus del dengue (Adelman, Blair et al. 2001).

e) Transgénesis: se desarrollan cepas transgénicas que expresan una secuencia específica del gen target. Se inyecta un plásmido con la secuencia del gen durante el desarrollo embrionario del insecto, a fin de silenciarlo o sobre expresarlo. Por ejemplo, en un trabajo realizado en $A$. aegypti se utiliza este método para aumentar o silenciar la expresión de un gen de desarrollo (AaeRel1) (Bian, Shin et al. 2005).

Finalmente, el grado de eficiencia de la técnica de RNAi está relacionado con cinco factores: el nivel de expresión del gen target, la respuesta fisiológica innata de la especie, el tamaño de ARNdc suministrado, su concentración y el método de aplicación. 


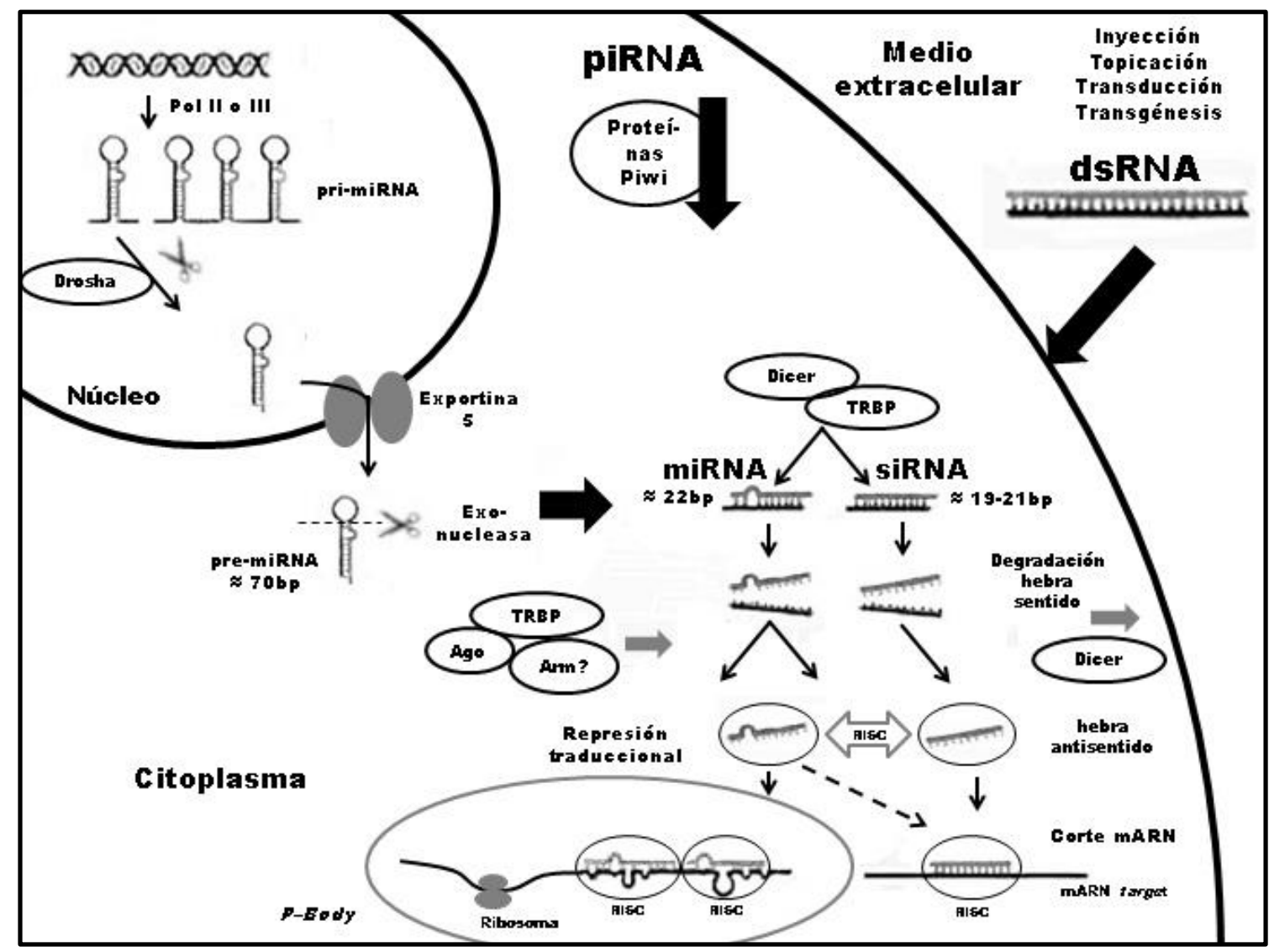

Figura 2.6: Tipos de ARN interferencia (miRNA, piRNA y siRNA) y modo de procesamiento. PrimiRNA: miRNA primario; pre-miRNA: miRNA precursor; Ago: proteína argonauta; Arm: proteína Armitage.

\subsubsection{Hipótesis}

Los neuropéptidos RhoprETH, RhoprEH, RhoprCZ y RhoprOK poseen un rol central en la regulación endócrina de la muda de $R$. prolixus.

\subsubsection{Objetivos específicos}

Caracterizar la regulación endocrina del ciclo de muda de $R$. prolixus, particularmente como se encuentran asociados a dicho proceso los neuropéptidos: orcokinina, corazonina, hormona de la eclosión y hormona desencadenante de la ecdisis. 


\subsection{MATERIALES y MÉTODOS}

\subsubsection{Insectos y disección de tejidos}

Se utilizaron ninfas de $4^{\circ}$ estadio entre los días 2 y 12 post alimentación. Para las condiciones de cría de la colonia y disección de tejidos dirigirse a Materiales y métodos Capítulo 1.

\subsubsection{Silenciamiento transcripcional mediante uso de dsRNA.}

El procedimiento se logra mediante una serie de etapas que comprenden desde la búsqueda informática de la secuencia del gen a silenciar, hasta la aplicación final del dsRNA por el medio seleccionado (en este trabajo se seleccionó la vía inyectable directo en el hemocele (Fig. 2.7).

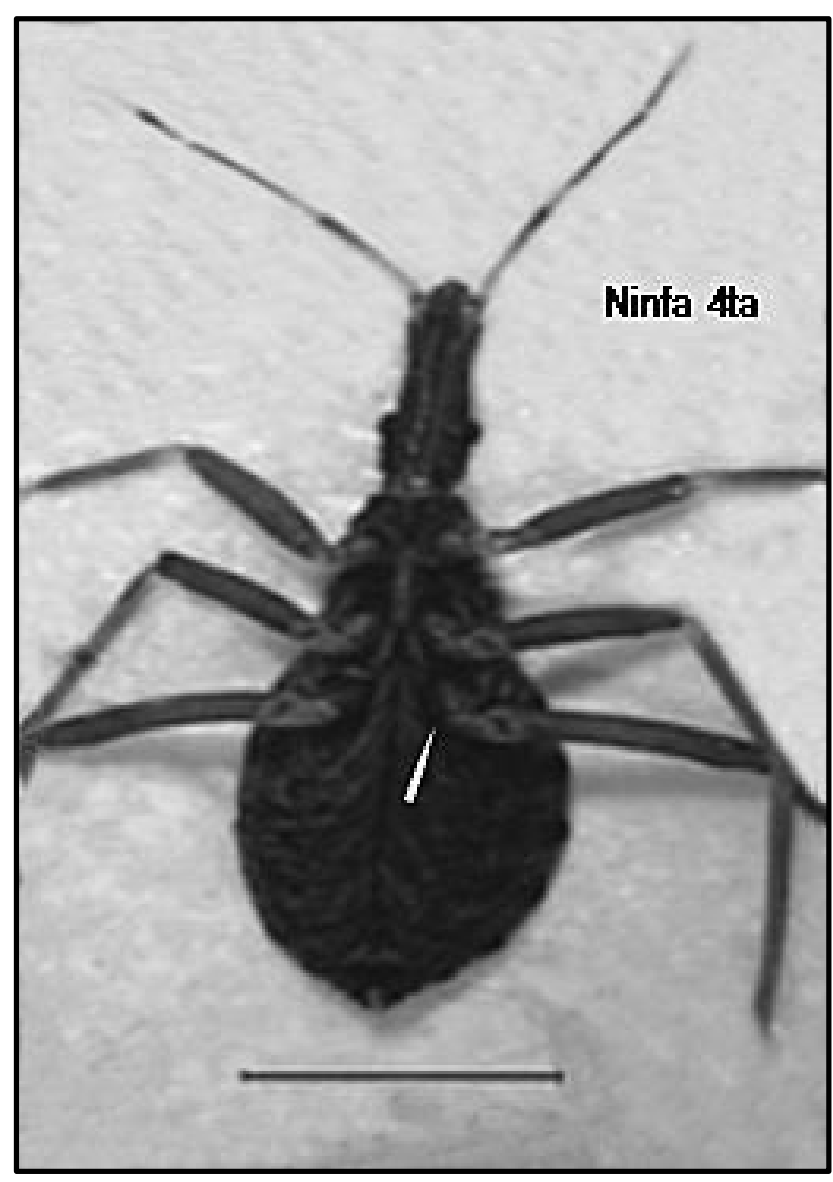


Figura 2.7: Sitio inyección de dsRNA. Se inyectaron ninfas de $4^{\text {to }}$ o $5^{\text {to }}$ estadio, introduciendo una aguja a través de membrana que une la coxa del $3^{\text {er }}$ par de patas con la cutícula del tórax (extremidad izquierda). La barra indica $2 \mathrm{~mm}$ de longitud.

\subsubsection{Búsqueda bioinformática de secuencia y diseño de primers}

Los primers ARNdc fueron diseñados para la amplificación de un fragmento de entre 250 y $350 \mathrm{pb}$ de cada gen de interés. Se tomaron como referencia las secuencias de los transcriptos RhoprOKA (número de acceso en genebank: ID: 1273300) y RhoprOKB (Numero de acceso: JF761320) (ver anexo, primers). Se diseñaron los primers con asistencia del programa online Primer3Web (http://bioinfo.ut.ee/primer3/).

Se utilizaron tres pares de primers; uno específico para el silenciamiento de RhoprOKA (flanqueando las posiciones 389-703 del transcripto); otro específico para RhoprOKB/C (posiciones 341-689) y un fragmento de 343pb para RhoprOKs (1-343). Este último fragmento está presente en las tres isoformas del gen, con lo que se utilizó para el silenciamiento conjunto (ver anexo, primers y secuencias hormonas de la muda y sitio de unión de los primers utilizados).

Respecto a los neuropéptidos relacionados con la regulación del ciclo de muda, se diseñaron primers para amplificar fragmentos de ETH (205pb); EH (208pb), CZ (212pb) y CCAP (249pb). Cada primer además posee en la región 5' una secuencia parcial del promotor de la ARN polimerasa T7 (TAATACGACTCACTATAGGG). La secuencia de todos los primers utilizados y sitio de unión de los mismos se presenta en el apartado correspondiente del anexo, detallado arriba.

Se amplificó además, un fragmento del gen de resistencia a ampicilina (ausente en el genoma de $R$. prolixus) a partir del plásmido pBluescript (ver anexo, primers), como gen control de silenciamiento inespecífico (efecto off target del ARNdc).

\subsubsection{Polimerización del dsRNA e inyección}

La polimerización del dsRNA se desarrolló siguiendo las especificaciones detalladas por el protocolo de la T7 ARN polimerasa. El producto obtenido se precipitó en etanol para su concentración y resuspendió finalmente en solución salina específica para $R$. prolixus (ver anexo, transcripción reversa de dsRNA y precipitación etanólica). 
Para determinar la concentración del dsRNA, $0,5 \mu 1 \mathrm{~s}$ de la muestra mezclados con $5 \mu \mathrm{ls}$ de formamida fueron sembrados en un gel de agarosa $1 \%$ (ver anexo, electroforesis en gel de agarosa). Se cuantificó utilizando el software de análisis de imágenes Image $2 \mathrm{X}^{\circledR}$ y un marcador de peso molecular de concentración conocida como referencia (100bp ladder; Productos Bio-Logicos ${ }^{\circledR}$, Quilmes, Argentina).

Las ninfas de $4^{\text {to }}$ estadio ( $\sin$ alimentar, 1 semana post ecdisis), fueron inyectadas bajo lupa, a través de la membrana que une la coxa del $3^{\text {er }}$ par de patas con la cutícula del tórax (Fig. 2.7). Para las inyecciones se utilizó una jeringa Hammilton ${ }^{\circledR}$ de $10 \mu 1 \mathrm{~s}$ con una micro-aguja de 33 gauges. Se suministraron $2 \mu 1 \mathrm{~s}$ de solución salina (grupo control) o dsRNA disuelto en salina $(2 \mu \mathrm{gs} / \mu \mathrm{l})$ (grupo tratado). Los insectos fueron alimentados sobre gallinas $48 \mathrm{hs}$ post-inyección. Aquellos individuos muertos dentro de los cinco días post-inyección fueron descartados del análisis por considerarse causas relativas a la inyección y manipulación. La mortalidad en estos primeros días fue homogénea en los distintos grupos experimentales, entre 1 y 2 insectos por grupo en cada ensayo.

\subsubsection{Extracción de RNA y síntesis de cDNA}

Para la toma de la muestra, el cuerpo completo del insecto se colocó en un tubo eppendorf $^{\circledR}$ de $1,5 \mathrm{~mL}$ con $500 \mu 1$ de Trizol ${ }^{\circledR}$. Todas las muestras se procesaron siguiendo las especificaciones detalladas en anexo para extracción de ARN y síntesis de ADNc.

\subsubsection{PCR cuantitativa en tiempo real}

Las muestras de ADNc obtenidas se diluyeron 1:3 en agua de calidad MilliQ. Se utilizó un equipo iQ single color en un Mini Opticon / Miniopticon Real-Time PCR Detection System (Bio-Rad $\left.{ }^{\circledR}\right)$. Los resultados fueron analizados con el software iQ5 Optical System Software v.2.0 (Bio-Rad), siguiendo el protocolo y programa detallados en el apartado anexo.

Se utilizaron como genes de referencia $\beta$-tubulina ( $\beta$-tub) y factor de elongación1 (RpEf1), que demostraron ser estables en $R$. prolixus bajo distintas condiciones (Majerowicz, Alves-Bezerra et al. 2011; Omondi, Latorre-Estivalis et al. 2015). La 
eficiencia de todos los primers utilizados en qRT-PCR fue evaluada a las concentraciones de molde: 1:2; 1:10 y 1:20 y un modelo de regresión lineal para determinarla. Se tomó como aceptable una eficiencia de entre 80 y 120\% (Pfaffl 2001; Rasmussen, Ekelund et al. 2001).

La estabilidad de los primers se determinó utilizando el programa Normfinder (Andersen, Jensen et al. 2004). La estabilidad de los genes $\beta$-tub y RpEf1, para muestras de ADNc total de ninfas $4^{\text {ta }}$ de 11 días PBM fue de aproximadamente 0,6 para cada gen. Por otro lado, a estabilidad tomando ambos genes en conjunto fue de 0,32. Debido a esto se determinó utilizar ambos genes como housekeeping, realizando un promedio de los resultados de cada uno utilizando una media geométrica (Majerowicz, Alves-Bezerra et al. 2011; Omondi, Latorre-Estivalis et al. 2015).

\subsubsection{Inyección de péptido sintético y 20-Hidroxiecdisona}

Los péptidos de secuencia NFDEIDRSGFGFN (OKA) y EFLDPLGGGHLIC (OKB) fueron sintetizados por la empresa Genscript (USA). Los péptidos fueron diluidos inicialmente a una concentración 1mM. Debido a su hidrofobicidad, OKA fue disuelto inicialmente en $20 \mu 1 \mathrm{l}$ de DMSO, y luego en agua MilliQ. OKB fue disuelto directamente en agua MilliQ. Esta solución se llevó a una concentración 0,5mM en solución salina para $R$. prolixus. Se inyectaron $2 \mu$ ls de dicha solución para obtener una concentración final estimada en hemolinfa de $100 \mu \mathrm{M}$. Las inyecciones se realizaron siguiendo el mismo procedimiento que para la inyección de dsRNA (ver arriba).

La 20-Hidroxi ecdisona (20E) (Sigma Aldrich, Alemania) fue diluida en agua MilliQ a una concentración $5 \mu \mathrm{gs} / \mu \mathrm{l}$. Se realizaron dos inyecciones los días 4 y 6 post alimentación en ninfas de $4^{\text {to }}$ estadio. Se definieron tres grupos con tres concentraciones de trabajo: diluciones $1: 10 ; 1: 5 ;$ y $1: 1$ de la dilución madre, en solución salina. Se inyectaron $2 \mu \mathrm{ls}$ de cada solución para obtener una cantidad de $1 \mu \mathrm{g}, 5 \mu \mathrm{gs} ; 10 \mu \mathrm{gs}$ totales de $20 \mathrm{E}$ para cada tratamiento. Los insectos control fueron inyectados con $2 \mu \mathrm{l}$ de solución salina. 


\subsubsection{Medición de la concentración de ecdisteroides en hemolinfa por ELISA competitivo}

Se tomaron muestras de hemolinfa $(5 \mu 1 \mathrm{~s})$ de ninfas de $4^{\text {to }}$ estadio a diferentes días post alimentación (días $2,4,6,8,10$ y 12) $(\mathrm{N}=5$ - 10 por punto).

Las muestras se procesaron y colectaron siguiendo las especificaciones del protocolo descripto por (Cuzin-Roudy, Strambi et al. 1989; Pascual, Belles et al. 1995) (ver anexo, protocolo ELISA competitivo).

\subsubsection{Tratamiento in vitro con OKA, OKB o $20 \mathrm{E}$}

Se utilizaron dos grupos de ninfas de $4^{\text {to }}$ estadio de aproximadamente una semana post ecdisis, bajo ayuno. En el primer grupo se silenció el gen precursor de todas las isoformas de OKs (dsOKs), siguiendo el protocolo que se describió anteriormente (polimerización del dsRNA e inyección). El segundo grupo fue inyectado el mismo día (48hs pre-alimentación) pero sólo con solución salina. Previamente al ensayo, se evaluó un gen ausente en los insectos ( $\beta$-lactamasa, resistencia al antibiótico ampicilina en bacterias), para el cual no se observaron diferencias durante el proceso de muda y ecdisis respecto de insectos inyectados sólo con solución salina.

El día 11 PBM, los insectos se disecaron bajo lupa, en solución salina estéril (intercalando insectos de ambos tratamientos para garantizar el análisis estadístico). Se pre-incubaron las muestras en $500 \mu l s$ de medio de insectos Grace $\left(\right.$ Sigma $\left.^{\circledR}\right)$, las cuales consistían en la cutícula inferior conteniendo SNC, tráqueas y cuerpo graso de cada insecto. Después de aproximadamente 30 minutos, se transfirió cada muestra a $500 \mu 1 \mathrm{~s}$ de medio Grace conteniendo uno de los distintos tratamientos. Cada tratamiento consistió en la aplicación al medio de insectos del péptido sintético de RhoprOKA, RhoprOKB (descriptos más arriba, inyección péptido sintético) o 20E a una concentración de $10^{-6} \mathrm{M}$. Para el grupo control se utilizó medio Grace. Después de incubar las muestras durante 3 horas a temperatura ambiente el medio fue reemplazado con reactivo $\operatorname{Tri}^{\circledR}$ (Sigma-Aldrich, Darmstadt, Alemania) y las muestras fueron guardadas a $-80^{\circ} \mathrm{C}$ hasta su utilización. 


\subsubsection{Análisis estadístico}

Los datos se sometieron a las pruebas para testear los supuestos de normalidad y homocedasticidad mediante estadísticos Shapiro-Wilks y de Levene respectivamente, excluyentes para la aplicación de modelos paramétricos. En los casos necesarios se aplicó transformación de los datos para obtener normalidad y homogeneidad de varianzas en el siguiente orden de aplicación: Ln $\mathrm{x} ; \sqrt[2]{x} ; \mathrm{x}^{2} \mathrm{y}^{1 / x}$. En caso de no obtenerse el resultado deseado con la primera transformación se procedía a la siguiente (Armitage 1992; McCleery 2007; Kaps 2009).

Para los análisis de resultados de qPCR se utilizó ANOVA de un factor. De ser necesario para las comparaciones post hoc, entre más de dos grupos, se utilizó el estadístico DMS. Los experimentos de EIA fueron analizados mediante ANOVA de 2 factores (factor 1: tratamiento; factor 2: días post alimentación). Para los análisis de correlación se utilizó el estadístico de Pearson (Sokal 1980; Field 2000; Majerowicz, Alves-Bezerra et al. 2011).

En caso de no lograrse los supuestos mediante la utilización de la transformaciones antes mencionadas, se utilizaron los estadísticos no paramétricos de $\mathrm{U}$ Mann-Whitney para la comparación de medias, y los índices de Tau-B de Kendall y Spearman para el análisis de correlación (Sokal 1980; Field 2000).

Todos los análisis estadísticos fueron realizados con el programa IBM SPSS Statistics ${ }^{\circledR}$ versión 22 . Una $\mathrm{p}<0,05$ se tomó como valor de diferencias significativas en todos los casos (Field 2000). 


\subsection{RESULTADOS y DISCUSIÓN}

\subsubsection{Perfil de expresión de RhoprOKA y RhoprOKB en el ciclo de muda}

Como primera aproximación al estudio de su función, se analizó el perfil de expresión de RhoprOKA y RhoprOKB en ninfas de $4^{\text {to }}$ estadio durante distintos tiempos del ciclo de muda, que se extendió entre una única ingesta de sangre a depleción y la consiguiente ecdisis, aproximadamente 12 días después. Para cada individuo se extrajo hemolinfa a fin de medir concentración de ecdisteroides, y se preparó ADNc de cuerpo completo para medir niveles de expresión de genes por qRT-PCR. Los resultados mostraron que los niveles más altos de expresión de RhoprOKA fueron los días 4, 8 y 12 post alimentación (PBM; del inglés post blood meal), significativamente más altos que el día 6, que es el día de expresión más baja ( $\mathrm{p}<0,05 ; \mathrm{n}=5-7)$. Además, el día 12 PBM (que es el día aproximado de ecdisis, \pm 2 días), los niveles de expresión de RhoprOKA se incrementan en una diferencia de 12,5 veces respecto del día 6 PBM (día de mínima expresión) (Fig. 2.8).

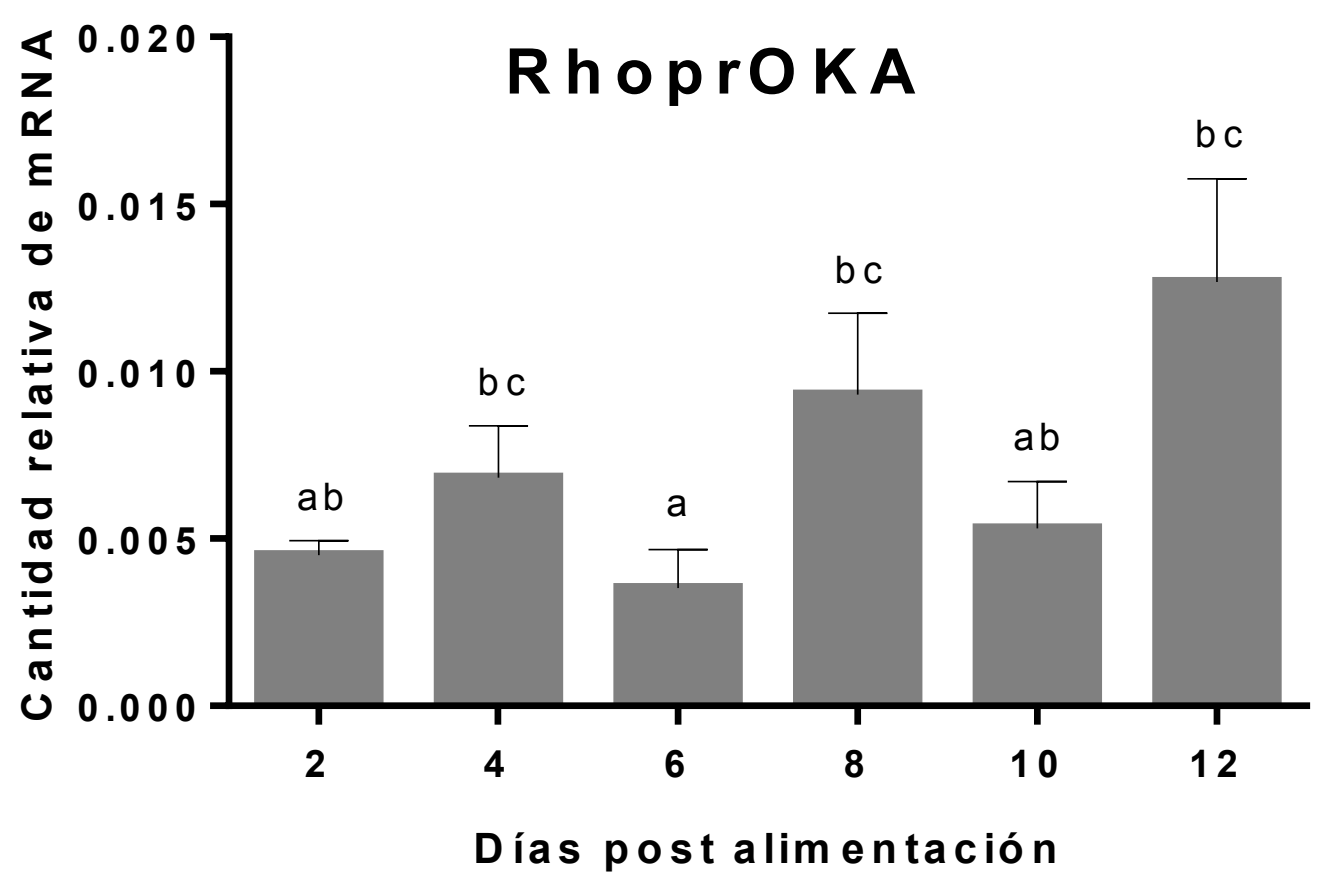

Figura 2.8: Expresión del transcripto RhoprOKA a distintos tiempos PBM. Las letras diferentes indican diferencias significativas $(\mathrm{p}<0,05 ; \mathrm{n}=5-7)$, ANOVA de un factor, post hoc DMS. 
Respecto a RhoprOKB, los niveles de expresión el día 12 PBM se incrementan significativamente $(\mathrm{p}<0,05 ; \mathrm{n}=5-7)$, en 5,8 y 12,5 veces respecto de los días 8 y 10 PBM respectivamente. Por otro lado, el día 10 PBM evidenció un incremento significativo respecto de la situación basal (días 2, 4 y 8) (p<0,05; n=5-7) (Fig. 2.9).

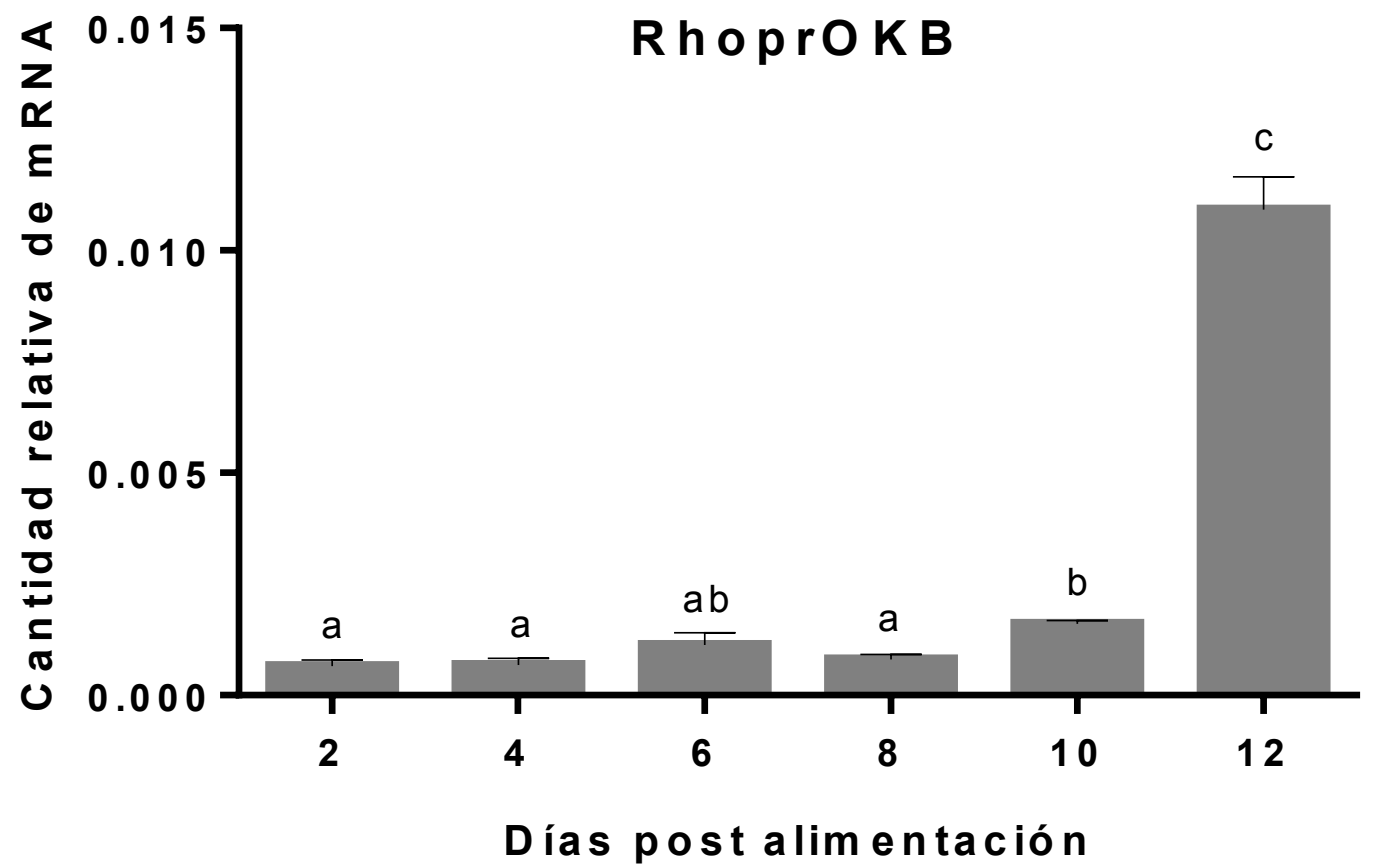

Figura 2.9: Expresión del transcripto RhoprOKB. Las letras diferentes indican diferencias significativas $(\mathrm{p}<0,05 ; \mathrm{n}=5-7)$, ANOVA de un factor, post hoc DMS.

Estos resultados constituyen la primera información sobre un perfil temporal de la expresión de OKs durante el ciclo de muda en insectos. Si bien ambos transcriptos se expresan durante todo el ciclo, la expresión aumenta significativamente en el momento de la ecdisis, en forma más marcada para RhoprOKB. En conjunto con otros resultados de fisiología molecular presentados en esta Tesis, los datos de expresión sugieren un posible papel de estos neuropéptidos durante la ecdisis (ver resultados subsiguientes).

\subsubsection{Análisis del rol funcional de RhoprOKs vía silenciamiento transcripcional} (RNAi)

Con el fin de determinar el papel fisiológico de RhoprOKs, abordamos una aproximación de pérdida de función por RNAi. Se inyectó un dsRNA que abarca todas 
las isoformas del gen, a fin de silenciarlas en conjunto (ver anexo, secuencias hormonas de la muda y sitio de unión de los primers utilizados).

Se utilizaron ninfas de $4^{\text {to }}$ y $5^{\text {to }}$ estadios que fueron inyectadas con a) $2 \mu \mathrm{gs}$ de dsRNA para OKs (grupo dsOKs); b) $2 \mu$ gs de dsRNA para un gen inespecífico ausente en $R$. prolixus (gen de resistencia a ampicilina) (grupo control ds-inespecífico) o c) $2 \mu \mathrm{ls}$ de solución salina (grupo control salina). Puesto que no existieron diferencias entre los dos grupos control, los individuos de ambos grupos fueron considerados un único grupo control.

Dos días después de las inyecciones, los insectos fueron alimentados sobre gallinas; no existieron diferencias en cuanto a la alimentación entre los grupos. Se midió la expresión de los transcriptos RhoprOKA y RhoprOKB y se pudo comprobar el correcto silenciamiento de la expresión del gen, mayor al 80\% (ver anexo, testeo del silenciamiento transcripcional del gen orcokinina, fig. 9 A-B).

Se observó a los individuos diariamente, desde la alimentación hasta el día esperado de la ecdisis (día 12 PBM). Los resultados indicaron que los insectos de los grupos dsOKs y control no se diferencian durante todo el ciclo, hasta el momento esperado de ecdisis. En ese momento, se produce la ecdisis normal en los grupos control. Sin embargo, los insectos que poseen niveles bajos de OKs no consiguieron realizar la ecdisis. Hacia el día 12 PBM comienzan a ralentizar sus movimientos y adoptan la posición de muda (sujetos al sustrato con la cabeza hacia abajo y el dorso ligeramente arqueado). Aproximadamente dentro de las 24hs después las ninfas se desprenden del sustrato y mueren (día 13 PBM) (Tabla 1). La observación detallada de los insectos que no consiguieron completar la muda indicó que la cutícula nueva estaba endurecida y oscurecida, un proceso que ocurre durante la post-ecdisis. Por lo tanto, se observa que la pre-ecdisis y la post-ecdisis ocurrieron en los insectos dsOKs, y que la falla fue durante la ecdisis (fig. 2.10). 


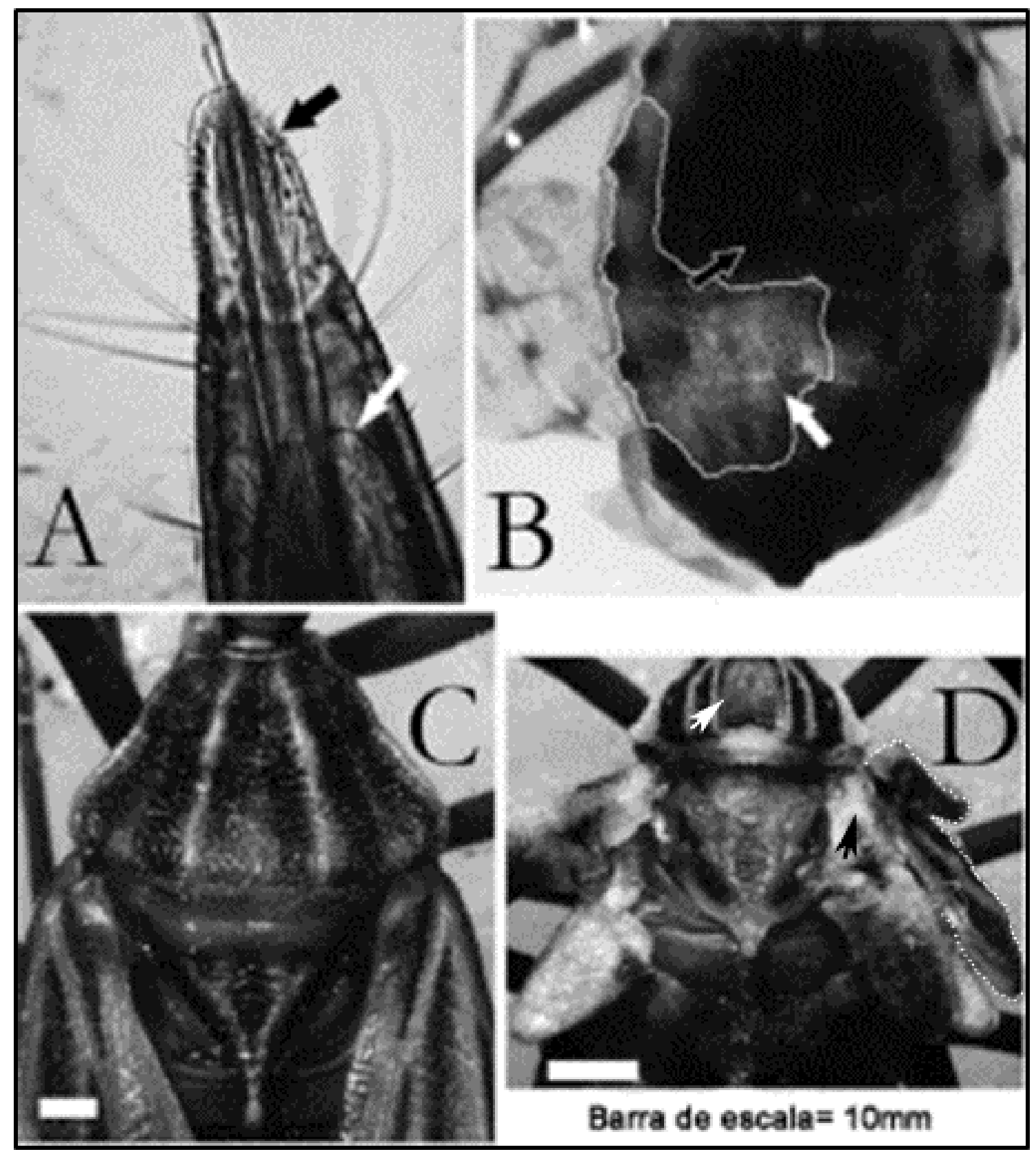

Figura 2.10: Ninfas de $4^{\text {to }}$ y $5^{\text {to }}$ estadio de R. prolixus tratadas con dsOKs. (A) Probóscide de una ninfa de $4^{\text {to }}$ estadio silenciada (flecha negra), por sobre la nueva probóscide de la ninfa de $5^{\text {to }}$ estadio que no logró emerger (flecha blanca). (B) La vieja cutícula (flecha negra) fue removida manualmente de una ninfa 4ta silenciada. Debajo de la misma se puede observar la nueva cutícula, delimitada por la línea punteada (flecha blanca), la cual ya se halla endurecida y oscurecida. (C) Vista dorsal del tórax de un adulto que mudó normalmente como ninfa de $5^{\text {to }}$ estadio sin silenciar. (D) Ninfa $5^{\text {to }}$ estadio silenciada que no completo la ecdisis. Nótese la apertura dorsal sobre el pronoto (flecha blanca), la cutícula endurecida del estado adulto y la base de las alas del adulto (flecha negra) por debajo de los esbozos alares de la ninfa $5^{\text {ta }}$ (línea blanca punteada).

Para descartar un efecto inespecífico de la inyección de dsOKs (acción sobre otro gen) se realizó un experimento similar al descripto, pero con otra estrategia de silenciamiento. En este caso se inyectaron conjuntamente (y por separado) dos dsRNAs 
específicos para RhoprOKA y RhoprOKB respectivamente $(2 \mu \mathrm{gs}$ de cada uno en $2 \mu \mathrm{ls}$ de solución salina). Mediante qRT-PCR comprobamos que con esta estrategia el silenciamiento de ambas isoformas del gen fue comparable con el conseguido con la inyección de un dsRNA que cubría ambas (ver anexo, testeo del silenciamiento transcripcional del gen orcokinina, figs. $9 \mathrm{C}-\mathrm{H}$ ). Los resultados obtenidos fueron similares a los descriptos más arriba, con lo que concluimos que el arresto de muda observado se debe al silenciamiento del gen RhoprOKs, y no a un efecto inespecífico del dsRNA sobre otro gen.

Con el fin de comprobar si el arresto de muda ocurría también en la muda ninfaadulto, o exclusivamente entre dos estadios ninfales, realizamos un experimento similar al descripto más arriba con ninfas de $5^{\text {to }}$ estadio. Nuevamente, no se observaron diferencias entre los grupos dsOKs y control hasta el momento de la ecdisis $(\approx$ día 20 PBM). Al mismo tiempo en que los insectos del grupo control comenzaron a mudar, los dsOKs dejaron de moverse y murieron sin mudar uno o dos días más tarde (Tabla 1, ver anexo, testeo del silenciamiento transcripcional del gen orcokinina, fig. 10). En algunos de ellos se observó la apertura en la región dorsal del tórax (Figura 2.10), que es el primer paso de la ecdisis en $R$. prolixus (Ampleford and Steel 1982) pero ninguno de los individuos tratados con dsOKs pudo completar una muda exitosa (Tabla 1).

\subsubsection{Silenciamiento transcripcional de orcokinina discriminando por isoforma (dsOKA y dsOKB)}

Una vez observado el papel de RhoprOKs en la regulación de la ecdisis, la siguiente pregunta experimental fue: ¿El arresto de muda es debido al silenciamiento de RhoprOKA y RhoprOKB de manera conjunta? ¿O una sola de las isoformas tiene un papel relevante en este proceso? Para abordarla, realizamos un silenciamiento específico para cada isoforma.

La aproximación experimental fue similar a la descripta en el punto anterior con ninfas de $4^{\text {to }}$ estadio, pero los insectos fueron inyectados con dsRNA específico para RhoprOKA (dsOKA) o para RhoprOKB (dsOKB). Los resultados mostraron que el grupo dsOKA se comporta exactamente igual al dsOKs: detención en los movimientos hacia el día 12 PBM y muerte sin completar la muda (Tabla 1). Sin embargo aquellos 
insectos inyectados con dsOKB lograron completar el proceso de ecdisis, aunque presentaron un retardo significativo $(\mathrm{p}<0,001 ; \mathrm{n}=13)$, en promedio de 2 días, respecto a los controles (Tabla 1). Los resultados sugieren que RhoprOKA es la isoforma que está centralmente involucrada en la regulación del proceso de ecdisis, mientras que el papel de RhoprOKB podría ser secundario o contributivo.

Tabla 1: Efecto del tratamiento experimental en nifas de $R$. prolixus respecto de la muda y la mortalidad

\begin{tabular}{|c|c|c|c|c|}
\hline \multirow[t]{2}{*}{ Tratamiento } & \multirow{2}{*}{ Estadío } & \multicolumn{2}{|c|}{ Fenotipo } & \multirow[t]{2}{*}{$\mathbf{n}$} \\
\hline & & Muda (Días P. A.) & Mortalidad (Días P. A.) & \\
\hline S. Salina & 4 to & $100 \%(12,3 \pm 0,63)$ & - & 39 \\
\hline ds $\beta$-Lac. & 4 to & $100 \%(12,9+0,42)$ & - & 20 \\
\hline ds OKs & 4 to & - & $100 \%(13,6 \pm 0,14)$ & 34 \\
\hline $\mathrm{ds} \mathrm{OKA}+\mathrm{dsOKB} / \mathrm{C}$ & 4 to & - & $100 \%(14,67 \pm 0,47)$ & 18 \\
\hline dsOKA & 4 to & - & $100 \%(14,18 \pm 0,37)$ & 17 \\
\hline ds OKB & 4 to & $100 \%(14,46+0,63) * * * *$ & - & 13 \\
\hline S. Salina & 5 to & $100 \%(19,4+0,35)$ & - & 5 \\
\hline ds OKs & 5to & - & $100 \%(21,5 \pm 1,77)$ & 6 \\
\hline
\end{tabular}

La diferencia observada entre ambas isoformas puede deberse a dos razones. En primer lugar RhoprOKA se expresa en forma temprana durante el ciclo de muda (Fig. 2.8). Esto podría afectar la expresión de hormonas como ETH y CZ (evaluado en ensayos posteriores). En cambio RhoprOKB, se expresa principalmente sobre final del ciclo de muda (Fig. 2.9).

En este sentido además, en los insectos B. mori, D. melanogaster y $M$. sexta, se observó que $\mathrm{EH}$ y $\mathrm{CZ}$ se expresan en las células ventromediales e ipsilaterales tipo-1 del cerebro respectivamente (Kono, Nagasawa et al. 1990; Zitnan, Hollar et al. 2002; Kim, Zitnan et al. 2006). En un trabajo previo de nuestro grupo de estudio, se reportó inmuno marcación positiva para RhoprOKA en ambos grupos de células (Sterkel 2011), sugiriendo una posible coexpresión con estas hormonas. En este sentido, futuros ensayos de colocalización entre ambos péptidos podrá determinar si existe una coexpresión conjunta. 


\subsubsection{Efecto de dsOKS sobre genes relacionados con la síntesis y liberación de ecdisteroides}

Una vez establecido un papel de RhoprOKs en la regulación de la ecdisis, nos propusimos estudiar los mecanismos fisiológicos de esta regulación. Dada la función central de ecdisteroides en la regulación de la ecdisis en insectos (Loof 2008; Loof, Boerjan et al. 2013), y antecedentes que sugirieron un efecto ecdisteroidotranscripcional in vitro de BommoOKA, planteamos la hipótesis de que RhoprOKs estuvieran involucradas en la síntesis de ecdisona.

En insectos pertenecientes a los grupos dsOKs y control, medimos los niveles de dos genes cuya expresión se ha asociado a la concentración de ecdisona en insectos: RhoprE75 (un gen de respuesta a ecdisona) y RhoprDis (Disembodied), implicado en su biosíntesis (Zhou, Hiruma et al. 1998; Bialecki, Shilton et al. 2002; Dubrovsky, Dubrovskaya et al. 2004; Wang, Wang et al. 2012; Matsumoto, Ueno et al. 2015). El gen E75 es un factor de transcripción que posee múltiples isoformas en insectos (A-E), siendo las isoformas A y B las más conservadas (Jindra, Sehnal et al. 1994; Palli, Ladd et al. 1997; Zhou, Hiruma et al. 1998). Pertenece a un grupo de genes denominados de respuesta temprana a ecdisteroides; se transcribe en forma rápida y transitoria en respuesta a la variación hemocélica de la concentración de ecdisteroides (Zhou, Hiruma et al. 1998). En R. prolixus E75 no ha sido caracterizado en forma completa a nivel de secuencia, y dado que poseemos una secuencia parcial no hacemos mención de isoforma, puesto que no es posible determinarla. El gen Disembodied pertenece a un grupo de genes denominados "Halloween Genes", los cuales codifican para una serie de enzimas citocromo P450s, encargadas (entre otros procesos) de la mono-oxidación (por hidroxilación) del colesterol o fitoesterol, en una serie sucesiva de compuestos hasta culminar con 20-HidroxiEcdisona (20E) (Christiaens, Iga et al. 2010; Iga and Smagghe 2010; Hentze, Moeller et al. 2013).

La expresión del gen RhoprE75 no presentó diferencias significativas entre los grupos control y dsOKs (Fig. 2.11 A), pero sí cuando las isoformas del gen son silenciadas separadamente (Figs. 2.18 A y 2.19 A). Por otra parte, los niveles de expresión de RhoprDis se incrementaron significativamente, ya sea en insectos silenciados para ambas isoformas en conjunto como por separado, tanto en el día 6 como en el día 11 PBM (Fig. 2.11 B, 2.18 B y 2.19 B). En principio, los resultados de 
RhoprE75 para el silenciamiento con dsOKs parecen contradictorios con el resto de los datos. Sin embargo, E75 se ha observado en algunas especies que responde negativamente a JH (Meiselman, Lee et al. 2017). Reportes recientes han demostrado que la hormona ETH (en combinación con 20E) regula positivamente la síntesis de JH en procesos asociados a la muda y ovogénesis en dípteros (Meiselman, Lee et al. 2017). Dado los antecedentes y resultados obtenidos, se determinó que en las condiciones de trabajo utilizadas, este gen no constituía un gen reportero de la concentración de ecdisteroides, adecuado para los fines del trabajo.
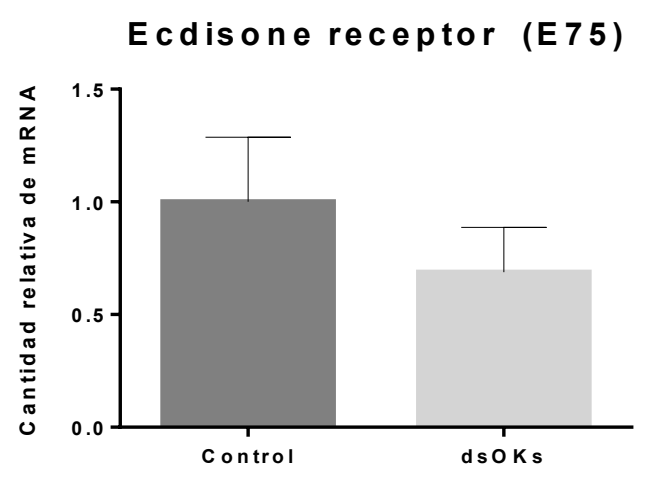

A

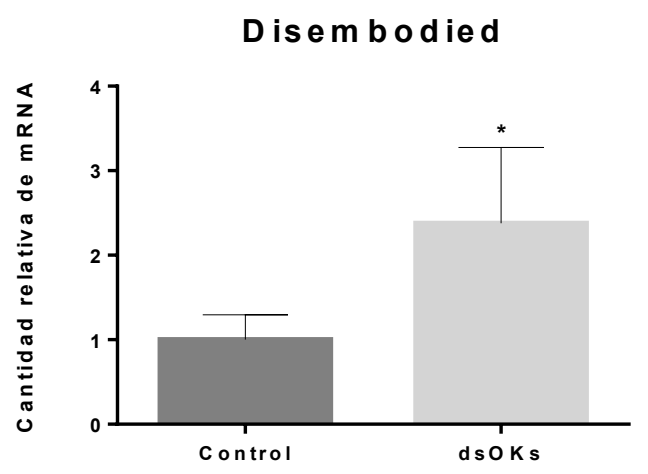

Figura 2.11: Expresión de (A) RhoprE75. (B) RhoprDis en ninfas de 4to estadio 6 días PBM en insectos control y silenciados para el gen $\operatorname{RhoprOKs}$ (dsOKs). (ANOVA de 1 factor $*=\mathrm{p}<0,05 ; \mathrm{n}=7$ ).

\subsubsection{Efecto de dsOKS sobre la concentración hemocélica de ecdisteroides}

Se afrontó el siguiente experimento a fin de estudiar el efecto del silenciamiento de RhoprOKs en la concentración hemocélica de ecdisona, como aproximación más directa para evaluar su efecto en la ecdisteroidogénesis. Para ello, se colectó hemolinfa para medir la concentración de ecdisteroides por ELISA competitivo (EIA), utilizando los mismos insectos en los cuales se evaluó la expresión de orcokininas (ver punto "Perfil de expresión de RhoprOKA y RhoprOKB en el ciclo de muda"). Tanto en el grupo control como en el dsOKs observamos que la concentración de $20 \mathrm{E}$ se incrementó posteriormente a la ingesta, con un pico en el día 6 PBM, luego de lo cual regresó paulatinamente a niveles basales hasta el momento de la ecdisis (Fig. 2.12). Estos resultados son congruentes con lo publicado previamente (Garcia, Feder et al. 1987; Garcia 1988). Sin embargo, la concentración máxima fue aproximadamente 2,5 veces superior a la observada en la bibliografía (Garcia, Feder et al. 1987; Garcia 1988). 
Esta diferencia puede deberse al uso de distintas técnicas de medición, que difieren en el grado de sensibilidad en la detección de ecdisteroides totales (Es) y 20E. La técnica de radio inmuno ensayo utilizada en los trabajos citados (RIA; del inglés radio immuno assay) detecta preferentemente $20 \mathrm{E}$ por sobre Es en una proporción de aproximadamente 2,5:1 (Yamanaka, Hua et al. 2005). Por otro lado, el ELISA Competitivo (EIA) desarrollado en el presente trabajo detecta todo tipo de ecdisteroides circulantes (principalmente ecdisona, 20E, y 2-deoxiecdisona) (Delbecque, Lanzrein et al. 1978; Pascual, Belles et al. 1995).

\section{Ecdisteróides totales (Hemolinfa)}

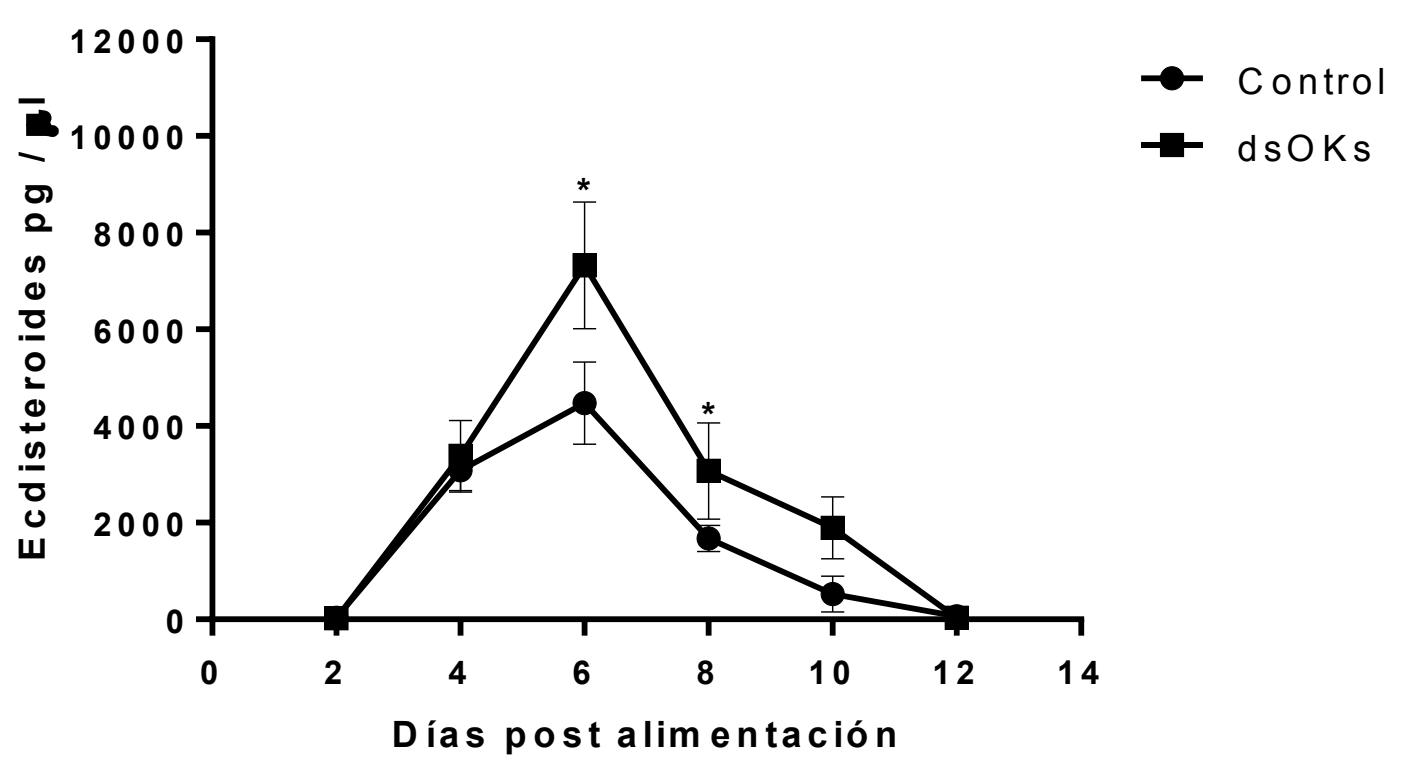

Figura 2.12: Concentración hemocélica de ecdisteroides en insectos control y para el gen orcokinina (dsOKs). ANOVA de un factor, comparación individual por día. * =p<0,05; n=5-10).

Los resultados revelaron que el silenciamiento de RhoprOKs produce un aumento significativo en la concentración de ecdisteroides en hemolinfa en los días 6 PBM (pico de concentración) y 8 PBM (Fig. 2.12) En concordancia con los resultados obtenidos para la medición de expresión de genes marcadores (ver punto anterior) esto sugiere un papel ecdisteroidostático para RhoprOKs. 
Un trabajo previo reportó un papel ecdisteroido-transcripcional in vitro para OKA en B. mori (Yamanaka, Roller et al. 2011). Si bien estos resultados van en dirección contraria a los nuestros, se ha reportado que neuropéptidos ortólogos tienen efectos opuestos con dependencia de la especie. Por ejemplo, la hormona peptídica sNPF (short neuropeptide $F$ ) que modula el comportamiento alimentario en distintas especies, tiene efecto opuesto en A. mellifera y D. melanogaster (orexitranscripcional) que en la langosta $S$. gregaria (anti orexitranscripcional) (Dillen, Verdonck et al. 2014). Un caso similar podría darse para OKA en $R$. prolixus y $B$. mori.

Nuestros datos de IHQ, (ver Capítulo 1) y previamente publicados (Wulff, Sierra et al. 2017), también parecen apuntar a un posible papel de RhoprOKs en regulación de la esteroidogénesis. Las células “de reloj” (ubicadas en la medula accesoria del cerebro) (Vafopoulou, Terry et al. 2010), las cuales regulan procesos circadianos, presentaron inmunoreactividad para OKA y OKB en R. prolixus (Wulff, Sierra et al. 2017). Se ha demostrado que la concentración hemocélica de $20 \mathrm{E}$ y la expresión del receptor EcR están reguladas de manera circadiana (ambos aumentan en las horas nocturnas) (Vafopoulou and Steel 2006; Vafopoulou and Steel 2012). Además hemos observado marcación positiva en tejidos implicados en la síntesis de E y 20E. Detectamos marcación en gónadas, únicas estructuras encargadas de sintetizar E en adultos, y además en para RhoprOKB/C en intestino medio, tejido implicado en la conversión de E en 20E en ninfas y adultos (ver Capítulo 1 y Wulff, Sierra et al. 2017)).

Los resultados expuestos, junto a experimentos posteriores (ver más adelante), sugieren la hipótesis de que RhoprOKs regulan negativamente la síntesis de ecdisona. Además, la síntesis y liberación de ambos factores (OKs y 20E), podría estar asociada a un ritmo circadiano.

\subsubsection{Efecto de los ecdisteroides en la expresión de RhoprOKA y RhoprOKB}

Los resultados presentados nos sugirieron un papel de RhoprOKs en la regulación de la síntesis de ecdisona. Por vías de retroalimentación frecuentes en la regulación endócrina, la ecdisona podría a su vez tener efectos en la síntesis de RhoprOKA y/o RhoprOKB. Para probar esta hipótesis realizamos un experimento in 
vivo (inyección de ecdisona) y otros con un preparado in vitro, que se describen a continuación.

Se inyectaron ninfas de $4^{\text {to }}$ estadio (ayunadas, una semana post ecdisis) con $10 \mu \mathrm{gs} / 2 \mu \mathrm{ls}$ de $20 \mathrm{E}$ disuelta en solución salina, o $2 \mu 1 \mathrm{~s}$ de solución salina (grupo control). Se midieron los niveles de expresión de los transcriptos RhoprOKA y RhoprOKB en ambos grupos seis días más tarde, a fin de evaluar el efecto de 20E en la expresión de RhoprOKA y RhoprOKB. Este tiempo fue seleccionado porque, en experimentos anteriores (ver más arriba), habíamos observado que la concentración maxima de ambas isoformas se produce seis días después del pico de ecdisona (Figs. 2.8 y 2.9). No se observaron diferencias significativas entre insectos inyectados con $20 \mathrm{E}$ y solución salina (Figura 2.13 A y B).

RhoproKA

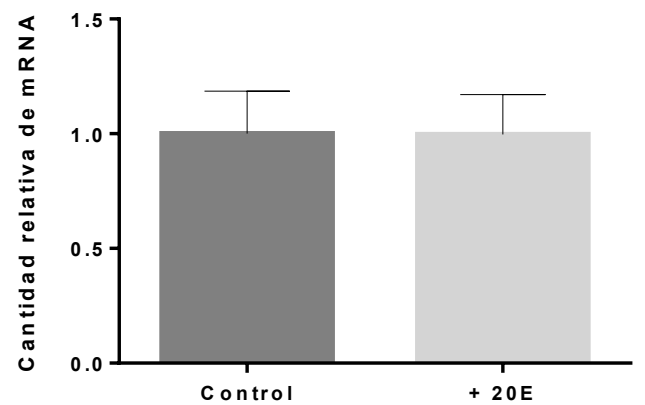

A

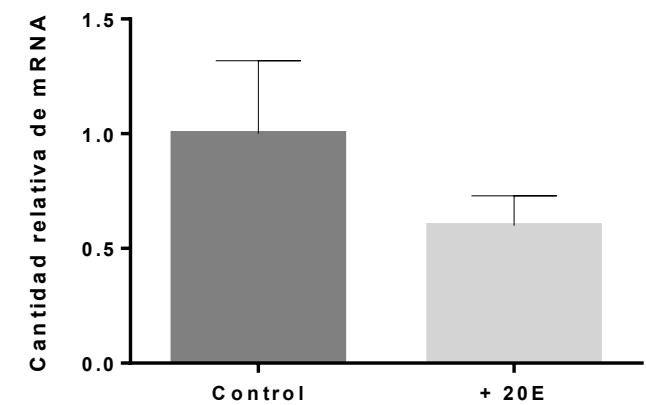

Figura 2.13: Efecto de la inyección de 20E sobre la expresión de RhoprOKA (A) y RhoprOKB (B) en ninfas de $4^{\text {to }}$ estadio Los controles fueron inyectados con s. salina.

\subsubsection{Inyecciones de $\mathrm{OKA}, \mathrm{OKB}$ y $20 \mathrm{E}$ : intento de rescate de la muda en insectos silenciados para RhoprOKs}

\subsubsection{Rescate por inyección de péptido sintético (RhoprOKA y RhoprOKB)}

Como estrategia para intentar revertir el arresto de muda observado en insectos silenciados para RhoprOKs se procedió a la inyección de los péptidos sintéticos RhoprOKA y RhoprOKB (las secuencias de cada péptido se detallan en el Cap. 1). Las inyecciones fueron realizadas sobre insectos silenciados para RhoprOKs (dsOKs), en días clave del ciclo de muda: día 6 PBM (pico de ecdisona) y 11 PBM (previo a la 
ecdisis). En ningún caso se revirtió el arresto de muda respecto de los insectos del grupo control (silenciados para RhoprOKs sin inyección de péptido sintético) (Tabla 2).

Tabla 2: Efecto del tratamiento experimental (inyección péptido sintético) en nifas de $R$. prolixus respecto de la muda y la mortalidad

\begin{tabular}{|c|c|c|c|c|}
\hline \multirow[t]{2}{*}{ Tratamiento experimental } & Estadío & \multicolumn{2}{|r|}{ Fenotipo } & \multirow[t]{2}{*}{$\mathbf{n}$} \\
\hline & & Muda (Días P. A.) & Mortalidad (Días P. A.) & \\
\hline \multicolumn{5}{|l|}{ Día 6 PBM } \\
\hline S. Salina + S. Salina (2uls) & 4to & $100 \%(12,0 \pm 0,00)$ & - & 4 \\
\hline S. Salina + RhoprOKA (100uM) & 4to & $100 \%(12,0 \pm 0,00)$ & - & 4 \\
\hline S. Salina + RhoprOKB (100uM) & 4to & $100 \%(12,5 \pm 0,35)$ & - & 4 \\
\hline S. Salina + RhoprOKA+B (100uM) & 4to & $100 \%(12,0 \pm 0,00)$ & - & 4 \\
\hline ds OKs + S. Salina (2uls) & 4to & $75 \%(14,0+0,00)$ & $25 \%(12,33+0,35)$ & 4 \\
\hline dsOKs + RhoprOKA (100uM) & 4to & $75 \%(12,0+0,00)$ & $25 \%(17,00 \pm 2,13)$ & 4 \\
\hline dsOKs + RhoprOKB (100uM) & 4to & - & $100 \%(15,50 \pm 1,75)$ & 4 \\
\hline $\mathrm{dsOKs}+$ RhoprOKA+B $(100 \mathrm{uM})$ & 4to & - & $100 \%(13,67 \pm 0,35)$ & 4 \\
\hline
\end{tabular}

\section{Día 11 PBM}

\begin{tabular}{lcccc} 
S. Salina + S. Salina (2uls) & 4to & $100 \%(15,11 \pm 0,61)$ & - & 9 \\
S. Salina + RhoprOKA $(100 \mathrm{uM})$ & 4 to & $100 \%(14,67 \pm 0,51)$ & - & 9 \\
S. Salina + RhoprOKB $(100 \mathrm{uM})$ & 4 to & $100 \%(14,56 \pm 0,57)$ & - & 9 \\
S. Salina + RhoprOKA+B $(100 \mathrm{uM})$ & 4 to & $100 \%(14,90 \pm 0,56)$ & - & 10 \\
dsOKs + S. Salina (2uls) & 4 to & - & $100 \%(14,90 \pm 0,51)$ & 10 \\
dsOKs + RhoprOKA (100uM) & 4 to & - & $100 \%(14,30 \pm 0,46)$ & 10 \\
dsOKs + RhoprOKB $(100 \mathrm{uM})$ & 4 to & $11,1 \%(14,00 \pm 0,00)$ & $88,9 \%(13,78 \pm 0,47) *$ & 9 \\
dsOKs + RhoprOKA+B $(100 \mathrm{uM})$ & 4 to & $11,1 \%(15,00 \pm 0,00)$ & $88,9 \%(14,11 \pm 0,33)$ & 9 \\
\hline
\end{tabular}

$*=\mathrm{p}<0,05$ respecto a insectos inyectados con S. Salina + S. salina.

La inyección de OKB sintético aceleró significativamente la muda en los inyectados con solución salina y la muerte en dsOKs $(\mathrm{p}<0,05 ; \mathrm{n}=9)$ (Tabla 2). El hecho de que RhoprOKB acelere el proceso de ecdisis sobre el fin del ciclo de muda podría relacionarse con una interacción positiva entre RhoprOKB y RhoprCCAP (ver más adelante indicios experimentales en ese sentido). RhoprCCAP no sólo constituye una hormona central den ciclo de muda, sino que es un péptido cardioacelerador circulante en hemolinfa en muchas especies, incluida R. prolixus (Lee and Lange 2011). Esto podría favorecer la mayor diseminación de péptidos en el hemocele. El resto de las diferencias observadas no resultaron estadísticamente significativas.

Por más que es una aproximación usual en neuroendocrinología de insectos (Kim, Zitnan et al. 2006; Kim, Zitnan et al. 2006; Lenaerts, Van Wielendaele et al. 
2016; Hou, Jiang et al. 2017; Lenaerts, Cools et al. 2017), la inyección de péptidos sintéticos es compleja por distintos motivos, entre los que pueden enumerarse: la acción de peptidasas que degradarían los péptidos antes de que lleguen a los sitios blanco (Zhao, Yu et al. 2001; Zhao, Mita et al. 2001; Harrison and Bonning 2010); la presencia de otros péptidos dentro del precursor, distintos al que se inyecta; la imposibilidad de imitar las concentraciones y tiempos que ocurren con la expresión génica fisiológica. Por lo tanto, consideramos que los resultados negativos son debidos a dificultades experimentales, y no a una falta de acción de RhoprOKs sobre la muda, que fue reiteradamente comprobada a lo largo de todo nuestro trabajo experimental. Podrían ensayarse inyecciones en distintos días, a distintas concentraciones y combinaciones de péptidos, pero la inyección de péptidos in vivo es de todas maneras una aproximación laboriosa y compleja, con resultados difíciles de interpretar.

\subsubsection{Inyección de $20 \mathrm{E}$}

Dada la interacción entre ecdisteroides y RhoprOKs (ver más arriba), ensayamos si una inyección de $20 \mathrm{E}$ era capaz de revertir el efecto en la muda y ecdisis del silenciamiento de RhoprOKs.

Se seleccionaron dos días clave en la regulación endócrina de la muda, de acuerdo con la concentración fisiológica de $20 \mathrm{E}$ en hemolinfa dentro del ciclo de muda: una única inyección el día 4 y otra el día 6 PBM (justo antes y durante el pico de ecdisteroides). Los resultados demuestran que en ningún caso se revirtió el arresto de muda (Tabla 3). Sin embargo, la inyección de $10 \mu \mathrm{gs}$ de 20E aceleró significativamente el ciclo de muda $(\mathrm{p}<0,05 ; \mathrm{n}=5)$ en los controles, y de muerte en los grupos dsOKs $(\mathrm{p}<0,05 ; \mathrm{n}=13)$ (Tabla 3$)$. Para las otras concentraciones, si bien se observó una tendencia similar, ésta no resultó significativa (Tabla 3). 
Tabla 3: Efecto del tratamiento experimental (rescate con 20E) en nifas de $R$. prolixus respecto de muda y la mortalidad

\begin{tabular}{|c|c|c|c|c|}
\hline \multirow[t]{2}{*}{ Tratamiento experimental } & \multirow{2}{*}{ Estadío } & \multicolumn{2}{|c|}{ Fenotipo } & \multirow[t]{2}{*}{$\mathbf{n}$} \\
\hline & & Muda (Días P. A.) & Mortalidad (Días P. A.) & \\
\hline S. Salina + S. Salina (2uls) & 4to & $100 \%(13,5+0,62)$ & - & 10 \\
\hline S. Salina $+20 \mathrm{E}(2 \mathrm{uls} 5$ ugs totales $)$ & 4to & $100 \%(13,0+0,37)$ & - & 5 \\
\hline S. Salina $+20 \mathrm{E}(2 \mathrm{uls} 10 \mathrm{ugs}$ totales $)$ & 4to & $100 \%(12,3+0,35)^{*}$ & - & 5 \\
\hline dsOKs + S. Salina $(2 \mathrm{uls})$ & 4 to & - & $100 \%(13,2 \pm 0,7)$ & 13 \\
\hline ds OKs $+20 \mathrm{E}(2 \mathrm{uls} 5 \mathrm{ugs}$ totales $)$ & 4to & - & $100 \%(12,5 \pm 0,49)$ & 11 \\
\hline $\mathrm{ds} O K s+20 \mathrm{E}(2 \mathrm{uls} 10 \mathrm{ugs}$ totales $)$ & 4to & - & $100 \%(12,2 \pm 0,45) \&$ & 13 \\
\hline
\end{tabular}

$*=\mathrm{p}<0,05$ respecto a insectos inyectados con S. Salina + S. salina; $\&=\mathrm{p}<0,05$ respecto a insectos

inyectados con dsOKs + S. Salina

La aceleración significativa del ciclo como consecuencia de la inyección de las concentraciones más elevadas de 20E el día 4 PBM puede deberse a un adelanto en la síntesis de las hormonas disparadoras de la ecdisis, que responden a un pico de ecdisona (que en este estadio ocurre el día 6 PBM) (Zitnanova, Adams et al. 2001). Consideramos que el incremento de concentración de 20E el día 4 PBM (primera inyección) por sobre los valores normales podría haber favorecido la síntesis de estas hormonas. Como antecedente, en $M$. sexta, se observó que una inyección precipitada de la hormona ETH aceleró el proceso de ecdisis significativamente (Zitnan, Ross et al. 1999; Zitnan and Adams 2000).

\subsubsection{Papel fisiológico de neuropéptidos reguladores de la muda en insectos.}

En insectos holometábolos, principalmente dípteros y lepidópteros, la red peptidérgica de regulación de la ecdisis ha sido bien estudiada (Zitnan 2012). Brevemente, en lepidópteros el neuropéptido CZ comienza la secuencia de ecdisis al estimular la síntesis y liberación de ETH desde células epitraqueales (Kim, SpalovskaValachova et al. 2004; Zitnan, Kim et al. 2007). ETH propicia la síntesis y liberación de EH, que retroalimenta positivamente la liberación de ETH (Gammie and Truman 1999; Kim, Zitnan et al. 2006; Zitnan, Kim et al. 2007). La liberación de EH y ETH a hemolinfa origina la activación de la red de regulación hormonal que produce CCAP, entre otros neuropéptidos reguladores de la ecdisis (Kim, Zitnan et al. 2006; Kim, Zitnan et al. 2006; Zitnan, Kim et al. 2007; Arakane, Li et al. 2008). El modelo descripto, sin embargo, no ha sido demostrado hasta el momento en hemimetábolos, 
aunque existen pocos y recientes trabajos que sugieren que estaría conservado; se demostró que ETH y CCAP están involucrados en la regulación de la ecdisis en $S$. gregaria y R. prolixus respectivamente (Lee, Orchard et al. 2013; Lenaerts, Cools et al. 2017). En esta parte del trabajo nos propusimos estudiar la red peptidérgica de regulación de la ecdisis en $R$. prolixus, y posteriormente, analizar la participación de RhoprOKs en dicha red.

\subsubsection{Perfil de expresión de los neuropéptidos RhoprETH, RhoprEH y RhoprCZ durante el ciclo de muda}

La primera aproximación experimental en esta parte del trabajo fue medir la expresión a nivel de transcripto de los neuropéptidos RhoprETH, RhoprEH y RhoprCZ (Fig. 2.14 A, B y C) en ninfas de $4^{\text {to }}$ estadio durante distintos tiempos del ciclo de muda. No incluimos RhoprCCAP en el análisis puesto que este dato había sido publicado previamente (Lee, Orchard et al. 2013; Lee, Vanden Broeck et al. 2013).

Se observó un aumento en el nivel de expresión de RhoprETH en los días 6, 10 y 12 PBM. Se destacan los días 6 y 12, ya que el primero coincide con la máxima concentración hemocélica de ecdisteroides, y el segundo es inmediatamente anterior a la ecdisis (Fig. 2.14 B). Los datos son coincidentes con la bibliografía para insectos holometábolos tales como B. mori, M. sexta y D. melanogaster (Zitnan, Kingan et al. 1996; Adams and Zitnan 1997; Kingan, Gray et al. 1997; Park, Zitnan et al. 1999; Zitnan, Hollar et al. 2002; Kim, Zitnan et al. 2006; Kim, Zitnan et al. 2006; Roller, Zitnanova et al. 2010). Los días 10 y 12 PBM evidenciaron un incremento significativo respecto del día 8 (mínima expresión dentro del ciclo), en más de 13,5 veces $(\mathrm{p}<0,05$ $\mathrm{n}=5-7)$ y más de 18 veces $(\mathrm{p}<0,05 \mathrm{n}=5-7)$ respectivamente (Fig. $2.14 \mathrm{~B})$.

Se observó un aumento significativo en el nivel de expresión de RhoprEH en los días 10 y 12 PBM respecto del día 8, en más de 6,5 veces $(\mathrm{p}<0,05 \mathrm{n}=5-7)$, y casi 20 veces $(\mathrm{p}<0,05 \mathrm{n}=5-7)$ respectivamente (Fig. 2.14 A). Este resultado coincide con lo publicado para especies holometábolas, donde la máxima expresión del neuropéptido se observó durante la pre-ecdisis y ecdisis (Zitnan, Kim et al. 2007; Arakane, Li et al. 2008). 
Si bien no se observó un aumento significativo tanto para RhoprETH y RhoprEH durante los días 4, 6 y 8 PBM, coincidente con el pico de ecdisteroides (Fig. 2.14 A y B), el índice de correlación de Pearson entre ambas hormonas resulta significativo con un valor de $0,80(\mathrm{p}<0,01 ; \mathrm{n}=5)$. Si se considera el ciclo de muda completo (días 4-12 PBM), el índice asciende a un valor de 0,87 $(\mathrm{p}<0,01 ; \mathrm{n}=5-7)$. Este resultado podría sugerir que, al igual que lo demostrado para holometábolos (Gammie and Truman 1999; Zitnan, Kim et al. 2007; Chang, Yang et al. 2009), ETH y EH tienen una interacción positiva en $R$. prolixus.

Para RhoprCZ se observó un aumento significativo en el nivel de expresión en el día 12 PBM, más de 1,2 veces respecto al día 10 PBM. En M. sexta se reportó que la disminución en la concentración hemocélica de $20 \mathrm{E}$ se relaciona con la liberación de corazonina (CZ) a partir de las neuronas ipsilaterales tipo-1 del cerebro (Kim, Spalovska-Valachova et al. 2004). Podría darse un caso similar en $R$. prolixus, donde el regreso a niveles basales de $20 \mathrm{E}$ el día 12 PBM se relaciona con un aumento en la síntesis de RhoprCZ.
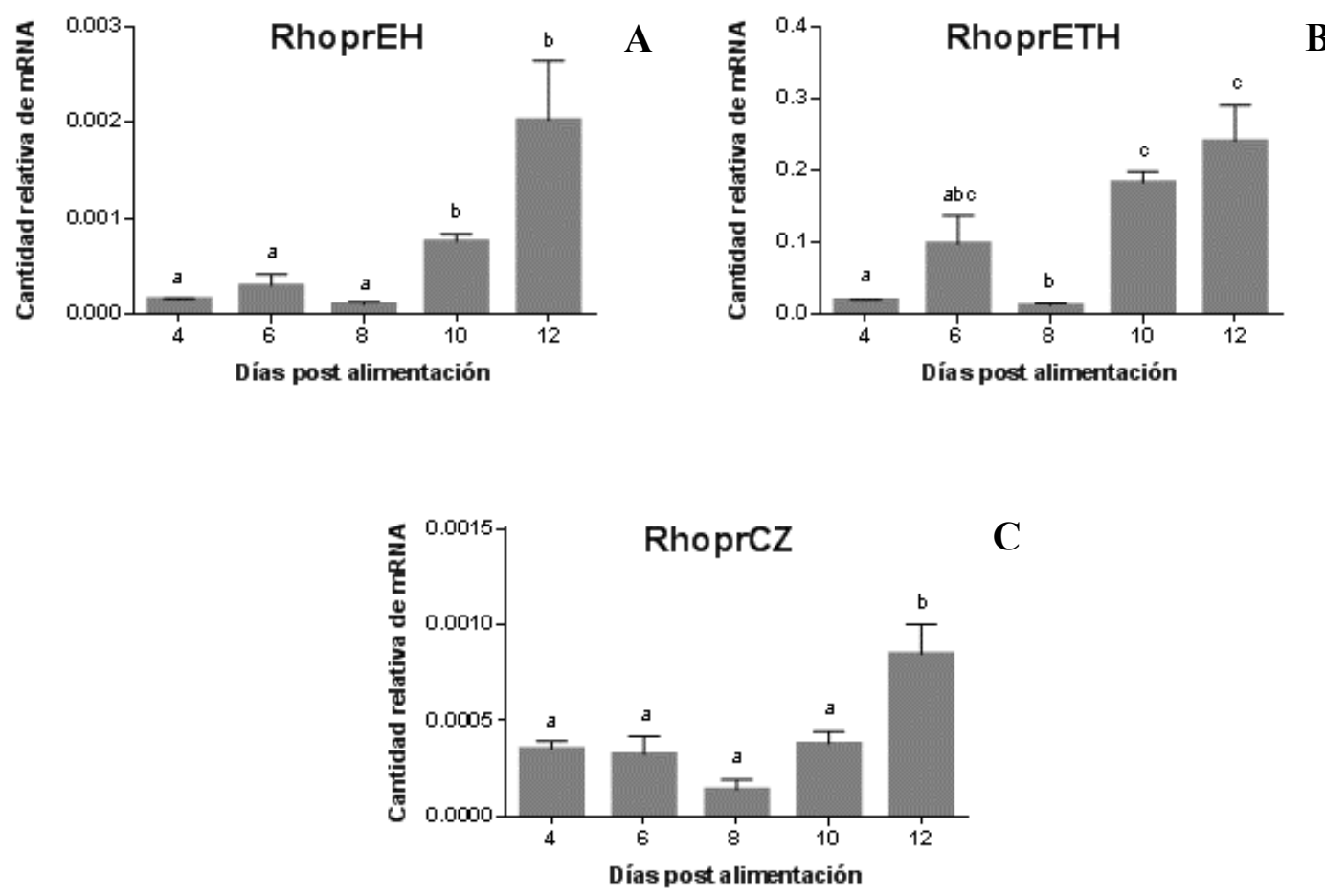

Figura 2.14: Medición de la expresión a nivel de transcripto total en ninfas de $4^{\text {to }}$ estadio 4-12 días PBM, en insectos silenciados no silenciados para el gen de orcokinina. (A) RhoprEH (B) RhoprETH (C) RhoprCZ. Letras diferentes indican un nivel de significación de $(\mathrm{p}<0,05 ; \mathrm{n}=5-7)$, ANOVA un factor, post hoc DMS. 


\subsubsection{Silenciamiento transcripcional RhoprETH, RhoprEH y RhoprCZ}

Como siguiente paso en el estudio de la función de neuropéptidos relacionados con la ecdisis, se procedió al silenciamiento transcripcional por RNAi de RhoprETH, RhoprEH y RhoprCZ. Se inyectó a los insectos con $2 \mu$ gs de dsRNA para cada uno de los genes estudiados, en una aproximación similar a lo realizado para RhoprOKs.

Los grupos dsETH y dsCZ, de manera similar a lo observado para dsOKs, se alimentaron y vivieron normalmente hasta el día 12 PBM, en que los insectos del grupo control realizaron efectivamente la ecdisis. Sin embargo, los pertenecientes a los grupos dsCZ y dsETH dejaron de moverse hacia el día 12 PBM, y murieron sin mudar 1-2 días más tarde. Los insectos del grupo dsEH consiguieron mudar, aunque con un retraso significativo $(\mathrm{p}<0,001 ; \mathrm{n}=6$ ) (Tabla 4). Esto sugiere un papel central de ETH y CZ en la ecdisis, igual que en especies de insectos holometábolos tales como M. sexta (Kim, Spalovska-Valachova et al. 2004; Zitnan, Kim et al. 2007), y el díptero tefrítido $B$. dorsalis (Hou, Jiang et al. 2017).

En un trabajo donde se abordó el silenciamiento del receptor de $\mathrm{CZ}$ en $R$. prolixus no se registraron defectos en la muda (Hamoudi, Lange et al. 2016). Sin embargo, consideramos que las diferencias entre los resultados presentes y los publicados son debidas a la aproximación experimental. En el trabajo citado, las inyecciones de dsCZR son realizadas el día 10 PBM (dos días antes de la ecdisis), en cambio en nuestro trabajo las inyecciones son realizadas antes del inicio del ciclo, dos días antes de la alimentación. Así, mientras en el segundo caso el sistema es interrumpido durante todo el ciclo, probablemente el día 10 PBM es demasiado tarde para interrumpir la expresión génica que permitirá la ecdisis exitosa dos días después. De hecho, resultados no publicados de nuestro grupo demuestran que si la inyección de dsOKs se realiza el día 11 PBM el fenotipo de arresto de muda no se registra. 
Tabla 4: Efecto del tratamiento experimental en nifas de $R$. prolixus respecto de la muda y la mortalidad

\begin{tabular}{lcccc}
\hline Tratamiento & Estadío & \multicolumn{2}{c}{ Fenotipo } & \multirow{2}{*}{ n } \\
\cline { 3 - 5 } & & Muda (Días P. A.) & Mortalidad (Días P. A.) & \\
\hline S. Salina & 4 to & $100 \%(14,5 \pm 0,35)$ & - & 8 \\
dsEH & 4 to & $100 \%(15,5 \pm 0,46)^{*}$ & - & 6 \\
dsCZ & 4 to & - & $100 \%(17,83 \pm 0,82)$ & 6 \\
\hline S. Salina & 4 to & $100 \%(12,7 \pm 0,18)$ & - & 14 \\
dsETH & 4 to & - & $100 \%(12,7 \pm 0,18)$ & 12 \\
\hline
\end{tabular}

$*=\mathrm{p}<0,001$ respecto a insectos inyectados con S. Salina.

Por otro lado, CZ no parece ser un factor regulador de la ecdisis en $D$. melanogaster y T. castaneum (Kim, Zitnan et al. 2006; Arakane, Li et al. 2008), de hecho está ausente en el genoma del coleóptero (Li, Predel et al. 2008; Richards, Gibbs et al. 2008). Tampoco se registró arresto de muda en el silenciamiento transcripcional de CZ o su receptor en las langostas $S$. gregaria y L. migratoria (Sugahara, Tanaka et al. 2017), lo cual podría indicar que $\mathrm{CZ}$ no es un regulador de la ecdisis en todas las especies de insectos.

Por otra parte, ETH sí parece ser una hormona central en la regulación de la ecdisis, con un papel conservado en todas las especies en las que se la ha estudiado, tanto holometábolos: D. melanogaster, M. sexta y T. castaneum (Kim, Zitnan et al. 2006; Zitnan, Kim et al. 2007; Arakane, Li et al. 2008); como hemimetábolos: $R$. prolixus y $S$. gregaria (el presente trabajo, (Lenaerts, Cools et al. 2017)). El silenciamiento transcripcional de ETH conduce en todos los casos de arresto del proceso de muda.

En insectos de los grupos control, dsCZ, dsETH y dsEH, se midió además la expresión de los transcriptos RhoprETH, RhoprEH, RhoprCZ, RhoprCCAP, RhoprOKA, RhoprOKB y RhoprDis, como aproximación para estudiar como afecta el silenciamiento de cada gen, tanto a la ecdisona como a otros componentes de la red peptidérgica de regulación de la ecdisis. Se realizaron dos mediciones sobre muestras del mismo experimento, unas colectadas el día 6 y otras el día 11 PBM (Figs. 2.15 y 2.16). 

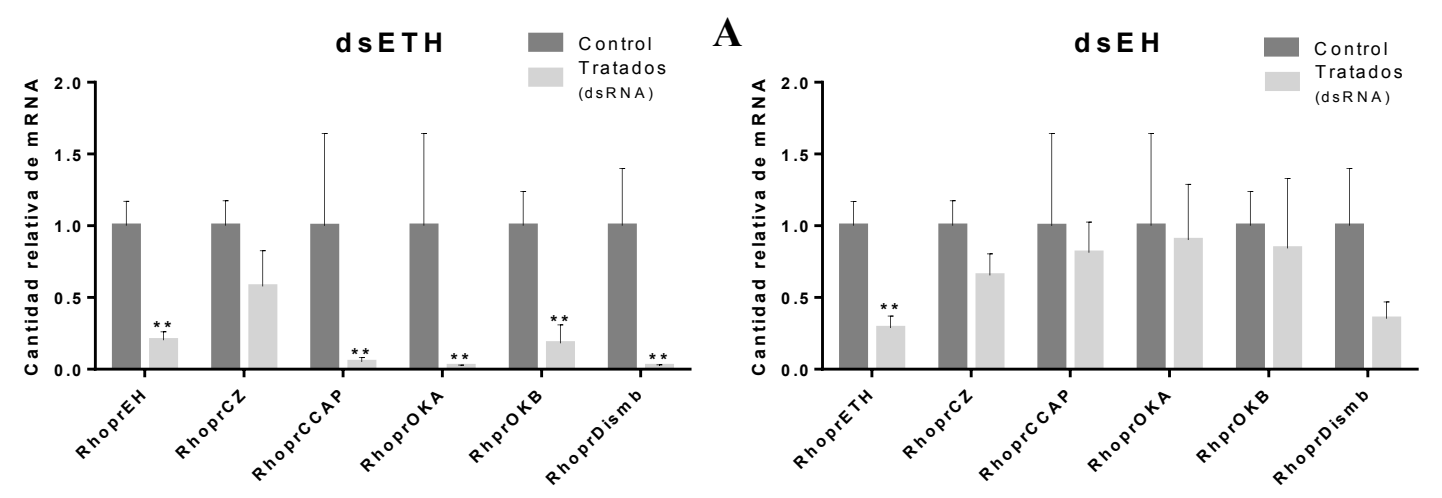

B

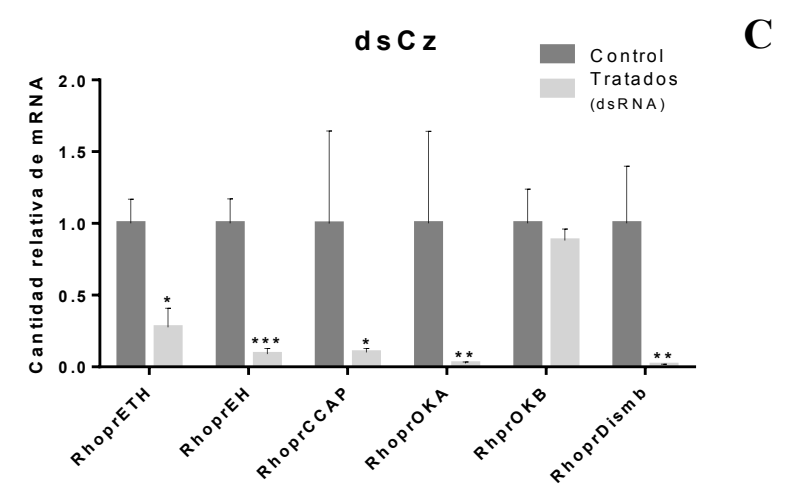

Figura 2.15: Expresión de transcriptos de neuropéptidos asociados a la muda, en ninfas de $4^{\text {to }}$ estadio 6 días PMB, en insectos silenciados para diferentes hormonas. (A) RhoprETH (B) RhoprEH (C) RhoprCZ. ANOVA de un factor; $*=\mathrm{p}<0,05 ; * *=\mathrm{p}<0,01 ; * * *=\mathrm{p}<0,001 ; \mathrm{n}=6$. 

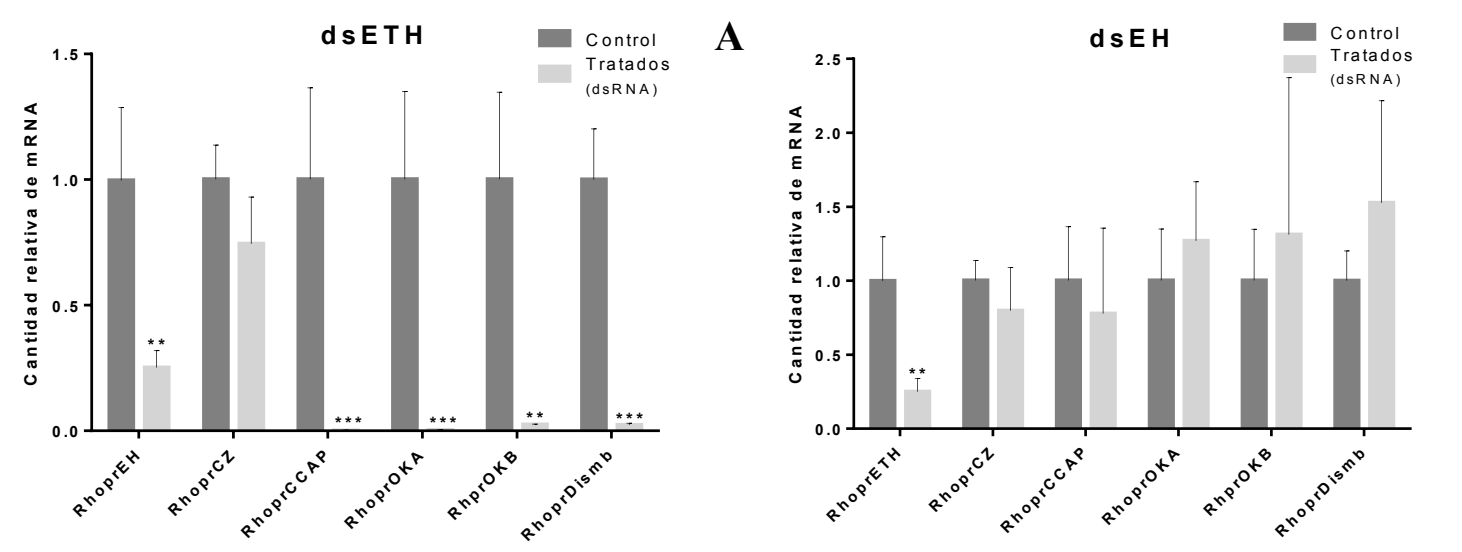

B

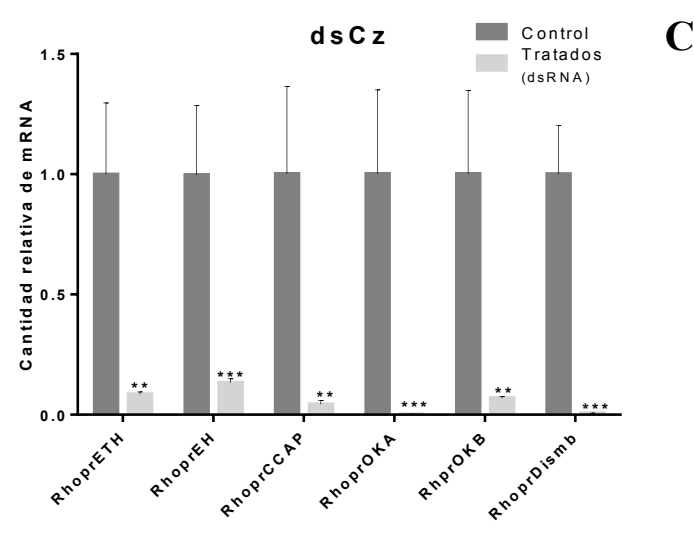

Figura 2.16: Expresión de neuropéptidos asociados a la muda, en ninfas de $4^{\text {to }}$ estadio 11 días PMB, en insectos silenciados para diferentes hormonas. (A) RhoprETH (B) RhoprEH (C) RhoprCZ. ANOVA de un factor; $*=\mathrm{p}<0,05 ; * *=\mathrm{p}<0,01 ; * * *=\mathrm{p}<0,001 ; \mathrm{n}=6)$.

Los resultados obtenidos fueron coincidentes tanto el día 6 como el día 11 PBM, con la única excepción de que dsCZ disminuyó significativamente la expresión de RhoprOKB sólo en el día 11 PBM $(\mathrm{p}<0,01 ; n=6)$.

El silenciamiento de RhoprETH tuvo el efecto de disminuir la expresión de: RhoprEH ( $\mathrm{p}<0,01$ tanto día 6 como 11 PBM); RhoprOKA ( $<<0,01$ día 6 y $\mathrm{p}<0,001$ día 11 PBM); RhoprOKB ( $\mathrm{p}<0,01$ tanto día 6 como 11 PBM); RhoprCCAP ( $<<0,01$ tanto día 6 como $11 \mathrm{PBM}$ ) y RhoprDis ( $<<0,01$ tanto día 6 como $11 \mathrm{PBM}$ ). No afectó sin embargo la expresión de RhoprCZ ninguno de los días analizados (n=6) (Fig. 2.15 A y Fig. $2.16 \mathrm{~A})$.

El silenciamiento de RhoprCZ tuvo como efecto la disminución de la expresión de: RhoprEH ( $p<0,001$ tanto día 6 como 11 PBM); RhoprOKA ( $p<0,01$ día 6 y $p<0,001$ día 11 PBM); RhoprOKB ( $<<0,01$ solamente día 11 PBM); RhoprCCAP ( $\mathrm{p}<0,01$ día 6 y $\mathrm{p}<0,05$ día 11 PBM) y RhoprDis ( $\mathrm{p}<0,01$ día 6 y $\mathrm{p}<0,001$ día $11 \mathrm{PBM})$. 
Por otro lado además, el patrón de expresión del receptor de RhoprCZ en $R$. prolixus coincide con el patrón de expresión de las orcokininas en $R$. prolixus en las células ventro mediales del cerebro, SOG, PTG, MTGM, en buche y las gónadas (Sterkel 2011; Hamoudi, Lange et al. 2016; Wulff, Sierra et al. 2017), lo que refuerza la hipótesis de una regulación hormonal de RhoprOKs por parte de RhoprCZ.

El silenciamiento de EH presentó efectos más puntuales, disminuyendo solo los niveles de expresión de ETH significativamente, tanto día $6(\mathrm{p}<0,01 ; \mathrm{n}=6)$, como día 11 PBM $(\mathrm{p}<0,01 ; \mathrm{n}=6)$. Por tanto, los resultados de expresión génica reflejan lo observado con el silenciamiento transcripcional, donde la baja en la expresión de EH provoca un retardo pero no un arresto de la muda, como sí sucede con el silenciamiento transcripcional de las hormonas RhoprETH y RhoprCZ. Los resultados sugieren hacia un papel crucial de estas dos últimas hormonas en la ecdisis, y un rol accesorio para RhoprEH.

Estos resultados, junto con lo descripto a continuación, nos permitieron proponer un posible modelo de trabajo acerca de la interrelación de los factores peptídicos reguladores de la ecdisis en $R$. prolixus (ver más abajo). Si bien nos resulta un modelo útil para el planteo de nuevas hipótesis experimentales, esperamos que trabajos futuros de nuestro grupo y otros, puedan confirmar o descartar las hipótesis aquí propuestas en base a los resultados obtenidos. De cualquier manera, hasta nuestro conocimiento, se trata del primer trabajo en estudiar de manera conjunta los principales factores reguladores de la ecdisis en un insecto no-holometábolo.

Los resultados confirman además, la conservación de los factores que regulan la muda en holometábolos: CZ, ETH, EH y CCAP, previamente observada en insectos holometábolos como D. melanogaster, M. sexta y T. castaneum (Zitnanova, Adams et al. 2001; Kim, Zitnan et al. 2006; Zitnan, Kim et al. 2007; Arakane, Li et al. 2008) (ver modelo propuesto de regulación endocrina de la ecdisis en $R$. prolixus, fig. 2.22).

Para determinar el correcto silenciamiento transcripcional, se midió la expresión de los transcriptos de RhoprETH, RhoprEH y RhoprCZ, tanto el día 6 como el día 11 PBM (ver anexo, testeo del silenciamiento transcripcional de los neuropéptidos ETH, EH, CZ: figs. 12 A y B). En todos los casos se confirmó el silenciamiento efectivo de cada gen. 


\subsubsection{Efecto de dsOKS sobre neuropéptidos relacionados con la regulación de la}

muda.

Una vez que probamos que la red peptidérgica de regulación de la ecdisis estaría conservada entre holometábolos y $R$. prolixus (apartado anterior), nos propusimos observar el efecto del silenciamiento de las OKs sobre la expresión de genes de esta red.

Se midió entonces el efecto del silenciamiento de RhoprOKs (inyectando 48hs previo a la ingesta), sobre los niveles de expresión (11 días PBM), de los principales neuropéptidos relacionados a la muda en insectos: ETH, EH, CZ y CCAP (Fig. 2.17).
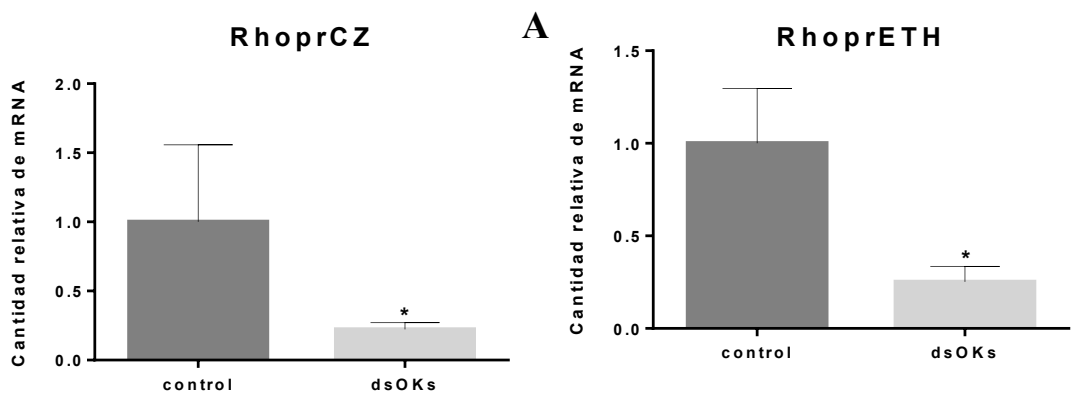

B
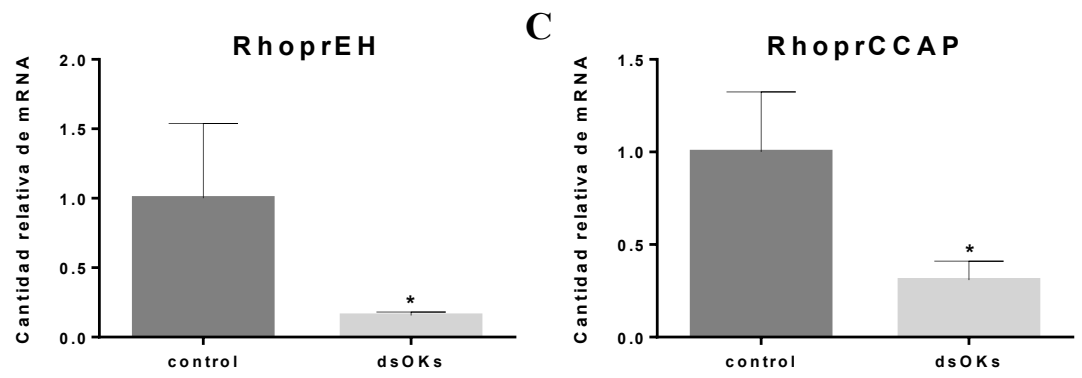

$\mathbf{D}$

Figura 2.17: Medición de la expresión a nivel de transcripto total en ninfas de $4{ }^{\text {to }}$ estadio 11 días PBM, en insectos silenciados (dsOKs) y no silenciados para el gen de Orcokinina. (A) RhoprCZ. (B) RhoprETH. (C) RhoprEH. (D) RhoprCCAP. ANOVA de un factor, diferencias estadísticamente significativas (* $=\mathrm{p}<0,05 ; \mathrm{n}=5)$.

Los resultados indican que el silenciamiento todo el precursor de la orcokinina (dsOKs), afecta negativamente la expresión de las hormonas RhoprETH, RhoprEH, RhoprCZ y RhoprCCAP, medido el día 11 PBM (Fig. 2.14 A-D). 
Consideramos que el efecto conjunto de RhoprOKA y RhoprOKB sobre la síntesis de 20E y expresión de RhoprCZ, podría provocar un efecto global sobre la red peptidérgica de la muda, y como consecuencia una disminución de todas las hormonas asociadas a la muda hacia final del ciclo. Previamente, en $M$. sexta, se reportó que la disminución en la concentración de 20E disminuye la expresión de ETH, durante los dos últimos estadios larvales (Zitnanova, Adams et al. 2001). Por otra parte, si bien la $\mathrm{CZ}$ aumenta la síntesis y liberación de $\mathrm{ETH}$, una concentración elevada en forma in vitro (10nM para M. sexta) provoca un arresto completo en la liberación de ETH a partir de las células Inka del último estadio larval (Kim, Spalovska-Valachova et al. 2004). Estos dos factores en conjunto podrían generar una disminución de todas las hormonas de la muda hacia final del ciclo, reguladas por ETH a través de su receptor ETHR-A (Kim, Zitnan et al. 2006; Kim, Zitnan et al. 2006; Zitnan, Kim et al. 2007). La expresión de $\mathrm{CZ}$ no se encuentra bajo la regulación de ETH, sin embargo en D. melanogaster se observó que un aumento en la concentración de 20E durante la metamorfosis de la pupa genera apoptosis en las neuronas que expresan $\mathrm{CZ}$ ubicadas en la cuerda nerviosa ventral (Choi, Lee et al. 2006; Lee, Sehgal et al. 2013). De acuerdo a nuestros resultados, la disminución de las OKs en $R$. prolixus produce un aumento en la cantidad de ecdisteroides. Un aumento por sobre el umbral normal en la concentración de ecdisteroides, como sucede con dsOKS (Fig. 2.12) podría provocar degeneración en las neuronas que expresan $\mathrm{CZ}$ y una consecuente disminución en la expresión de esta hormona.

\subsubsection{Efecto de dsOKA y dsOKB sobre neuropéptidos relacionados con la regulación de la muda}

Se estudió además el efecto de los transcriptos RhoprOKA y RhoprOKB por separado sobre la red peptidérgica reguladora de la muda.

Se midió la expresión de ETH, EH, CZ y CCAP en insectos silenciados para los transcriptos RhoprOKA o RhoprOKB. El primer experimento fue realizado con ninfas $4^{\text {to }}$ estadio 6 días PBM (Fig. 2.18) (pico de ecdisona; Fig. 2.12), y el segundo con insectos del mismo estadio pero sacrificados 11 días PBM (un día antes de la ecdisis) (Fig. 2.19). 

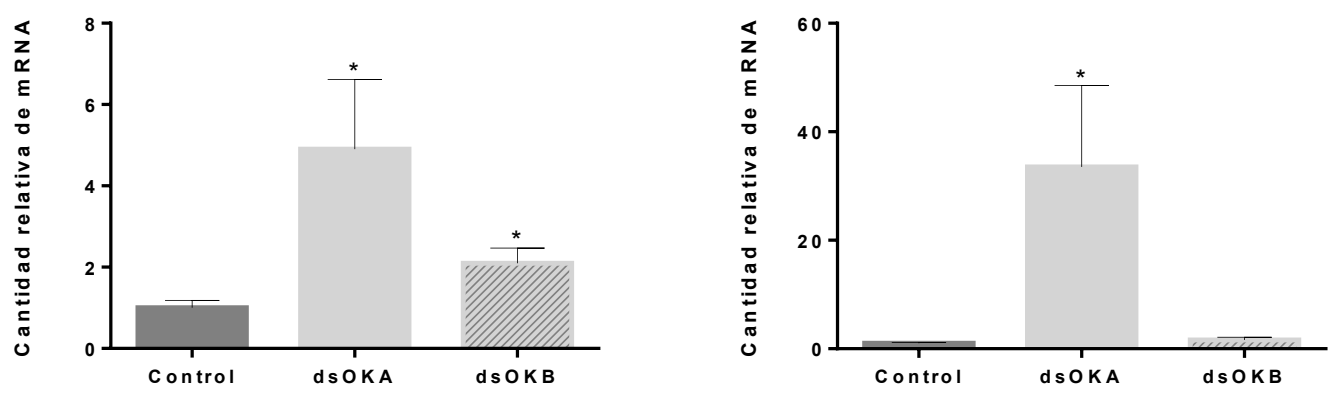

RhoprETH

C

RhoprEH

D
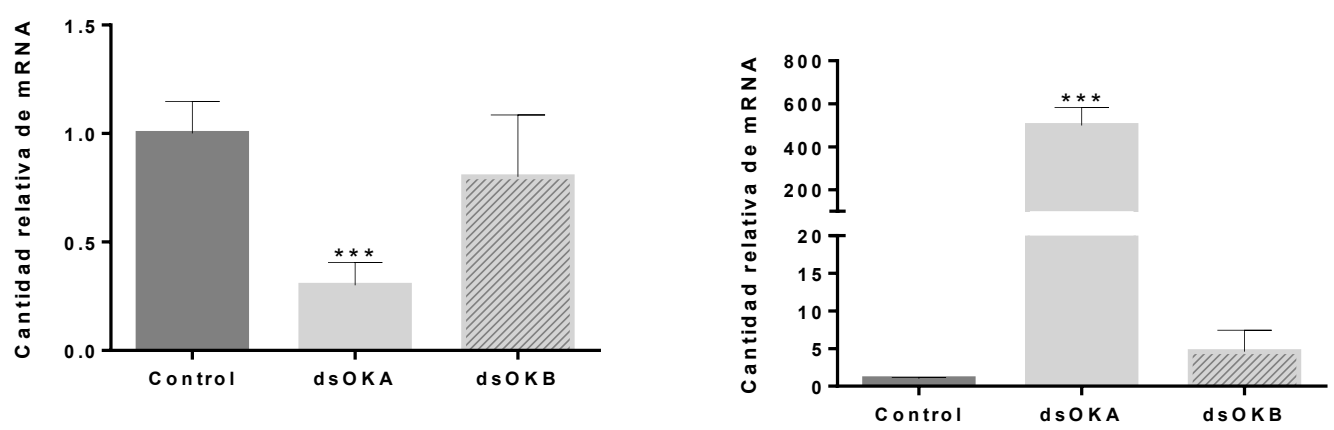

RhoprCZ

E
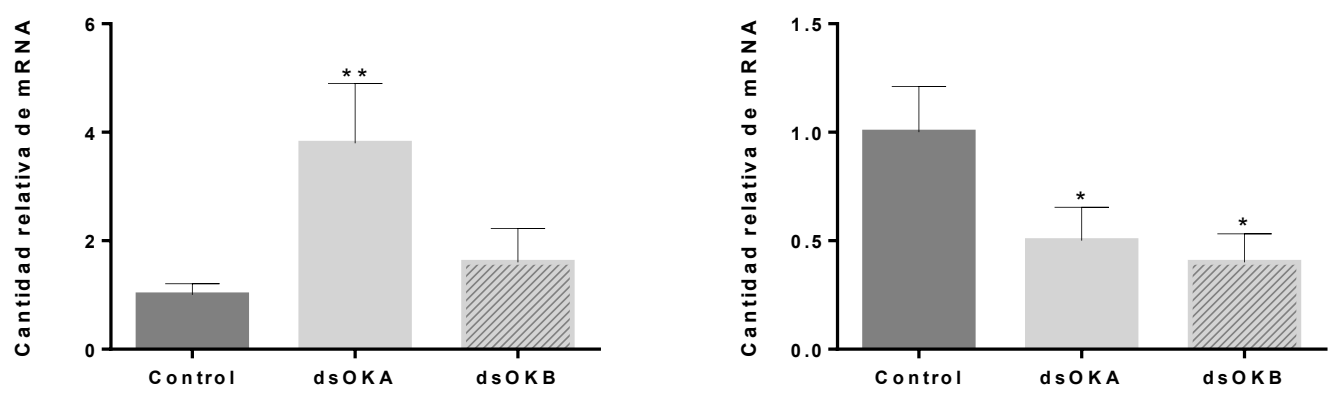

Figura 2.18: Expresión en ninfas de $4^{\text {to }}$ estadio 6 días PMB, en insectos silenciados para dsOKA, dsOKB) e insectos control. (A) RhoprE75. (B) RhoprDis. (C) RhoprETH. (D) RhoprEH. (E) RhoprCZ. (F) RhoprCCAP. ANOVA de 1 factor $(*=\mathrm{p}<0,05 ; * *=\mathrm{p}<0,01 ; * * *=\mathrm{p}<0,001 ; \mathrm{n}=5)$.

En insectos inyectados con dsOKA, se observó una disminución significativa de la expresión de los genes RhoprETH $(\mathrm{p}<0,001 ; \mathrm{n}=5)$ y RhoprCCAP $(\mathrm{p}<0,05 ; \mathrm{n}=5)$ el día 6 PBM (Figs. 2.18 C y F), al tiempo que un aumento significativo de RhoprEH $(\mathrm{p}<0,001 ; \mathrm{n}=5)$ y RhoprCZ $(\mathrm{p}<0,01 ; \mathrm{n}=5)$ (Figs. 2.18 D y E). Hasta el momento no 
podemos determinar si los resultados obtenidos se deben a una acción directa de RhoprOKA, o a un efecto indirecto, por ejemplo debido al aumento en los niveles de 20E. En ese sentido, en M. sexta se observó que se incrementa la transcripción de ETH en respuesta al aumento de 20E (Zitnanova, Adams et al. 2001). Por otro lado, en $D$. melanogaster, se observó aumenta la expresión de CCAP en respuesta a un aumento en la expresión de 20E (Kim, Zitnan et al. 2006; Di Cara and King-Jones 2013).

En sentido opuesto, si bien EH regula la síntesis y liberación de ETH, en $M$. sexta y Antheraea polyphemus se observó que EH es incapaz de estimular la síntesis de ETH a elevadas concentraciones de 20E, e incluso la síntesis de EH es reprimida a elevadas concentraciones de 20E (Schwartz and Truman 1982; Morton and Truman 1988; Zitnan, Kim et al. 2007). Por último, en D. melanogaster se observó que la 20E regula la apoptosis de las neuronas ipsilaterales del cerebro (Choi, Lee et al. 2006; Lee, Sehgal et al. 2013).

Estos resultados (Figs. 2.18 E y 2.19 E) se desarrollan en un sentido opuesto a lo observado al silenciar ambas isoformas juntas (Fig. 2.17 A). Dado el carácter ecdisteroidostático tanto de $\mathrm{OKA}$ como $\mathrm{OKB}$, es posible que sólo el silenciamiento conjunto de las OKs provoque un umbral suficiente en la concentración de ecdisteroides como para generar un efecto negativo sobre la síntesis de CZ. Futuros experimentos podrán determinar los mecanismos de modulación de RhoprOKA sobre otros genes reguladores de la ecdisis.

El silenciamiento de la isoforma RhoprOKB el día 6 PBM provocó sólo una disminución significativa del gen RhoprCCAP ( $<<0,05$; $n=5)$ (Fig. 2.18 F). El efecto más restringido de RhoprOKB respecto de RhoprOKA en la expresión de genes reguladores de la ecdisis se correlaciona con los fenotipos en cada caso asociados a la muda: la ausencia de OKA provoca arresto de ecdisis y de OKB sólo retraso en la ecdisis (ver más arriba).

Es interesante mencionar además, que la inmuno-marcación de RhoprOKB en el sistema nervioso central, presentada en el Capítulo 1, es coincidente con lo publicado para RhoprCCAP (Lee and Lange 2011), lo que podría indicar coexpresión de los genes en las mismas células. Para esto se plantea la necesidad futura del análisis de colocalización entre ambos péptidos. Esto resultaría coherente además con los resultados presentados de regulación de RhoprCCAP por parte de RhoprOKB. 
Para el gen RhoprDis se vio significativamente aumentada su expresión con el silenciamiento de RhoprOKA (Fig. 2.18 B), tal como ocurrió para ambas isoformas en simultaneo (ver más arriba) (Fig. 2.11 B). Sin embargo, no se observó sobre-expresión de este gen en ausencia de RhoprOKB. Lo anterior podría indicar que es RhoprOKA es el principal responsable del efecto ecdisteroidostático, o particularmente para este día del ciclo.

Receptorde 20Es (E75)

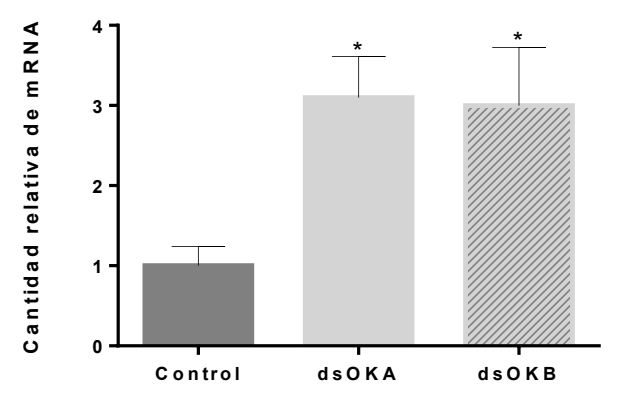

RhoprETH

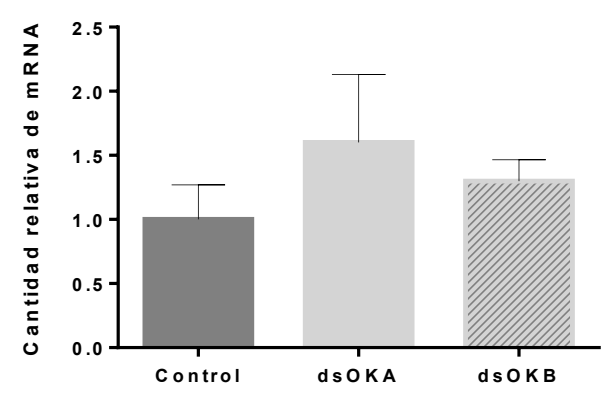

RhoprCz

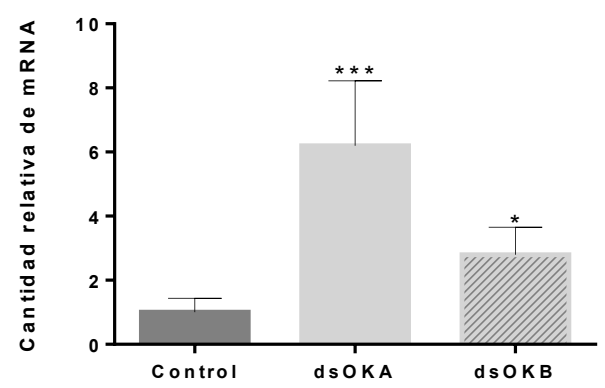

A

Dise m bodied

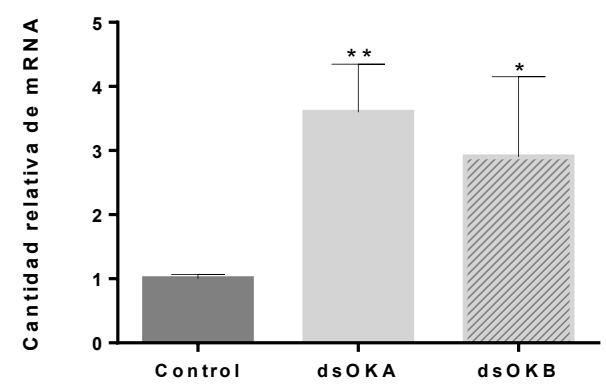

C

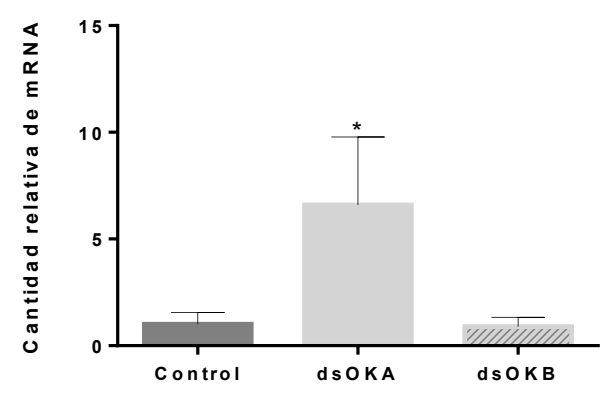

$\mathbf{E}$

RhoprCCAP

$\mathbf{F}$

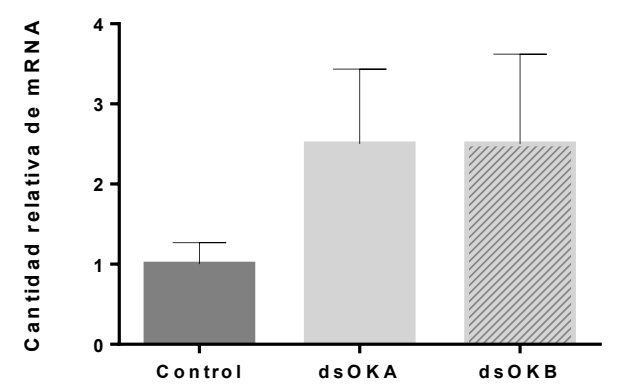

Figura 2.19: Expresión en ninfas de 4to estadio 11 días $\mathrm{PMB}$, en insectos silenciados para dsOKA, dsOKB) e insectos control. (A) RhoprE75. (B) RhoprDis. (C) RhoprETH. (D) RhoprEH. (E) RhoprCZ. (F) RhoprCCAP. ANOVA de 1 factor $(*=\mathrm{p}<0,05 ; * *=\mathrm{p}<0,01 ; * * *=\mathrm{p}<0,001, \mathrm{n}=5)$. 
En el día 11 PBM, al igual que en el día 6 PBM, observó un aumento significativo de RhoprCZ ante la disminución RhoprOKA (p<0,001; n=5) (Fig. 2.19 E). En este día además, bajo el tratamiento con dsOKB, se observó un incremento en la expresión del gen RhoprCZ $(\mathrm{p}<0,05 ; \mathrm{n}=5)$ (Fig. 2.19 E). Las diferencias podrían deberse a efectos facilitadores dependientes de la concentración de ecdisona tal como se discutió anteriormente. En el día 11 PBM (a diferencia del día 6 PBM) dsOKB aumentó la expresión de RhoprDis, lo cual sugeriría efecto ecdisteroidostático de OKB solo sobre final del ciclo de muda.

Al igual que en el día 6, en el día 11 PBM se observó un aumento significativo de RhoprEH con el silenciamiento de RhoprOKA ( $<<0,05$; $n=5$ ) (Fig. 2.19 D), lo cual sugiere que RhoprOKA tendría la capacidad de reprimir la expresión de RhoprEH tanto sobre mitad del ciclo de muda, como sobre el proceso de ecdisis. Sin embargo, el efecto de OKA sobre EH fue de mucha mayor magnitud el día 6 (500 veces) respecto del día 11 PBM (casi 7 veces). Esto podría sugerir que el efecto de OKA sobre esta hormona está incrementado por condiciones fisiológicas presentes durante el pico de ecdisteroides.

En el día 11 PBM, ni RhoprETH ni RhoprCCAP vieron modificada su expresión en insectos que expresaban niveles muy bajos de RhoprOKA ni RhoprOKB (Figs. 2.19 C y F).

Con el fin de confirmar el silenciamiento transcripcional, se midió la expresión de los transcriptos en cada caso, en los días en los cuales se realizaron los ensayos y se constató una baja significativa en la expresión con cada uno de los tratamientos (ver anexo, testeo del silenciamiento transcripcional del gen orcokinina, fig. 11 A-B).

\subsubsection{Ensayos in vitro para el estudio del papel de RhoprOKs en la red peptidérgica de regulación de la ecdisis}

Los resultados presentados más arriba demuestran que OKs es un factor con actividad ecdisteroidostática y forma parte de la red peptidérgica de regulación de la muda y ecdisis en insectos, al menos, en la especie utilizada aquí como modelo. 
Realizamos una aproximación in vitro con el fin de validar los resultados obtenidos con otra aproximación experimental. Mediante un preparado in vitro evaluamos el efecto de la adición al medio de péptidos OKA u OKB sintéticos sobre la expresión de genes relacionados a la muda (ETH, EH, CZ, CCAP).

El ensayo consistió en disecar las ninfas de $4^{\text {to }}$ estadio 11 días PBM, a fin de exponer el carcas conteniendo: sistema nervioso, cuerpo graso, epidermis y tráqueas, tejidos donde se expresan los péptidos a testear (ver detalle en Materiales y Métodos). Se mantuvo a los individuos bajo medio Grace de insectos (control), o bajo medio suplementado con: OKA u OKB sintéticos, o $20 \mathrm{E}$, todos a una concentración $10^{-6} \mathrm{M}$. Después de 3hs se conservaron los individuos separadamente en Trizol a fin de preparar ADNc para estudiar expresión de genes. El mismo ensayo se repitió en dos condiciones distintas: insectos sin tratar, o silenciados para el gen de RhoprOKs (inyectados con dsOKs, según lo descripto anteriormente). Además de medir la expresión de RhoprOKA y RhoprOKB, en ambos experimentos se evaluó la expresión de genes asociados a la regulación de la ecdisis en insectos mencionados más arriba.

En el experimento con insectos no silenciados para RhoprOKs, la adición de 20E al medio provocó una disminución significativa sólo en el nivel de expresión de CCAP $(\mathrm{p}<0,05 ; \mathrm{n}=6)$. El resto de las hormonas no variaron significativamente su expresión (Fig. 2.20 C). En los insectos silenciados para el gen RhoprOKs, la adición de 20E provocó un aumento de 2,9 veces en la expresión de RhoprOKA ( $<<0,05 ; n=6)$ (Fig. $2.21 \mathrm{C}$ ). Cabe recordar que el precursor de OKs, fue silenciado en un $82 \%$, con lo cual se considera que la respuesta en la síntesis de OKA en respuesta a la 20E se observó sobre el $18 \%$ restante de transcriptos sin silenciar.

El resto de los genes testeados presentaron una disminución significativa en sus niveles de expresión (ETH $p<0,001$; EH p $<0,001$; CZ $p<0,001$; CCAP $p<0,01$; OKB $\mathrm{p}<0,01 ; \mathrm{n}=6$ ) (Fig. $2.21 \mathrm{C}$ ). Los resultados presentados a continuación, sugieren que la disminución en la expresión de los genes mencionados, se correlaciona siempre con un aumento de RhoprOKA (Figs. 2.20 A y 2.21 A), tanto por agregarlo al medio como de manera indirecta cuando es provocado por la adición de 20E (Fig. 2.21 C).

Dadas las observaciones presentadas a lo largo del trabajo, sabemos que los insectos silenciados para RhoprOKs poseen concentraciones de ecdisona superiores a lo normal, durante el ciclo entre la ingesta y la ecdisis (Fig. 2.12). Los efectos de la 
ecdisona en la expresión génica son dependientes de factores de transcripción que actúan como posibilitadores (King-Jones, Charles et al.). Estos factores de transcripción a su vez modulan su expresión de acuerdo a la concentración de ecdisona (Talbot, Swyryd et al. 1993). Proponemos que estas condiciones pueden depender de la concentración de ecdisona, y de ahí la diferencia en los resultados observados en los experimentos realizados con insectos silenciados o no silenciados. Futuros ensayos servirán para confirmar o descartar las hipótesis abiertas.

Nuestros resultados globalmente sugieren hacia una retroalimentación negativa entre ecdisona y RhoprOKA, al menos en las condiciones fisiológicas descriptas y testeadas: 20E estimularía la transcripción de RhoprOKA, y a su vez la concentración de ecdisona es disminuida por este neuropéptido. Esto tendría a su tiempo efecto en la expresión de otros factores integrantes de la red de regulación de la ecdisis.

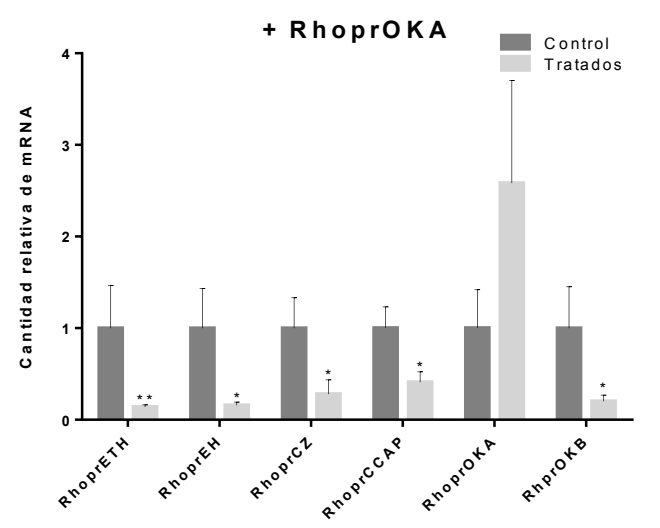

A
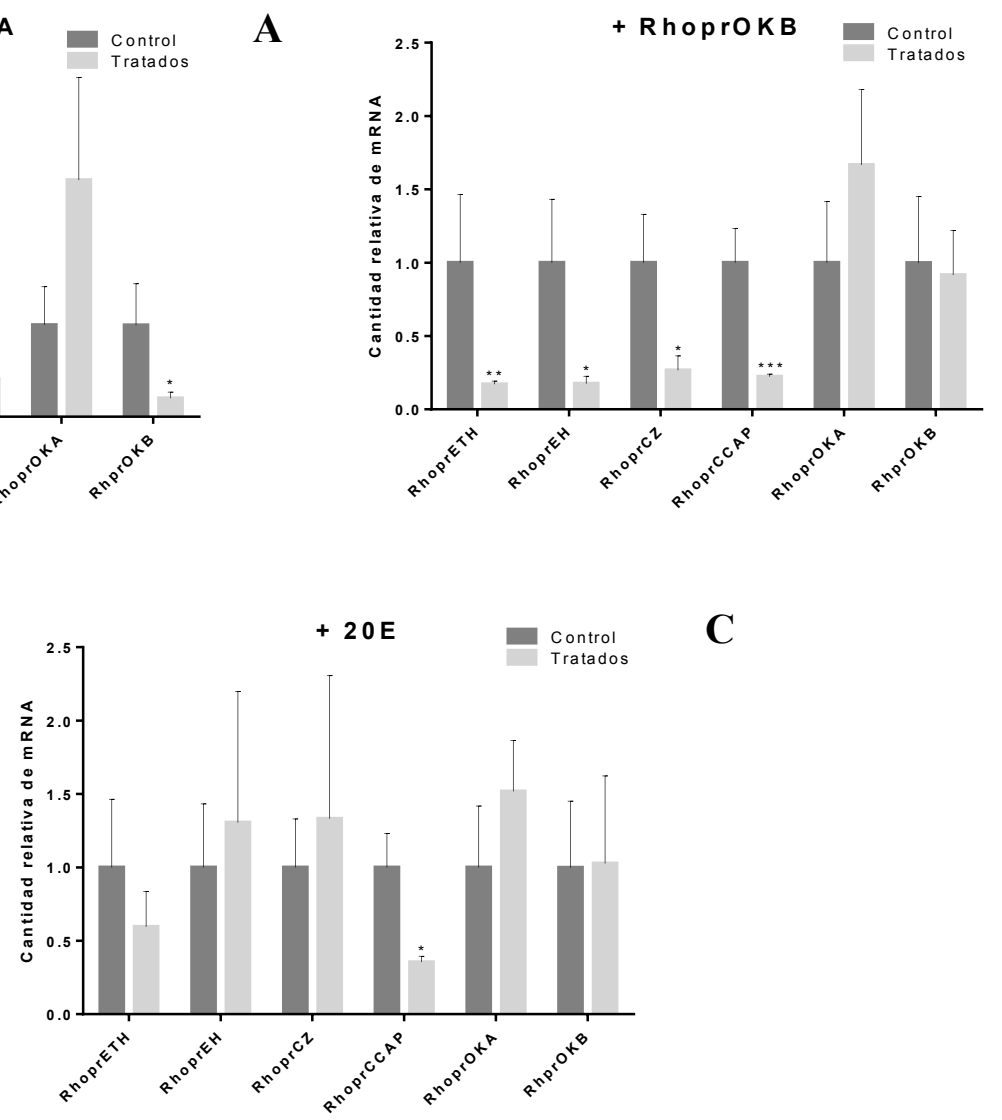

C

Figura 2.20: Medición de la expresión a nivel de transcripto total de neuropéptidos asociados a la muda, en ninfas de $4^{\text {to }}$ estadio 11 días PMB en insectos no silenciados para OKs, en respuesta a la aplicación exógena de RhoprOKA (péptido sintético), RhoprOKB (péptido sintético) y 20Es (A) Expresión de diferentes péptidos en respuesta a RhoprOKA (B) Expresión de diferentes péptidos en respuesta a RhoprOKB (C) Expresión de diferentes péptidos en respuesta a 20Es. ANOVA de un factor, diferencias estadísticamente significativas $(*=\mathrm{p}<0,05 ; * *=\mathrm{p}<0,01 ; * * *=\mathrm{p}<0,001 ; \mathrm{n}=6)$. 
RhoprCCAP es el único gen que disminuye su expresión en ambos ensayos con $20 \mathrm{E}$ (con y sin tratamiento con dsOKs). Esto podría deberse a una disminución en la expresión de ETH. El aumento en la concentración de ETH en hemolinfa desencadena un incremento en la transcripción y liberación de CCAP (Gammie and Truman 1999; Kim, Zitnan et al. 2006). Sin embargo, en el ensayo con insectos sin silenciar, ETH no disminuye significativamente, y baja su expresión en un 40\%. Un aumento o disminución en la expresión de ETH podría poseer un efecto amplificado sobre la expresión de CCAP, dado el extenso patrón de expresión de CCAP en R. prolixus, tanto dentro del SNC como en tejidos periféricos (Lee and Lange 2011). Por otro lado podría ser un efecto represivo específico de 20E sobre CCAP durante esta etapa tardía del ciclo de muda, para cual se plantean ensayos a futuro para determinar esta posible interacción.

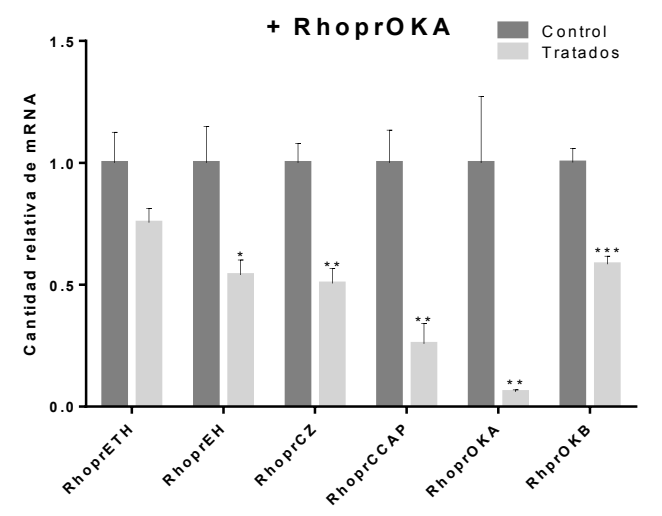

A

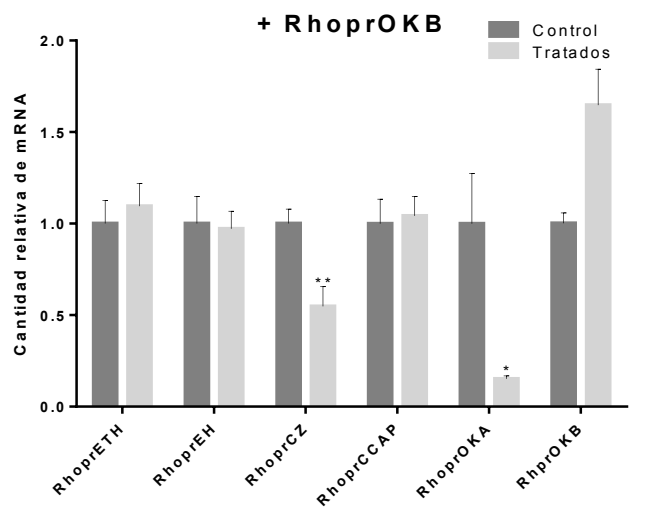

B

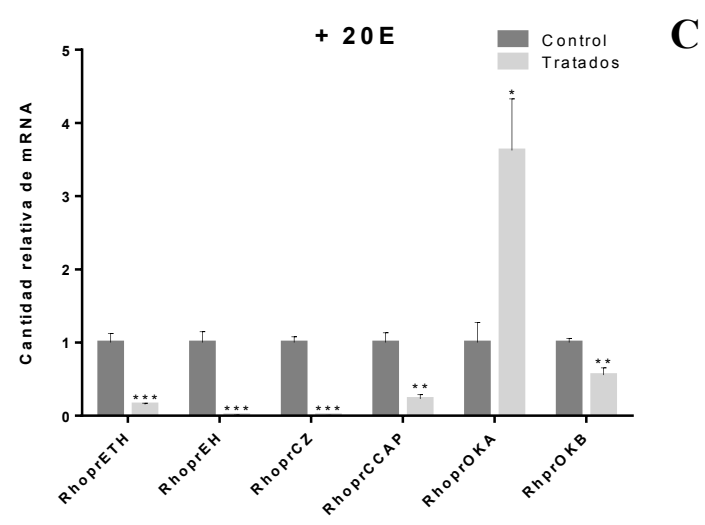

Figura 2.21: Medición de la expresión a nivel de transcripto total de neuropéptidos asociados a la muda, en ninfas de $4^{\text {to }}$ estadio 11 días PMB silenciadas para el gen de orcokinina (dsOKs), en respuesta a la aplicación exógena de RhoprOKA (péptido sintético), RhoprOKB (péptido sintético) y 20Es (A) Expresión de diferentes péptidos en respuesta a RhoprOKA (B) Expresión de diferentes péptidos en respuesta a RhoprOKB (C) Expresión de diferentes péptidos en respuesta a 20Es. ANOVA de un factor, diferencias estadísticamente significativas $(*=\mathrm{p}<0,05 ; * *=\mathrm{p}<0,01 ; * * *=\mathrm{p}<0,001 ; \mathrm{n}=6)$. 
Con respecto a la aplicación de los péptidos sintéticos, en el primer ensayo (insectos no silenciados para RhoprOKs), se observó una disminución en el nivel de expresión de RhoprETH ( $<<0,01)$, RhoprEH ( $<<0,01)$, RhoprCZ $(\mathrm{p}<0,01)$ y RhoprOKB $(\mathrm{p}<0,01)(\mathrm{n}=6)$ con la adición al medio de OKA sintético. Por el contrario, RhoprOKA aumentó su expresión (1,5 veces), aunque no de manera significativa (Fig. 2.20 A). Es interesante destacar que el mismo resultado en la regulación de los distintos genes se obtuvo para insectos silenciados para dsOKs suplementados in vitro con $20 \mathrm{E}$ (ver figura $2.21 \mathrm{C}$, más arriba). Nuevamente, los resultados sugieren hacia una interacción entre 20E y RhoprOKA, un campo abierto para futuros estudios.

En cuanto a RhoprOKB (en insectos no silenciados), su adición al medio provocó una disminución significativa en el nivel de expresión de RhoprETH $(\mathrm{p}<0,01)$, RhoprEH (p<0,05), RhoprCZ (p<0,05) y RhoprCCAP (p<0,001) (Fig. 2.20 B; n=6).

El mismo experimento fue repetido en insectos silenciados para el gen RhoprOKs. A diferencia del experimento con insectos no silenciados, la expresión de RhoprOKA en este caso disminuyó significativamente con la adición del péptido $(\mathrm{p}<0,01 ; \mathrm{n}=6)$. Por otro lado, RhoprETH, si bien bajó su expresión, no tuvo un descenso significativo (Fig. 2.21 A). El resto de las hormonas se comportó igual que en los insectos que expresaban OKs (descendieron significativamente en todos los casos).

Cabe destacar, que el efecto de silenciar RhoprOKA (aumentó la expresión de RhoprEH y RhoprCZ el día 11PBM), se revierte con la adición del péptido, lo que refuerza por otra técnica los resultados obtenidos por silenciamiento transcripcional previamente.

En insectos dsOKs, la adición al medio de $\mathrm{OKB}$, provocó una disminución significativa de RhoprCZ (Fig. 2.21 B). Estos resultados también resultan coherentes con lo obtenido con el silenciamiento transcripcional, puesto que la baja de expresión de RhoprOKB genera un aumento de RhoprCZ el día 11 PBM (Fig. 2.19 E). Además, se observa que dsOKs, RhoprOKB regula negativamente la expresión de RhoprOKA, lo que sugiere un tipo de interacción regulatoria entre ambas isoformas del gen.

Finalmente, en insectos dsOKs la adición de $20 \mathrm{E}$ provocó un aumento significativo en la expresión de RhoprOKA $(p<0,05 ; n=6)$. Sin embargo, cuando se inyectaron $10 \mu \mathrm{gs}$ de $20 \mathrm{E}$ in vivo en ninfas $4^{\text {ta }}$ ayunadas, no hubo cambios en la 
expresión de RhoprOKA ni RhoprOKB (ver arriba). Consideramos que la aproximación in vitro ofrece mayor control de las variables, y por tanto es una herramienta interesante para observar resultados que quedarían enmascarados con las aproximaciones in vivo.

El silenciamiento transcripcional de RhoprOKs fue confirmado mediante qRTPCR y se constataron niveles significativos de caída de transcripto para OKA mayor a $88 \%(\mathrm{p}<0,05 ; \mathrm{n}=4)$ y OKB mayor a $80 \%(\mathrm{p}<0,01 ; \mathrm{n}=4)$ (ver anexo, testeo del silenciamiento transcripcional del gen orcokinina, fig. $11 \mathrm{C}$ ).

\subsubsection{Red endócrina que regula el ciclo de muda en $\boldsymbol{R}$. prolixus}

Con los resultados expuestos a lo largo del trabajo, se buscó proponer un posible modelo de interacción de la red peptidérgica de regulación de la muda en $R$. prolixus. Se analizaron los perfiles de expresión de las hormonas a distintos tiempos PBM presentados más arriba. Además, mediante el índice de correlación de Pearson en las comparaciones de a pares, y los índices de Tau-B de Kendall y Spearman para muestras no paramétricas, se analizó el grado interacción entre los distintos genes estudiados (Tabla 5).

Tabla 5: Indice de correlación respecto de la expresion de diferentes péptidos en nifas de $R$. prolixus

\begin{tabular}{lccccc}
\hline Hormonas & Estadío & Correlación & n & & n \\
\hline CCAP/CZ & & Dia 6 PBM & & Día 11 PBM & \\
CCAP/OKA & 4 to & - & - & $0,92^{* *}$ & 11 \\
CCAP/OKB & 4 to & $0,98^{*}$ & 4 & $0,93^{* *}$ & 6 \\
CCAP/EH & 4 to & $0,98^{*}$ & 4 & $0,88^{* *}$ & 8 \\
ETH/EH & 4 to & $(-) 1^{* *} \&$ & - & $(+) 0,91^{*}$ & 6 \\
CZ/ETH & 4 to & $1^{* *}$ & 6 & $0,99^{*}$ & 5 \\
EH/OKA & 4 to & $0,99^{* *}$ & 6 & $0,93^{*}$ & 5 \\
EH/OKB & 4 to & $(-) 0,99^{* *}$ & 4 & - & - \\
\hline
\end{tabular}

$*=\mathrm{p}<0,05 ; * *=\mathrm{p}<0,01$ Índice de Pearson (ndice parametetrico); \&:** $=\mathrm{p}<0,01$ por los indices de

Tau_b de Kendall y Spearman (índices no parametricos).

Los resultados respecto de la interacción entre los péptidos $\mathrm{CZ}, \mathrm{ETH}, \mathrm{EH}$ y CCAP son coincidentes con las conclusiones de los distintos experimentos realizados, 
así como con observaciones en insectos holometábolos (Zitnanova, Adams et al. 2001; Kim, Zitnan et al. 2006; Zitnan, Kim et al. 2007; Arakane, Li et al. 2008).

Se observa correlación positiva significativa entre ambas isoformas de orcokinina y el péptido CCAP, lo cual coincide con lo observado en el ensayo de silenciamiento transcripcional de RhoprOKA y RhoprOKB día 6 PBM (Fig. 2.18 F). Se confirmó además, una correlación negativa altamente significativa entre RhoprOKA y el péptido $\mathrm{EH}$, observado tanto en los ensayos de silenciamiento transcripcional como adición de RhoprOKA in vitro (Figs. 2.18 D, 2.19 D, 2.20 A y 2.21 A).

Es interesante destacar además la variación en la interacción entre los péptidos EH y CCAP. Se observa una correlación significativa entre ambos péptidos, pero de signo negativo para el día 6 PBM y positivo para el día 11 PBM (Tabla 5). Esto podría deberse a que el día 6 PBM ambos péptidos responden en forma antagónica a la elevada concentración de 20E: 20E incrementa la expresión de CCAP y disminuye la de EH (Gammie and Truman 1999; Di Cara and King-Jones 2013). Sin embargo, en el día 11 PBM la concentración hemocélica de 20E disminuye y se libera ETH para iniciar la última etapa del ciclo de muda (Zitnan, Kim et al. 2007). En M. sexta se observó que la aplicación in vitro de EH produce una serie de efectos: acumulación de GMPc en las neuronas ventro mediales pertenecientes a las red 27/704 que expresan CCAP; disminución en el tiempo de respuesta para esta red neuronal en comparación con la aplicación de ETH; el tiempo de respuesta en conjunto con CCAP fue significativamente menor que para CCAP en forma aislada. En base a estas observaciones se plantea que en $M$. sexta EH constituye un nexo entre ETH y CCAP aislada (Gammie and Truman 1999). Una interacción de este tipo podría explicar la correlación positiva observada entre EH y CCAP en nuestros resultados día 11 PBM.

Finalmente, se observó correlación positiva entre los transcriptos RhoprEH y RhoprOKB para los días 6 y 11 PBM. La hormona EH se expresa únicamente en las células ventromediales ubicadas en la margen posterior del cerebro (Kono, Nagasawa et al. 1990; Zitnan, Hollar et al. 2002; Kim, Zitnan et al. 2006; Zitnan, Kim et al. 2007). En $M$. sexta y D. melanogaster, se observó además la expresión del receptor de ETHRA en estas neuronas (Kim, Zitnan et al. 2006; Kim, Zitnan et al. 2006).

En el Capítulo 1 presentamos resultados de inmuno marcación positiva para RhoprOKB en células ubicadas en el margen medio posterior del cerebro, donde se 
ubican las células ventromediales en insectos holometábolos (ver resultados Capítulo 1). En este sentido, existe la posibilidad que estas neuronas en respuesta a RhoprETH coexpresen RhoprEH y RhoprOKB. Esto coincide con lo observado en los ensayos de silenciamiento transcripcional de RhoprETH (dsETH). Para el día 6 y día 11 PBM dsETH provocó una disminución altamente significativa de RhoprEH y RhoprOKs (Figs. 2.15A y 2.16A).

Futuros ensayos, nos permitirán determinar si EH y OKB se expresan en forma conjunta frente al estímulo de ETH, o indirectamente regulados por otros procesos neuroendocrinos.

El análisis global de los resultados y de la bibliografía, nos permitió proponer un modelo de regulación peptidérgica de la muda en $R$. prolixus (ver abajo, fig. 2.22). Es el primer modelo de este tipo propuesto para insectos hemimetábolos, y se basa en los resultados conjuntos de esta Tesis y los antecedentes bibliográficos para especies holometábolas.

Si bien para este trabajo se tomaron dos puntos temporales importantes del ciclo de muda (días 6 y 11 PBM), los cambios con toda certeza suceden en forma continua en el tiempo, lo que se infiere además de los perfiles hormonales, y todos los procesos fisiológicos. 


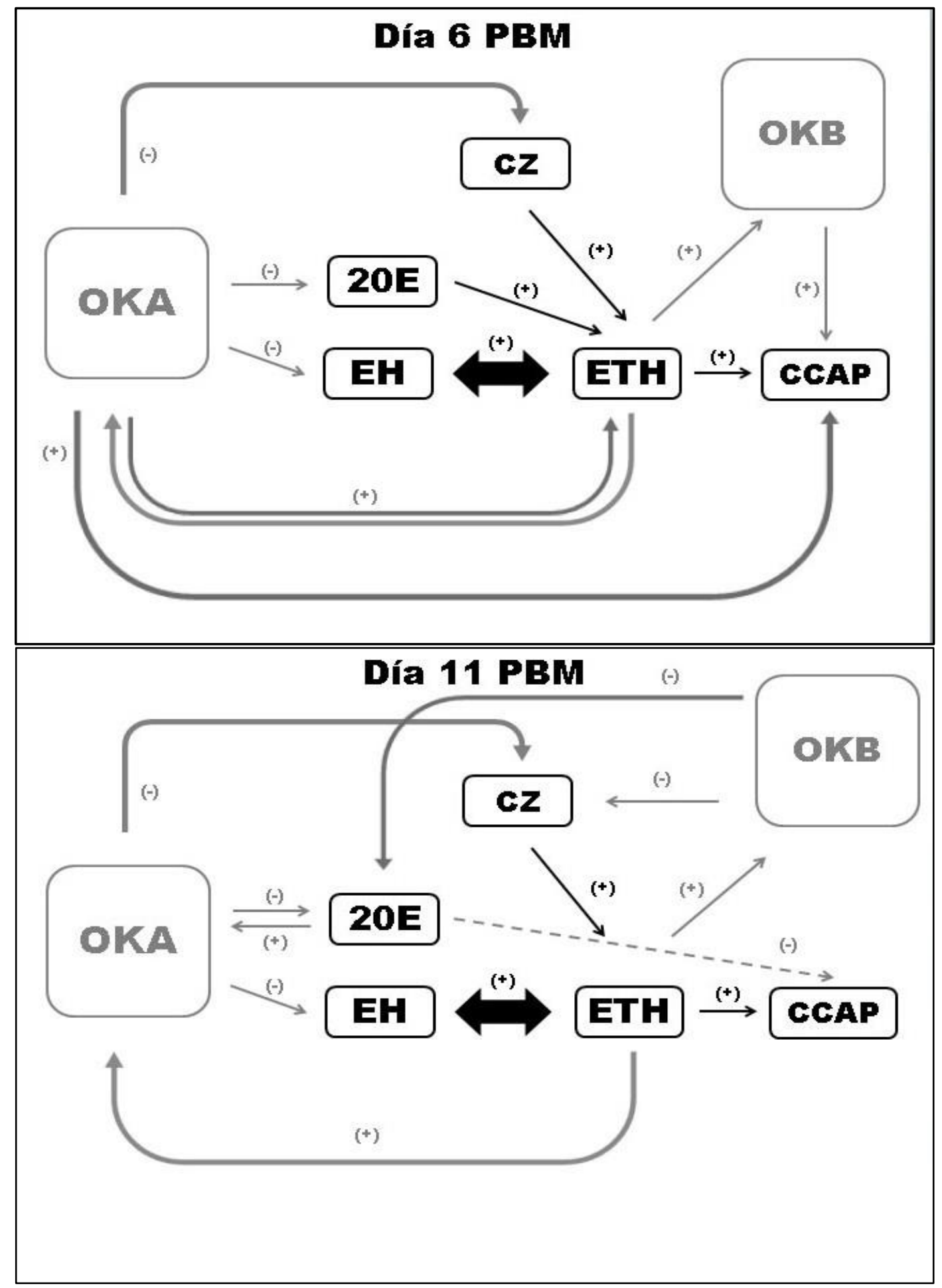

Figura 2.22: Modelo de regulación endócrina de la muda de $R$. prolixus, en ninfas de $4^{\text {to }}$ estadio días 6 y 11 PMB. En negro se confirma para un hemimetábolo, la vía de regulación endócrina previamente reportada en insectos holometábolos (Kim, Zitnan et al. 2006; Kim, Zitnan et al. 2006; Zitnan, Kim et al. 2007; Arakane, Li et al. 2008). En gris se hace referencia a la nueva vía de regulación endocrina de la muda descubierta en el insecto hemimetábolo $R$. prolixus. 


\subsection{CONCLUSIONES}

En el presente Capítulo:

* El gen RhoprOK incrementa su expresión en respuesta a la ingesta. Además, se encuentra funcionalmente asociado al ciclo de muda y ecdisis de $R$. prolixus.

* En R. prolixus, la concentración hemocélica de ecdisteroides varía en respuesta a la ingesta y esta variación se relaciona con el proceso de muda y ecdisis (coincidente con lo reportado para insectos holometábolos).

* En ausencia de expresión del gen RhoprOK, se incrementa la síntesis de ecdisteroides, sugiriendo un rol ecdisteroidostático para este gen.

* El gen RhoprOK, dentro del periodo comprendido entre la ingesta y la ecdisis, posee un patrón de interacción con los péptidos: RhoprCZ, RhoprETH, RhoprEH y RhoprCCAP, diferencial a nivel de isoformas.

* La 20E estimula la expresión de RhoprOKA, sugiriendo que su receptor (EcR) pudiese actuar como un factor de transcripción de OKA.

* De acuerdo con el perfil de expresión, el efecto del silenciamiento de cada péptido sobre los demás y las alteraciones en el proceso de ecdisis, se concluye que:

Los péptidos CZ, ETH, EH y CCAP forman parte de la regulación del ciclo de muda y la ecdisis de $R$. prolixus.

La orcokinina forma parte de esta red peptidérgica, que regula dichos procesos. 


\section{CONCLUSIONES GENERALES}

En la presente Tesis:

Existe una tercera isoforma para el gen precursor de OKs en insectos.

* El gen RhoprOK poseen un patrón de expresión asociado a cada isoforma.

De acuerdo al patrón de expresión del gen RhoprOK, y los antecedentes previos, se plantea la posibilidad que este gen este asociado funcionalmente a procesos tales como:

$>$ Regulación de ritmos circadianos.

$>$ Ingesta de alimento.

$>$ Ovogénesis y reproducción.

$>$ Ecdisis.

$>$ Síntesis de ecdisteroides.

El gen RhoprOK incrementa su expresión en respuesta a la ingesta. Además, se encuentra funcionalmente asociado al ciclo de muda y ecdisis de $R$. prolixus.

En $R$. prolixus, la concentración hemocélica de ecdisteroides varía en respuesta a la ingesta y esta variación se relaciona con el proceso de muda y ecdisis (coincidente con lo reportado para insectos holometábolos).

* En ausencia de expresión del gen RhoprOK, se incrementa la síntesis de ecdisteroides, sugiriendo un rol ecdisteroidostático para este gen.

El gen RhoprOK, dentro del periodo comprendido entre la ingesta y la ecdisis, posee un patrón de interacción con los péptidos: RhoprCZ, RhoprETH, RhoprEH y RhoprCCAP, diferencial a nivel de isoformas. 
La 20E estimula la expresión de RhoprOKA, sugiriendo que su receptor (EcR) pudiese actuar como un factor de transcripción de OKA.

De acuerdo con el perfil de expresión, el efecto del silenciamiento de cada péptido sobre los demás y las alteraciones en el proceso de ecdisis, se concluye que:

Los péptidos $\mathrm{CZ}$, ETH, EH y CCAP forman parte de la regulación del ciclo de muda y la ecdisis de $R$. prolixus.

La orcokinina forma parte de esta red peptidérgica, que regula dichos procesos. 


\section{ABREVIATURAS}

20E 20-Hidroxiecdisona

ABNs: Nervios Abdominales

ACN: Acetonitrilo

ACP: Peptido simil-AKH/CZ

AKH: Hormona Adipokinética

AN: Nervios que inervan las antenas

AVPL: Péptido simil-Arginina-Vasopresina

BSA: Albúmina serica bovina

Bztc: benzethonium cloride

CA: Corpora Allata

$\mathrm{CC}$ : Corpora Cardíaca

CCAP: Péptido Cardioacelerador de Crustáceos

CREG-UNLP: Centro Regional de Estudios Genómicos-Universidad Nacional de La Plata

ADNc: Acido desoxirribonucleico complementario

CZ: Corazonina

DH3 1: Hormona diurética simil- Calcitonina

DH44: Hormona diurética simil-CRF

dsDNA: Acido desoxirribonucleico doble hebra (del inglés: double stranded

Deoxyribonucleic Acid)

ARNdc: Ácido ribonucleico doble hebra (del inglés: double stranded Ribonucleic Acid)

EH: Hormona de Eclosión

ESI: Ionización por electrospray (Electrospray ionization)

ESTs: Expressed sequence tags

ETH: Hormona Disparadora de la Ecdisis

FA: Ácido fórmico

FaRPs: Superfamilia de péptidos RF-amida

FG: Ganglio frontal

GPCR: Receptores de membrana acoplados a proteína $\mathrm{G}$

GPN: Genes que codifican neuropéptidos

HCG: Ganglio hipocerebral

IHQ: Inmunohistoquímica 
ILPs: Péptidos simil-insulina

ITP: Péptido Transportador de Iones

$\mathrm{JH}$ : hormonas juveniles

LC: Cromatografía líquida

LNF: Neuropéptido F largo

$[\mathrm{M}+\mathrm{H}]$ : Masa monoisotópica protonada

MALDI: Matrix-assisted laser desorption/ionization

MFrN: Nervio frontal medio

MTGM: Ganglio Mesometatoraraxico

MS: Espectrometría de masas

MS/MS: Espectrometría de masas en tándem

MsN: Nervios metatoráxicos

MSP: Miosupresina

NCC: Proyecciones nerviosas que inervan la Corpora Cardíaca

NGS: Suero normal de cabra

OcN: Nervios ocelares

ORF: Marco de lectura abierto

PBM: Post alimentation (del inglés Post blood Meal)

PBS: Buffer fosfato PH 7,4

PTG: Ganglio protaráxico

PI: Pars intercerebralis

PL: Pars lateralis

PTM: Modificaciones post-traduccionales

RACE-PCR: Rapid amplification of cDNA ends

REL: Retículo Endoplasmático Liso

RER: Retículo Endoplasmático Rugoso

$\mathrm{RN}$ : Nervio recurrente

RNAss: Ácido ribonucleico simple hebra (del inglés: Ribonucleic Acid simple strand)

RPLC: Cromatografía líquida de fase reversa

SK: Sulfakininas

SOG: Ganglio Subesofágico

SN: Sistema Nervioso

SNC: Sistema Nervioso Central

SNF: Neuropéptido F corto 
SNP: Sistema Nervioso Periférico

SNS: Sistema Nervioso Estomatogástrico

TFA: Ácido trifluoroacético

TM: Túbulos de Malphigi

TN: Nervio tegumentario

UTR: Regiones no traducidas 


\section{BIBLIOGRAFÍA}

Adamo, S. A. (2004). "Estimating disease resistance in insects: phenoloxidase and lysozyme-like activity and disease resistance in the cricket Gryllus texensis." I Insect Physiol 50(2-3): 209-216.

Adams, M. D., S. E. Celniker, et al. (2000). "The genome sequence of Drosophila melanogaster." Science 287(5461): 2185-2195.

Adams, M. E. and D. Zitnan (1997). "Identification of ecdysis-triggering hormone in the silkworm Bombyx mori." Biochem Biophys Res Commun 230(1): 188-191.

Adelman, Z. N., C. D. Blair, et al. (2001). "Sindbis virus-induced silencing of dengue viruses in mosquitoes." Insect Mol Biol 10(3): 265-273.

Akai, H. (1971). "Ultrastructure of fibroin in the silk gland of larval Bombyx mori." Exp Cell Res 69(1): 219-223.

Akai, H., K. Kiguchi, et al. (1971). "Increased Accumulation of Silk Protein Accompanying JHInduced Prolongation of Larval Life in Bombyx mori L.(Lepidoptera : Bombycidae)." Applied Entomology and Zoology 6(4): 218-220.

Al Naggar, Y., G. Codling, et al. (2015). "Organophosphorus insecticides in honey, pollen and bees (Apis mellifera L.) and their potential hazard to bee colonies in Egypt." Ecotoxicol Environ Saf 114: 1-8.

Altstein, M. and D. R. Nassel (2010). "Neuropeptide signaling in insects." Adv Exp Med Biol 692: 155-165.

Ampleford, E. J. and C. G. H. Steel (1982). "The behaviour of Rhodnius prolixus (Stål) during the imaginal ecdysis." Can J Zool 60(2): 168-174.

Andersen, C. L., J. L. Jensen, et al. (2004). "Normalization of Real-Time Quantitative Reverse Transcription-PCR Data: A Model-Based Variance Estimation Approach to Identify Genes Suited for Normalization, Applied to Bladder and Colon Cancer Data Sets." Cancer Res 64(15): 5245.

Arakane, Y., B. Li, et al. (2008). "Functional analysis of four neuropeptides, EH, ETH, CCAP and bursicon, and their receptors in adult ecdysis behavior of the red flour beetle, Tribolium castaneum." Mech Dev 125(11-12): 984-995.

Araujo, R. N., A. Santos, et al. (2006). "RNA interference of the salivary gland nitrophorin 2 in the triatomine bug Rhodnius prolixus (Hemiptera: Reduviidae) by dsRNA ingestion or injection." Insect Biochem Mol Biol 36(9): 683-693.

Armitage, P. y. B. G. (1992). Estadística para la investigación Biomédica. Barcelona, DOYMA S.A.

Audsley, N. and R. E. Down (2015). "G protein coupled receptors as targets for next generation pesticides." Insect Biochem Mol Biol 67: 27-37.

Baker, J. D. and J. W. Truman (2002). "Mutations in the Drosophila glycoprotein hormone receptor, rickets, eliminate neuropeptide-induced tanning and selectively block a stereotyped behavioral program." J Exp Biol 205(Pt 17): 2555-2565.

Balabanidou, V., A. Kampouraki, et al. (2016). "Cytochrome P450 associated with insecticide resistance catalyzes cuticular hydrocarbon production in Anopheles gambiae." Proc Natl Acad Sci U S A 113(33): 9268-9273.

Balshin, M. and J. E. Phillips (1971). "Active absorption of amino-acids in the rectum of the desert locust (Schistocerca gregaria)." Nat New Biol 233(36): 53-55.

Belles, X. (2011). Origin and Evolution of Insect Metamorphosis, John Wiley \& Sons.

Berezikov, E. (2011). "Evolution of microRNA diversity and regulation in animals." Nat Rev Genet 12(12): 846-860.

Berge, J. B., R. Feyereisen, et al. (1998). "Cytochrome P450 monooxygenases and insecticide resistance in insects." Philos Trans R Soc Lond B Biol Sci 353(1376): 1701-1705. 
Bhatt, G., R. da Silva, et al. (2014). "The molecular characterization of the kinin transcript and the physiological effects of kinins in the blood-gorging insect, Rhodnius prolixus." Peptides 53: 148-158.

Bialecki, M., A. Shilton, et al. (2002). "Loss of the ecdysteroid-inducible E75A orphan nuclear receptor uncouples molting from metamorphosis in Drosophila." Dev Cell 3(2): 209220.

Bian, G., S. W. Shin, et al. (2005). "Transgenic alteration of Toll immune pathway in the female mosquito Aedes aegypti." Proc Natl Acad Sci U S A 102(38): 13568-13573.

Bockaert, J. and J. P. Pin (1999). "Molecular tinkering of G protein-coupled receptors: an evolutionary success." EMBO J 18(7): 1723-1729.

Boyer, S., H. Zhang, et al. (2012). "A review of control methods and resistance mechanisms in stored-product insects." Bull Entomol Res 102(2): 213-229.

Brooke, B. D. (2008). "kdr: can a single mutation produce an entire insecticide resistance phenotype?" Trans R Soc Trop Med Hyg 102(6): 524-525.

Brown, A. W. (1958). "The insecticide-resistance problem: a review of developments in 1956 and 1957." Bull World Health Organ 18(3): 309-321.

Brown, A. W. (1958). "Insecticide resistance in arthropods." Monogr Ser World Health Organ 38: 1-240.

Brown, A. W. (1969). "Insecticide resistance and the future control of insects." Can Med Assoc J 100(4): 216-221.

Brown, A. W. (1986). "Insecticide resistance in mosquitoes: a pragmatic review." J Am Mosq Control Assoc 2(2): 123-140.

Brown, A. W. and R. Pal (1971). "Insecticide resistance in arthropods." Public Health Pap 38(0): 1-491.

Brusca, R. C. a. G. J. B. (1990). Invertebrates. Sunderland, Massachusetts, Sinauer Associates

Bungart, D., H. Dircksen, et al. (1994). "Quantitative determination and distribution of the myotropic neuropeptide orcokinin in the nervous system of astacidean crustaceans." Peptides 15(3): 393-400.

Bungart, D., G. Kegel, et al. (1995). "Structure-activity relationships of the crustacean myotropic neuropeptide orcokinin." Peptides 16(2): 199-204.

Burand, J. P. and W. B. Hunter (2013). "RNAi: future in insect management." J Invertebr Pathol 112 Suppl: S68-74.

Caers, J., K. Boonen, et al. (2015). "Peptidomics of Neuropeptidergic Tissues of the Tsetse Fly Glossina morsitans morsitans." J Am Soc Mass Spectrom 26(12): 2024-2038.

Calderon-Fernandez, G. M., J. R. Girotti, et al. (2012). "Cuticular hydrocarbon pattern as a chemotaxonomy marker to assess intraspecific variability in Triatoma infestans, a major vector of Chagas' disease." Med Vet Entomol 26(2): 201-209.

Calderon-Fernandez, G. M., D. E. Moriconi, et al. (2017). "Transcriptome Analysis of the Triatoma infestans (Hemiptera: Reduviidae) Integument." J Med Entomol 54(6): 15311542.

Capriotti, N., G. Mougabure-Cueto, et al. (2014). "L925I mutation in the Para-type sodium channel is associated with pyrethroid resistance in Triatoma infestans from the Gran Chaco region." PLoS Negl Trop Dis 8(1): e2659.

Carvajal, G., M. I. Picollo, et al. (2014). "Is imidacloprid an effective alternative for controlling pyrethroid-resistant populations of Triatoma infestans (Hemiptera: Reduviidae) in the Gran Chaco ecoregion?" Mem Inst Oswaldo Cruz 109(6): 761-766.

Casida, J. E. (2009). "Pest toxicology: the primary mechanisms of pesticide action." Chem Res Toxicol 22(4): 609-619.

Casida, J. E. and K. A. Durkin (2013). "Neuroactive insecticides: targets, selectivity, resistance, and secondary effects." Annu Rev Entomol 58: 99-117. 
Cirimotich, C. M., J. C. Scott, et al. (2009). "Suppression of RNA interference increases alphavirus replication and virus-associated mortality in Aedes aegypti mosquitoes." BMC Microbiol 9: 49.

Clemons, A., M. Haugen, et al. (2011). "siRNA-mediated gene targeting in Aedes aegypti embryos reveals that frazzled regulates vector mosquito CNS development." PLoS One 6(1): e16730.

Clynen, E., J. Huybrechts, et al. (2006). "Annotation of novel neuropeptide precursors in the migratory locust based on transcript screening of a public EST database and mass spectrometry." BMC Genomics 7: 201.

Coast, G. M. and D. A. Schooley (2011). "Toward a consensus nomenclature for insect neuropeptides and peptide hormones." Peptides 32(3): 620-631.

Codling, G., Y. A. Naggar, et al. (2017). "Neonicotinoid insecticides in pollen, honey and adult bees in colonies of the European honey bee (Apis mellifera L.) in Egypt." Ecotoxicology.

Colborn, T. (2004). "Endocrine disruption overview: are males at risk?" Adv Exp Med Biol 545: $189-201$.

Colborn, T. (2004). "Neurodevelopment and endocrine disruption." Environ Health Perspect 112(9): 944-949.

Colborn, T., F. S. vom Saal, et al. (1993). "Developmental effects of endocrine-disrupting chemicals in wildlife and humans." Environ Health Perspect 101(5): 378-384.

Cottrell, C. B. (1962). "Imaginal Ecdysis Of Blowflies - Control Of Cuticuar Hardening And Darkening." Journal Of Experimental Biology 39: 395-411.

Cottrell, C. B. (1962). "Imaginal Ecdysis Of Blowflies - Evidence For A Change In Mechanical Properties Of Cuticle At Expansion." Journal Of Experimental Biology 39: 449-458.

Cottrell, C. B. (1962). "Imaginal Ecdysis Of Blowflies - Observations On Hydrostatic Mechanisms Involved In Digging And Expansion." Journal Of Experimental Biology 39: 431-448.

Coura, J. R. (2000). "The Oswaldo Cruz Institute and its importance in the Brazilian society. Perspectives for the 21st century." Mem Inst Oswaldo Cruz 95 Suppl 1: 9-16.

Coura, J. R., P. A. Vinas, et al. (2014). "Ecoepidemiology, short history and control of Chagas disease in the endemic countries and the new challenge for non-endemic countries." Mem Inst Oswaldo Cruz 109(7): 856-862.

Cullen, B. R. (2011). "Herpesvirus microRNAs: phenotypes and functions." Curr Opin Virol 1(3): 211-215.

Cullen, B. R. (2011). "Viruses and microRNAs: RISCy interactions with serious consequences." Genes Dev 25(18): 1881-1894.

Cuzin-Roudy, J., C. Strambi, et al. (1989). "Hemolymph ecdysteroids and molt cycle in males and females of Siriella armata M-Edw. (Crustacea: Mysidacea): possible control by the MI-ME X-organ of the eyestalk." Gen Comp Endocrinol 74(1): 96-109.

Chang, E. S. (1993). "Comparative endocrinology of molting and reproduction: insects and crustaceans." Annu Rev Entomol 38: 161-180.

Chang, J. C., R. B. Yang, et al. (2009). "Receptor guanylyl cyclases in Inka cells targeted by eclosion hormone." Proc Natl Acad Sci U S A 106(32): 13371-13376.

Chen, J., M. S. Choi, et al. (2015). "Isoform-specific expression of the neuropeptide orcokinin in Drosophila melanogaster." Peptides 68: 50-57.

Cheung, C. C., P. K. Loi, et al. (1992). "Primary structure of a cardioactive neuropeptide from the tobacco hawkmoth, Manduca sexta." FEBS Lett 313(2): 165-168.

Choi, Y.-J., G. Lee, et al. (2006). "Programmed cell death mechanisms of identifiable peptidergic neurons in \&lt;em\&gt;Drosophila melanogaster\&lt;/em\&gt." Development 133(11): 2223.

Chomczynski, P. and N. Sacchi (1987). "Single-step method of RNA isolation by acid guanidinium thiocyanate-phenol-chloroform extraction." Anal Biochem 162(1): 156159. 
Christiaens, O., M. Iga, et al. (2010). "Halloween genes and nuclear receptors in ecdysteroid biosynthesis and signalling in the pea aphid." Insect Mol Biol 19 Suppl 2: 187-200.

da Silva, R. and A. B. Lange (2006). "The association of crustacean cardioactive peptide with the spermatheca of the African migratory locust, Locusta migratoria." J Insect Physiol 52(4): 399-409.

Dai, L., E. M. Dewey, et al. (2008). "Identification, developmental expression, and functions of bursicon in the tobacco hawkmoth, Manduca sexta." J Comp Neurol 506(5): 759-774.

Davey, K. G. (1961). "The mode of action of the heart accelerating factor from the corpus cardiacum of insects." Gen Comp Endocrinol 1: 24-29.

Davis, N. T., D. Dulcis, et al. (2001). "Innervation of the heart and aorta of Manduca sexta." J Comp Neurol 440(3): 245-260.

Delaplane (2000). Pesticide Usage in the United States: History, Benefits, Risks, and Trends. Georgia, USA.

Delbecque, J. P., B. Lanzrein, et al. (1978). "Ecdysone and ecdysterone in physogastric termite queens and eggs of Macrotermes bellicosus and Macrotermes subhyalinus." Gen Comp Endocrinol 36(1): 40-47.

De Loof, A. Briers, T., et al. (1984). "Presence and function of ecdysteroids in adult insects." Comp Bioch and Phys Part B: Comp Bioch 79 (4): 505-509.

Devonshire, A. L. (1991). "Role of esterases in resistance of insects to insecticides." Biochem Soc Trans 19(3): 755-759.

Dewey, E. M., S. L. McNabb, et al. (2004). "Identification of the gene encoding bursicon, an insect neuropeptide responsible for cuticle sclerotization and wing spreading." Curr Biol 14(13): 1208-1213.

Di Cara, F. and K. King-Jones (2013). Chapter One - How Clocks and Hormones Act in Concert to Control the Timing of Insect Development. Curr Top Dev Biol. A. E. Rougvie and M. B. O'Connor, Academic Press. 105: 1-36.

Dias, J. C. (2015). "Evolution of Chagas disease screening programs and control programs: historical perspective." Glob Heart 10(3): 193-202.

Dillen, S., R. Verdonck, et al. (2014). "Identification of the short neuropeptide F precursor in the desert locust: evidence for an inhibitory role of sNPF in the control of feeding." Peptides 53: 134-139.

Dircksen, H., S. Burdzik, et al. (2000). "Two orcokinins and the novel octapeptide orcomyotropin in the hindgut of the crayfish Orconectes limosus: identified myostimulatory neuropeptides originating together in neurones of the terminal abdominal ganglion." J Exp Biol 203(Pt 18): 2807-2818.

Donini, A. and A. B. Lange (2002). "The effects of crustacean cardioactive peptide on locust oviducts are calcium-dependent." Peptides 23(4): 683-691.

Donini, A., C. Ngo, et al. (2002). "Evidence for crustacean cardioactive peptide-like innervation of the gut in Locusta migratoria." Peptides 23(11): 1915-1923.

du Rand, E. E., S. Smit, et al. (2015). "Detoxification mechanisms of honey bees (Apis mellifera) resulting in tolerance of dietary nicotine." Sci Rep 5: 11779.

Dubrovsky, E. B., V. A. Dubrovskaya, et al. (2004). "Hormonal regulation and functional role of Drosophila E75A orphan nuclear receptor in the juvenile hormone signaling pathway." Dev Biol 268(2): 258-270.

Ejaz, A. and A. B. Lange (2008). "Peptidergic control of the heart of the stick insect, Baculum extradentatum." Peptides 29(2): 214-225.

Enayati, A. A., H. Ranson, et al. (2005). "Insect glutathione transferases and insecticide resistance." Insect Mol Biol 14(1): 3-8.

EPA. (2017). from http://www.epa.gov/pesticides/.

Ewer, J. and J. W. Truman (1996). "Increases in cyclic 3', 5'-guanosine monophosphate (cGMP) occur at ecdysis in an evolutionarily conserved crustacean cardioactive peptideimmunoreactive insect neuronal network." J Comp Neurol 370(3): 330-341. 
Fabro, J., M. Sterkel, et al. (2012). "Identification of a point mutation associated with pyrethroid resistance in the para-type sodium channel of Triatoma infestans, a vector of Chagas' disease." Infect Genet Evol 12(2): 487-491.

Field, A. P. (2000). Discovering Statistics Using SPSS for Windows: Advanced Techniques for Beginners Thousand Oaks, CA, USA Sage Publications, Inc.

Fire, A. (1999). "RNA-triggered gene silencing." Trends Genet 15(9): 358-363.

Fire, A., S. Xu, et al. (1998). "Potent and specific genetic interference by double-stranded RNA in Caenorhabditis elegans." Nature 391(6669): 806-811.

Fire, A. Z. (2007). "Gene silencing by double-stranded RNA." Cell Death Differ 14(12): 19982012.

Fraenkel, G. and C. Hsiao (1962). "Hormonal and nervous control of tanning in the fly." Science 138(3536): 27-29.

Furuya, K., S. Liao, et al. (1993). "Isolation and identification of a cardioactive peptide from Tenebrio molitor and Spodoptera eridania." Biol Chem Hoppe Seyler 374(12): 10651074.

Gade, G. (1997). "The explosion of structural information on insect neuropeptides." Fortschr Chem Org Naturst 71: 1-128.

Gade, G., K. H. Hoffmann, et al. (1997). "Hormonal regulation in insects: facts, gaps, and future directions." Physiol Rev 77(4): 963-1032.

Gammie, S. C. and J. W. Truman (1997). "Neuropeptide hierarchies and the activation of sequential motor behaviors in the hawkmoth, Manduca sexta." J Neurosci 17(11): 4389-4397.

Gammie, S. C. and J. W. Truman (1999). "Eclosion hormone provides a link between ecdysistriggering hormone and crustacean cardioactive peptide in the neuroendocrine cascade that controls ecdysis behavior." J Exp Biol 202(Pt 4): 343-352.

Garcia, E. D. and M. L. Garcia (1977). "Control of protease secretion in the intestine of fifth instar larvae of Rhodnius prolixus." J Insect Physiol 23(2): 247-251.

Garcia, E. S. (1988). "Effects of precocene and azadirachtin on the development of Trypanosoma cruzi in Rhodnius prolixus." Mem Inst Oswaldo Cruz 83 Suppl 1: 578-579.

Garcia, E. S., D. Feder, et al. (1987). "Effects of precocene and azadirachtin in Rhodnius prolixus: some data on development and reproduction." Mem Inst Oswaldo Cruz 82 Suppl 3: 67-73.

Garland, S. L. (2013). "Are GPCRs still a source of new targets?" J Biomol Screen 18(9): 947-966.

Gilbert, L. I. (2012). Insect Endocrinology. London, Academic Press.

Gilbert, L. I., R. Rybczynski, et al. (2002). "Control and biochemical nature of the ecdysteroidogenic pathway." Annu Rev Entomol 47: 883-916.

Granger, N. A., J. D. MacDonald, et al. (1994). "Evidence of a stimulatory effect of cyclic AMP on corpus allatum activity in Manduca sexta." Mol Cell Endocrinol 103(1-2): 73-80.

Griss, C. (1990). "Mandibular motor neurons of the caterpillar of the hawk moth Manduca sexta." J Comp Neurol 296(3): 393-402.

Grosso, C. G., M. J. Blariza, et al. (2016). "Identification of three cytochrome P450 genes in the Chagas' disease vector Triatoma infestans: Expression analysis in deltamethrin susceptible and resistant populations." Infect Genet Evol 44: 459-470.

Guo, S. and K. J. Kemphues (1995). "par-1, a gene required for establishing polarity in C. elegans embryos, encodes a putative Ser/Thr kinase that is asymmetrically distributed." Cell 81(4): 611-620.

Hallberg, M. (2015). "Neuropeptides: Metabolism to Bioactive Fragments and the Pharmacology of Their Receptors." Med Res Rev 35(3): 464-519.

Hamoudi, Z., A. B. Lange, et al. (2016). "Identification and Characterization of the Corazonin Receptor and Possible Physiological Roles of the Corazonin-Signaling Pathway in Rhodnius prolixus." Front Neurosci 10: 357. 
Hardstone, M. C., J. P. Strycharz, et al. (2015). "Development of multifunctional metabolic synergists to suppress the evolution of resistance against pyrethroids in insects that blood feed on humans." Pest Manag Sci 71(6): 842-849.

Harrison, R. L. and B. C. Bonning (2010). "Proteases as insecticidal agents." Toxins (Basel) 2(5): 935-953.

Hauser, F., G. Cazzamali, et al. (2008). "A genome-wide inventory of neurohormone GPCRs in the red flour beetle Tribolium castaneum." Front Neuroendocrinol 29(1): 142-165.

Hauser, F., S. Neupert, et al. (2010). "Genomics and peptidomics of neuropeptides and protein hormones present in the parasitic wasp Nasonia vitripennis." J Proteome Res 9(10): 5296-5310.

Hauser, F., M. Williamson, et al. (2006). "Identifying neuropeptide and protein hormone receptors in Drosophila melanogaster by exploiting genomic data." Brief Funct Genomic Proteomic 4(4): 321-330.

Hentze, J. L., M. E. Moeller, et al. (2013). "Accessory gland as a site for prothoracicotropic hormone controlled ecdysone synthesis in adult male insects." PLoS One 8(2): e55131.

Hewes, R. S. and P. H. Taghert (2001). "Neuropeptides and neuropeptide receptors in the Drosophila melanogaster genome." Genome Res 11(6): 1126-1142.

Hiruma, K. (1980). "Possible roles of juvenile hormone in the prepupal stage of Mamestra brassicae." Gen Comp Endocrinol 41(3): 392-399.

Hiruma, K. and L. M. Riddiford (1984). "Regulation of melanization of tobacco hornworm larval cuticle in vitro." J Exp Zool 230(3): 393-403.

Hiruma, K. and L. M. Riddiford (1988). "Granular phenoloxidase involved in cuticular melanization in the tobacco hornworm: regulation of its synthesis in the epidermis by juvenile hormone." Dev Biol 130(1): 87-97.

Hofer, S., H. Dircksen, et al. (2005). "Novel insect orcokinins: characterization and neuronal distribution in the brains of selected dicondylian insects." J Comp Neurol 490(1): 57-71.

Hofer, S. and U. Homberg (2006). "Orcokinin immunoreactivity in the accessory medulla of the cockroach Leucophaea maderae." Cell Tissue Res 325(3): 589-600.

Honegger, H. W., E. M. Dewey, et al. (2008). "Bursicon, the tanning hormone of insects: recent advances following the discovery of its molecular identity." J Comp Physiol A Neuroethol Sens Neural Behav Physiol 194(12): 989-1005.

Honegger, H. W., D. Market, et al. (2002). "Cellular localization of bursicon using antisera against partial peptide sequences of this insect cuticle-sclerotizing neurohormone." J Comp Neurol 452(2): 163-177.

Hou, Q. L., H. B. Jiang, et al. (2017). "A Role of Corazonin Receptor in Larval-Pupal Transition and Pupariation in the Oriental Fruit Fly Bactrocera dorsalis (Hendel) (Diptera: Tephritidae)." Front Physiol 8: 77.

Houseman, R. M. (2007). Silverfish and Firebrats Insects and diseases. U. O. Missouri. Columbia, USA.

Hua, Y. J., Y. Tanaka, et al. (1999). "Identification of a prothoracicostatic peptide in the larval brain of the silkworm, Bombyx mori." J Biol Chem 274(44): 31169-31173.

Huang, Q., H. M. Lattorff, et al. (2014). "A selective sweep in a microsporidian parasite Nosema-tolerant honeybee population, Apis mellifera." Anim Genet 45(2): 267-273.

Hughes, G. (1980). "Larval competition in serially transferred populations of Drosophila melanogaster." Oecologia 45(3): 396-403.

Hummon, A. B., T. A. Richmond, et al. (2006). "From the genome to the proteome: uncovering peptides in the Apis brain." Science 314(5799): 647-649.

Husak, J. F. (2015). "Integrative Organismal Biology edited by Lynn B. Martin, Cameron K. Ghalambor, and H. Arthur Woods." Q Rev Biol 90(4): 431-432.

lanowski, J. P., J. P. Paluzzi, et al. (2010). "The antidiuretic neurohormone RhoprCAPA-2 downregulates fluid transport across the anterior midgut in the blood-feeding insect Rhodnius prolixus." Am J Physiol Regul Integr Comp Physiol 298(3): R548-557. 
Iga, M. and G. Smagghe (2010). "Identification and expression profile of Halloween genes involved in ecdysteroid biosynthesis in Spodoptera littoralis." Peptides 31(3): 456-467.

Insausti, T. C. (1994). "Nervous system of Triatoma infestans." J Morphol 221(3): 343-359.

IRAC. (2015). "Insecticide Resistance Action Committee." Retrieved 11/23/2017, 2015, from http://www.irac-online.org/.

Jiang, H., H. G. Kim, et al. (2015). "Alternatively spliced orcokinin isoforms and their functions in Tribolium castaneum." Insect Biochem Mol Biol 65: 1-9.

Jindra, M., F. Sehnal, et al. (1994). "Isolation, characterization and developmental expression of the ecdysteroid-induced E75 gene of the wax moth Galleria mellonella." Eur J Biochem 221(2): 665-675.

Jorgensen, R. (1990). "Altered gene expression in plants due to trans interactions between homologous genes." Trends Biotechnol 8(12): 340-344.

Jung, H. J., R. K. Manoharan, et al. (2014). "Identification of Yellow Pigmentation Genes in Brassica rapa ssp. pekinensis Using Br300 Microarray." Int J Genomics 2014: 204969.

Kaczmarek, K., H. J. Williams, et al. (2007). "Comparison of insect kinin analogs with cis-peptide bond motif 4-aminopyroglutamate identifies optimal stereochemistry for diuretic activity." Biopolymers 88(1): 1-7.

Kaneko, Y. and K. Hiruma (2014). "Short neuropeptide F (sNPF) is a stage-specific suppressor for juvenile hormone biosynthesis by corpora allata, and a critical factor for the initiation of insect metamorphosis." Dev Biol 393(2): 312-319.

Kapp K, S. S., Lemberg MK, et al. Post-Targeting Functions of Signal Peptides. Landes, Madame Curie Bioscience Database [Internet]. Austin (TX): Landes Bioscience; 2000-2013. .

Kaps, M. a. L., W, R. (2009). Biostatistics for animal science. An introductory text. Cambridge, Cabi publising.

Kataoka, H., H. Nagasawa, et al. (1991). "Prothoracicotropic hormone of the silkworm, Bombyx mori: amino acid sequence and dimeric structure." Agric Biol Chem 55(1): 73-86.

Ketting, R. F. (2011). "microRNA Biogenesis and Function : An overview." Adv Exp Med Biol 700: 1-14.

Kim, Y. J., I. Spalovska-Valachova, et al. (2004). "Corazonin receptor signaling in ecdysis initiation." Proc Natl Acad Sci U S A 101(17): 6704-6709.

Kim, Y. J., D. Zitnan, et al. (2006). "Central peptidergic ensembles associated with organization of an innate behavior." Proc Natl Acad Sci U S A 103(38): 14211-14216.

Kim, Y. J., D. Zitnan, et al. (2006). "A command chemical triggers an innate behavior by sequential activation of multiple peptidergic ensembles." Curr Biol 16(14): 1395-1407.

Kimon, I. E. R. (1913). Experimental Anatomy and Physiology of Bombyx mori. Ikeda. Tokyo, Japan Meibundo.

King-Jones, K., J.-P. Charles, et al. "The Ecdysone-Induced DHR4 Orphan Nuclear Receptor Coordinates Growth and Maturation in <em>Drosophila</em>." Cell 121(5): 773-784.

King, D. S. and J. B. Siddall (1969). "Conversion of alpha ecdysone to beta ecdysone by crustaceans and insects." Nature 221(5184): 955-956.

Kingan, T. G., W. Gray, et al. (1997). "Regulation of ecdysis-triggering hormone release by eclosion hormone." J Exp Biol 200(Pt 24): 3245-3256.

Kingsolver, M. B., Z. Huang, et al. (2013). "Insect antiviral innate immunity: pathways, effectors, and connections." J Mol Biol 425(24): 4921-4936.

Kleinfeld, M., J. Magin, et al. (1960). "The effect of tetraethyl-pyrophosphate (TEPP) on the transmembrane potentials of pacemaker and non-pacemaker fibers of isolated rabbit atrium." Circ Res 8: 240-245.

Klendshoj, N. C., W. G. Moran, et al. (1952). "Poisoning from tetraethylpyrophosphate (tepp)." J Am Med Assoc 149(11): 1015.

Klowden, M. (2013). Physiological Systems in Insects, Academic Press. 
Kono, T., H. Nagasawa, et al. (1990). "Eclosion hormone of the silkworm Bombyx mori. Expression in Escherichia coli and location of disulfide bonds." FEBS Lett 263(2): 358360.

Konopova, B. and M. Jindra (2007). "Juvenile hormone resistance gene Methoprene-tolerant controls entry into metamorphosis in the beetle Tribolium castaneum." Proc Natl Acad Sci U S A 104(25): 10488-10493.

Kostron, B., U. Kaltenhauser, et al. (1996). "Localization of bursicon in CCAP-immunoreactive cells in the thoracic ganglia of the cricket Gryllus bimaculatus." J Exp Biol 199(Pt 2): 367-377.

Kostron, B., D. Market, et al. (1999). "Antisera against Periplaneta americana Cu,Zn-superoxide dismutase (SOD): separation of the neurohormone bursicon from SOD, and immunodetection of SOD in the central nervous system." Insect Biochem Mol Biol 29(10): 861-871.

Kostron, B., K. Marquardt, et al. (1995). "Bursicon, the cuticle sclerotizing hormonecomparison of its molecular mass in different insects." J Insect Physiol 41(12): 10451053.

Kostyukovsky, M., B. Chen, et al. (2000). "Biological activity of two juvenoids and two ecdysteroids against three stored product insects." Insect Biochem Mol Biol 30(8-9): 891-897.

Kriger, F. L. and K. G. Davey (1982). "Ovarian motility in mated Rhodnius prolixus requires an intact cerebral neurosecretory system." Gen Comp Endocrinol 48(1): 130-134.

Kristensen, M. (2005). "Glutathione S-transferase and insecticide resistance in laboratory strains and field populations of Musca domestica." J Econ Entomol 98(4): 1341-1348.

Lalah, J. O., C. I. Chien, et al. (1995). "Glutathione S-transferases: alpha-naphthyl acetate activity and possible role in insecticide resistance." J Econ Entomol 88(4): 768-770.

Lange, A. B., R. J. Nachman, et al. (2016). "Biostable insect kinin analogs reduce blood meal and disrupt ecdysis in the blood-gorging Chagas' disease vector, Rhodnius prolixus." Peptides 80: 108-113.

Lange, A. B., I. Orchard, et al. (1995). "A nonpeptide agonist of the invertebrate receptor for SchistoFLRFamide (PDVDHVFLRFamide), a member of a subfamily of insect FMRFamide-related peptides." Proc Natl Acad Sci U S A 92(20): 9250-9253.

Lange, A. B. and K. Patel (2005). "The presence and distribution of crustacean cardioactive peptide in the central and peripheral nervous system of the stick insect, Baculum extradentatum." Regul Pept 129(1-3): 191-201.

Lardeux, F., S. Depickere, et al. (2010). "Insecticide resistance of Triatoma infestans (Hemiptera, Reduviidae) vector of Chagas disease in Bolivia." Trop Med Int Health 15(9): 1037-1048.

Leach, P. H. (1953). "Organic phosphorus poisoning in general practice; parathion, TEPP, HEPT, EPN and others." Calif Med 78(6): 491-495.

Leander, M., C. Bass, et al. (2015). "Cardiac contractility structure-activity relationship and ligand-receptor interactions; the discovery of unique and novel molecular switches in myosuppressin signaling." PLoS One 10(3): e0120492.

Lee, D., I. Orchard, et al. (2013). "Evidence for a conserved CCAP-signaling pathway controlling ecdysis in a hemimetabolous insect, Rhodnius prolixus." Front Neurosci 7: 207.

Lee, D., H. Taufique, et al. (2012). "An unusual myosuppressin from the blood-feeding bug \&lt;em\&gt;Rhodnius prolixus\&lt;/em\&gt." J Exp Biol 215(12): 2088.

Lee, D., H. Taufique, et al. (2012). "An unusual myosuppressin from the blood-feeding bug Rhodnius prolixus." J Exp Biol 215(Pt 12): 2088-2095.

Lee, D., J. Vanden Broeck, et al. (2013). "Identification and expression of the CCAP receptor in the Chagas' disease vector, Rhodnius prolixus, and its involvement in cardiac control." PLoS One 8(7): e68897. 
Lee, D. H. and A. B. Lange (2011). "Crustacean cardioactive peptide in the Chagas' disease vector, Rhodnius prolixus: presence, distribution and physiological effects." Gen Comp Endocrinol 174(1): 36-43.

Lee, G., K. M. Kim, et al. (2008). "Developmental regulation and functions of the expression of the neuropeptide corazonin in Drosophila melanogaster." Cell Tissue Res 331(3): 659673.

Lee, G., R. Sehgal, et al. (2013). "Essential role of grim-led programmed cell death for the establishment of corazonin-producing peptidergic nervous system during embryogenesis and metamorphosis in Drosophila melanogaster." Biol Open 2(3): 283294.

Lehman, H. K., C. M. Murgiuc, et al. (1993). "Crustacean cardioactive peptide in the sphinx moth, Manduca sexta." Peptides 14(4): 735-741.

Lenaerts, C., D. Cools, et al. (2017). "The ecdysis triggering hormone system is essential for successful moulting of a major hemimetabolous pest insect, Schistocerca gregaria." Sci Rep 7: 46502.

Lenaerts, C., P. Van Wielendaele, et al. (2016). "Ecdysteroid signalling components in metamorphosis and development of the desert locust, Schistocerca gregaria." Insect Biochem Mol Biol 75: 10-23.

Lewis, J. R., W. B. McKeon, Jr., et al. (1955). "Effect of various drugs in antagonizing the toxicity of TEPP." Arch Int Pharmacodyn Ther 102(4): 371-390.

Li, B., R. Predel, et al. (2008). "Genomics, transcriptomics, and peptidomics of neuropeptides and protein hormones in the red flour beetle Tribolium castaneum." Genome Res 18(1): 113-122.

Li, Z., B. Zeng, et al. (2015). "Enhancement of larval RNAi efficiency by over-expressing Argonaute2 in Bombyx mori." Int J Biol Sci 11(2): 176-185.

Loof, A. (2008). Ecdysteroids, juvenile hormone and insect neuropeptides: Recent successes and remaining major challenges.

Loof, A., B. Boerjan, et al. (2013). The mode of action of juvenile hormone and ecdysone: Towards an epi-endocrinological paradigm?

Lorenz, M. W., R. Kellner, et al. (1995). "A family of neuropeptides that inhibit juvenile hormone biosynthesis in the cricket, Gryllus bimaculatus." J Biol Chem 270(36): 2110321108.

Luo, C. W., E. M. Dewey, et al. (2005). "Bursicon, the insect cuticle-hardening hormone, is a heterodimeric cystine knot protein that activates G protein-coupled receptor LGR2." Proc Natl Acad Sci U S A 102(8): 2820-2825.

Ma, M., K. K. Kutz-Naber, et al. (2007). "Methyl esterification assisted MALDI FTMS characterization of the orcokinin neuropeptide family." Anal Chem 79(2): 673-681.

Maestro, J. L. and X. Belles (2006). "Silencing allatostatin expression using double-stranded RNA targeted to preproallatostatin mRNA in the German cockroach." Arch Insect Biochem Physiol 62(2): 73-79.

Majerowicz, D., M. Alves-Bezerra, et al. (2011). "Looking for reference genes for real-time quantitative PCR experiments in Rhodnius prolixus (Hemiptera: Reduviidae)." Insect Mol Biol 20(6): 713-722.

Mansur, J. F., E. S. Alvarenga, et al. (2014). "Effects of chitin synthase double-stranded RNA on molting and oogenesis in the Chagas disease vector Rhodnius prolixus." Insect Biochem Mol Biol 51: 110-121.

Marchal, E., H. P. Vandersmissen, et al. (2010). "Control of ecdysteroidogenesis in prothoracic glands of insects: a review." Peptides 31(3): 506-519.

Matsui, T., T. Sakai, et al. (2013). "The pars intercerebralis affects digestive activities of the American cockroach, Periplaneta Americana, via crustacean cardioactive peptide and allatostatin-A." J Insect Physiol 59(1): 33-37. 
Matsumoto, H., C. Ueno, et al. (2015). "Identification of two juvenile hormone inducible transcription factors from the silkworm, Bombyx mori." J Insect Physiol 80: 31-41.

Matsumoto, S., A. Kitamura, et al. (1990). "Functional diversity of a neurohormone produced by the suboesophageal ganglion: Molecular identity of melanization and reddish colouration hormone and pheromone biosynthesis activating neuropeptide." $\underline{\mathrm{J} \text { Insect }}$ Physiol 36(6): 427-432.

McCleery, R. H. W., T. A. and Hart, T. (2007). Introduction to statistic for biology Boca Raton, CRC Press.

Meiselman, M., S. S. Lee, et al. (2017). "Endocrine network essential for reproductive success in Drosophila melanogaster." Proc Natl Acad Sci U S A 114(19): E3849-E3858.

Meister, G. and T. Tuschl (2004). "Mechanisms of gene silencing by double-stranded RNA." Nature 431(7006): 343-349.

Mendive, F. M., T. Van Loy, et al. (2005). "Drosophila molting neurohormone bursicon is a heterodimer and the natural agonist of the orphan receptor DLGR2." FEBS Lett 579(10): 2171-2176.

Meredith, J., M. Ring, et al. (1996). "Locust ion transport peptide (ITP): primary structure, cDNA and expression in a baculovirus system." J Exp Biol 199(Pt 5): 1053-1061.

Mesce, K. A. and S. E. Fahrbach (2002). "Integration of endocrine signals that regulate insect ecdysis." Front Neuroendocrinol 23(2): 179-199.

Mesquita, R. D., R. J. Vionette-Amaral, et al. (2015). "Genome of Rhodnius prolixus, an insect vector of Chagas disease, reveals unique adaptations to hematophagy and parasite infection." Proc Natl Acad Sci U S A 112(48): 14936-14941.

Miao, Y. and J. A. McCammon (2016). "G-protein coupled receptors: advances in simulation and drug discovery." Curr Opin Struct Biol 41: 83-89.

Micks, D. W. (1960). "Insecticide-resistance: A review of developments in 1958 and 1959." Bull World Health Organ 22(5): 519-529.

Micks, D. W., M. J. Ferguson, et al. (1960). "Effect of DDT on Free Amino Acids of Susceptible and DDT-Resistant Aedes aegypti Larvae." Science 131(3413): 1615.

Milani, R. (1957). "[Genetic studies of the resistance of insects to the action of toxic substances]." Rend Ist Sup Sanit 20(7-8): 713-772.

Miles, M. A. (2004). "The discovery of Chagas disease: progress and prejudice." Infect Dis Clin North Am 18(2): 247-260, table of contents.

Miller, S. C., K. Miyata, et al. (2012). "Dissecting systemic RNA interference in the red flour beetle Tribolium castaneum: parameters affecting the efficiency of RNAi." PLoS One 7(10): e47431.

Moffatt, M. R., D. Blakemore, et al. (1995). "Studies on the synthesis and secretion of trypsin in the midgut of Stomoxys calcitrans." Comparative Biochemistry and Physiology Part B: Biochemistry and Molecular Biology 110(2): 291-300.

Monteiro, F. A., I. Cardoso, et al. (2006). "In vitro inhibition of transthyretin aggregate-induced cytotoxicity by full and peptide derived forms of the soluble receptor for advanced glycation end products (RAGE)." FEBS Lett 580(14): 3451-3456.

Monteiro, F. A., A. A. Escalante, et al. (2001). "Molecular tools and triatomine systematics: a public health perspective." Trends Parasitol 17(7): 344-347.

Montgomery, M. K. and A. Fire (1998). "Double-stranded RNA as a mediator in sequencespecific genetic silencing and co-suppression." Trends Genet 14(7): 255-258.

Morton, D. B. and J. W. Truman (1988). "The EGPs: the eclosion hormone and cyclic GMPregulated phosphoproteins. II. Regulation of appearance by the steroid hormone 20hydroxyecdysone in Manduca sexta." J Neurosci 8(4): 1338-1345.

Mykles, D. L., M. E. Adams, et al. (2010). "Neuropeptide action in insects and crustaceans." Physiol Biochem Zool 83(5): 836-846. 
Mysore, K., E. M. Flannery, et al. (2013). "Disruption of Aedes aegypti olfactory system development through chitosan/siRNA nanoparticle targeting of semaphorin-1a." PLoS Negl Trop Dis 7(5): e2215.

Nachman, R. J., O. Ben Aziz, et al. (2010). "A novel dihydroimidazoline, trans-Pro mimetic analog is a selective PK/PBAN agonist." Front Biosci (Elite Ed) 2: 195-203.

Nachman, R. J., J. A. Fehrentz, et al. (2007). "A C-terminal aldehyde analog of the insect kinins inhibits diuresis in the housefly." Peptides 28(1): 146-152.

Nachman, R. J., G. M. Holman, et al. (1991). "An active pseudopeptide analog of the leucokinin insect neuropeptide family." Int J Pept Protein Res 37(3): 220-223.

Nachman, R. J., K. Kaczmarek, et al. (2012). "Active diuretic peptidomimetic insect kinin analogs that contain beta-turn mimetic motif 4-aminopyroglutamate and lack native peptide bonds." Peptides 34(1): 262-265.

Nachman, R. J., E. H. Olender, et al. (1996). "A nonpeptidal peptidomimetic agonist of the insect FLRFamide myosuppressin family." Peptides 17(2): 313-320.

Nachman, R. J., P. V. Pietrantonio, et al. (2009). "Toward the development of novel pest management agents based upon insect kinin neuropeptide analogues." Ann N Y Acad Sci 1163: 251-261.

Nachman, R. J., V. A. Roberts, et al. (1995). "Pseudodipeptide analogs of the pyrokinin/PBAN (FXPRLa) insect neuropeptide family containing carbocyclic Pro-mimetic conformational components." Regul Pept 57(3): 359-370.

Nagasawa, H., H. Kataoka, et al. (1984). "Isolation and some characterization of the prothoracicotropic hormone from Bombyx mori." Gen Comp Endocrinol 53(1): 143152.

Nassel, D. R. (2002). "Neuropeptides in the nervous system of Drosophila and other insects: multiple roles as neuromodulators and neurohormones." Prog Neurobiol 68(1): 1-84.

Nassel, D. R. and A. M. Winther (2010). "Drosophila neuropeptides in regulation of physiology and behavior." Prog Neurobiol 92(1): 42-104.

Nielsen, H., J. Engelbrecht, et al. (1997). "Identification of prokaryotic and eukaryotic signal peptides and prediction of their cleavage sites." Protein Eng 10(1): 1-6.

Niwa, R. and Y. S. Niwa (2014). "Enzymes for ecdysteroid biosynthesis: their biological functions in insects and beyond." Biosci Biotechnol Biochem 78(8): 1283-1292.

Oberemok, V. V., A. S. Zaitsev, et al. (2015). "A brief review of most widely used modern insecticides and prospects for the creation of DNA insecticides." Entomological Review 95(7): 824-831.

Okamoto, N., N. Yamanaka, et al. (2009). "An ecdysteroid-inducible insulin-like growth factorlike peptide regulates adult development of the silkmoth Bombyx mori." FEBS J 276(5): 1221-1232.

Okamoto, N., N. Yamanaka, et al. (2009). "A fat body-derived IGF-like peptide regulates postfeeding growth in Drosophila." Dev Cell 17(6): 885-891.

Omondi, B. A., J. M. Latorre-Estivalis, et al. (2015). "Evaluation of reference genes for insect olfaction studies." Parasit Vectors 8: 243.

OMS. (2017). "http://www.who.int/gho/database/es/." Retrieved 12/11/17, 2017, from http://www.who.int/gho/database/es/.

Ons, S. (2017). "Neuropeptides in the regulation of Rhodnius prolixus physiology." J Insect Physiol 97: 77-92.

Ons, S., X. Belles, et al. (2015). "Orcokinins contribute to the regulation of vitellogenin transcription in the cockroach Blattella germanica." J Insect Physiol 82: 129-133.

Ons, S., A. Lavore, et al. (2016). "Identification of G protein coupled receptors for opsines and neurohormones in Rhodnius prolixus. Genomic and transcriptomic analysis." Insect Biochem Mol Biol 69: 34-50.

Ons, S., F. Richter, et al. (2009). "The neuropeptidome of Rhodnius prolixus brain." PROTEOMICS 9(3): 788-792. 
Ons, S., M. Sterkel, et al. (2011). "Neuropeptide precursor gene discovery in the Chagas disease vector Rhodnius prolixus." Insect Mol Biol 20(1): 29-44.

Oppenoorth, F. J. (1971). "Resistance in insects: the role of metabolism and the possible use of synergists." Bull World Health Organ 44(1-3): 195-202.

Orchard, I. and V. T. Brugge (2002). "Contractions associated with the salivary glands of the blood-feeding bug, Rhodnius prolixus: evidence for both a neural and neurohormonal coordination." Peptides 23(4): 693-700.

Orchard, I., D. H. Lee, et al. (2011). "The Proctolin Gene and Biological Effects of Proctolin in the Blood-Feeding Bug, Rhodnius prolixus." Front Endocrinol (Lausanne) 2: 59.

Orchard, I. and C. G. Steel (1980). "Electrical activity of neurosecretory axons from the brain of Rhodnius prolixus: relation of changes in the pattern of activity to endocrine events during the moulting cycle." Brain Res 191(1): 53-65.

Paim, R. M., R. N. Araujo, et al. (2013). "Application of RNA interference in triatomine (Hemiptera: Reduviidae) studies." Insect Sci 20(1): 40-52.

Paluzzi, J. P. (2012). "Anti-diuretic factors in insects: the role of CAPA peptides." Gen Comp Endocrinol 176(3): 300-308.

Paluzzi, J. P., W. Naikkhwah, et al. (2012). "Natriuresis and diuretic hormone synergism in R. prolixus upper Malpighian tubules is inhibited by the anti-diuretic hormone, RhoprCAPA-alpha2." J Insect Physiol 58(4): 534-542.

Paluzzi, J. P. and I. Orchard (2006). "Distribution, activity and evidence for the release of an anti-diuretic peptide in the kissing bug Rhodnius prolixus." J Exp Biol 209(Pt 5): 907915.

Paluzzi, J. P. and I. Orchard (2010). "A second gene encodes the anti-diuretic hormone in the insect, Rhodnius prolixus." Mol Cell Endocrinol 317(1-2): 53-63.

Paluzzi, J. P., Y. Park, et al. (2010). "Isolation, expression analysis, and functional characterization of the first antidiuretic hormone receptor in insects." Proc Natl Acad Sci U S A 107(22): 10290-10295.

Paluzzi, J. P., W. K. Russell, et al. (2008). "Isolation, cloning, and expression mapping of a gene encoding an antidiuretic hormone and other CAPA-related peptides in the disease vector, Rhodnius prolixus." Endocrinology 149(9): 4638-4646.

Palli, S. R., T. R. Ladd, et al. (1997). "Cloning and development expression of Choristoneura hormone receptor 75: a homologue of the Drosophila E75A gene." Dev Genet 20(1): 36-46.

Park, Y., D. Zitnan, et al. (1999). "Molecular cloning and biological activity of ecdysis-triggering hormones in Drosophila melanogaster." FEBS Lett 463(1-2): 133-138.

Pascual, N., X. Belles, et al. (1995). "Quantification of ecdysteroids by immunoassay: comparison of enzyme immunoassay and radioimmunoassay." Z Naturforsch C 50(1112): 862-867.

Pascual, N., J. Castresana, et al. (2004). "Orcokinins in insects and other invertebrates." Insect Biochem Mol Biol 34(11): 1141-1146.

Patel, H., I. Orchard, et al. (2014). "The distribution and physiological effects of three evolutionarily and sequence-related neuropeptides in Rhodnius prolixus: Adipokinetic hormone, corazonin and adipokinetic hormone/corazonin-related peptide." Gen Comp Endocrinol 195: 1-8.

Patterson, J. W. and M. Schwarz (1977). "Chemical structure, juvenile hormone activity and persistence within the insect of juvenile hormone mimics for Rhodnius prolixus." J Insect Physiol 23(1): 121-129.

Pavlidi, N., V. Tseliou, et al. (2015). "Functional characterization of glutathione S-transferases associated with insecticide resistance in Tetranychus urticae." Pestic Biochem Physiol 121: $53-60$. 
Peabody, N. C., J. B. Pohl, et al. (2009). "Characterization of the decision network for wing expansion in Drosophila using targeted expression of the TRPM8 channel." $\underline{\mathrm{J} \text { Neurosci }}$ 29(11): 3343-3353.

Pedrini, N., S. J. Mijailovsky, et al. (2009). "Control of pyrethroid-resistant Chagas disease vectors with entomopathogenic fungi." PLoS Negl Trop Dis 3(5): e434.

Pedrini, N., S. Zhang, et al. (2010). "Molecular characterization and expression analysis of a suite of cytochrome P450 enzymes implicated in insect hydrocarbon degradation in the entomopathogenic fungus Beauveria bassiana." Microbiology 156(Pt 8): 25492557.

Pessoa, G. C., M. T. Obara, et al. (2015). "Deltamethrin toxicological profile of peridomestic Triatoma sordida in the North of Minas Gerais, Brazil." Parasit Vectors 8: 263.

Petersen, T. N., S. Brunak, et al. (2011). "SignalP 4.0: discriminating signal peptides from transmembrane regions." Nat Methods 8(10): 785-786.

Pfaffl, M. W. (2001). "A new mathematical model for relative quantification in real-time RTPCR." Nucleic Acids Res 29(9): e45.

Phillips, J. E. and A. A. Dockrill (1968). "Molecular sieving of hydrophilic molecules by the rectal intima of the desert locust (Schistocerca gregaria)." J Exp Biol 48(3): 521-532.

Picollo, M. I., C. Vassena, et al. (2005). "High resistance to pyrethroid insecticides associated with ineffective field treatments in Triatoma infestans (Hemiptera: Reduviidae) from Northern Argentina." J Med Entomol 42(4): 637-642.

Pipa, R. L. (1978). "Locations and central projections of neurons associated with the retrocerebral neuroendocrine complex of the cockroach Periplaneta americana (L.)." Cell Tissue Res 193(3): 443-455.

Predel, R., S. Neupert, et al. (2007). "Corazonin in insects." Peptides 28(1): 3-10.

Pridgeon, J. W., L. Zhao, et al. (2008). "Topically applied AaelAP1 double-stranded RNA kills female adults of Aedes aegypti." J Med Entomol 45(3): 414-420.

Puricelli (2016). Mecanismos de acción de plaguicidas. La plata, Fac Cs Agrarias. UNLP.

Rasmussen, L. D., F. Ekelund, et al. (2001). "Group-Specific PCR Primers to Amplify 24S aSubunit rRNA Genes from Kinetoplastida (Protozoa) Used in Denaturing Gradient Gel Electrophoresis." Microb Ecol 42(2): 109-115.

Rassi, A., Jr., A. Rassi, et al. (2010). "Chagas disease." Lancet 375(9723): 1388-1402.

Resh, V. H. a. C., R. T. (2009). Encyclopedia of Insects. University of California, Berkeley, USA, Academic Press.

Riccillo FL, Ronderos JR (2010). Allatotropin expression during the development of the fourth instar larvae of the kissing-bug Triatoma infestans (Klüg). Tissue Cell 42: 355-359

Richards, S., R. A. Gibbs, et al. (2008). "The genome of the model beetle and pest Tribolium castaneum." Nature 452(7190): 949-955.

Riehle, M. A., S. F. Garczynski, et al. (2002). "Neuropeptides and peptide hormones in Anopheles gambiae." Science 298(5591): 172-175.

Roller, L., I. Zitnanova, et al. (2010). "Ecdysis triggering hormone signaling in arthropods." Peptides 31(3): 429-441.

Romano, N. and G. Macino (1992). "Quelling: transient inactivation of gene expression in Neurospora crassa by transformation with homologous sequences." Mol Microbiol 6(22): 3343-3353.

Romanova, E. V. and J. V. Sweedler (2015). "Peptidomics for the discovery and characterization of neuropeptides and hormones." Trends Pharmacol Sci 36(9): 579-586.

Sakai, T., H. Satake, et al. (2004). "Characterization of crustacean cardioactive peptide as a novel insect midgut factor: isolation, localization, and stimulation of alpha-amylase activity and gut contraction." Endocrinology 145(12): 5671-5678.

Sakai, T., H. Satake, et al. (2006). "Nutrient-induced alpha-amylase and protease activity is regulated by crustacean cardioactive peptide (CCAP) in the cockroach midgut." Peptides 27(9): 2157-2164. 
Sawicki, R. M. (1975). "Interactions between different factors or mechanisms of resistance to insecticides in insects." Environ Qual Saf Suppl 3: 429-436.

Scott, J. G., K. Michel, et al. (2013). "Towards the elements of successful insect RNAi." J Insect Physiol 59(12): 1212-1221.

Schoofs, L., G. M. Holman, et al. (1991). "Isolation, identification and synthesis of locustamyoinhibiting peptide (LOM-MIP), a novel biologically active neuropeptide from Locusta migratoria." Regul Pept 36(1): 111-119.

Schoofs, L., J. Vanden Broeck, et al. (1993). "The myotropic peptides of Locusta migratoria: structures, distribution, functions and receptors." Insect Biochem Mol Biol 23(8): 859881.

Schoofs, L., D. Veelaert, et al. (1996). "Immunocytochemical distribution of locustamyoinhibiting peptide (Lom-MIP) in the nervous system of Locusta migratoria." Regul Pept 63(2-3): 171-179.

Schoofs, L., D. Veelaert, et al. (1997). "Peptides in the locusts, Locusta migratoria and Schistocerca gregaria." Peptides 18(1): 145-156.

Schwartz, L. M. and J. W. Truman (1982). "Peptide and steroid regulation of muscle degeneration in an insect." Science 215(4538): 1420-1421.

Sedra, L., A. S. Haddad, et al. (2015). "Myoinhibitors controlling oviduct contraction within the female blood-gorging insect, Rhodnius prolixus." Gen Comp Endocrinol 211: 62-68.

Sedra, L. and A. B. Lange (2014). "The female reproductive system of the kissing bug, Rhodnius prolixus: arrangements of muscles, distribution and myoactivity of two endogenous FMRFamide-like peptides." Peptides 53: 140-147.

Sedra, L. and A. B. Lange (2016). "Cloning and expression of long neuropeptide F and the role of FMRFamide-like peptides in regulating egg production in the Chagas vector, Rhodnius prolixus." Peptides 82: 1-11.

Sevala, V. L., V. M. Sevala, et al. (1992). "A FMRFamide-like peptide is associated with the myotropic ovulation hormone in Rhodnius prolixus." Arch Insect Biochem Physiol 20(3): 193-203.

Shabalina, S. A. and E. V. Koonin (2008). "Origins and evolution of eukaryotic RNA interference." Trends Ecol Evol 23(10): 578-587.

Sierra, I., N. Capriotti, et al. (2016). "Kdr mutations in Triatoma infestans from the Gran Chaco are distributed in two differentiated foci: Implications for pyrethroid resistance management." Acta Trop 158: 208-213.

Siga, S. (2003). "Anatomy and functions of brain neurosecretory cells in diptera." Microsc Res Tech 62(2): 114-131.

Singh, R., A. L. Levitt, et al. (2010). "RNA viruses in hymenopteran pollinators: evidence of inter-Taxa virus transmission via pollen and potential impact on non-Apis hymenopteran species." PLoS One 5(12): e14357.

Smith, A. E. and D. M. Secoy (1975). "Forerunners of pesticides in classical Greece and Rome." J Agric Food Chem 23(6): 1050-1055.

Smith, A. E. and D. M. Secoy (1976). "A compendium of inorganic substances used in European pest control before 1850." J Agric Food Chem 24(6): 1180-1186.

Smykal, V., A. Bajgar, et al. (2014). "Juvenile hormone signaling during reproduction and development of the linden bug, Pyrrhocoris apterus." Insect Biochem Mol Biol 45: 6976.

Sokal, R. R. y. R., F. J. (1980). Introducción a la Bioestadística. Barcelona, Reverté.

Sossin, W. S., J. M. Fisher, et al. (1989). "Cellular and molecular biology of neuropeptide processing and packaging." Neuron 2(5): 1407-1417.

Stangier, J., C. Hilbich, et al. (1987). "Unusual cardioactive peptide (CCAP) from pericardial organs of the shore crab Carcinus maenas." Proc Natl Acad Sci U S A 84(2): 575-579.

Stangier, J., C. Hilbich, et al. (1992). "Orcokinin: a novel myotropic peptide from the nervous system of the crayfish, Orconectes limosus." Peptides 13(5): 859-864. 
Stay, B. (2000). "A review of the role of neurosecretion in the control of juvenile hormone synthesis: a tribute to Berta Scharrer." Insect Biochem Mol Biol 30(8-9): 653-662.

Stay, B., S. Fairbairn, et al. (1996). "Role of allatostatins in the regulation of juvenile hormone synthesis." Arch Insect Biochem Physiol 32(3-4): 287-297.

Stay, B. and S. S. Tobe (2007). "The role of allatostatins in juvenile hormone synthesis in insects and crustaceans." Annu Rev Entomol 52: 277-299.

Steel, C. G. and X. Vafopoulou (2006). "Circadian orchestration of developmental hormones in the insect, Rhodnius prolixus." Comp Biochem Physiol A Mol Integr Physiol 144(3): 351-364.

Sterkel M, Riccillo FL, Ronderos JR (2010). Cardioacceleratory and myostimulatory activity of allatotropin in Triatoma infestans (Klüg). Comp Biochem Physiol A 155: 371-377.

Sterkel, M. (2011). Genómica y Proteómica de Neuropéptidos en Rhodnius prolixus. Phd., Universidad Nacional de Quilmes.

Sterkel, M., P. L. Oliveira, et al. (2012). "OKB, a novel family of brain-gut neuropeptides from insects." Insect Biochem Mol Biol 42(7): 466-473.

Sterkel, M., H. Urlaub, et al. (2011). "Functional proteomics of neuropeptidome dynamics during the feeding process of Rhodnius prolixus." J Proteome Res 10(8): 3363-3371.

Sugahara, R., S. Tanaka, et al. (2017). "Two types of albino mutants in desert and migratory locusts are caused by gene defects in the same signaling pathway." Gene 608: 41-48.

Suman, D. S., C. W. Brey, et al. (2013). "Effects of insect growth regulators on the mosquitoparasitic nematode Romanomermis iyengari." Parasitol Res 112(2): 817-824.

Suman, D. S., Y. Wang, et al. (2013). "Ovicidal activity of three insect growth regulators against Aedes and Culex mosquitoes." Acta Trop 128(1): 103-109.

T. Curtis, A., M. Hori, et al. (1984). Ecdysteroid regulation of the onset of cuticular melanization in allatectomized and Black mutant Manduca sexta larvae.

Talbot, W. S., E. A. Swyryd, et al. (1993). "Drosophila tissues with different metamorphic responses to ecdysone express different ecdysone receptor isoforms." Cell 73(7): 1323-1337.

Tanaka, Y., Y. Suetsugu, et al. (2014). "Transcriptome analysis of neuropeptides and G-protein coupled receptors (GPCRs) for neuropeptides in the brown planthopper Nilaparvata lugens." Peptides 53: 125-133.

Tanaka, Y. and F. Yukuhiro (1999). "Ecdysone has an effect on the regeneration of midgut epithelial cells that is distinct from 20-hydroxyecdysone in the silkworm Bombyx mori." Gen Comp Endocrinol 116(3): 382-395.

Tassone, E. E., S. M. Geib, et al. (2016). "De novo construction of an expanded transcriptome assembly for the western tarnished plant bug, Lygus hesperus." Gigascience 5: 6.

Te Brugge, V., J. P. Paluzzi, et al. (2011). "Identification of kinin-related peptides in the disease vector, Rhodnius prolixus." Peptides 32(3): 469-474.

Te Brugge, V. A., V. C. Lombardi, et al. (2005). "Presence and activity of a Dippu-DH31-like peptide in the blood-feeding bug, Rhodnius prolixus." Peptides 26(1): 29-42.

Te Brugge, V. A., S. M. Miksys, et al. (1999). "The distribution of a CRF-like diuretic peptide in the blood-feeding bug Rhodnius prolixus." J Exp Biol 202(Pt 15): 2017-2027.

Te Brugge, V. A., D. R. Nassel, et al. (2001). "The distribution of a kinin-like peptide and its colocalization with a CRF-like peptide in the blood-feeding bug, Rhodnius prolixus." Peptides 22(2): 161-173.

Te Brugge, V. A. and I. Orchard (2002). "Evidence for CRF-like and kinin-like peptides as neurohormones in the blood-feeding bug, Rhodnius prolixus." Peptides 23(11): 19671979.

Te Brugge, V. A. and I. Orchard (2008). "Distribution and activity of a Dippu DH31-like peptide in the large milkweed bug Oncopeltus fasciatus." Peptides 29(2): 206-213.

Thomson, W. T. (2001). Agricultural Chemicals, Book I, Insecticides. Fresno, California, Thomson Publications. 
Traverso, L., A. Lavore, et al. (2017). "Comparative and functional triatomine genomics reveals reductions and expansions in insecticide resistance-related gene families." PLoS Negl Trop Dis 11(2): e0005313.

Traverso, L., I. Sierra, et al. (2016). "Neuropeptidomics in Triatoma infestans. Comparative transcriptomic analysis among triatomines." J Physiol Paris 110(3 Pt A): 83-98.

Truman, J. W. (1973). "Physiology of Insect Ecdysis. Ii. The Assay and Occurrence of the Eclosion Hormone in the Chinese Oak, Silkmoth, Antheraea Pernyi." Biol Bull 144(1): 200-211.

Truman, J. W. (1992). "The eclosion hormone system of insects." Prog Brain Res 92: 361-374.

Truman, J. W. (2005). "Hormonal control of insect ecdysis: endocrine cascades for coordinating behavior with physiology." Vitam Horm 73: 1-30.

Truman, J. W. and S. E. Reiss (1988). "Hormonal regulation of the shape of identified motoneurons in the moth Manduca sexta." J Neurosci 8(3): 765-775.

Truman, J. W. and L. M. Riddiford (1970). "Neuroendocrine control of ecdysis in silkmoths." Science 167(3925): 1624-1626.

Tsukamoto, M. (1964). "Genetic Aspect of Insecticide Resistance in Insects." Jpn J Med Sci Biol 17: $53-54$.

Vafopoulou, X. and C. G. Steel (1989). "Developmental and diurnal changes in ecdysteroid biosynthesis by prothoracic glands of Rhodnius prolixus (Hemiptera) in vitro during the last larval instar." Gen Comp Endocrinol 74(3): 484-493.

Vafopoulou, X. and C. G. Steel (1996). "Circadian regulation of a daily rhythm of release of prothoracicotropic hormone from the brain retrocerebral complex of Rhodnius prolixus (hemiptera) during larval-adult development." Gen Comp Endocrinol 102(1): 123-129.

Vafopoulou, X. and C. G. Steel (2005). "Testis ecdysiotropic peptides in Rhodnius prolixus: biological activity and distribution in the nervous system and testis." $\mathrm{J}$ Insect Physiol 51(11): 1227-1239.

Vafopoulou, X. and C. G. Steel (2006). "Ecdysteroid hormone nuclear receptor (EcR) exhibits circadian cycling in certain tissues, but not others, during development in Rhodnius prolixus (Hemiptera)." Cell Tissue Res 323(3): 443-455.

Vafopoulou, X. and C. G. Steel (2012). "Cytoplasmic travels of the ecdysteroid receptor in target cells: pathways for both genomic and non-genomic actions." Front Endocrinol (Lausanne) 3: 43.

Vafopoulou, X. and C. G. Steel (2012). "Metamorphosis of a clock: remodeling of the circadian timing system in the brain of Rhodnius prolixus (Hemiptera) during larval-adult development." J Comp Neurol 520(6): 1146-1164.

Vafopoulou, X., C. G. Steel, et al. (2007). "Neuroanatomical relations of prothoracicotropic hormone neurons with the circadian timekeeping system in the brain of larval and adult Rhodnius prolixus (Hemiptera)." J Comp Neurol 503(4): 511-524.

Vafopoulou, X., K. L. Terry, et al. (2010). "The circadian timing system in the brain of the fifth larval instar of Rhodnius prolixus (hemiptera)." J Comp Neurol 518(8): 1264-1282.

Van Emden, H. R. H. (2007). Aphids As Crop Pests, Oxford University Press.

Veenstra, J. A. (1989). "Isolation and structure of corazonin, a cardioactive peptide from the American cockroach." FEBS Lett 250(2): 231-234.

Veenstra, J. A. and T. Ida (2014). "More Drosophila enteroendocrine peptides: Orcokinin B and the CCHamides 1 and 2." Cell Tissue Res 357(3): 607-621.

Veenstra, T. D., S. Martinovic, et al. (2000). "Proteome analysis using selective incorporation of isotopically labeled amino acids." J Am Soc Mass Spectrom 11(1): 78-82.

Verleyen, P., J. Huybrechts, et al. (2009). "SIFamide illustrates the rapid evolution in Arthropod neuropeptide research." Gen Comp Endocrinol 162(1): 27-35.

Verlinden, H. (2014). Receptors for Neuronal or Endocrine Signalling Molecules as Potential Targets for the Control of Insect Pests. Department of Animal Physiology and 
Neurobiology, Zoological Institute, K.U. Leuven, Leuven, Belgium, Molecular Developmental Physiology and Signal Transduction, .

Villalobos-Sambucaro, M. J., A. N. Lorenzo-Figueiras, et al. (2015). "Allatotropin modulates myostimulatory and cardioacceleratory activities in Rhodnius prolixus (Stal)." PLoS One 10(4): e0124131.

Villalobos-Sambucaro, M. J., F. L. Riccillo, et al. (2015). "Genomic and functional characterization of a methoprene-tolerant gene in the kissing-bug Rhodnius prolixus." Gen Comp Endocrinol 216: 1-8.

Villalobos-Sambucaro MJ, Lorenzo-Figueiras AN, Riccillo FL, Diambra LA, Noriega FG, Ronderos JR (2015) Allatotropin Modulates Myostimulatory and Cardioacceleratory Activities in Rhodnius prolixus (Stal). PLoS ONE 10(4): e0124131.

Vincent, J. (1972). The dynamics of release and the possible identity of bursicon in Locusta migratoria migratorioides.

Wang, J., M. Wu, et al. (2013). "Comparison of the RNA interference effects triggered by dsRNA and siRNA in Tribolium castaneum." Pest Manag Sci 69(7): 781-786.

Wang, S., J. Wang, et al. (2012). "PKC-mediated USP phosphorylation at Ser35 modulates 20hydroxyecdysone signaling in Drosophila." J Proteome Res 11(12): 6187-6196.

Wang, Z., I. Orchard, et al. (1995). "Mode of action of an inhibitory neuropeptide SchistoFLRFamide on the locust oviduct visceral muscle." Neuropeptides 28(3): 147155.

Watanabe, K., J. J. Hull, et al. (2007). "FXPRL-amide peptides induce ecdysteroidogenesis through a G-protein coupled receptor expressed in the prothoracic gland of Bombyx mori." Mol Cell Endocrinol 273(1-2): 51-58.

Waugh, D. S. (2011). "An overview of enzymatic reagents for the removal of affinity tags." Protein Expr Purif 80(2): 283-293.

Weaver, R. J. and N. Audsley (2009). "Neuropeptide regulators of juvenile hormone synthesis: structures, functions, distribution, and unanswered questions." Ann N Y Acad Sci 1163: 316-329.

Wegener, C. and A. Gorbashov (2008). "Molecular evolution of neuropeptides in the genus Drosophila." Genome Biol 9(8): R131.

Wessels, A. (2012). Farming in the 1950s \& 60s Living History Farm. York, Nebraska.

Wigglesworth, V. B. (1934). "The physiology of ecdysis in Rhodnius prolixus (Hemiptera). II. Factors controlling moulting and metamorphosis." Quarterly Journal of Microscopy Science 77(875): 191-222.

Wigglesworth, V. B. (1940). "Local and General Factors in the Development of \&quot;Pattern\&quot; in \&lt;em\&gt;Rhodnius Prolixus\&lt;/em\&gt; (Hemiptera)." Journal of Experimental Biology 17(2): 180.

WIGGLESWORTH, V. B. (1948). "The Functions of the Corpus Allatum in <em>Rhodnius Prolixus</em> (Hemiptera)." Journal of Experimental Biology 25(1): 1-15.

Wigglesworth, V. B. (1951). "Source of moulting hormone in Rhodnius." Nature 168(4274): 558.

Wigglesworth, V. B. (1964). "Homeostasis in insect growth." Symp Soc Exp Biol 18: 265-281.

Wilson, R. (2010). P. J. Gullan and P. S. Cranston: The insects: an outline of entomology (4th edition).

Woodward (2012). Toxicological Effects of Veterinary Medicinal Products in Humans, Royal Society of Chemistry.

Wu-Smart, J. and M. Spivak (2016). "Sub-lethal effects of dietary neonicotinoid insecticide exposure on honey bee queen fecundity and colony development." Sci Rep 6: 32108.

Wulff, J. P., I. Sierra, et al. (2017). "Orcokinin neuropeptides regulate ecdysis in the hemimetabolous insect Rhodnius prolixus." Insect Biochem Mol Biol 81: 91-102.

Yamanaka, N., Y. J. Hua, et al. (2005). "Identification of a novel prothoracicostatic hormone

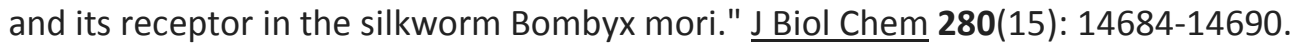


Yamanaka, N., L. Roller, et al. (2011). "Bombyx orcokinins are brain-gut peptides involved in the neuronal regulation of ecdysteroidogenesis." J Comp Neurol 519(2): 238-246.

Yamanaka, N., S. Yamamoto, et al. (2008). "Neuropeptide receptor transcriptome reveals unidentified neuroendocrine pathways." PLoS One 3(8): e3048.

Young, F. M., M. F. Menadue, et al. (2005). "Effects of the insecticide amitraz, an alpha2adrenergic receptor agonist, on human luteinized granulosa cells." 20(11): 3018-3025.

Zalucki, M. P. and M. J. Furlong (2017). "Behavior as a mechanism of insecticide resistance: evaluation of the evidence." Curr Opin Insect Sci 21: 19-25.

Zandawala, M., A. S. Haddad, et al. (2015). "Identification and characterization of the adipokinetic hormone/corazonin-related peptide signaling system in Rhodnius prolixus." FEBS J 282(18): 3603-3617.

Zandawala, M., Y. Lytvyn, et al. (2012). "Cloning of the cDNA, localization, and physiological effects of FGLamide-related allatostatins in the blood-gorging bug, Rhodnius prolixus." Insect Biochem Mol Biol 42(1): 10-21.

Zandawala, M. and I. Orchard (2015). "Identification and functional characterization of FGLamide-related allatostatin receptor in Rhodnius prolixus." Insect Biochem Mol Biol 57: $1-10$

Zels, S., S. Dillen, et al. (2015). "Sulfakinin is an important regulator of digestive processes in the migratory locust, Locusta migratoria." Insect Biochem Mol Biol 61: 8-16.

Zhao, R., X. Yu, et al. (2001). "Study on the degeneracy of antisense peptides using affinity chromatography." J Chromatogr A 913(1-2): 421-428.

Zhao, X., K. Mita, et al. (2001). "Isolation and expression of an ecdysteroid-inducible neutral endopeptidase 24.11-like gene in wing discs of Bombyx mori." Insect Biochem Mol Biol 31(12): 1213-1219.

Zhou, B., K. Hiruma, et al. (1998). "Regulation of the transcription factor E75 by 20hydroxyecdysone and juvenile hormone in the epidermis of the tobacco hornworm, Manduca sexta, during larval molting and metamorphosis." Dev Biol 193(2): 127-138.

Zilberstein, Y., J. Ewer, et al. (2006). "Neuromodulation of the locust frontal ganglion during the moult: a novel role for insect ecdysis peptides." J Exp Biol 209(Pt 15): 2911-2919.

Zitnan, D. (1989). "Stomogastric nervous system of Galleria Mellonella L (Lepdoptera: Pyralidae); changes during metamorphosis with special reference to FMRFamide neurons." Int. J. Insect. Morphol. Embryol. 18: 227-237.

Zitnan, D. (2012). Neuroendocrine regulation of ecdysis. Insect Endocrinology. L. I. Gilbert. London, Academic Press: 253-309.

Zitnan, D. and M. E. Adams (2000). "Excitatory and inhibitory roles of central ganglia in initiation of the insect ecdysis behavioural sequence." J Exp Biol 203(Pt 8): 1329-1340.

Zitnan, D., L. Hollar, et al. (2002). "Molecular cloning and function of ecdysis-triggering hormones in the silkworm Bombyx mori." J Exp Biol 205(Pt 22): 3459-3473.

Zitnan, D., Y. J. Kim, et al. (2007). "Complex steroid-peptide-receptor cascade controls insect ecdysis." Gen Comp Endocrinol 153(1-3): 88-96.

Zitnan, D., T. G. Kingan, et al. (1996). "Identification of ecdysis-triggering hormone from an epitracheal endocrine system." Science 271(5245): 88-91.

Zitnan, D., L. S. Ross, et al. (1999). "Steroid induction of a peptide hormone gene leads to orchestration of a defined behavioral sequence." Neuron 23(3): 523-535.

Zitnan, D., I. Zitnanova, et al. (2003). "Conservation of ecdysis-triggering hormone signalling in insects." J Exp Biol 206(Pt 8): 1275-1289.

Zitnanova, I., M. E. Adams, et al. (2001). "Dual ecdysteroid action on the epitracheal glands and central nervous system preceding ecdysis of Manduca sexta." J Exp Biol 204(Pt 20): 3483-3495.

Zlotkin, E. (1999). "The insect voltage-gated sodium channel as target of insecticides." Annu Rev Entomol 44: 429-455. 


\section{ANEXO}

\section{Primers}

\begin{tabular}{|c|c|}
\hline PCR_OKA/B Fwd & ATCAACATGCTGTCGT \\
\hline PCR_OKC Fwd & TGCGGCTAGAGTTAGGA \\
\hline PCR_OKC Rev & TGACATATTTAAAAGCGCAGCA \\
\hline RhoprACTIN Fwd & ACACCCAGTTTTGCTTACGG \\
\hline RhoprACTIN Rev & GTTCGGCTGTGGTGATGA \\
\hline GeneRacer 3' Primer ${ }^{\circledR}$ & GCTGTCAACGATACGCTACGTAACG \\
\hline GeneRacer 3'Nested Primer ${ }^{\circledR}$ & CGCTACGTAACGGCATGACAGTG \\
\hline OKS-RNAi Fwd & TAATACGACTCACTATAGGGTCACTATCGCTGCGTCTCTGT \\
\hline OKS-RNAi Rev & TAATACGACTCACTATAGGGCTAAAGTATCCAAATTTCGGCCCTC \\
\hline AMP-RNAi Fwd & TAATACGACTCACTATAGGGGAACTGGATCTCAACAG \\
\hline AMP-RNAi Rev & TAATACGACTCACTATAGGGGGATCTTCACCTAGATC \\
\hline dsOKA Fwd & TAATACGACTCACTATAGGGGAAGCGGTTTTGATGGTTTTGT \\
\hline dsOKA Rev & TAATACGACTCACTATAGGGGGGATTCTTTGCATAAATGGTCA \\
\hline dsOKB Fwd & TAATACGACTCACTATAGGGTAGACGGTGTTATCGTAGAG \\
\hline $\mathrm{dsOKB} / \mathrm{C} \operatorname{Rev}$ & TAATACGACTCACTATAGGGAATGACCTCCACCCAAACCAT \\
\hline dsRhoprETH Fwd & TAATACGACTCACTATAGGGGCTGCTGATGGTAGAAGTGG \\
\hline dsRhoprETH Rev & TAATACGACTCACTATAGGGTACAGCAATGGAACTTCGCC \\
\hline dsRhoprEH Fwd & TAATACGACTCACTATAGGGTGAAGAAGCTGCTGTTGGTG \\
\hline dsRhoprEH Rev & TAATACGACTCACTATAGGGAGAAATGGTCCAATTGAGGCA \\
\hline dsRhoprCZ Fwd & TAATACGACTCACTATAGGGTGCCCTTTACTAGACAGGGG \\
\hline dsRhoprCZ Rev & TAATACGACTCACTATAGGGCCTGTGGTATAGTCTTTCCTTCA \\
\hline T7 full & ATAGAATTCTCTCTAGAAGCTTAATACGACTCACTATAGGG \\
\hline qPCR RpEF1 Fwd & GATTCCACTGAACCGCCTTA \\
\hline qPCR RpEF1 Rev & GCCGGGTTATATCCGATTTT \\
\hline qPCR TUB Fwd & TGTGCCCAAGGATGTGAACG \\
\hline qPCR TUB Rev & CACAGTGGGTGGTTGGTAGTTGAT \\
\hline qPCR OKA Fwd & TGCCGCAGACAAACGTAATT \\
\hline qPCR OKA Rev & ACAAAACCATCAAAACCGCTTC \\
\hline qPCR OKB Fwd & GAGCGAAATTATGGACCAGCA \\
\hline qPCR OKB Rev & ATGACCTCCACCCAAACCAT \\
\hline qPCR_E75a Fwd & AGAGGGAGTCAATACATAGTGGA \\
\hline
\end{tabular}




\begin{tabular}{|l|l|}
\hline qPCR_E75a Rev & AATCTCCGGATCTGTCAGCC \\
\hline qPCR_Disembodied Fwd & ATGGTGGCGTTTGAGGAGTA \\
\hline qPCR_Disembodied Rev & TCTTGTCGGATGAAGGCAGA \\
\hline qPCR_RhoprETH Rev & GCAGAGATGAGTTCCACGAG \\
\hline qPCR_RhoprEH Fwd & GTGATCCGCTGAACTGTCAC \\
\hline qPCR_RhoprEH Rev & TGTGCCCAGTGTAAGAAAATGT \\
\hline qPCR_RhoprCZ Fwd & TGTCCTCACAGTCTGGAATCA \\
\hline qPCR_RhoprCZ Rev & TGCCCTTTACTAGACAGGGG \\
\hline qPCR_RhoprCCAP Fwd & CTGAAATGTTTGGCCAAAGACA \\
\hline qPCR_RhoprCCAP Rev & CTGCAAAAAAGGCTTTATTTTCC \\
\hline qPCR_RhoprEsplmB Fwd & TCCCATAACTTCGCTTCAGAC \\
\hline qPCR_RhoprEsplmB Rev & GCCACATTTTCACCTTCGCT \\
\hline qPCR_RhoprJH-MET Fwd & ATGCGTGCTTAAAGAGATGGT \\
\hline qPCR_RhoprJH-MET Rev & TAACATCGCCTGGTCCTGAA \\
\hline
\end{tabular}

\section{Síntesis de cDNA}

- Se trató $1 \mu \mathrm{g}$ de RNA con: $0,5 \mu \mathrm{ls}$ de DNAsa 1 (Thermo Fisher Scientific ${ }^{\circledR}$ ), $0,5 \mu 1 \mathrm{~s}$ de inhibidor de RNAsa (Ribolock Thermo Fisher Scientific ${ }^{\circledR}$ ) y $1 \mu 1$ de buffer 10x de la enzima DNAsa 1. Se colocó en un baño térmico (Lauda ${ }^{\circledR}$ ) durante 30 minutos a $37^{\circ} \mathrm{C}$.

- Se agregó $1 \mu 1$ de EDTA 50mM y colocó en el baño durante 10 min a $65^{\circ} \mathrm{C}$ para desactivar la actividad DNAsa de la enzima.

- Se agregó $1 \mu \mathrm{l}$ de primer Oligodt (primer poliT) concentración $100 \mu \mathrm{M}$ y se colocó en baño 5 min a $70^{\circ} \mathrm{C}$. Cinco min finales en hielo.

- Se agregó a la muestra la mix de la enzima M-MLV (ver abajo) preparada con anterioridad. Se colocó en baño durante 120 min a $42^{\circ} \mathrm{C}$.

- Se colocó $5 \mathrm{~min}$. en baño a $85^{\circ} \mathrm{C}$ y posteriormente $5 \mathrm{~min}$. en hielo. Se conservó a $-20^{\circ} \mathrm{C}$ hasta su uso. 
Mix M-MLV:

\begin{tabular}{lc}
\hline M-MLV buffer mix & $5,0 \mu \mathrm{ls}$ \\
\hline Mix dNTPs 10mM (A, T, C, G) & $2,5 \mu \mathrm{ls}$ \\
\multicolumn{3}{l}{ Inhibidor de RNAsas (Thermo Fisher $_{\left.\text {Scientific }^{\circledR}\right)}$} & $0,5 \mu \mathrm{ls}$ \\
M-MLV & $0,5 \mu \mathrm{ls}$ \\
$\mathrm{H}_{2} \mathrm{O}$ libre de RNAsas & $4,5 \mu \mathrm{ls}$ \\
\hline
\end{tabular}

3. Protocolo PCR

3.1. Mix PCR

\begin{tabular}{|c|c|c|}
\hline Mix & oncentración Final & \\
\hline $\mathrm{MgCl}_{2}$ & $2,5 \mathrm{mM}$ & \\
\hline Taq. Pegasus buffer & $\mathbf{1 X}$ & \\
\hline Mix dNTPs 10mM (A, T, C, G) & $0,25 \mathrm{mM}$ & \\
\hline Primers & $0,25 \mu \mathrm{M}(\mathrm{c} / \mathrm{u})$ & \\
\hline Molde cDNA & 25-50ngs & \\
\hline Taq Pegasus ${ }^{\circledR}$ & 2 un & \\
\hline $\begin{array}{l}\mathrm{H}_{2} \mathrm{O} \\
20 \mu \mathrm{ls} .\end{array}$ & a llevar a volumen & Volumen final \\
\hline
\end{tabular}

\subsection{Programa PCR}

\begin{tabular}{lll}
\hline Temperatura & Tiempo & Ciclos \\
\hline $95^{\circ} \mathrm{C}$ & $5 \mathrm{~min}$. & $1 \mathrm{Ciclo}$ \\
$94^{\circ} \mathrm{C}$ & $15 \mathrm{seg}$. & \\
Primer Ann. & $15 \mathrm{seg}$. & 35 Ciclos \\
$7^{\circ} \mathrm{C}$ (Elongación) & Dependiente $\mathrm{N}^{\circ}$ de bases & \\
\hline
\end{tabular}




\section{Protocolo qPCR}

\subsection{Mix qPCR}

\begin{tabular}{lcc}
\hline Mix & \multicolumn{2}{c}{ Concentración Final } \\
\hline Fast Start SYBR Green Master ${ }^{\circledR}$ & (Roche) & $1 \mathrm{X}$ \\
Primers & $0,25 \mu \mathrm{M}$ & \\
$\mathrm{H}_{2} \mathrm{O}$ & Hasta llevar a volumen & \\
& & Volumen final $15 \mu \mathrm{ls}$. \\
\hline
\end{tabular}

\subsection{Programa qPCR}

\begin{tabular}{llc}
\hline Temperatura & Tiempo & Ciclos \\
\hline $95^{\circ} \mathrm{C}$ & $5 \mathrm{~min}$. & 1 Ciclo \\
$95^{\circ} \mathrm{C}$ & $30 \mathrm{seg}$. & \\
$60^{\circ} \mathrm{C}$ & $30 \mathrm{seg}$. & 39 Ciclos \\
$72^{\circ} \mathrm{C}$ (Elongación) & $30 \mathrm{seg}$. & $1 \mathrm{Ciclo}$ \\
$72^{\circ} \mathrm{C}$ (Elongación Final) & $10 \mathrm{~min}$. & \\
Curva de melting & $65^{\circ} \mathrm{C}-9^{\circ} \mathrm{C}$ incrementando $1^{\circ} \mathrm{C}$ cada 0,05 seg. \\
\hline
\end{tabular}

5. Electroforesis en gel de agarosa

- Se agregó en un erlenmeyer de $150 \mathrm{~mL}$ : 1 gr de agarosa y $100 \mathrm{~mL}$ de buffer $(1 \%$ $\mathrm{m} / \mathrm{v})$ Tris-EDTA PH 8 1X (10mM Tris-HCl, 1mM disodio EDTA, ver protocolo en: anexo, soluciones).

- Se calentó por 3 min. en horno de microondas y se volcó sobre una cama de acrílico dispuesta en la parte superior con un "peine" de acrílico a fin de conformar los pocillos de siembra de la muestra. 
- Se dejó enfriar por 15 min., se desmontó y colocó en una cuba de electroforesis.

- Se sembraron las muestras mezcladas con buffer de siembra en paralelo con un marcador de peso molecular de 100pb (Embiotec ${ }^{\circledR}$ ) (posee bandas de diferentes pesos moleculares entre 100pb y 2000pb). Las muestras se mezclaron con buffer.

- Se procedió a la corrida electroforética durante 30-40 min. a $100 \mathrm{mV}$ y amperaje constante.

Se visualizaron las bandas en un transiluminador de luz ultravioleta acoplado a una cámara fotográfica digital $\left(\mathrm{CANON}^{\mathrm{TM}}\right.$ Eos Rebel) y una computadora. Se tomaron fotos de los geles. Se visualizaron y cuantificaron con el programa ImageJ2x.

\section{Elusión de ADN del gel de agarosa}

- Se cortó el rectángulo de gel que contenía el ADN de interés con una hoja tipo Gillette y se colocó en una columna de recolección del kit de extracción $\left(\right.$ QUIAGEN $\left.^{\mathrm{TM}}\right)$.

- Se agregaron $100 \mu 1 \mathrm{~s}$ de buffer por cada $100 \mathrm{mg}$ de gel.

- Se añadieron 3-5 volúmenes de buffer QG por cada volumen de gel para disolverlo.

- Se incubó por $10 \mathrm{~min}$ a $50^{\circ} \mathrm{C}$, agitando cada 2 minutos.

- Se añadió un volumen de Isopropanol y agitar se agitó suavemente.

- Se colocó la columna de recolección dentro de la columna de descarte y centrifugó a máxima velocidad durante 1 min.

- Se descartó el buffer y se agregaron $750 \mu$ ls de buffer de lavado PE Se centrifugó a máxima velocidad durante $1 \mathrm{~min}$.

- Se descartó el buffer y re centrifugó en las mismas condiciones. 
- Se colocó la columna dentro de un tubo eppendorf estéril. Se añadieron $20 \mu 1 \mathrm{~s}$ de buffer de elución EB (PH 8) sobre la membrana dentro de la columna de recolección. Después de 1 min se centrifugó por 2 min a máxima velocidad.

- Se guardó a $-80^{\circ} \mathrm{C}$ hasta su uso.

\section{Precipitación etanólica}

- Se añadió a la muestra 0,1 volúmenes de acetato de sodio $3 \mathrm{M}$ y 2,5 volúmenes de etanol absoluto.

- Se agitó por vortex tres segundos.

- Se mantuvo a $-20^{\circ} \mathrm{C}$ durante toda la noche.

- Se centrifugó a temperatura ambiente durante 20 minutos.

- Se lavó el precipitado con $1 \mathrm{~mL}$ de etanol $75 \%$.

- Se descartó el etanol por inversión del tubo y luego suavemente con ayuda de una micro-pipeta.

- Se colocó por $5 \min$ a $37^{\circ} \mathrm{C}$.

- Se resuspendió el precipitado en $20 \mu 1$ de agua MilliQ o solución salina (para inyecciones in vivo) y se mantuvo a $-20^{\circ} \mathrm{C}$ el ARNdc y a $-80^{\circ} \mathrm{C}$ sin es ARNsc.

\section{Extracción fenol-cloroformo}

- Se agregó a la muestra 0,5 volúmenes de Fenol PH 4 y 0,5 volúmenes de cloroformo.

- Se agitó fuertemente por 15 segundos.

- Se centrifugó a temperatura ambiente por $5 \mathrm{~min}$. 
- Se recuperó la fase acuosa (superior) y se colocó en un tubo nuevo.

- Se procedió a la precipitación etanólica de la muestra (ver arriba).

\section{Protocolo de inmunohistoquímica}

- Se disecaron los tejidos (ver arriba) y se fijaron en 2\% para-formaldehído (PFA) PH 7 durante toda la noche

- Se retiró el PFA y se enjuagó con buffer fosfato (PBS) PH 7.

- Se mantuvieron los tejidos en $200 \mu$ ls de una solución de PBS con: $4 \%$ de Triton $\mathrm{X}-100 ; 2 \%$ de sero-albúmina bovina (BSA) y suero normal de cabra (NGS) $10 \%$.

- Se realizaron tres lavados de 10 min. con $200 \mu 1$ de PBS.

- Se retiró el PBS y se incubó $48 \mathrm{hs} \mathrm{a} 4^{\circ} \mathrm{C}$ con el anticuerpo primario diluido en PBS con $0,4 \%$ de Triton X-100; $2 \%$ de BSA y $2 \%$ NGS. El anticuerpo $1^{\circ}$ se pre-incuba en la solución a $4^{\circ} \mathrm{C}$ por toda la noche. El antisuero anti OKA se diluyó 1:5000 y el anti OKB 1:3000. .

- Se retiró el anticuerpo $1^{\circ}$ y se incubó toda la noche en PBS.

- Se realizaron tres lavados de 10 min. con $200 \mu 1$ de PBS.

- Se retiró el PBS y se incubó toda la noche a $4^{\circ} \mathrm{C}$ con el anticuerpo $2^{\circ} \mathrm{Cy} 3$ (Santa Cruz Biotechnology, Dallas, USA) (concentración 1:500), preparado en una solución de PBS con 10\% de NSG.

- Se retiró el anticuerpo $2^{\circ}$ y se hicieron 5 lavados de 10 min. con $200 \mu 1$ de PBS.

- Se retiró el PBS y se montaron los tejidos en porta objetos de vidrio bajo lupa binocular con glicerol. Se guardaron los preparados $4^{\circ}-8^{\circ} \mathrm{C}$ en oscuridad.

Las muestras fueron observadas y las imágenes tomadas en un microscopio confocal Zeiss LSM 510 meta. 


\section{Transcripción reversa y síntesis de ARNdc}

- Se realizó una PCR de 35 ciclos utilizando los primers específicos (ver anexo, Primers) para la secuencia del gen elegido a silenciar. Estos primers adicionan a la secuencia original una secuencia complementaria al primer T7 full.

- Una vez confirmada la amplificación del fragmento correcto por electroforesis en gel de agarosa $1 \%$ se realizó una segunda PCR bajo las mismas condiciones, pero utilizando el primer T7 full (ver anexo, Primers), y 1ul de la PCR anterior como molde. Este primer aportan a la secuencia target el promotor de la polimerasa T7. Este paso fue repetido hasta conseguir la cantidad de ADN necesaria para la síntesis de ARNdc. El producto de las PCRs se precipitó (ver precipitación etanólica) y se resuspendió en $15 \mu 1 \mathrm{~s}$.

- Se preparó la mezcla de reacción en un tubo eppendorf de $1,5 \mathrm{~mL}$ con tapa a rosca (ver abajo, Mix T7 RNA polimerasa). Esta mezcla dentro del tubo fue colocada toda la noche a $37^{\circ} \mathrm{C}$.

- El tubo fue colocado en un flotador dentro de un vaso de precipitado de vidrio de $200 \mathrm{~mL}$. El vaso conteniendo el tubo fue puesto en un baño térmico a $95^{\circ} \mathrm{C}$ durante 10 minutos.

- Se retiró el vaso de precipitado del baño con el tubo dentro y se dejó reposar el vaso sobre la mesada hasta que alcanzó la temperatura ambiente. Este paso permite la formación paulatina de la doble hebra de ARN.

- El ARNdc fue tratado con 0,5 $\mu$ ls de DNAsa 1 (Thermo Fisher Scientific ${ }^{\circledR}$ ), RNAsa A (Thermo Fisher Scientific ${ }^{\circledR}, 5 \mu \mathrm{ls}$ en $1000 \mu \mathrm{ls}$ de reacción), a $37^{\circ} \mathrm{C}$ durante $30 \mathrm{~min}$. Posteriormente se realizó una extracción fenol-cloroformo (ver anexo, Extracción fenol-cloroformo) para eliminar las enzimas de la muestra.

- El ARNdc obtenido después de la extracción y precipitación etanólica se resuspendió en el volumen deseado para el ensayo, en solución salina de $R$. prolixus $\left(\mathrm{NaCl}, 129 \mathrm{mM}\right.$; KCl, $8.6 \mathrm{mM} ; \mathrm{CaCl}_{2} 2.0 \mathrm{mM} ; \mathrm{MgCl}_{2} 8.5 \mathrm{mM}$; $\mathrm{NaH}_{2} \mathrm{CO}_{3} 10.2 \mathrm{mM} ; \mathrm{NaH}_{2} \mathrm{PO}_{4} 4.3 \mathrm{mM}$; Hepes $8.6 \mathrm{mM}$, PH 7 (Te Brugge, Paluzzi et al. 2011). Se conservó a $-80^{\circ} \mathrm{C}$ hasta el momento de inyección. 


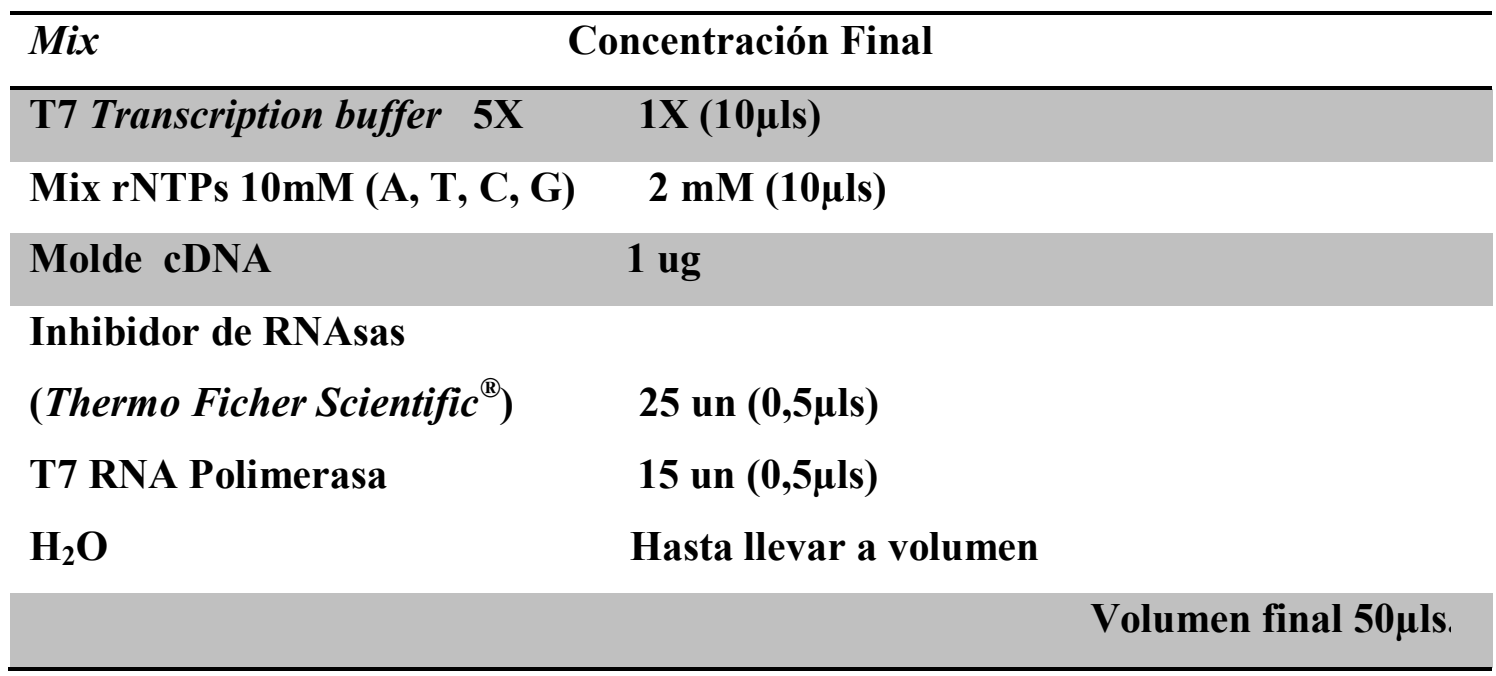

\section{ELISA Competitivo (EIA)}

\subsection{Procesamiento de las muestras}

- Por cada insecto se colectaron $5 \mu 1 \mathrm{~s}$ de hemolinfa en $95 \mu 1 \mathrm{~s}$ de metanol frío, mediante el corte de una pata.

- Se centrifugó por 5 min. a 13.200 rpm. El sobrenadante se conservó en un tubo estéril de $1,5 \mathrm{~mL}$.

- Se agregaron $100 \mu 1 \mathrm{~s}$ de metanol frío al precipitado obtenido, agitación fuerte por vortex por15 seg. y centrifugación por $5 \mathrm{~min}$. Se recuperó el sobrenadante y se juntó con el volumen recuperado en la primera extracción. Este paso se repitió una tercera vez.

- Las muestras fueron deshidratadas bajo alto vacío y guardadas a $-80^{\circ} \mathrm{C}$ hasta el momento de la medición. 


\subsection{EIA}

- Se resuspendió cada muestra en $100 \mu$ ls de buffer EIA (buffer fosfato 0,1M PH 7,4). Se sembraron en la placa (En la Figura 3 se muestra un esquema de la placa) $50 \mu 1 \mathrm{~s}$ de muestra por pocillo.

- Se agregaron $100 \mu 1 \mathrm{ls}$ de buffer EIA a los pocillos NBS y $50 \mu 1 \mathrm{ls}$ a los $\mathrm{B}_{0}$ (Figura $3)$.

- Se agregaron $50 \mu 1$ de buffer EIA a los pocillos de los estándares de la curva y a las muestras. Los estándares de la curva comprenden 8 diluciones seriadas de 20E (Sigma, Aldrich) sintético en un rango de concentración entre $1028 \mathrm{M} \mathrm{y}$ 10212M.

- Se agregaron $50 \mu 1 \mathrm{ls}$ de tracer (resuspendido en $6 \mathrm{~mL}$ de buffer EIA, es un conjugado de Peroxidasa y 2-succinil-20E) a todos los pocillos, excepto a los blanco (Blk) y actividad total (TA) (ver esquema placa).

- Se agregaron $50 \mu 1 \mathrm{~s}$ de anticuerpo policlonal contra ecdisteroides totales desarrollado en conejo resuspendido en $6 \mathrm{~mL}$ de buffer EIA,) excepto a los pocillos Blk, TA y NBS.

- Se incubó toda la noche a $4^{\circ} \mathrm{C}$.

- Se lavó 5 veces con buffer de lavado $\left(\mathrm{PBS}\left(\mathrm{Na}_{2} \mathrm{HPO}_{4}\right)+1 \%\right.$ Tween 20$)$.

- Se añadieron $200 \mu$ ls de reactivo de Ellmans a todos los pocillos.

- Se añadieron 5uls de tracer a los pocillos TA.

- Se incubó entre 90 y 120 minutos (hasta que $\mathrm{B}_{0}$ llegó entre 0,3 y 0,8 unidades de absorbancia) y se midió absorbancia con un lector de microplacas a $405 \mathrm{~nm}$. 


$$
\begin{aligned}
& \begin{array}{llllll}
1 & 2 & 3 & 4 & \cdots & n
\end{array} \\
& A \text { Bil)(S1)(11) } \star
\end{aligned}
$$

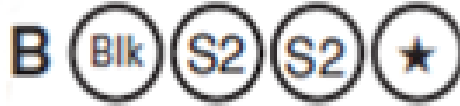

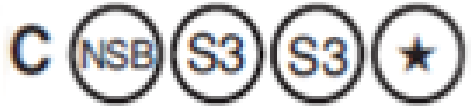

$$
\begin{aligned}
& \text { D (NSB) (S4) (S4) } \star \text { Muestras } \\
& \mathrm{E} \text { (8) (55) } \star 55 \\
& F \text { B } 36 \text { (56) } \star \\
& G \text { B. (57) (57) } \star \\
& \text { H (TA) (58) (58) } \star
\end{aligned}
$$

Figura 3: Esquema de la Placa: Blk: blanco; $\mathrm{B}_{0}$ : máxima unión; TA: actividad total; S1-8: estándares curva; $\star$ : muestras.

Las mediciones se realizaron en placas tipo Nunc MaxiSorp de EIA Cayman Chemical's $A C E^{\circledR}$ de 96 pocillos, con un equipo BertholdTech Mithras ${ }^{\circledR}$ Driver Version: 1.06, y un software de procesamiento MikroWin ${ }^{\circledR}$, versión 4.41. Los resultados fueron determinados por comparación con la curva estándar. Los valores obtenidos fueron expresados como equivalentes de 20E, previa transformación logarítmica. El anticuerpo y el tracer fueron donados gentilmente por el Dr. Reggi (Marsella, Francia) y el Dr. Delbecque (Bordeaux, Francia). Las mediciones se realizaron en el laboratorio dirigido por el Dr. Jozef Vanden Broeck en el Depto. De Zoología. Universidad Católica de Leuven (KUL), Bélgica. 


\subsection{Secuencia OKs y sitio de unión de primers RNAi por isoforma}

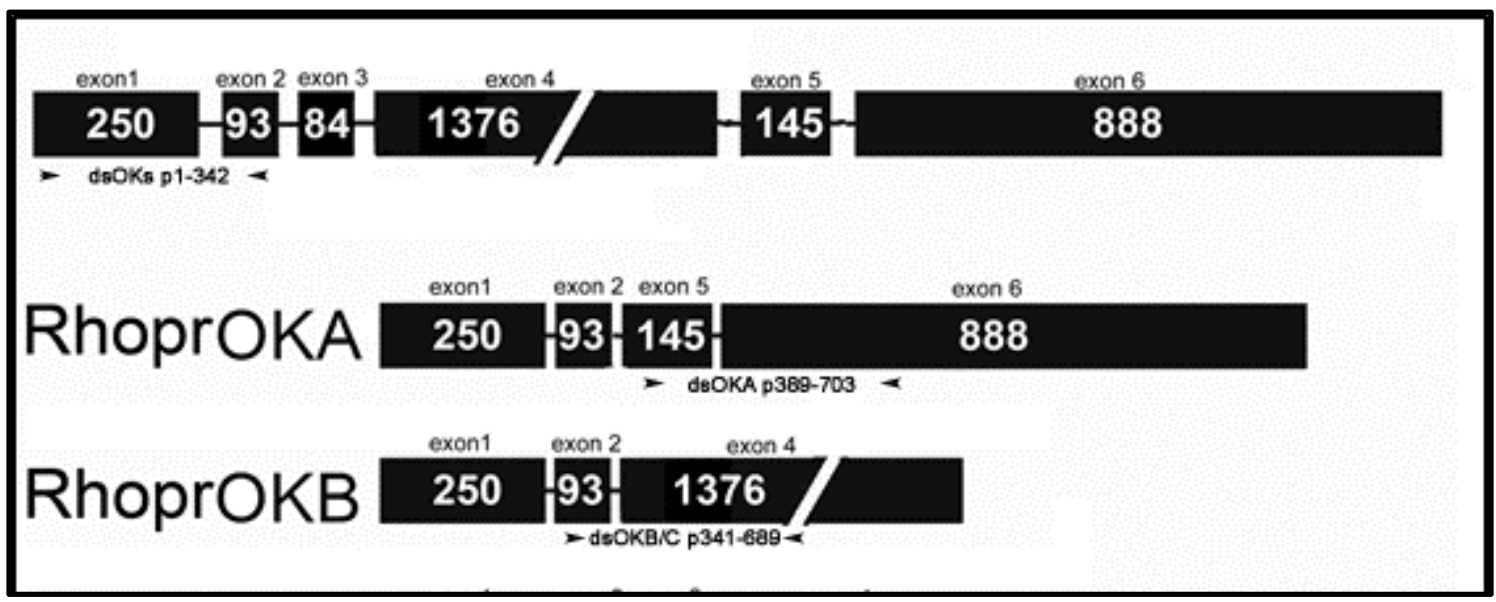

Figura 4: Estructura del gen precursor de orcokinina y las variantes de splicing OKA y OKB. Las líneas representan los intrones y los números la cantidad de bases por exón. Se detalla las secuencias amplificadas para el silenciamiento transcripcional del gen completo (dsOKS) y los silenciamientos por isoforma (dsOKA y dsOKB), como así las posiciones en número de nucleótidos de inicio y finalización de cada amplicon.

\subsection{Secuencia hormona desencadenante de la muda (ETH)}

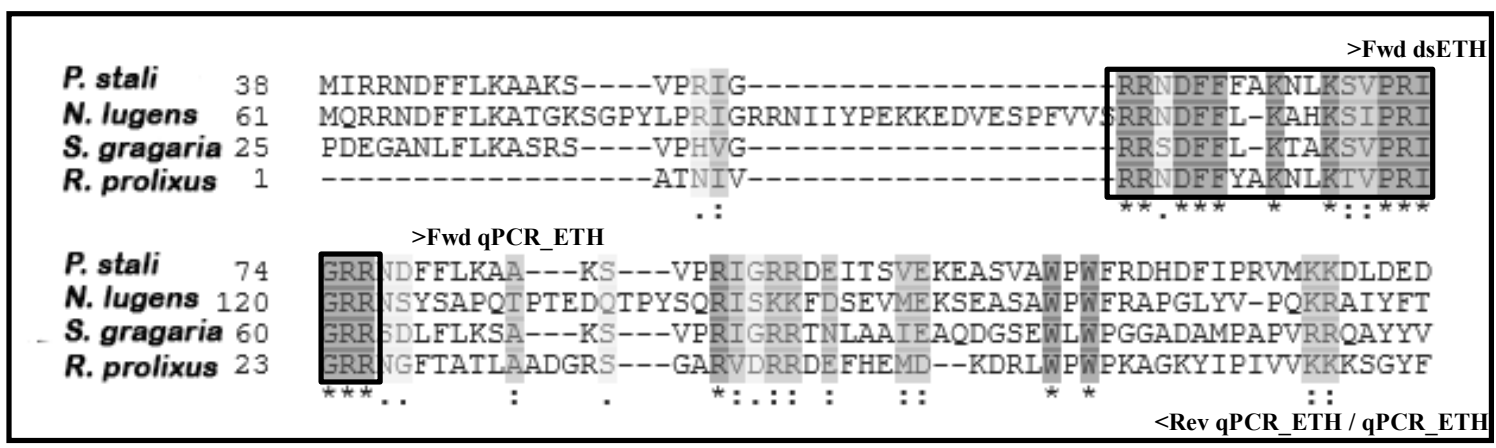

Figura 5: Secuencia aminoacídica del neuropéptido desencadenante de la muda en diferentes insectos hemípteros y ubicación de los primers utilizados. Se encuentra recuadrado en negro la secuencia aminoacídica del péptido maduro cuya secuencia es la más conservada entre distintos insectos. 


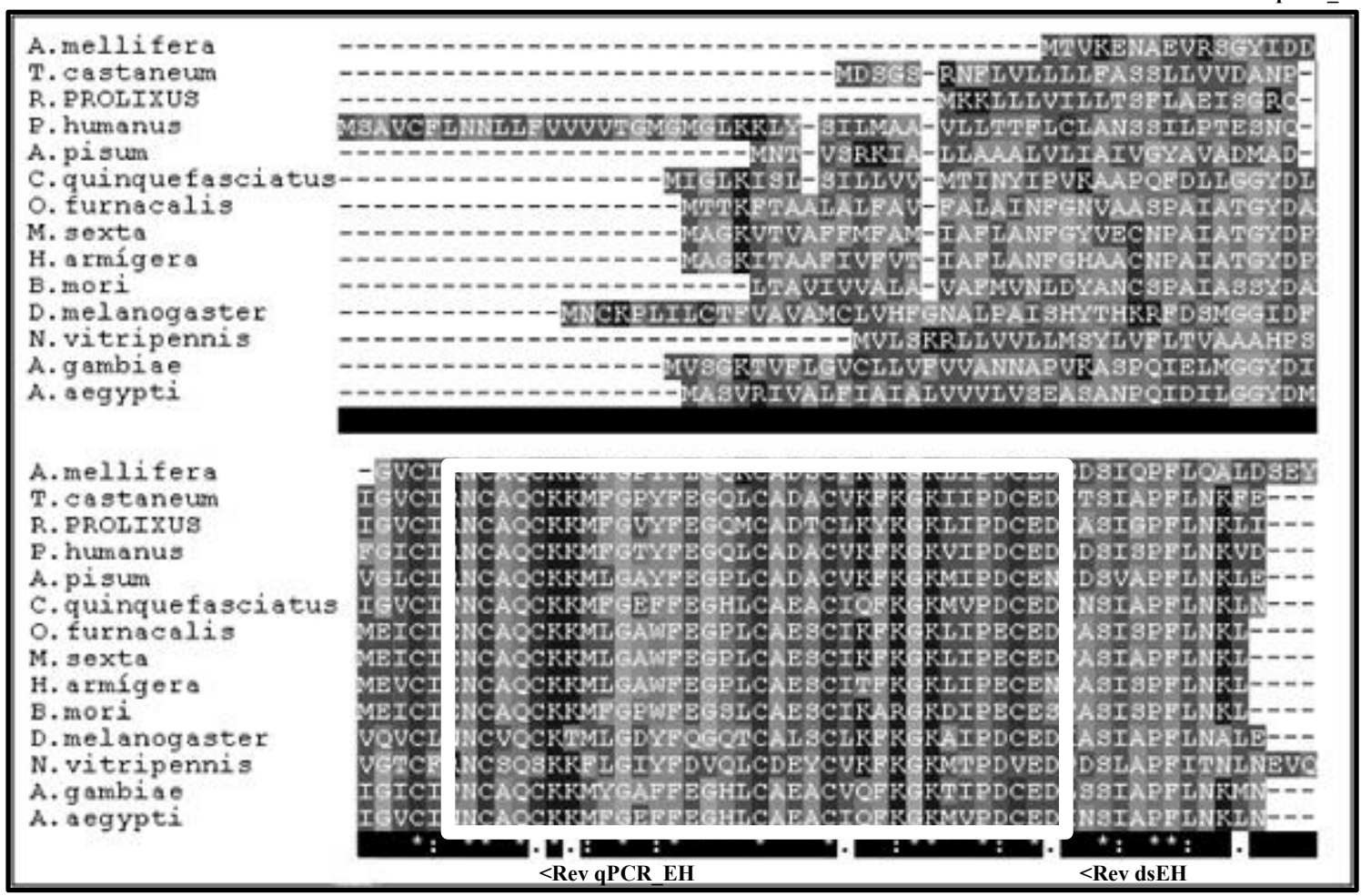

Figura 6: Secuencia aminoacídica del neuropéptido de la Eclosión en diferentes insectos (Ons, Richter et al. 2009; Sterkel 2011) y ubicación de los primers utilizados. Se encuentra recuadrado en blanco la secuencia aminoacídica del péptido maduro cuya secuencia es la más conservada entre distintos insectos.

\subsection{Secuencia corazonina $(\mathrm{CZ})$}

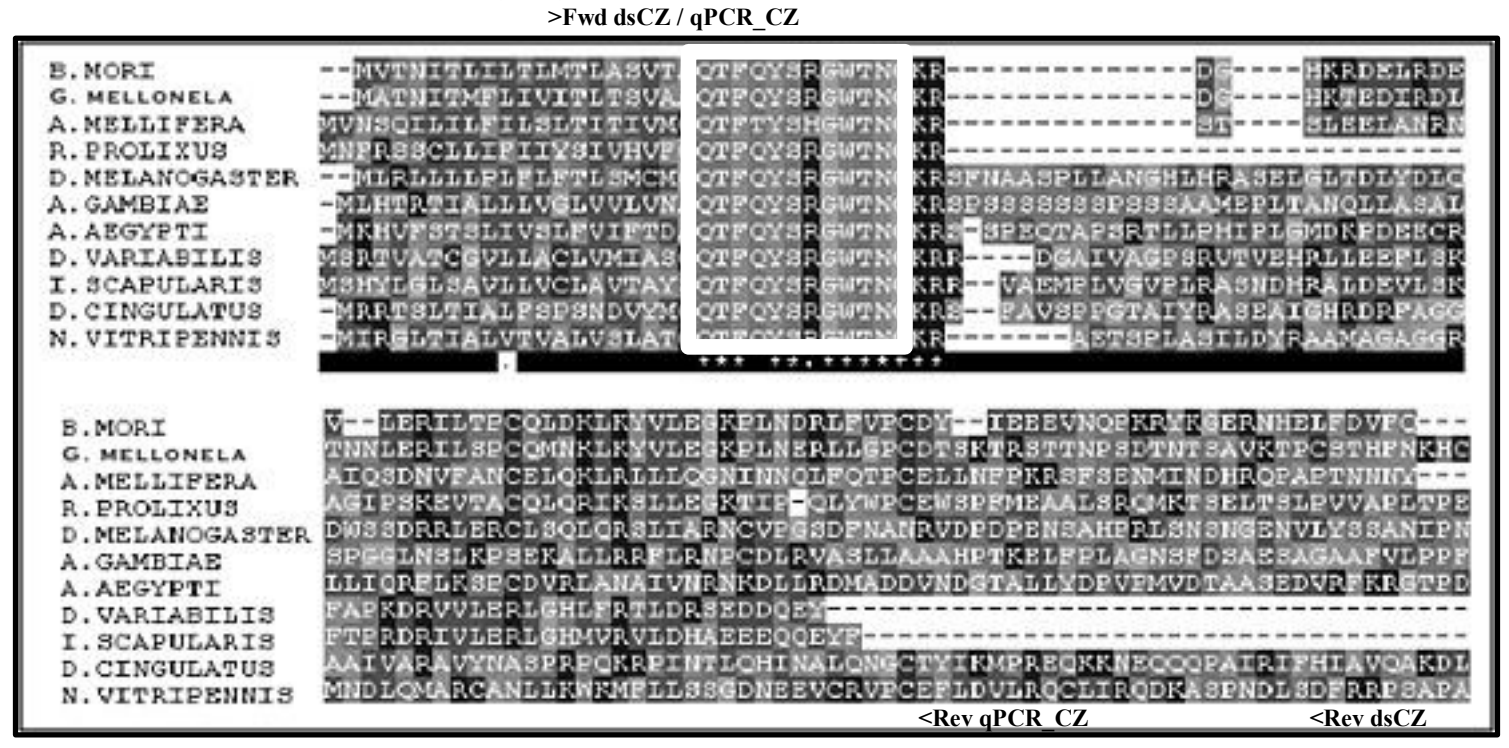

Figura 7: Secuencia aminoacídica del neuropéptido Corazonina en diferentes insectos (Ons, Richter et al. 2009; Sterkel 2011) y ubicación de los primers utilizados. Se encuentra recuadrado en blanco la secuencia aminoacídica del péptido maduro cuya secuencia es la más conservada entre distintos insectos. 

$>$ Fwd dsCCAP >Fwd qPCR_CCAP

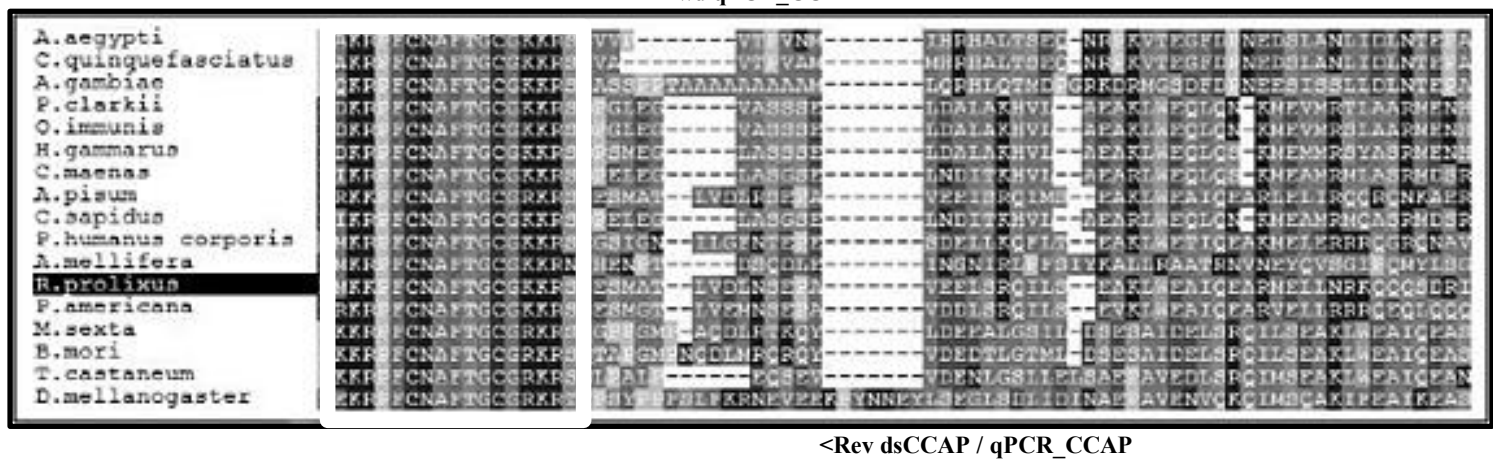

Figura 8: Secuencia aminoacídica del neuropéptido cardio acelerador de los crustáceos en diferentes insectos (Ons, Richter et al. 2009; Sterkel 2011) y ubicación de los primers utilizados. Se encuentra recuadrado en blanco la secuencia aminoacídica del péptido maduro cuya secuencia es la más conservada entre distintos insectos.

\section{Comprobación del silenciamiento transcripcional (caída de transcripto)}

\subsection{Testeo del silenciamiento transcripcional del gen Orcokinina}

Con el fin de confirmar el correcto silenciamiento transcripcional, en cada ensayo se midió la expresión de los transcriptos en todas las condiciones experimentales ensayadas. En todos los casos se obtuvieron diferencias significativas en la expresión de los genes silenciados en relación al grupo control (Figs. 9 A-H, 10 y 11 A, B y C).

Se utilizaron como referencia los genes RhoprTub y RhoprEF. 
RhoprokA

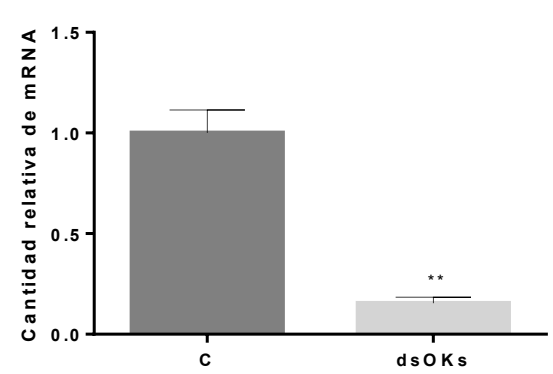

RhoprOKA

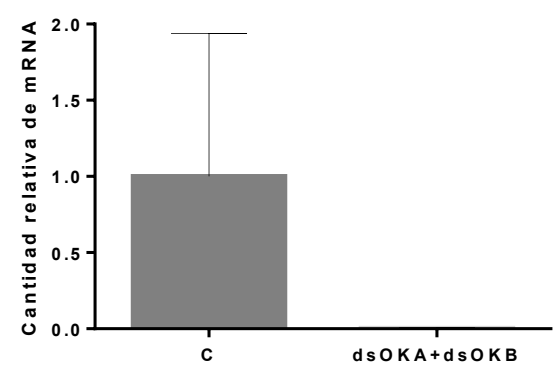

RhoprokA

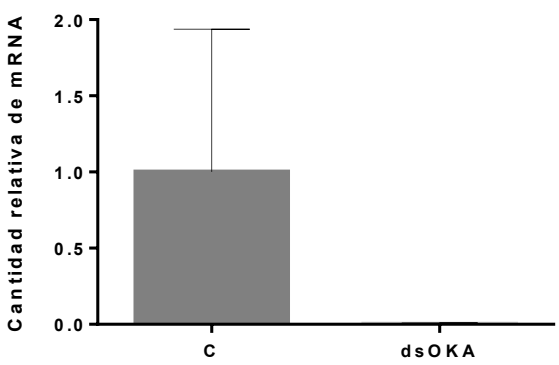

RhoprokA

G

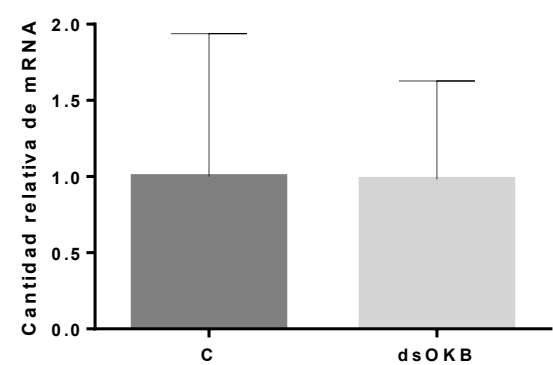

A

C

E
RhoproKB

B

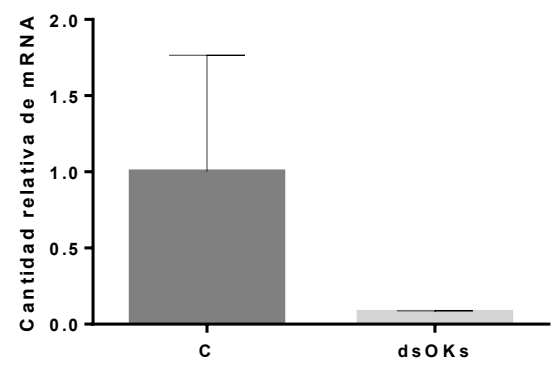

RhoprokB

D

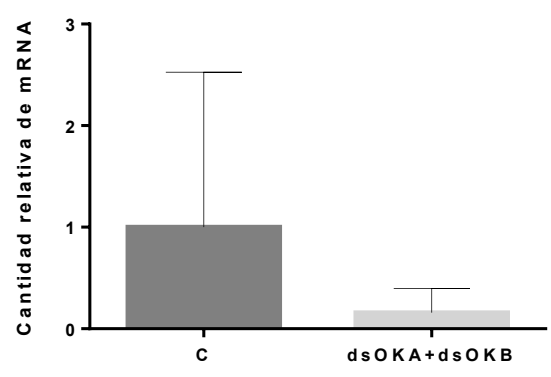

RhoprokB

F

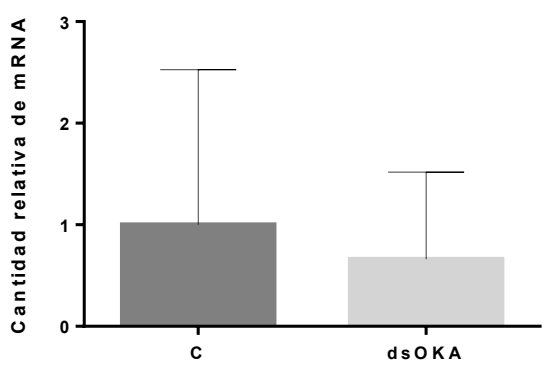

RhoproKB

H

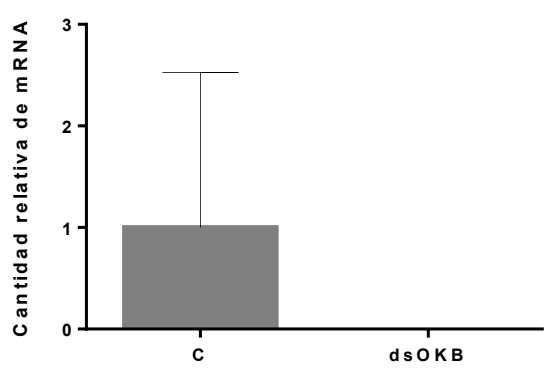

Figura 9: Medición de la expresión a nivel de transcripto total en ninfas de $4^{\text {to }}$ estadio 11 días PMB, en insectos silenciados (dsOKs, dsOKA y dsOKB) y no silenciados para el gen de Orcokinina. (A) RhoprOKA en presencia de dsOKs (B) RhoprOKB/C en presencia de dsOKs. (C) RhoprOKA en presencia de dsOKA + dsOKB/C. (D) RhoprOKB en presencia de dsOKA+dsOKB. (E) RhoprOKA en presencia de dsOKA. (F) RhoprOKB en presencia de dsOKA $(G)$ RhoprOKA en presencia de dsOKB $(\mathrm{H})$ 
RhoprOKB en presencia de dsOKB. Se realizaron entre 3 réplicas por día. Las barras de error indican SEM. Medido por ANOVA de 1 factor, diferencias estadísticamente significativas $(*=\mathrm{p}<0,05)$.

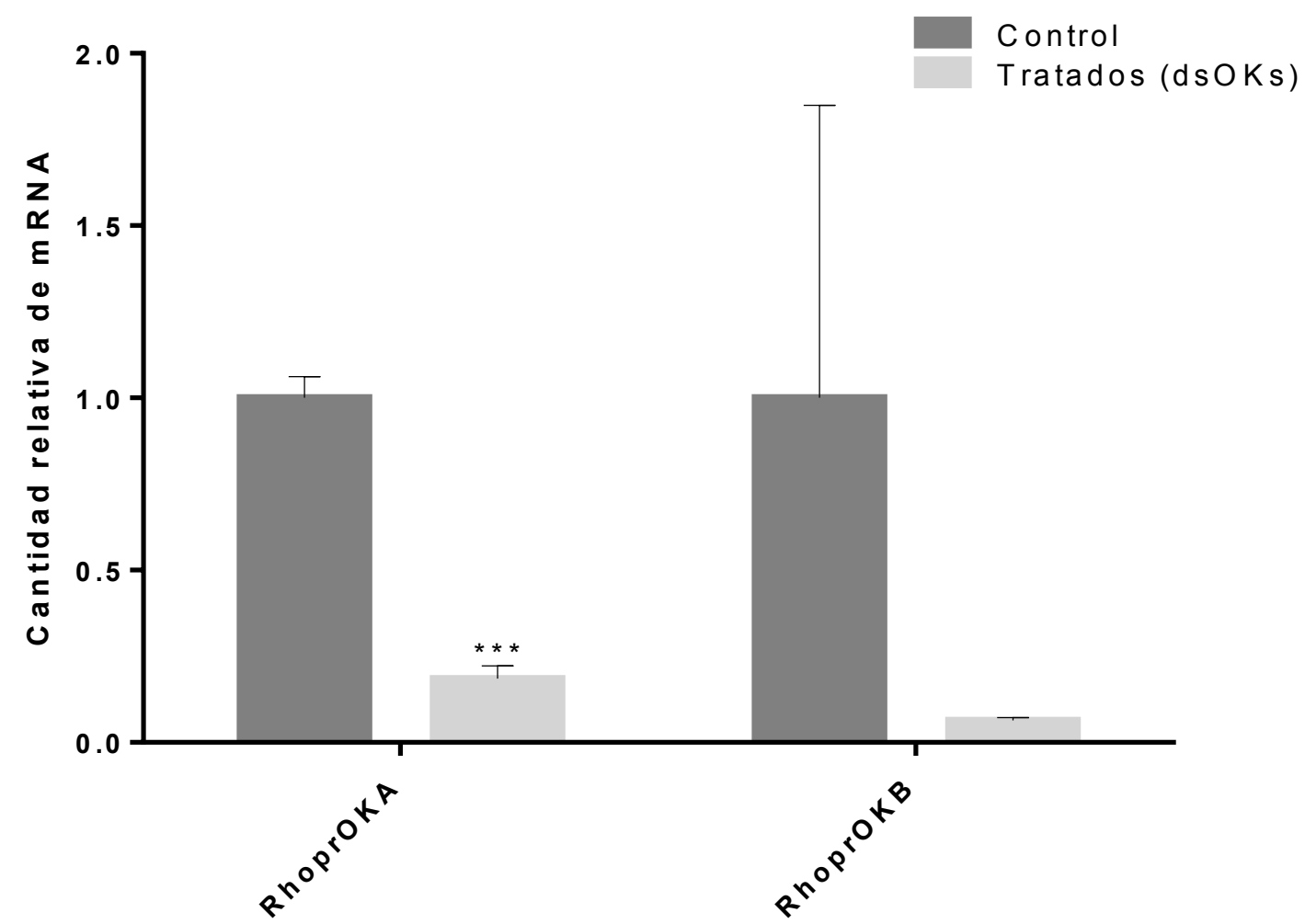

Figura 10: Medición de la expresión a nivel de transcripto total en ninfas de $5^{\text {to }}$ estadio 11 días PMB, en insectos silenciados (dsOKs) y no silenciados para el gen de orcokinina. Se realizaron entre 3 réplicas por día. Las barras de error indican SEM. Medido por ANOVA de 1 factor, diferencias estadísticamente significativas $(* * *=\mathrm{p}<0,001)$. 


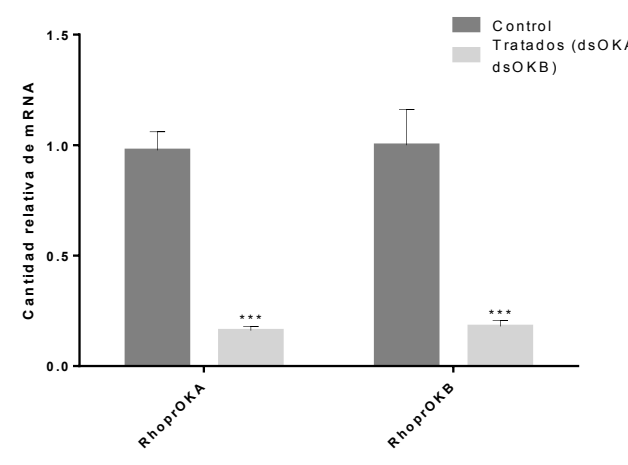

A

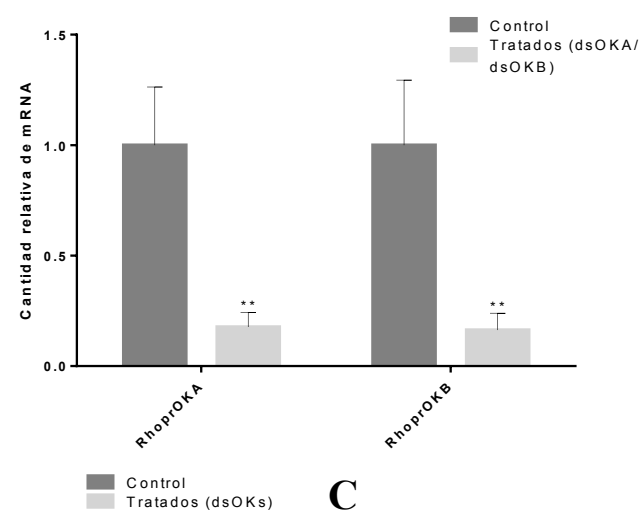

B

Figura 11: Medición de la expresión a nivel de transcripto total en ninfas de $4^{\text {to }}$ estadio días 6 (A) y 11 PMB (B y C). (A y B) Se midió la expresión de los transcriptos de RhoprOKA y RhoprOKB, en insectos silenciados particularmente para la isoforma testeada en cada caso (dsOKA o dsOKB), en los días 6 (A) y 11 PBM (B). (C) Se midió la expresión de los transcriptos de RhoprOKA y RhoprOKB en insectos silenciados para todas las isoformas de orcokinina (dsOKs) en el día 11 PBM. Se realizaron entre 4 réplicas por día. Las barras de error indican SEM. Medido por ANOVA de 1 factor, diferencias estadísticamente significativas $(*=\mathrm{p}<0,05 ; * *=\mathrm{p}<0,01 ; * * *=\mathrm{p}<0,001)$.

\subsection{Testeo del silenciamiento transcripcional de los neuropéptidos ETH, EH y CZ}

Con el fin de confirmar el correcto silenciamiento transcripcional, se midió la expresión de los transcriptos en cada caso, en los días en los cuales se realizaron los ensayos. En todos los casos se obtuvieron diferencias significativas en la expresión de los genes silenciados en relación al grupo control (Fig.2.26 A y B).

Se utilizaron como referencia los genes RhoprTub y RhoprEF. 

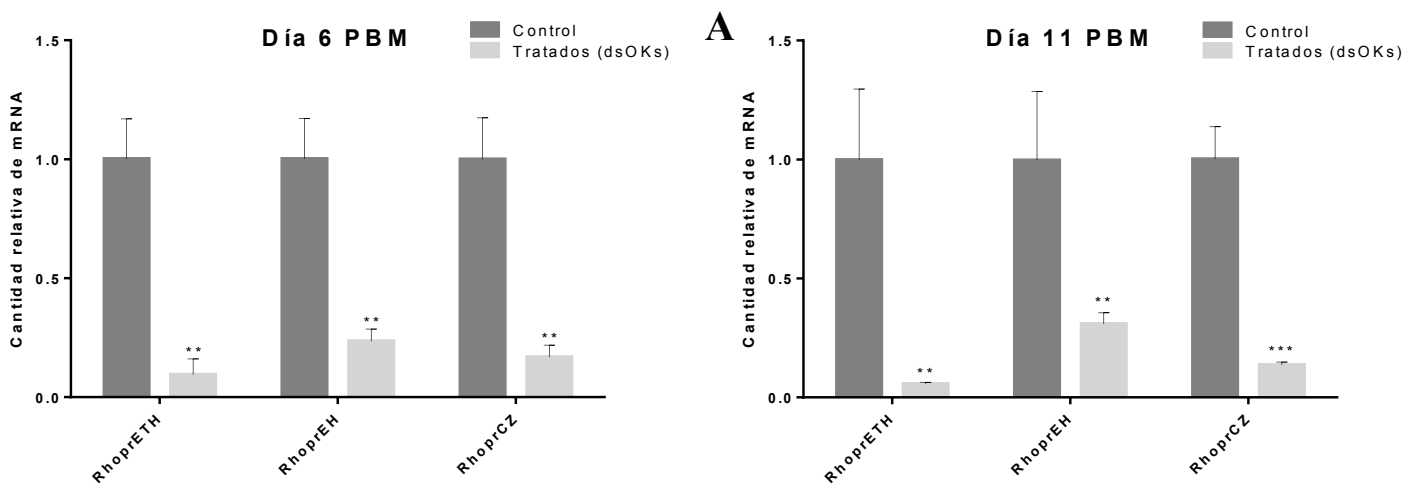

B

Figura 12: Medición de la expresión a nivel de transcripto total de las hormonas asociadas a la muda (RhoprETH, RhoprEH y RhoprCZ), en ninfas de $4^{\text {to }}$ estadio días 6 (A) y 11 PMB (B). (A) Se midió la expresión de los transcriptos en insectos silenciados particularmente para la isoforma testeada en cada caso (dsETH, dsEH o dsCZ), en el día 6 PBM. (B) Se midió la expresión de los transcriptos en insectos silenciados particularmente para la isoforma testeada en cada caso (dsETH, dsEH o dsCZ), en el día 11 PBM. Se realizaron entre 4 réplicas por día. Las barras de error indican SEM. Medido por ANOVA de 1 factor, diferencias estadísticamente significativas $(*=\mathrm{p}<0,05 ; * *=\mathrm{p}<0,01 ; * * *=\mathrm{p}<0,001)$.

\section{Soluciones}

\subsection{Buffer TBE 3X (Buffer de siembra)}

- Preparar solución EDTA 0,5M: disolver 93,5grs de EDTA en 200mL de agua bi-destilada, llevar a PH 8 con $\mathrm{NaOH}$ y ajustar a 500mLs de volumen final.

- Disolver 32,4grs de Tris y 16.5 grs de Ácido Bórico en $800 \mathrm{~mL}$ de agua bidestilada.

- Agregar 12mLs de 0,5M EDTA-Na PH 8.

- Ajustar volumen a $1000 \mathrm{~mL}$.

- Ajustar a concentración de trabajo diluyendo 1:3 y guardar a temperatura ambiente. 